\title{
A legal and empirical investigation into the direct selling industry's advocacy in the EU
}

Citation for published version (APA):

Tokaji-Nagy, O. (2016). A legal and empirical investigation into the direct selling industry's advocacy in the EU. [Doctoral Thesis, Maastricht University]. Maastricht University. https://doi.org/10.26481/dis.20160120ot

Document status and date:

Published: 02/01/2016

DOI:

$10.26481 /$ dis.20160120ot

Document Version:

Publisher's PDF, also known as Version of record

\section{Please check the document version of this publication:}

- A submitted manuscript is the version of the article upon submission and before peer-review. There can be important differences between the submitted version and the official published version of record.

People interested in the research are advised to contact the author for the final version of the publication, or visit the DOI to the publisher's website.

- The final author version and the galley proof are versions of the publication after peer review.

- The final published version features the final layout of the paper including the volume, issue and page numbers.

Link to publication

\footnotetext{
General rights rights.

- You may freely distribute the URL identifying the publication in the public portal. please follow below link for the End User Agreement:

www.umlib.nl/taverne-license

Take down policy

If you believe that this document breaches copyright please contact us at:

repository@maastrichtuniversity.nl

providing details and we will investigate your claim.
}

Copyright and moral rights for the publications made accessible in the public portal are retained by the authors and/or other copyright owners and it is a condition of accessing publications that users recognise and abide by the legal requirements associated with these

- Users may download and print one copy of any publication from the public portal for the purpose of private study or research.

- You may not further distribute the material or use it for any profit-making activity or commercial gain

If the publication is distributed under the terms of Article $25 \mathrm{fa}$ of the Dutch Copyright Act, indicated by the "Taverne" license above, 
A Legal and Empirical Investigation into the Direct Selling Industry's Advocacy in the EU

Orsolya Tokaji-Nagy 
(c) Copyright O.J. Tokaji-Nagy

Production print Datawyse | Univeritaire Pers Maastricht

ISBN 9789461595232 


\title{
A Legal and Empirical Investigation Into the Direct Selling Industry's Advocacy in the EU
}

\author{
DISSERTATION \\ to obtain the degree of Doctor at the Maastricht University, \\ on the authority of the Rector Magnificus, \\ Prof. Dr. L.L.G. Soete \\ in accordance with the decision of the Board of Deans, \\ to be defended in public \\ on Wednesday 20 January 2016 at 14.00 hours. \\ by \\ Orsolya Judit Tokaji-Nagy, LL.M.
}

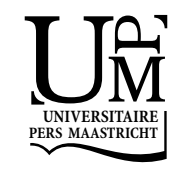




\section{Supervisor:}

Prof. Dr. J.M. Smits

Assessment Committee:

Prof. Dr. M.G. Faure (Chairman)

Dr. C.A.N.M.Y. Cauffman

Prof. Dr. C. Mak (Universiteit van Amsterdam)

Prof. Dr. Jac. Rinkes (Open Universiteit Heerlen) 


\section{Table of Contents}

$\begin{array}{lr}\text { Acknowledgements } & 9\end{array}$

1 Introduction 11

$\begin{array}{ll}1.1 \text { Introduction } & 13\end{array}$

$\begin{array}{ll}1.2 \text { Background to the Study } & 14\end{array}$

1.2.1 Direct Selling as a Channel of Retail 14

1.2.2 Background to the Industry Lobby 23

1.2.3 Background to Legislation and Self-Regulation 24

1.3 Academic and Practical Relevance of the Study 29

1.4 Objectives of the Study and Research Questions 30

1.5 Research Methodology 34

1.6 Structure of the Study 36

2 A Legal Overview 39

2.1 Introduction $\quad 41$

2.2 Consumer Law for Direct Selling $\quad 44$

2.2.1 The Doorstep Selling Directive 44

2.2.2 The Consumer Rights Directive 51

2.3 Fair Trading Law and Direct Selling $\quad 65$

2.3.1 Fair Trading Law in Business-to-Consumer Relations: the Unfair Commercial Practices Directive $\quad 65$

2.3.2 Marketing Law in Business-to-Business Relations: the Misleading and Comparative Advertising Directive $\quad 77$

$\begin{array}{ll}2.4 \text { Conclusions } & 84\end{array}$ 
3 Dossier 1: The Consumer Rights Directive and the Direct Selling Industry Lobby 87

3.1 Introduction

3.2 The Political Context: the Rocky Road to the Adoption of the Consumer Rights

Directive

3.3 Priorities for the Direct Selling Industry Concerning the Revision of Consumer Law

3.3.1 Maximum Harmonisation

3.3.2 Scope of Application and Exemptions 96

3.3.3 Information Requirements

104

3.3.4 Withdrawal Right 106

3.3.5 Bans on Payments and Bans on Sales 108

3.3.6 Direct Selling Represents 'Positive Values' 118

3.4 Evaluation of the Industry Lobby's Impact on the Consumer Rights Directive 118

3.4.1 Evaluation from the Perspective of Substantial Law 119

3.4.2 Evaluation of Lobbying Techniques 123

3.5 Conclusion 125

4 Dossier 2 The Pyramid Scheme Definition 127

4.1 Introduction 129

4.2 Competing Regulatory Concepts 130

4.2.1 The Pyramid Scheme Concept of the VIEW Final Report 130

4.2.2 The Direct Selling Industry's Position 136

$\begin{array}{ll}4.3 \text { Evaluation } & 145\end{array}$

4.3.1 Interpretation of the Legislative Output 145

$\begin{array}{ll}\text { 4.3.2 Evaluation } & 149\end{array}$

$\begin{array}{ll}4.4 \text { Conclusion } & 155\end{array}$

5 Dossier 3: Self-Regulation 157

5.1 Introduction $\quad 159$

5.2 European Codes of Conduct for Direct Selling 159

5.2.1 Codes of Conduct Towards Consumers 160

5.2.2 Codes of Conduct Towards Direct Sellers and Companies 163

5.2.3 Private Enforcement 165

5.3 Motives of Self-Regulation $\quad 168$

5.4 Industry Self-Regulation as an Agent of European Harmonisation $\quad 175$

$\begin{array}{ll}5.5 \text { Conclusion } & 179\end{array}$ 
6 Dossier 4: Entrepreneurship Promotion

6.1 Introduction

6.2 The European Entrepreneurship Policy

6.3 Entrepreneurship as a Lobbying Dossier

6.3.1 Redefinition of the Industry Image

6.3.2 Funding Entrepreneurship Research

6.3.3 Championing in Women Entrepreneurship (Advocacy)

7 Strategies and Techniques of Direct Selling Interest Representation

7.2 Research Method and Constraints

7.3 Theoretical Framework

7.3.1 The Public Choice Theory and Lobbyism

7.3.2 Group Size Theory and Collective Action

7.3.3 The Access Theory

7.4 Empirical Data of Direct Selling Advocacy Methods in the EU

7.4.1 Trade Associations

7.4.2 National Direct Selling Trade Associations

7.4.3 Corporate Lobbying

7.5 Discussion of Empirical Findings

7.5.1 Direct Selling Advocacy as a Rational Choice

7.5.2 Collective Action, Group Size Theory and Individual Lobbying of Direct Selling Advocates

7.5.3 The Direct Selling Industry's Access to Political Institutions

7.5.4 Litigation Strategies

8 Summary of Findings $\quad 285$

$\begin{array}{ll}8.1 \text { Introduction } & 287\end{array}$

8.2 Preliminary Remarks and the Legal Background 288

8.3 Strategic Industry Interests and Industry Advocacy 290

$\begin{array}{ll}8.4 \text { Lobbying Techniques } & 301\end{array}$ 
Valorisation Addendum

Annex I European Direct Selling Trade Association Representatives' Interview Questions

Annex II Questionnaire for Direct Selling Associations on Direct Selling Industry Lobbying in the European Union

Annex III Corporate lobbying Strategies Of Multinational Companies in the Field of Direct Selling Questionnaire

Bibliography 


\section{Acknowledgements}

Words cannot express my gratitude to my Ph.D. supervisor, Professor Jan M. Smits for his support in these past two years. Professor Smits is a wonderful teacher who provided me not only with invaluable guidance and expertise throughout the entire research project but has also given me the freedom to do what I deemed was right, helping me with his constructive contributions and feedback every step of the way. I am especially thankful for Jan's support in the times when there were bumps in the road and I was in need of direction. I am deeply honoured to have had the opportunity to work with Jan who has most certainly been the best supervisor I could ever imagine.

I will forever be thankful to my esteemed colleagues from the direct selling industry who have contributed to this research. I would like to express my heartfelt thanks to Oscar Cano Arias, Maurits Bruggink, Paul Dobson, Paul Gagnier, Janne Heimonen, Jens Karsten, Marie Lacroix, Simon Levitt, Hakki Ozmorali, the public affairs managers of "Pinkify", "SuperFit" and "SweetScent" who wished to remain anonymous as well as the representatives of the national direct selling associations who contributed to the present study. If it was not for these people and their expert input, I could not have written this dissertation.

I would especially like to thank those dear friends who have believed in this endeavour and have supported me throughout. I am truly grateful to Patrick Ahern, Gyorgyi Constantinovits, Szandra Deutsch and Jaroslaw Mulewicz for all their kindness and faith in me.

I also thank my family for supporting me in every way possible and exemplifying commitment and determination to achieve my goals. Their contributions to my life will be felt forever.

Finally, a special thanks to a special person, Ricardo, for standing by me, encouraging me and being my sunshine day and night. 



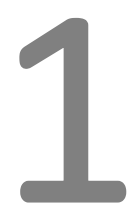

Introduction 



\subsection{Introduction}

This is a study of direct selling industry lobbying in the European Union - a research that intends to shed light on the perhaps less visible strategies and modes of interest representation of a highly controversial industry in the Brussels political arena. The aim is to provide an overview and a thorough understanding of the strategic goals of the direct selling industry in terms of policymaking, the extent to which the direct selling industry lobby influences European private law, and, lastly, what lobbying strategies are applied by this particular interest group.

There are two reasons why the present research is important. Firstly, the study assesses how the direct selling industry has asserted influence upon European legislation, i.e. what the concrete impact of the industry advocacy was on EU consumer-, commercial- and unfair competition law, and assesses the industry's contribution to the shaping of European law. An intriguing feature in this respect is the vicious cycle the industry lobby has appeared to be caught up in, whereby the idiosyncrasies and controversies of the distribution method seem to frequently result in the adoption of stringent legislation which in turn compels the industry lobby to constantly battle its own negative reputation, trying to reduce the political risk of government intervention or at least attempting to mitigate the legislative response to the adversities and abuse of the sales channel.

The second novelty is the comprehensive examination of the direct selling industry's advocacy actors in Brussels that attempts to establish the main lobbying patterns and institutional access of this interest group in the framework of the pluralistic political system or "lobbying democracy".

The research thus takes place at the intersection of European law and political sciences where the goal is to observe and analyse, through legal research, in what way the direct selling industry prefers to influence the substance of EU law to best serve the industry's private interests, as well as to provide empirical evidence of lobbying strategies and techniques through which the industry strives to advocate its position towards EU institutions.

For this purpose, key legislative goals of direct selling lobbying are identified and analysed in the study, highlighting the interests behind the industry position and proposed legislation. The interplay between the advocated legislative outcome and the actual output, the degree to which legislative goals are met and the quality of the resulting norms has been subject to scrutiny in the course of the examination of four lobbying dossiers. Stepping over to the terrain of political sciences, political strategies and the direct selling industry's lobby groups' access to European institutions are described in the second main part of the thesis. 


\subsection{Background to the Study}

\subsubsection{Direct Selling as a Channel of Retail}

Direct selling is one of the three main distribution channels alongside in-store retail and distance selling and can be conceptualised as the obtainment of orders and the supply of consumer products (goods and services) to private individuals away from normal retail premises, usually in their homes or places of work, in transactions initiated and/or concluded by a salesperson. ${ }^{1}$

The present sub-section aims to introduce the direct selling industry in more detail, highlighting its economic importance, its main characteristics in terms of structure, operation and marketing methods, and the main advantages and disadvantages of the channel. All of the described dimensions bear high relevance for the overall enquiry concerning the direct selling industry's advocacy: while information on the industry's economic weight indicates the degree of pressure it can exert on policymakers, the introduction of key characteristics of the sales method and the various means of abuse thereof allow the reader to better understand contemporaneous direct selling legislation and the directions in which the industry lobby intends to influence policymakers.

Based on the statistics provided by Seldia, the European Direct Selling Association ${ }^{2}$, it is estimated that direct selling retail in the EU produced EUR18.768 million (excl. VAT) in 2013 by over 5.18 million direct sellers. The largest market in the EU is Germany (EUR6.3bn), followed by France (EUR4bn), the UK (EUR2.5bn), Italy (EUR2.3bn) and Poland (EUR0.6bn). ${ }^{3}$ In comparison, the European online revenue of goods and services reached EUR311.6 billion in 2012, whereas the EU-27 has produced EUR 2.35 trillion in the same year. ${ }^{4}$

\footnotetext{
${ }^{1}$ The definition was conceptualised by Richard Berry in 1997 and was later adopted by Brodie et al. in 2004 in Public Perceptions of Direct Selling: An International Perspective - Westminster Business School Research Report 2004 (Westminster University Press, Westminster, 2004), p. 3.

${ }^{2}$ Seldia is one of the two European direct selling associations. The other European federation is Direct Selling Europe.

${ }^{3}$ The information has been taken from the Seldia website at http://www.seldia.eu/images/pdf/2013_stat_ general_presentation31072014.pdf (last visited 17 September 2014)

${ }^{4}$ European Shopping Centre Trust: Key European Retail Data - 2012 review and 2013 forecast (April 2013), http://www.deutsche-

euroshop.de/media/public/db/media/1/2011/12/199/201305_esct_key_european_retail_data.pdf (last visited 17 September 2014), p.6.
} 
According to the industry data ${ }^{5}$ provided by the World Federation of Direct Selling Associations, regionally, Asia/the Pacific produced 43\%, the Americas 38\%, Europe 18\% and Africa and the Middle East $1 \%$ of global sales in $2013 .^{6}$

Direct selling is conducted by direct selling companies' direct sellers, mainly selfemployed, part-time, independent contractors. These independent contractors usually trade under the "banner" or the logo of a greater enterprise. The well-known large corporations, such as AVON Cosmetics, Amway, Herbalife or Tupperware are the leading direct selling multinational companies producing billions of dollars in net sales annually. ${ }^{7}$ Direct selling offers a business opportunity with low entry barriers, personal skills development and the possibility of making immediate income. Offering income opportunities and an alternative to employment even to those with lower skills is the reason why direct selling excels in poor economic conditions and is deemed recession-resilient or counter-cyclic in its nature.

Direct selling companies apply either "person-to-person" or "party-plan" sales methods. The "person-to-person" method involves the explanation and demonstration of a product in the consumers' homes or workplaces, on an individual basis. It also includes the provision of a catalogue to the potential consumer in order for the customer to see the entire product range before placing an order. "Party-plans" are demonstrations held by the direct seller to a group of people at the home of a consumer who acts as, and is rewarded by the direct seller for being, the host. ${ }^{8}$

Based on the compensation of the companies' independent contractors, the organisation of direct selling firms can be distinguished either as "single-level marketing" or "multi-level marketing" companies.

Single-level companies offer direct sellers the opportunity to make retail profit by selling products to consumers on a person-to-person basis or through a party-plan. Recruitment and training of new participants is usually carried out by managers appointed by the company, who may or may not be self-employed and may or may not be involved in making personal sales.

\footnotetext{
${ }^{5}$ It must be noted at the offset that the statistics provided by the direct selling industry is not representative: direct selling as a commercial activity does not have a separate statistical number in many Member States, wherefore the exact size of the sector cannot be reported. The World Federation of Direct Selling Associations does collect data annually, however, the data is obtained from and through the member associations; thus, the segments of the industry falling outside of the World Federation membership is not necessarily featured in the statistics accurately.

6 WFDSA, 'Global Direct Selling - 2013 Retail sales', 2013, http://www.wfdsa.org/files/pdf/globalstats/Sales_Report_2013.pdf (last visited 17 September 2014)

${ }^{7}$ Brodie et al., Public Perceptions of Direct Selling: An International Perspective, p. 4.

${ }^{8}$ Ibid., p. 4.
} 
In a multi-level marketing (MLM) company, the new participant is immediately offered the opportunity of benefiting not only from their personal sales, which again may be person-to-person or party sales, but also from the sales of those they may recruit, directly and indirectly, into the business. They will be paid override commissions and bonuses based on the acceptance of their ongoing responsibility to train and motivate these recruits. $^{9}$

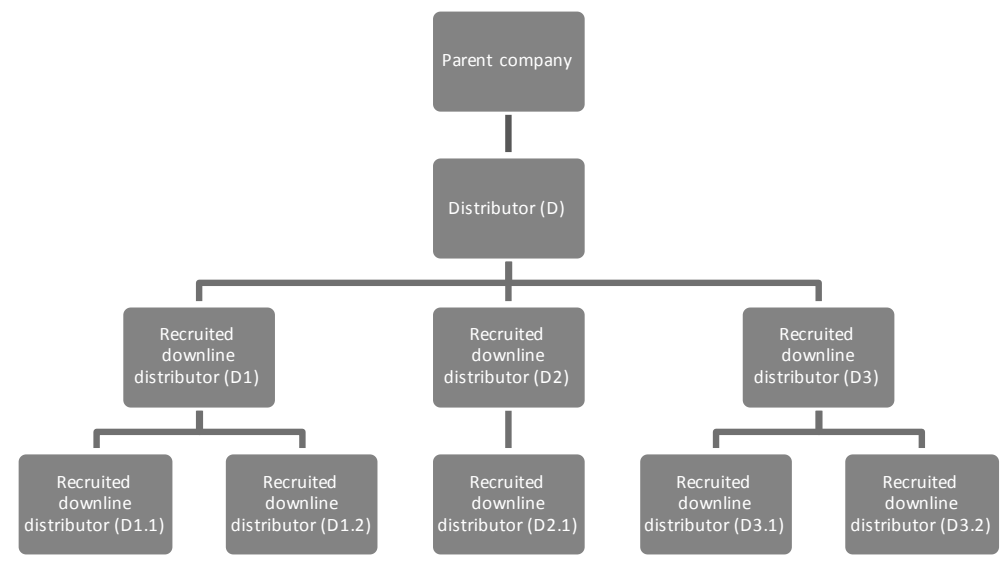

\section{A Multi-Level Marketing Structure}

In this system $\mathrm{D}$ benefits from his own sales as well as the overrides from the sales of his recruits D1, D2 and D3 and the groups of D1 (D1.1 and D1.2), D2 (D2.1) and D3 (D3.1 and D3.2). D1 benefits from his own sales and the overrides from his group, D1.1 and D1.2, D2 benefits from his own sales and the overrides from D2.1 whereas D3 benefits from his own sales and the over-rides from D3.1 and D3.2.

All distributors in the MLM model (just as in the single level marketing model) are businesses, forming a B2B contractual relationship with the parent company (not their recruiters). To continue with the example, $\mathrm{D}$ is in a contractual relationship with the Parent Company and so are D1, D2, D3, D1.1, D1.2, D2.1, D3.1 and D3.2.

The most popular products sold through the direct selling channel are cosmetics and personal care, wellness products, household goods and durables, clothes and accessories, books, toys, stationary and home care items.

Direct selling, like any retail channel, has its advantages and disadvantages. In order to fully comprehend the strategic interests and political strategies of direct selling busi-

\footnotetext{
${ }^{9}$ Ibid., p. 4.
} 
ness lobbying, an elementary understanding of the industry, including its benefits and controversies, must be developed.

Direct selling is one of the most archaic forms of retail: hawkers, peddlers, traders, itinerant merchants and caravans are all part of an ancient tradition that originated in man's basic need to exchange goods and to communicate. While nearly every culture shares a heritage of direct selling in the historical sense, development of the retail channel took on a new level in the 1950s United States with the advent of home selling parties and the appearance of multi-level marketing, offering opportunities also to those who had previously run into barriers because of their level of education, age or gender. In the 21 st century, customers still benefit from this retail channel which in the meantime has integrated the use of the internet into its sales methods, essentially providing every direct seller a worldwide customer base. ${ }^{10}$

Direct selling offers the comfort of in-home buying, facilitating for consumers access to goods they may otherwise not be able to acquire in the event that they reside in rural areas underserved by other retail channels or are elderly and/or house-bound. ${ }^{11}$

Furthermore, direct sellers often offer a more detailed demonstration and description of the product than representatives of other retail channels, usually combining the product demonstration with the possibility to try the product before the purchase. ${ }^{12}$

As a retail channel rooted in the notion of entrepreneurship, direct selling has a number of advantages and socio-economic benefits to offer to those seeking a business opportunity as well. Flexible work schedule, low entry barriers and a simplified business model combined with skills training in general offers an alternative to employment, and/or the possibility of (re-)integration into the job market, which may be particularly beneficial for underrepresented demographic groups in business life such as seniors, migrants or women, as well as for those with a low level of education. The overwhelming majority of direct sellers are women (in the EU 78\% of direct sellers ${ }^{13}$ ) and a similarly large segment of the distributors work part-time, providing extra income for families and allowing women to create a work-family balance.

However, direct selling is subject to frequent criticism due to a high number of consumer- and direct seller grievances that disturb the advantages of the direct selling

\footnotetext{
${ }^{10}$ Direct Selling 411, 'History of Direct Selling', http://www.directselling411.com/about-direct-selling/historyof-direct-selling/ (last visited 17 September 2014)

${ }^{11}$ Jolson, M. A., 'Direct Selling: Consumer vs. Salesman - Is Conflict Inevitable?', 15 Business Horizon, Issue 5 (October 1972), p. 87-95., p. 90.

${ }^{12}$ Ibid., p. 89.

13 Seldia website, 'Statistics', http://www.seldia.eu/images/pdf/2013_stat_general_presentation31072014.pdf (last visited 17 September 2014)
} 
channel. Based on the thorough assessment of existing literature - especially Jolson ${ }^{14}$ and the author's own professional experience, the main disadvantages and abuses of the sales channel, in my view, are as follows.

In terms of consumer grievances, a frequent complaint is that the direct selling sales method upsets the consumer's rational planning, schedule and purposes with the consumers being - at times aggressively - pressured into transactions by direct sellers to purchase goods they do not need. ${ }^{15}$ This is a clear example of a consumer lacking psychological strength whereby the consumer may find it hard to resist to enter into a transaction that was either offered to him by surprise and/or is forced upon him - as opposed to consumers' lack of informational strength (i.e. information on the product) which appears to be more typical for distance selling, points out Jan Smits. ${ }^{16}$ Similarly, Omri Ben-Shahar and Eric A. Posner see the danger of aggressive practices in doorstep selling transactions or telemarketing as longstanding concerns "in which consumers are vulnerable to 'seduction'." ${ }^{17}$ It is these concerns, say the authors, that are the main justification for mandatory statutory rights of withdrawal that allow the consumer to withdraw from a legally-binding contract. This factor is exemplified by the practice that some distributors refuse to leave the consumer's home upon request, putting additional pressure on consumers to conclude the sales contract. ${ }^{18}$

Another aspect of applying pressure has been detected in case of network (MLM) marketing, where much of the criticism points to the exploitation of social networks the pressure friends and family feel to purchase unwanted or unnecessary products because the salesperson is close to them. ${ }^{19}$

Although direct selling firms usually train their sales force to make correct statements of products, in an effort to achieve more sales and increased commission, some distributors intentionally mislead the prospective consumer by making false claims about the goods, for instance by falsely stating that a food supplement has healing effect.

A further consumer grievance is that the transactions concern the sale of items that are either fixed and/or are significantly overpriced to cover the commission of the sales

\footnotetext{
${ }^{14}$ Jolson, M. A., 'Direct Selling: Consumer vs. Salesman - Is Conflict Inevitable?', 15 Business Horizon, Issue 5 (October 1972)

${ }^{15}$ Ibid. p., 88.

${ }^{16}$ Smits, J. M., 'Rethinking the Usefulness of Mandatory Rights of Withdrawal in Consumer Contract Law: The Right to Change Your Mind', 29 Penn St. Int'l L. Rev. 671 (2010-2011), p. 672-683, p. 678.

${ }^{17}$ Ben-Shahar, O. and Posner, E. A., 'The Right to Withdraw in Contract Law', 40 Journal of Legal Studies, Issue 1, Article 4 (January 2011), p. 115-148, p. 120.

${ }^{18}$ Jolson, M. A., 15 Business Horizon, Issue 5, (October 1972) p. 88.

${ }^{19}$ Oksanen-Ylikoski, E., Businesswomen, Dabblers, Revivalists or Conmen? - Representation of Direct Selling and Salespeople within Academic, Network Marketing Practitioner and Media Discourses, p. 12.
} 
persons, the latter being an even greater problem if older people with a low level of income are being pressured into the transaction.

Distributors, on the other hand, also have to face a number of difficulties stemming from the nature of the sales channel.

Firstly, distributors may encounter a high level of rejection on three levels: when initiating the contact, in the course of the product demonstration or solicitation or, thirdly, after the purchase is made. ${ }^{20}$ The negative public perception of the industry often results in strong rejection, increasing the frustration of the distributors. ${ }^{21}$

In addition, there is no earning security for distributors. The income being dependent on the amount of sales (and the deriving commission), combined with the level of rejection may actually present a disconcerting situation for the sales person and, as a result, the possibly high turnover of manpower. ${ }^{22}$

As a consequence, distributors may relent to unethical techniques such as pressuring potential clients or making misleading claims. The consumer aspect of such pressure techniques has been described in detail above; what is important to highlight here is the application of pressure on members of the salesman's social network in order to motivate members of the social network to join the network marketing schemes, which may be particularly problematic. Instrumentalisation of the distributor's circle of acquaintances for purposes of promoting the multi-level marketing opportunity was found to be psychologically and socially unacceptable, for the most part, in western society. ${ }^{23}$

Another dimension of unethical recruitment techniques concerns misleading and excessive earnings representations made towards prospective distributors in a networkmarketing context. ${ }^{24}$ Excessive earnings claims lack factual backing and aim to deceive prospective distributors in order to encourage them to join the scheme, providing the recruiter extra income by building their downline and are often indications that the scheme is a pyramid. An area of key concern for the direct selling industry and law enforcement alike, the matter of misleading and deceptive earnings claims will be analysed in detail from a legal perspective in the subsequent chapter when discussing unfair trading practices (chapter II, Legal Overview, sub-section 2.3.1.5. for B2C misleading commercial practices and sub-section 2.3.2.3. for misleading advertising in a B2B context).

Besides false promises of getting rich quickly, some firms applying multi-level marketing techniques have attracted criticism for resembling cults because of their hierar-

\footnotetext{
${ }^{20}$ Jolson, M. A., 15 Business Horizon, Issue 5 (October 1972), p. 90.

${ }^{21}$ Ibid., p. 91.

${ }^{22}$ Ibid., p. 91.

${ }^{23}$ Bloch, B., 'Multilevel Marketing: What's the Catch?', 13 Journal of Consumer Marketing, Issue 4 (2006), p.18 -26 .

${ }^{24}$ Jolson, M. A., 15 Business Horizon, Issue 5 (October 1972), p. 91.
} 
chic structure led by charismatic figures and the indoctrination of participants to both keep as well as to increase membership and members' devotion. For example, the book Fake It 'Til You Make It: What Your Soap Distributor May not Have Told You ${ }^{25}$ by Phil Kerns, a former Amway distributor and cult member, compared Amway (now a leading American direct selling corporation applying a MLM marketing method) to the religious cult, the "People's Temple", a movement best known for its events of mass suicide in which 920 people died in November 1978 in Georgetown, Guyana. Based on the various characteristics utilised by the company to integrate salespeople and their resemblance to the methods used by the People's Temple, Kerns claims Amway could also be considered a cult. ${ }^{26}$

The most severe controversies, however, are connected to pyramid promotional schemes that cause grievances to consumers and distributors alike. Pyramid promotional schemes are seemingly endless, geometrically progressing promotions of distributorship, rather than the sale of goods and services where the false opportunity to get rich quickly and easily is offered to the investors. In a pyramid scheme, each time a member recruits a new participant to the network, he receives a cash sum deriving from the new entrant's membership fee. Entry fees of members are adjusted to the level of the pyramid at which the new participant enters: the higher the member, the greater the sum received. ${ }^{27}$ Eventually the number of new recruits fails to sustain the payment structure and the scheme collapses with most people losing the money they paid in. ${ }^{28}$

Certain schemes operate without a product, such as the classic pyramid scheme, the infamous "Airplane Game" from the 1970s and 1980s. The "Airplane Game" was based on a structure where the entrant paid USD1.500 to participate and, after filling the $2 \times 4$ matrix (two "co-pilots", four "crew members" and eight "passengers", or 14 total participants) they become a "pilot" and cashed out for USD10.000. ${ }^{29}$

\footnotetext{
${ }^{25}$ Kerns, P., Fake It 'Til You Make It: What Your Soap Distributor May Not Have told You, (Victory Press, Carlton, Or.,1982)

${ }^{26}$ Ibid., p. 57.

${ }^{27}$ Goldring, J., Maher, L., McKeough, J., Pearson, G., Consumer Protection Law, (5th edition, The Federation Press, Leichhardt, NSW, Australia, 1998), p. 295.

${ }^{28}$ Network Marketing Business School, 'Is Network Marketing a Pyramid Scheme?', http://www.networkmarketing-business-school.com/pyramid-scheme.html (last visited 17 September 2014)

${ }^{29}$ Clements, L., 'Ponzi \& Pyramid', MarketWave (2009), http://www.marketwaveinc.com/viewarticle.asp? id=72 (last visited 17 September 2014)
} 


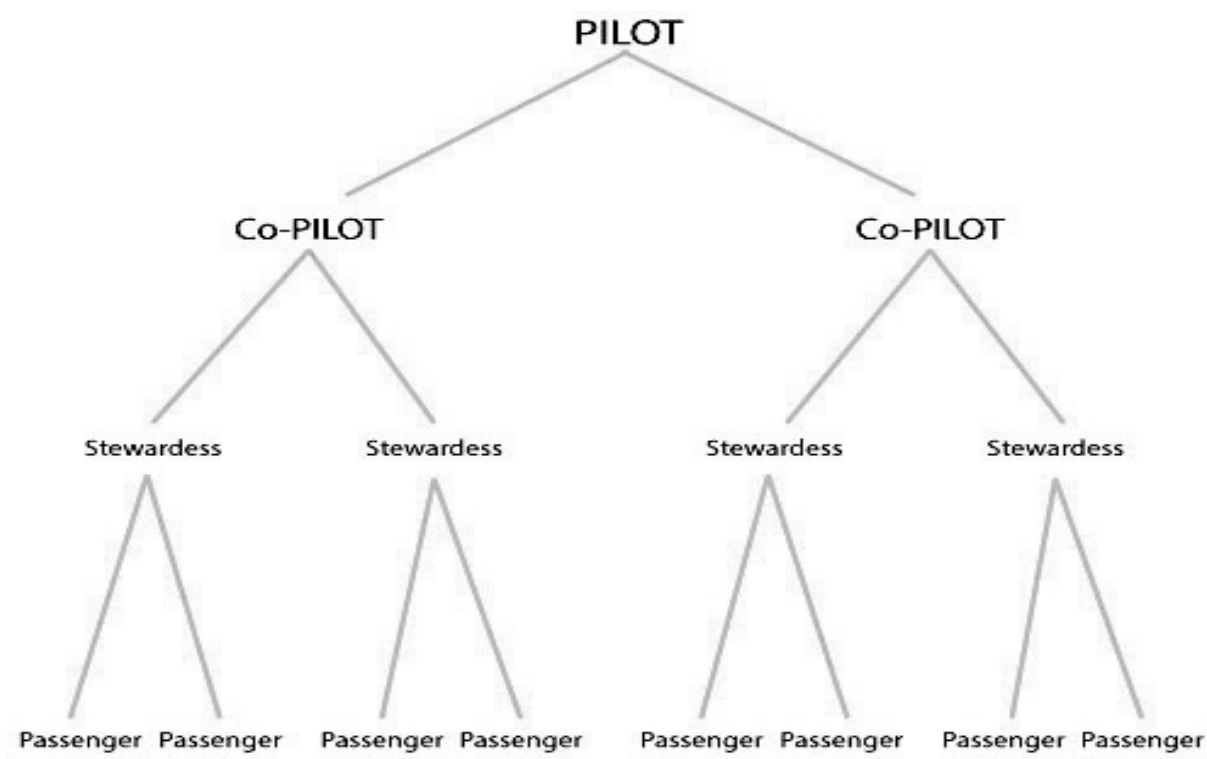

The image has been taken from Laggos, K., 'Matrices and Illegal Pyramid Schemes', Network Marketing Business Journal, December 2010 Issue, http://www.nmbj.com/ articles/archives/PubsPer/PP_December_2010.asp (last visited 17 September 2014)

As the absence of a product waives huge red flags for law enforcement, the vast majority of pyramid promotional schemes disguises itself as a legitimate MLM and offers a mere token product that is purchased only to meet a quota, or one that is of value only to a distributor. ${ }^{30}$ While specific details of operation differ from scheme to scheme, the two fundamental characteristics of pyramid promotional schemes are (1) the payment for the right to become a distributor and (2) the receipt of some reward or benefit for recruiting new distributors. ${ }^{31}$

Further major criticisms levelled at pyramid schemes and the reasons why legislation to outlaw these schemes was introduced in several countries are the following:

\footnotetext{
${ }^{30}$ Ibid.

${ }^{31}$ Goldring, J., Maher, L., McKeough, J., Pearson, G., Consumer Protection Law, p. 296.
} 
1. Pyramid schemes are fraudulent because:

a. the "get rich quickly and easily" claims are deceptive as they rely on distributors' belief in a seemingly unlimited scheme whereas the structure is unsustainable;

b. they are camouflaged as legitimate MLMs oriented towards the sale of actual products and services whereas they are concerned with the recruitment of distributorship;

c. they rely on the misrepresentation concerning the return on investment. ${ }^{32}$

2. Distributors frequently operate without exclusive territorial rights vis- $a$-vis their fellow distributors and certain territories are frequently saturated. ${ }^{33}$

3. Distributors at various levels inevitably pay high prices for products because of the several levels of distribution and a concomitant price discounting mechanism. ${ }^{34}$

4. Distributors are required to sign unconscionable distributorship contracts.

5. Distributors who have made an investment may often be pressured into additional expenditure to cover training courses, purchase significant inventory, storage or accounting requirements. Often, training courses are aimed at pressuring the distributor to increase his investment and to thereby move up in the levels of distribution. ${ }^{35}$

Despite all the positive aspects of direct selling, the afore described consumer- and sales force grievances have resulted in the stigmatisation and public condemnation of the industry, especially of the MLM system, often prompting restrictive or prohibitive responses from legislators. ${ }^{36}$ It is one of the main tasks of the direct selling industry's advocacy to try to fend off stringent legislative responses given to the discrepancies connected to the sales channel through a wide array of efforts ranging from selfregulation, the introduction of a system of private norms setting high trading standards for the direct selling industry, through legislative lobbying, to the execution of carefully designed PR campaigns aiming to better the overall image of the sales channel. Direct selling is therefore a rather challenging field to lobby for. However, as will be described

\footnotetext{
${ }^{32}$ Ibid., p. 296.

${ }^{33}$ Ibid., p. 296.

${ }^{34}$ Ibid., p. 296.

${ }^{35}$ Ibid., p. 297.

${ }^{36}$ See already Jolson, M. A., 15 Business Horizon, Issue 5 (October 1972), p. 87.
} 
in the section to follow, difficulties lie not only in the characteristics and misuse of the sales method and the legislative responses given thereto, but also in the fact that the lobby group is deeply divided internally.

\subsubsection{Background to the Industry Lobby}

The aim of this sub-section is to supply the reader with background information on the lobbying organisations in the direct selling industry in order to better understand the dynamics of the interest group(s).

The first umbrella organisation representing the interests of the direct selling industry was founded in 1968 and was named the Federation of Direct Selling Associations, FEDSA. After almost fifty years of functioning as a European interest group with both corporate and national association members, FEDSA split in the years 2006 and 2007. The Austrian, Belgian, French, German, Italian, Luxembourger and Swiss national direct selling associations left FEDSA and founded Direct Selling Europe (DSE) - now the other main European direct selling trade association - in 2007. Since then, the direct member companies that left FEDSA by 2006 - Tupperware, Vorwerk, AMC, Lux and Pierre Lang - have joined DSE. ${ }^{37}$

Other associations, such as the French DSA, that had left FEDSA, did not join DSE. The French DSA returned to FEDSA in 2009, which was followed by the reorganisation of the entire trade association. FEDSA was renamed "Seldia, the European Direct Selling Association" and underwent major organisational restructuring in 2011. Since the realisation of the reforms, Seldia gained back some old associations and attracted new ones alongside new corporate members, but has lost AVON to DSE in 2015.

Seldia now has 28 national trade associations, covering practically the entire European Union (23 Member States) with the exception of the German speaking countries (Austria, Germany and Switzerland) and an Italian trade association, "Univendita" (the industry in Italy is split too - DSE's Italian member is "Univendita", while Seldia's is called "Avedisco").

Looking at corporate membership, it can be observed that Seldia's members are predominantly MLM in nature whereas DSE has a mixture of MLM (e.g. AMC or Jafra) and single-level marketing (e.g. Vorwerk) companies.

The various reasons for the industry split will be analysed in detail in sub-section 7.4.1. Here it suffices to say that Seldia claims it was the unfairness of the association's voting system that caused the rift, whereas DSE maintains it accepts and represents only

${ }^{37}$ DSE website, 'History of DSE', http://www.directsellingeurope.eu/basic-page/about-us/history (last visited 17 September 2014) 
those companies that have a strong record of ethical behaviour and have not been contested for the legality of their structure of operation.

\subsubsection{Background to Legislation and Self-Regulation}

In response to the idiosyncrasies and perhaps controversies of the direct selling channel, both legislators as well as the industry itself have adopted a number of protective and restrictive measures to safeguard consumers and direct sellers.

The current sub-section will first give a very brief overview of the three main protective measures that the European legislator has granted consumers in the framework of off-premises contracts, followed by a short indication of statutory measures safeguarding direct sellers. Thereafter, the industry's engagement with self-regulation will be introduced as an endeavour that aims to reduce the risk of government intervention, on the one hand, and which acts as a set of private norms that is complementary to European law, on the other hand.

Firstly, in so far as consumer contracts are concerned, the European legislature has granted consumers the right to receive pre-contractual information and to withdraw from off-premises (and distance selling) contract without giving any reason within a certain timeframe. The aim is to raise consumer confidence in certain distribution channels, such as direct selling and distance selling, as well as to compensate the information asymmetry between consumer and trader.

According to the European legal status quo, the right to withdraw is mandatory in off-premises and distance sales contracts, meaning that the consumer may not waive this right. The mandatory withdrawal right is thus considered by some authors like Eidenmuller and Reich as the erosion of the pacta sunt servanda principle ${ }^{38}$ by being overly protective towards the potentially irresponsible consumer. Still others, like the previously quoted Ben-Shahar, Posner and Smits ${ }^{39}$, believe that consumers' withdrawal right is a mere compensation for their weaker position and their lack of psychological strength in direct selling transactions.

\footnotetext{
${ }^{38}$ Eidenmuller, H., 'Why Withdrawal Rights?', 7 European Review of Contract Law, Issue 1 (January 2011) p. 1-24., and Reich, N., 'The Social, Political and Cultural Dimension of EU Private Law' in Schulze, R. and Schulte-Nolke, H. (Eds.), European Private Law - Current Status and Perspectives (Sellier European Law Publishers GmbH Munich, 2011), p. 57-89., p. 60.

${ }^{39}$ Ben-Shahar, O. and Posner, E. A., 'The Right to Withdraw in Contract Law', 40 Journal of Legal Studies, Issue 1, Article 4 (January 2011), p. 115-148., p. 120. and Smits, J. M., 'Rethinking the Usefulness of Mandatory Rights of Withdrawal in Consumer Contract Law: The Right to Change Your Mind', 29 Penn St. Int'l L. Rev. 671 (2010-2011), p. 672-683., p. 678.
} 
A key element of the European consumer acquis, the length of the withdrawal period has been fully harmonised by Directive 2011/83/EU on consumer rights" ${ }^{40}$ "Consumer Rights Directive") allowing consumers a uniform 14-day period to withdraw from the contracts concluded away from the traders' business premises.

Secondly, justified by purposes of consumer protection, the European legislature has given Member States the freedom to maintain or introduce total or partial prohibitions on the conclusion of contracts away from business premises by the predecessor of Directive 2011/83/EU, Directive 85/577/EEC ${ }^{41}$ (commonly referred to as "The Doorstep Selling Directive"). This has resulted in trading bans (ban of doorstep selling in Denmark ${ }^{42}$ ), product bans, i.e. the ban of distributing non-hazardous products through the direct selling channel (e.g.: ban of sale of food supplements in Hungary ${ }^{43}$ or certain items such as jewellery in Austria ${ }^{44}$ ), payment bans (e.g. the ban of payments before the expiry of the withdrawal period in France ${ }^{45}$ and Belgium ${ }^{46}$ ) and administrative restrictions (the obligation to announce sales- and promotional events to executive authorities in advance in Austria ${ }^{47}$, Hungary ${ }^{48}$ and Slovakia ${ }^{49}$ ).

The restrictive and/or prohibitive national measures have been contested in front of the Court of Justice of the European Union in a number of cases like Buet ${ }^{50}$, A-Punkt Schmuckhandels ${ }^{51}$, Burmanjer ${ }^{52}$ and TK-Heimdienst ${ }^{53}$ on the grounds that they distort

\footnotetext{
${ }^{40}$ Directive 2011/83/EU of the European Parliament and of the Council of 25 October 2011 on consumer rights, amending Council Directive 93/13/EEC and Directive 1999/44/EC of the European Parliament and of the Council and repealing Council Directive 85/577/EEC and Directive 97/7/EC of the European Parliament and of the Council Text with EEA relevance, [2011] OJ L 304

${ }^{41}$ Council Directive 85/577/EEC of 20 December 1985 to protect the consumer in respect of contracts negotiated away from business premises [1985]

OJ L 372

${ }^{42}$ Danish Act on Certain Consumer Contracts - Act No. 451 of 9 June 2004, Section 2

${ }^{43}$ Hungarian Government decree No. 370/2004. (XII. 26.) on contracts negotiated away from business premises and on certain conditions of trading away from business premises $\$ 6(2)$

${ }^{44}$ Austrian Gewerbeordnung 1994 - GewO 1994; StF: BGBl. Nr. 194/1994 (WV); §57 Abs. 1.: Aufsuchen von Privatpersonen

${ }^{45}$ Article L. 121-18-2 of the French Consumer Code and provided for in Article 9 of Law No. 2014-344.

${ }^{46}$ Article VI.67, \$2 last paragraph, Belgian Code on Economic Law

${ }^{47}$ Austrian Gewerbeordnung (GewO) $\$ 57$ Abs. 1: Aufsuchen von Privatpersonen

${ }^{48}$ Hungarian government decree No. NGM/10342/4/2013 to amend the government decree 210/2009. (IX. 29.) on the conditions of conducting commercial activities

${ }^{49}$ Act of 29 October 2013, amending and supplementing Act no. 108/2000 Z. z. on Consumer Protection in Doorstep Selling and Mail Order Selling, as amended by later regulations, and supplementing Act no. 128/2002 Z. z. on State Supervision of Internal Market in Matters of Consumer Protection and amending and supplementing some acts, as amended by later regulations

${ }^{50}$ Case C-382/87 R. Buet and Educational Business Services (EBS) v Ministère public [1989] ECR1235

${ }^{51}$ Case C-441/04 A-Punkt Schmuckhandels GmbH v Claudia Schmidt [2006] ECR I-2093

${ }^{52}$ Case C-20/03 Criminal proceedings against Marcel Burmanjer and Others [2005] ECR I-4133
} 
the internal market principle and hamper the liberalisation of trade. The Court has delivered rather ambiguous rulings in some of these cases, upholding a degree of legal uncertainty in respect of the permissibility of direct selling trade barriers. The battle between protectionist Member States and the industry promoting trade liberalisation is, however, expected to gain new momentum with the entry into force of the Consumer Rights Directive that no longer entitles Member States to introduce or maintain restrictions to, or prohibitions of the conclusion of, off-premises contracts with the exception of already existing payment bans, insinuating a firm transition towards the abrogation of the restrictive measures in question. ${ }^{54}$

Thirdly, within the normative framework of fair trading regulation, in order to protect consumers from pyramid schemes, the European legislator has introduced a ban of these types of fraudulent schemes. It will be argued later on in the thesis, in the chapter on pyramid schemes (chapter IV), that - while the restrictions and the bans on the direct selling channel are at times too protective of the consumer at the cost of the devolution of the internal market - the current European pyramid scheme regulation is inadequate as it offers protection to consumers against pyramids but fails to protect the other victims of pyramid schemes, the direct sellers who operate micro- and small businesses in the framework of slightly more sophisticated pyramids that are disguised as legitimate MLMs. ${ }^{55}$

As for the mandatory safeguards defending direct sellers (as traders), the first Directive to be mentioned is that concerning commercial agents. ${ }^{56}$ The objective of the Commercial Agents Directive, an instrument of minimum harmonisation, is to take steps towards the establishment of the single market for commercial representation as well as to improve the conditions of competition by facilitating the conclusion and operation of commercial representation contracts across borders through harmonised rules. For this purpose, the Directive defines the commercial agents falling under its scope and harmonises the rights and obligations of commercial agents and their principals, and defines rules for the remuneration of the commercial agent, the conclusion

\footnotetext{
${ }^{53}$ Case C-254/98 Schutzverband gegen unlauteren Wettbewerb v TK-Heimdienst Sass GmbH. [2000] ECR I-151

${ }^{54}$ Save where otherwise expressly provided by the Directive, Article 4 stipulates that Member States shall not maintain or introduce, in their national law, provisions diverging from those laid down in the Directive, including more or less stringent provisions to ensure a different level of consumer protection.

${ }^{55}$ In addition, European law offers protection to both consumers and direct sellers (who are considered businesses by definition) against misleading or false claims made either concerning the products or the recruitment procedure through Directive 2005/29/EC concerning unfair business to consumer commercial practices and Directive 2006/114/EC concerning misleading and comparative advertising (in B2B transactions) although not just or not specifically to off-premises contracts.

${ }^{56}$ Council Directive 86/653/EEC of 18 December 1986 on the coordination of the laws of the Member States relating to self-employed commercial agents [1986] OJ L 382
} 
and the termination of the contract and the restraint of trade after the termination of the contract. ${ }^{57}$

In the field of marketing law, an important protection is granted by Directive 2006/114/EC concerning misleading and comparative advertising ${ }^{58}$ to direct sellers against misleading advertising, which, in the field of direct selling, tends to materialise in the form of false earnings claims made in the course of the recruitment process.

Moreover, the Consumer Rights Directive allows Member States, as a measure of minimum harmonisation, to extend the scope of the Directive to legal persons or to natural persons who are not consumers within the meaning of the Directive, such as non-governmental organisations, start-ups or small and medium-sized enterprises ${ }^{59}$ which means that direct sellers running SMEs may be subject to the same protection as consumers, including the right of withdrawal, depending on the implementation of the Directive in the Member State of their operation.

However, European unfair competition law does not offer protection to direct sellers (such as businesses) against pyramid promotional schemes - it is only the consumers at the moment who are covered by the current pyramid scheme definition as enshrined in Item 14 Annex I of Directive 2005/29/EC concerning unfair business to consumer commercial practices ${ }^{60}$ ("Unfair Commercial Practices Directive", UCPD).

Subsequent to the indication of the most important safeguards granted by statutory law, protective measures of the industry's Codes of Conduct are also to be taken note of. The industry has established a sector-specific normative framework that harmonises standards of fair trading towards consumers, direct sellers and direct selling corporations and sets the requirements of professional diligence for the direct selling industry. The direct selling industry's Codes, as will be described in detail in chapter V on selfregulation, act as agents of European harmonisation and thereby substantiate and complement EU law. Adherence to the private regulatory framework is ensured by private enforcement measures as well as European law that sanctions non-compliance with a signed code of conduct.

\footnotetext{
57 European Commission, Evaluation of the Commercial Agents Directive (86/653/EEC), 'Objectives', http://ec.europa.eu/internal_market/consultations/2014/commercial-agents-directive/index_en.htm (last visited 17 September 2014)

${ }^{58}$ Directive 2006/114/EC of the European Parliament and of the Council of 12 December 2006 concerning misleading and comparative advertising (codified version) (Text with EEA relevance) [2006] OJ L 376

${ }^{59}$ Recital 13, Directive 2011/83/EU

${ }^{60}$ Directive 2005/29/EC of the European Parliament and of the Council of 11 May 2005 concerning unfair business-to-consumer commercial practices in the internal market and amending Council Directive 84/450/EEC, Directives 97/7/EC, 98/27/EC and 2002/65/EC of the European Parliament and of the Council and Regulation (EC) No 2006/2004 of the European Parliament and of the Council ("Unfair Commercial Practices Directive") (Text with EEA relevance) [2005] OJ L 149
} 
All in all, there are a certain number of "problem areas" concerning the direct selling channel which legislators have attempted to rectify by putting protective measures into place. The interplay between the industry adversaries and the policy responses given thereto define the battlefield for industry lobbyists who have been entrusted with the task to reduce restrictive measures and, for that purpose, fight against the stigmatisation and public condemnation of the sector. This battlefield, the most sensitive territory of direct selling, is the area covered by the industry self-regulation that at times contains stricter or more detailed norms than statutory measures.

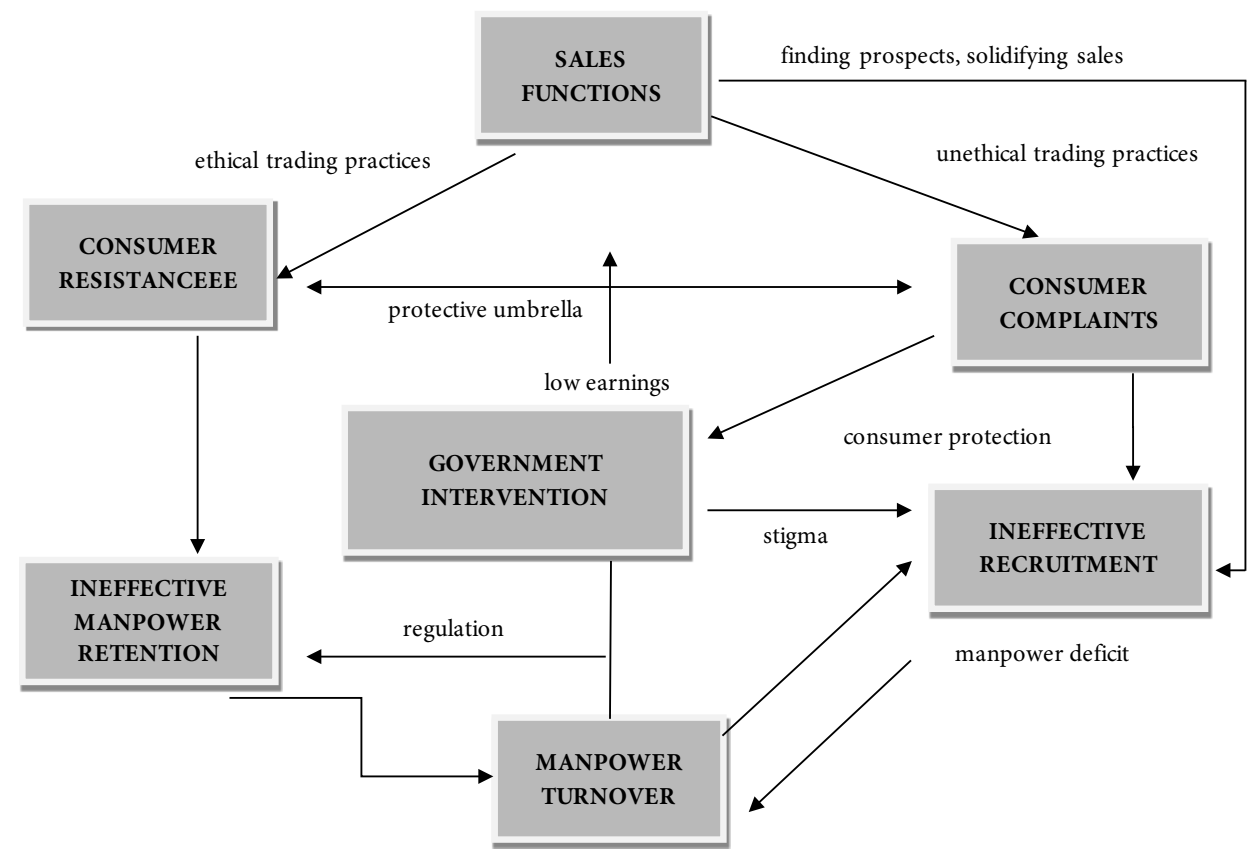

Interrelationship of Problem Areas Facing Direct Selling

The table was reproduced from Johnson, M. A., Consumer Attitudes Toward Direct-toHome Marketing Systems (Dunellen Publishing Company, New York, 1970), p. 5. in Jolson, M. A., 'Direct Selling: Consumer vs. Salesman - Is Conflict Inevitable?', 15 Business Horizon, Issue 5 (October 1972) p. 94. 


\subsection{Academic and Practical Relevance of the Study}

The academic relevance of the study is its contribution to the enhancement of lobbying transparency and the fact that it is the first comprehensive legal and empirical enquiry into the direct selling industry's interest representation in the EU.

The European Union can be considered to be a pluralistic political system with free competition among advocacy groups whereby lobbying plays a role of key importance. In this respect, the Brussels political arena favours small producer groups that prefer pluralism over corporatism, which automatically involves consumer groups and relatively weakly organised producer groups. These interest groups hire lobbyists to build a strong base in Brussels and to attempt to influence European policymakers to their advantage and, despite steps to elucidate the impact of lobbying on EU law (such as the establishment of the non-mandatory Transparency Register), concerns relating to the openness of decision-making continue to exist. ${ }^{61}$ The lack of transparency of the decision-making process can easily lead to the distortion of representation of various interest groups in the system of free competition, whereas the increased openness of the procedure ensures balanced representation, the avoidance of undue pressure, illegitimate or privileged access to information or to decision-makers and, lastly, encourages citizens' active political participation. In summary, transparency of the decision-making process is a vital aspect of democracy and the present study purposes to contribute to the elucidation of lobbying activities in the EU.

The study offers insights into a specific industry's strategic interests, political strategies and various modes of organisational interest representation that have shaped European law and the extent to which the industry lobby has managed to influence the resulting norms. Hence, the contribution helps the reader to arrive at a clearer understanding of both the substantial outcomes of direct selling industry lobbying as materialised in legal provisions, by shedding light on the direct selling industry interests that have impacted legislation in the path leading up to the adoption of various pieces of legislation, as well as through the elucidation of less transparent aspects of interest representation techniques and deliberations with the EU legislators as part of the political strategies of this particular industry.

The study's innovative nature is thus twofold: firstly, from the aspect of legal research, the novel element is the detailed analysis of the specific interests, positions and legislative proposals that have been put forward by the direct selling industry in the

\footnotetext{
${ }^{61}$ Svendsen, G. T., 'Evaluating and Regulating the Impacts of Lobbying in the EU? The Case Study of Green Industries’, 21 Environmental Policy and Governance, Issue 2 (2011), p. 131-142, p. 132-133.
} 
course of its advocacy activities, that is to say, the assessment of the extent to which these interests have been materialised in the legislative output, shaping the norms of European private law.

The second innovation concerns the systematic exploration of the direct selling industry's lobbying methods in the Brussels political arena from a political science perspective. It is the first overarching (albeit not representative) empirical research that has been carried out to examine and analyse the -at times hidden- means through which the industry's various forms and organisations of interest representation attempt to influence policymakers.

The practical relevance of the study's findings lie in the elucidation of lobbying activities: the evaluation of the industry lobby's results and influence on substantive norms in the context of competing interests, whereas the systematic and objective (although not exhaustive) overview of various actors' lobbying behaviour and advocacy tendencies both separately as well as in their entirety attempts to explore and analyse the industry's advocacy strategies from a political science perspective. From this, the direct selling industry, business interest groups, European decision-makers and politically active citizens in general may take away important findings.

\subsection{Objectives of the Study and Research Questions}

Direct selling - compared to other distribution channels- is a small industry struggling with its own reputational shortcomings and public condemnation resulting from the controversies and abuse of the retail method, as was described previously.

While characteristics and controversies of the distribution channel are frequently subject to analysis from an economic perspective, comprehensive research is rather scarce on the way the industry's idiosyncrasies and adversities shape legislation and the sector's political strategies and techniques of interest representation. ${ }^{62}$ The aim of the

\footnotetext{
${ }^{62}$ Perhaps the best overview of the development of the direct selling industry's legal aspects (although mostly from a US perspective) is Mariano, J. and Brossi, M., Multilevel Marketing: A Legal Primer (2nd Edition, Publisher: Direct Selling Association (US), Washington, 1997) whereas Jan M. Smits's publications, 'Full Harmonisation of Consumer Law? A Critique of the Draft Directive on Consumer Rights', 18 European Review of Private Law (2010), p. 5-14. and 'Rethinking the Usefulness of Mandatory Rights of Withdrawal in Consumer Contract Law: The Right to Change Your Mind?', 29 Penn State International Law Review (2011), p. 671-684. as well as Stephen Weatherhill's contributions are of key importance concerning the development of consumer law in off-premises contracts, e.g.: 'The Consumer Rights Directive: How and why a quest for coherence has (largely) failed', in 49 Common Market Law Review, (2012), p. 1279-1318., or 'After Keck: Some Thoughts on How to Clarify the Clarification' in 33 Common Market Law Review (1996) p. 885-906., Steennot's study on direct selling trade barriers (Steennot, R., 'Are rules prohibiting the doorstep selling of certain
} 
current study is therefore to explore and provide an in-depth understanding of the direct selling industry's lobby in the European Union and the interplay thereof with EU law. The thesis is meant to be an academic contribution to facilitate the thorough comprehension of the way and the extent to which a certain industry lobby has influenced the aspects of European law in the fields relevant for the industry, and, secondly, to elaborate on the advocacy methods that are utilised by the industry in an effort to exert influence upon the European legislator. To that end, on the one hand, the strategic goals and interests of the sector will be construed in detail, and will thereafter be compared to the final legislative output (be it statutory law or private regulations) in each case study or, in the case of the "Entrepreneurship dossier", the industry lobby will be described in light of the policies it attempts to influence. On the other hand, empirical research results will be presented and discussed in the framework of the political sciences theories discipline, and, in particular, the public choice-, the group size- and the access theory.

Consequently, the first main objective is to identify the strategic goals of the direct selling industry in terms of shaping European law and public policy. This objective is met through answering the following research questions:

1. Which legal instruments exist in the EU currently that regulate key aspects of the direct selling industry and serve as basis of the present legal enquiry into the industry lobby?

2. What are the strategic legislative lobbying goals of the direct selling industry's interest representation in Brussels?

3. To what extent did the industry advocacy manage to influence European law and shape it according to its needs?

4. What are the non-legislative strategic lobbying goals of the direct selling industry's interest representation in Brussels?

Structurally, the way the above research questions will be answered is the following: the "preliminary" research question concerning the legal instruments serving as the basis of the legal enquiry will be answered in the second chapter entitled "Legal Overview". This chapter is purely descriptive in its nature, as it is the groundwork essential

goods and prohibiting the itinerant selling of goods and services without prior authorization compatible with the EU-Treaty and the Unfair Commercial Practices Directive?' - Universiteit Gent, Financial Law Institute, Working paper Series, WP 2013-04, August 2013, http://www.law.ugent.be/fli/wps/pdf/WP2013-04.pdf (last visited 17 September 2014) and Paul Dobson's paper on the pyramid scheme regulation in the EU and its scope of application (Dobson, P., 'Does the ban on pyramid promotional schemes challenge the business model of a typical direct selling company?' in 2 Journal of Business Law (2011) p. 194-207 are highly important works in this field of research. 
for the understanding of the subsequent lobbying dossiers and as such, it does not aim to provide in-depth legal analyses.

The three subsequent chapters introduce, as individual case studies, three "dossiers" of legislative lobbying and assess, one by one, what the direct selling industry's key interests have been concerning the shaping of consumer law (chapter III), the pyramid scheme regulation (chapter IV) and self-regulation (chapter V), and whether the industry advocacy's goals have had substantial outcomes in the respective dossiers. Finally, a non-legislative lobbying dossier, the promotion of entrepreneurial values (chapter VI) will be examined with a special focus on the objectives and methods of this advocacy field. While being aware of the fact that the fourth dossier would perhaps fit better into the framework of the thesis's technical inquiry, it is featured as a separate lobbying dossier given the thematic role the issue plays in the industry advocacy, on the one hand, and the legislative lobbying potential the dossier holds on the other hand.

In the course of the assessment of the lobbying dossiers, besides the introduction of the direct selling industry's strategic interests and positions - the theme that is the focal point of the thesis - positions of competing political groups, Member States or interest groups will also be reflected upon in an effort to place these case studies into a sociopolitical context and to elucidate on the various other interests in the pluralistic system of European law making.

Accordingly, Dossier I on the Consumer Rights Directive describes the positions of the European institutions, various Member States, the direct selling industry and the consumer movements (spearheaded by BEUC) connected to the adoption of this piece of legislation (see section 3.4.). Dossier II on the pyramid scheme regulation elaborates on the industry's position in contrast to that of an independent study, the VIEW Final Report (published in November 1999) compiled upon request of the European Commission on the legislative revision of the entire field of direct selling based on the comparative analysis of Member States' regulatory frameworks. Moreover, in order to gain an even more comprehensive and objective understanding of the dossier and alternative regulatory models, the enquiry into the pyramid scheme definition also outlines the US model, detailing the key features and the main safeguards of the American pyramid scheme regulation developed by the American legislators and judiciary. Finally, the dossier is evaluated in sub-section 4.3.2 in light of both the industry's interests as well as the position of critiques from within and outside the industry.

Discussing self-regulation, Dossier III in part seeks to answer the question as to whose interest the direct selling industry's engagement in private regulation really works for. This chapter looks into the motives of the industry, but also examines whether the Codes of Ethics also promote the interests of consumers and direct selling agents too 
and, thus, if self-regulation also serves societal interests or whether it is only a cynical attempt to further industry interests.

Dossier IV deals with entrepreneurship promotion as a non-legislative lobbying dossier. While this is mainly a PR dossier campaigning clearly pro-direct selling, and as such, leaves less room for interpretation or doubt concerning the aims it serves, it is still analysed from a thematic perspective - how and why this issue is capable of creating partnership with European politicians and whether the topics that have been chosen are substantial and capable of furthering societal interests. More specifically, it will be highlighted how the promotion of entrepreneurship in general and women entrepreneurship may be beneficial from an economic- and gender quality perspective, but that the avoidance of equally relevant, albeit more controversial issues, such as immigrant entrepreneurship or the consolidation of tax rules may be a missed opportunity to discuss significant political and socioeconomic issues.

Following this breakdown of various dossiers, the issue of competing interests and lobbying as a rational choice are revisited in chapter VII from a political sciences perspective.

The second main objective is to identify, compare and analyse the organisational forms of direct selling interest representation and the lobbying techniques applied by each actor, bearing in mind that an exhaustive research was not possible due to the sensitive nature of the enquiry. This objective is met through finding adequate responses to research questions 5) - 11):

5. What are the main organisational forms of direct selling interest representation?

6. Does direct selling advocacy comply with the theses of the public choice theory?

7. What is the reason why a small and sectorial interest group such as direct selling industry advocacy could have had a relatively considerable impact on certain aspects of European private law overall?

8. Is the performance of the industry lobby even and equally strong throughout the legislative procedure?

9. In what ways does the fourth, non-legislative dossier influence political decision-making?

10. What type of advocacy strategies does each lobbying actor adopt?

11. How do the various actors' lobbying techniques interrelate and to what extent are they complementary? 
Answers to these research questions will be provided in chapter VII on the strategies and techniques of direct selling industry interest representation in the Brussels political arena.

\subsection{Research Methodology}

As the present study lies at the intersection of European law and political sciences, research methods of both knowledge domains have been utilised - the first part of the thesis applies methods of legal research, whereas the second employs empirical techniques.

The aim of the legal investigation into the direct selling industry's advocacy in the EU was to understand relevant fields of legislative lobbying and the extent to which the industry is capable of shaping European law.

For that purpose, legal research of the lobbying dossiers has been conducted through a problem-based approach. Following the identification of legal problems and relevant legal matters for the direct selling industry, the allocated issues have been analysed in detail primarily from the perspective of this particular interest group (and its various actors), focusing on the legislative outcome the industry lobby strived to achieve.

To this end, thorough content analysis of relevant legislative proposals, policy documents, legislation and CJEU judgments has been undertaken as the starting point of the industry advocacy's activities. Thereafter, in order to look into the strategic interests according to which the industry intended to influence European legislation, publicly available documentation indicating lobbying actors' detailed positions and the underlying reasoning have been analysed in detail.

The scrutiny concerning relevant legislation and the specific positions of lobbying actors on the allocated legal issues is followed by the evaluation of the substantive output of the legislative procedure and deliberations between the European legislature and the various interest groups. The aim of the comparison is to research the actual efficacy of the direct selling industry advocacy, or, in simpler terms, to study whether the industry lobby is successful in shaping European law according to its needs and interests.

It must be noted that the fourth lobbying dossier, the promotion of entrepreneurial values (chapter VI) is not a legislative lobbying dossier. Therefore it has not been the subject of legal research in the sense under which the first three lobbying dossiers were assessed, yet, this chapter also contains issues concerning substantive law, i.e. the inclusion of legislative issues into the portfolio. 
Throughout the legal enquiry in particular, frequent references are made to the United States regulatory model of the direct selling industry. The modern direct selling industry can be considered to have pioneered in the US with the establishment of AVON in 1886, and, in the 1950s, with the emergence of MLM companies such as Tupperware or Amway. However, the success of the multi-level marketing model has also led to the appearance of fraudulent money circulation schemes, defrauding consumers and direct sellers alike. ${ }^{63}$ Faced with new challenges, it was the American legislature and judiciary that first had to respond to the emergence of the new business model and offer protection against abuses and controversies connected to the sales channel. The US being the oldest and strongest market for direct selling, it is also (one of) the leading examples of direct selling regulation. Especially when considering the shaping of laws governing the field of direct selling, it is worth looking at already functioning regulatory models and legal solutions, wherefore the present study looks over the overseas model on a regular basis.

Inquiry into the political strategies and techniques of interest representation of the direct selling industry has been conducted through a comprehensive empirical research where the goal was to provide a systematic understanding of not only each type of organisational interest representation (European trade associations, national trade associations, individually lobbying corporations, corporations lobbying through collective action and third party interest representation [through consultancies]) but also the way the advocacy actions of various actors complement and/or conflict with each other.

The empirical research is carried out through semi-standardised in-depth interviews and standardised questionnaires. Participation in the research was voluntary; strict confidentiality has been maintained to the people and organisations involved. Semistructured qualitative interviews have been conducted with a number of experts and representatives of the direct selling industry advocacy - directors and key officials of the two European trade associations, Seldia and DSE, executives and public affairs officials of four direct selling corporations and a third party representative. National direct selling associations in the EU have been sent a standardised questionnaire concerning their activities of interest representation in Brussels to which 11 direct selling associations have responded, providing the basis in the form of an accidental sample for the analysis.

Results of both the legal- and empirical research are studied in the framework of political sciences theories. The main motivations of the industry lobby, the political deliberations and lobbying against competing interests and the final outcome of the industry

${ }^{63}$ KPMG India: Direct Selling - A global industry empowering millions in India, 2012, available at https:/www.kpmg.com/IN/en/IssuesAndInsights/ArticlesPublications/Documents/Direct-Selling.pdf (last visited on 7 July 2015) 
advocacy are analysed through the paradigm of the public choice theory. In particular, the research focused on what interests are the driving forces behind the advocacy actions of various players throughout the legislative procedures, the engagement in selfregulation or the promotion of entrepreneurship based on the foundations laid down by Downs, Tullock or Lukes and placed in context by Gary Becker's pluralistic system of competing interest groups.

Interest representation structures and techniques of the direct selling industry are subsequently analysed on the basis of Mancur Olson's theory of collective action as well as Pieter Bouwen's access theory, a model of interdependence between private interests and EU institutions where business interests and public actors rely on each other in the access of resources. ${ }^{64}$ In other words, an existing theoretical model has been applied to the new empirical domain of direct selling in order to provide a solid foundation of understanding and to analyse this particular distribution method's modes of interest representation.

In summary, the legal analysis is aimed at providing a deeper understanding of the substantive issues of influencing European law, whereas the empirical research and the analysis thereof through political doctrines is intended to shed light on the methods and techniques of private interest representation within the pluralistic system of the Brussels political arena.

\subsection{Structure of the Study}

The structure of the thesis is as follows. Overall, the first part - the legal enquiry - identifies the strategic goals and dossiers of the industry advocacy, whereas the second part describes the lobbying techniques of the industry's various actors both separately as well as in their entirety.

Foundations for the understanding of the strategic goals are provided by a brief legal overview in chapter II, giving a synopsis of the existing regulation of the direct selling industry that is relevant from the perspective of the lobbying dossiers to be discussed in subsequent chapters. This chapter is not meant to provide an in-depth analysis of the legal issues at hand; it is rather an introductory chapter that is descriptive in its nature to allow an understanding of the case studies provided later in the thesis.

The Consumer Rights Directive as a piece of the current European consumer acquis regulating direct selling transactions as well as the lobbying actions that accompanied

${ }^{64}$ Bouwen P., 'Corporate lobbying in the European Union: towards a theory of access', 9 Journal of European Public Policy, Issue 3 (2002), p. 365-390. 
the Directive's adoption are analysed in chapter III from the perspective of industry interests, evaluating the outcome based on the initial position and the proposals made by the sector against the political conflicts and decade-long deliberation the intended comprehensive legislative revision has brought to the surface. The special problem of consumer protection through direct selling trade barriers - which are no longer permitted by the Directive- and the underlying conflict of protectionist measures and trade liberalisation is discussed as part of this chapter.

The European pyramid scheme definition, the Achilles heel of European fair trading law from the perspective of multi-level marketing, will be dealt with in chapter IV. The evolution and adoption of the relevant provision, as enshrined in Directive 2005/29/EC concerning unfair business-to-consumer commercial practices in the internal market ${ }^{65}$ will be analysed in light of the industry interests versus academic recommendations in detail.

Chapter V describes the industry's self-regulatory efforts as a means to establish a comprehensive framework of private norms setting high standards for the industry in an effort to fend off stringent legislative responses given to the abuses of the sales channel, as well as to improve the overall reputation of the industry. It will be discussed how the industry's Codes of Conduct set uniform standards that not only reinforce, but at times even complement EU law, providing a compass for the European legislature although, as will be indicated, the Codes themselves may be in need of clarification.

A purely non-legislative lobbying goal, the aspiration to improve reputational shortcomings through the promotion of the now popular entrepreneurial values, as an integral part of the direct selling industry, is dealt with in chapter VI, alongside with suggestions on how to further develop the dossier by the inclusion of legislative goals.

The second main part of the thesis, chapter VII, discusses the results of the legal- and the empirical research conducted on the direct selling industry's interest representation techniques.

First of all, findings of both studies are discussed and interpreted in the framework of the public choice theory and Mancur Olson's theory of collective action.

Secondly, assessment of the strategies through which direct selling advocacy attempts to gain influence over public policy is provided. A systematic assessment of approach towards European institutions has been carried out in an effort to identify the

\footnotetext{
${ }^{65}$ Directive 2005/29/EC of the European Parliament and of the Council of 11 May 2005 concerning unfair business-to-consumer commercial practices in the internal market and amending Council Directive 84/450/EEC, Directives 97/7/EC, 98/27/EC and 2002/65/EC of the European Parliament and of the Council and Regulation (EC) No 2006/2004 of the European Parliament and of the Council ("Unfair Commercial Practices Directive") (Text with EEA relevance) [2005] OJ L 149
} 
strategies various interests deploy to obtain influence over the EU's multi-level policy making process. For that purpose, patterns of each direct selling advocacy actor's lobbying behaviour have been established and compared to empirical findings of Pieter Bouwen's comprehensive model of European interest representation and institutional access theory.

Finally, chapter VIII sums up the findings of the thesis, highlighting the answers to the initial research questions and summarising the key elements of the direct selling industry lobby in the Brussels political arena. 
A Legal Overview 



\subsection{Introduction}

The current chapter provides an overview of the European legislation governing the most important aspects of the direct selling channel relevant for the purposes of the present study. The aim of what may sometimes appear as a lengthy description of legislative acts is to offer a better understanding of the specificities of the direct selling sector's regulation in Europe and thus, the whys and wherefores of the industry's lobbying strategies and lobbying actions addressed to the EU policymakers. This is a necessary step before the interests and lobbying strategies of the industry can be analysed (as is done in chapters III, IV, V and VI) but at the same time the purpose is solely to ease the understanding of the lobbying dossiers through the provision of a brief descriptive overview and not to provide an in-depth analysis of the legal instruments.

The first part of the chapter (section 2.2.) describes European consumer contract law governing off-premises contracts specifically and is the preparatory groundwork for the first case study on the industry's position and advocacy actions in relation to the Consumer Rights Directive. Within this framework, in sub-section 2.2.1., Directive $85 / 577 /$ EEC to protect the consumer in respect of contracts negotiated away from business premises ${ }^{66}$ (generally referred to as the "Doorstep Selling Directive") is introduced, as the first European lex specialis governing the sector. This piece of legislation is interesting both in terms of the history of European consumer law as well as from the perspective of the history and evolution of direct selling regulation in the EU.

Special attention is paid to distinctive features of direct selling transactions, namely the situational and temporary monopoly the trader creates in an off-premises retailing context which may lead to an irrational consumer choice as regards the purchase. Compensating for the aforementioned specificities of direct selling, the European legislator provided consumers with an enhanced level of protection through this Directive, obliging traders to meet certain informational requirements and allowing consumers to rescind from the transaction altogether within a certain timeframe - the cooling-off period - following the conclusion of the contract.

As the Doorstep Selling Directive was repealed by Directive 2011/83/EU on consumer rights ("Consumer Rights Directive", CRD), provisions of this novel legal act regulating off-premises contracts are also introduced in sub-section 2.2.2. Although the Consumer Rights Directive covers both distance selling and direct selling, attention is paid to the latter aspect only. Important changes that the Consumer Rights Directive has

\footnotetext{
${ }^{66}$ Council Directive 85/577/EEC of 20 December 1985 to protect the consumer in respect of contracts negotiated away from business premises [1985] OJ L 372
} 
brought about will be highlighted later on, concentrating on alterations relating to the level of harmonisation, the scope of application, information requirements and the standardisation of the withdrawal period as well as the introduction of a de minimis threshold.

The second part of the chapter (section 2.3.) deals with fair trading in business-toconsumer relations as governed by Directive 2005/29/EC concerning unfair business-toconsumer commercial practices in the internal market ("Unfair Commercial Practices Directive", UCPD) (2.3.1.) and with fair trading in business-to-business relations as governed by Directive 2006/114/EC concerning misleading and comparative advertising ("Misleading and Comparative Advertising Directive", MCAD) (2.3.2.). The brief description of the European unfair competition law is relevant for understanding the lobbying dossier on the pyramid scheme definition and the industry's self-regulatory efforts.

The Unfair Commercial Practices Directive covers a considerably wider scope of commercial contracts than the Doorstep Selling Directive and the Consumer Rights Directive, and is of paramount importance for the direct selling industry. The section on the UCPD will therefore only highlight the provisions relevant for the sector with a special focus on misleading income claims (as a form of misleading commercial practices), aggressive practices, the Directive's provisions on self-regulation and, lastly, the pyramid scheme definition - a feature pivotal for multi-level marketing companies.

Finally, the main provisions of the Misleading and Comparative Advertising Directive are described in order to provide a comprehensive overview of marketing law, looking into the business-to-business aspect of advertising.

There are two directives that - despite their importance from the perspective of European law and the direct selling industry - will not be featured in this study: Directive 93/13/EEC on unfair terms in consumer contracts ${ }^{67}$ ("Unfair Contract Terms Directive") and Directive $86 / 653 /$ EEC on the coordination of the laws of the Member States relating to self-employed commercial agents ${ }^{68}$ ("Commercial Agents Directive").

A salient piece of legislation, the Unfair Contract Terms Directive regulates the content of contracts and defines rights and duties of the contracting parties, but is not a key priority for the direct selling industry lobby as the Directive's provisions do not constitute any concern or "threat" from an advocacy perspective for the industry.

The Commercial Agents Directive, on the other hand, is more problematic from the industry's perspective. As a consequence of minimum harmonisation offered by the

\footnotetext{
${ }^{67}$ Council Directive 93/13/EEC of 5 April 1993 on unfair terms in consumer contracts [1993] OJ L 95

${ }^{68}$ Council Directive 86/653/EEC of 18 December 1986 on the coordination of the laws of the Member States relating to self-employed commercial agents [1986] OJ L 382
} 
Directive, the status of direct sellers differs from Member State to Member State causing not only higher costs of compliance for multinational corporations and barriers to cross-border trade but also, in some jurisdictions, particular administrative difficulties (such as legal obligations of registry at various authorities) or taxation issues (relating to the payment of income tax, VAT, additional taxes relating to the establishment of businesses as well as the payment of social contributions). In other words, while the establishment and operation of SMEs is relatively problem-free in some Member States, other Member States maintain laws that discourage entrepreneurship, which then means that the expansion of direct selling corporations that rely on their direct sellers' businesses is restrained. Conclusively, the idea to lobby for the full harmonisation of direct sellers' status within the EU has arisen and was also pointed out to EU institutions by certain industry actors, although not as a concise dossier representing the entire industry's position.

Taking note of the articulated problem, the European Economic and Social Committee has drawn up a draft own-initiative opinion on "Direct sellers: the specific case of economically independent self-employed workers" ${ }^{69}$ in 2012 , recommending that the Commission harmonises the definition of self-employment in the sector in order to encourage entrepreneurship, the creation of jobs and growth, as well as to increase legal certainty for SMEs in Europe. The initiative was rejected, however, given that the representatives of the Employees within the EESC opposed the initiative due to the insecurity of the direct selling activity. Furthermore, it must also be remarked that neither of the European trade associations showed any sign of open support of the initiative. Following the EESC initiative concerning the harmonisation of the status of direct sellers, no steps have been taken by the industry to influence the realm on its merits.

Therefore, due to the lack of a clear lobbying concept within the direct selling industry regarding the status of direct sellers in the EU, it was decided that the issue will not be dealt with in more detail by the present research.

\footnotetext{
${ }^{69}$ European Economic and Social Committee: INT/654 Direct sellers, Working Document of the Section for the Single Market, Production and Consumption on Direct sellers: the specific case of economically independent self-employed workers, 10 October 2012.
} 


\subsection{Consumer Law for Direct Selling}

\subsubsection{The Doorstep Selling Directive}

The current section will describe Directive 85/577/EEC - more commonly known as the "Doorstep Selling Directive" - regulating consumer protection aspects of contracts negotiated and concluded away from the trader's premises as one of the first pieces of European consumer legislation.

What will be described first is the need for this Directive and the protective measures it has offered in light of the specificities of the sales channel, followed by a discussion of controversies surrounding the choice of legal basis. The minimum harmonisation nature of the Directive and a very important consequence thereof, Member States' entitlement to maintain or introduce restrictions or bans on off-premises contracts for the purposes of consumer protection within the limits of the proportionality principle, will be analysed later on.

\subsubsection{The Need for Extra Protection}

Off-premises contracts were governed by the Doorstep Selling Directive to protect the consumer in respect of contracts negotiated away from business premises. The Directive was the first lex specialis granting consumers extra protection when entering into direct selling transactions with traders. The introduction of the Doorstep Selling Directive was part of the "sea of change" and the rise of consumer law, as Micklitz puts it, of the adoption of EU consumer policies in the 1970s and 1980s that occurred with the adoption of the so-called Sutherland Report ${ }^{70}$ that discovered the consumer as an actor of the internal market. ${ }^{71}$

The Doorstep Selling Directive was an important legislative measure that provided consumers with the necessary protection before, during and after the conclusion of offpremises contracts with traders. This Directive has drawn on the traditional justification of consumer protection and reflected on the doctrine of inequality of bargaining power based on the notion that consumers are in considerably weaker economic positions than

\footnotetext{
70 The Internal Market after 1992: Meeting the Challenge. Report presented to the Commission by the High Level Group on the Functioning of the Internal Market, as cited by Micklitz, H-W., 'Do Consumer and Businesses Need a New Architecture of Consumer Law? A Thought Provoking Impulse', EUI Working Papers, Law 2012/23, Department of Law, available at http://papers.ssrn.com/sol3/papers.cfm?abstract_id=2169226 (last visited 17 June 2015), p. 4.

${ }^{71}$ Micklitz, H-W., 'Do Consumer and Businesses Need a New Architecture of Consumer Law? A Thought Provoking Impulse', EUI Working Papers, Law 2012/23, Department of Law, available at http://papers.ssrn.com/sol3/papers.cfm?abstract_id=2169226 (last visited 17 June 2015), p. 4.
} 
traders: not only are consumers less knowledgeable and weaker, but they are also influenced by advertising, which poses further challenges for them in making valid and informed choices. The inequality of the contractual parties is what necessitates the state to counterweigh the consumers' weakness by providing them extra rights and safeguards inter alia consumers are allowed to withdraw from off-premises contracts within a certain timeframe following the conclusion of the contract to protect them.

\subsubsection{A Controversial Legal Basis}

Based on Article 100 of the Treaty establishing the European Economic Community (now Article 115 of the TFEU), the Doorstep Selling Directive aimed to approximate laws in the field of off-premises contracts as 'disparity between such legislation may directly affect the functioning of the common market. ${ }^{72}$ The fact that a measure of consumer protection has been based on the provision purposing to establish and enhance the internal market has long been subject to controversy. Consumer policy being a shared competence between Member States and the EU, the EU has limited powers to act in this field. Historically, when consumer law started to evolve at the Community level, there was no legal basis in the Treaties at all for adopting measures in this field. The only available legal basis was Article 100 of the Treaty Establishing the European Economic Community, the object of which is the establishment and functioning of the internal market. It is for this reason that the Doorstep Selling Directive - like all measures of consumer protection at the time - has been based on the provision of what is now Article 115 TFEU. ${ }^{73}$ Passing measures based on this article and this particular approach to consumer policy has nonetheless meant that it was not so much autonomous EU rules that were created as a result of European legislation, but that national laws have been approximated in certain fields of consumer law. ${ }^{74}$

It is believed by some scholars of European law, including Stephen Weatherhill, that disparities of national laws regulating off-premises contracts did not really pose an obstacle to the functioning of the internal market and that in fact it is not economic rationale or "market-building" that is behind the approximation of off-premises legislations of Member States, but rather the will to express 'a unanimous political preference for the development of a legislative programme of consumer protection at a time when

\footnotetext{
${ }^{72}$ Recital 3 Directive 85/577/EEC

${ }^{73}$ Twigg-Flesner, C., "Good-Bye Harmonisation by Directives, Hello Cross-Border only Regulation?" - A way forward for EU Consumer Contract Law', 7 European Review of Contract Law, Issue 2 (2011), p. 235-256., p. 238.

${ }^{74}$ Ibid, p. 239.
} 
the Treaty conferred no relevant competence in the field. ${ }^{75}$ Indeed, by way of reference to Council Resolutions of 1975 and 1981 on consumer protection and information policy, Recital 5 of the Directive states that

'the special feature of contracts concluded away from the business premises of the trader is that as a rule it is the trader who initiates the contract negotiations, for which the consumer is unprepared or which he does not expect; whereas the consumer is often unable to compare the quality and price of the offer with other offers; whereas this surprise element generally exists not only in contracts made at the doorstep but also in other forms of contract concluded by the trader away from his business premises'.

Thus, the Directive, concludes Weatherhill, was created in an effort to express Member States' unanimous will in the Council - as required by Article 100 of the Treaty establishing the European Economic Community - to develop a consumer policy, and not so much to promote the internal market. For that reason, Weatherhill claims that 'the Doorstep Selling Directive deserves to be rated as one of the most vulnerable to the allegation that it lacks constitutional validity ${ }^{76}$ and as such, the Directive is a landmark example of unconvincing harmonisation and a form of "competence creep". ${ }^{77}$

This assessment concerning the inappropriate use of the internal market clause was underpinned by the CJEU's later judgment in Tobacco advertising $I{ }^{78}$ in which the constitutional limits of the internal market clause and the boundaries of the Community's competence to harmonise laws have been defined. In its judgment, the Court annulled Directive 98/43/EC relating to the advertising and sponsorship of tobacco products, ruling that the internal market clause (Article 100a EC Treaty at the time) did not provide an appropriate legal basis for the Directive. The Court observed that the Community legislature cannot rely on the need to eliminate obstacles to the free movement of advertising media and the freedom to provide services or on the need to eliminate distortions of competition, either in the advertising sector or in the tobacco products sector, in order to adopt the Directive on the basis of the internal market provision. ${ }^{79}$

Despite all the controversies surrounding the choice of legal basis, the Doorstep Selling Directive fits into the mainstream of consumer protection measures adopted in the wake of European consumer policy in terms of the choice of its legal basis. A further

\footnotetext{
${ }^{75}$ Weatherhill, S., EU Consumer Law and Policy (Elgar European Law, Cheltenham, UK - Northampton, MA, 'USA, 2005) p. 81.

${ }^{76}$ Weatherhill, S., EU Consumer Law and Policy, p. 94.

${ }^{77}$ Ibid, p. 71-72.

${ }^{78}$ Case C-376/98 Tobacco Advertising I [2000] ECR I-8419

${ }^{79}$ Ibid., para. 99.
} 
common feature these directives share is the degree to which they harmonise national laws, as will be seen in the following section.

\subsubsection{Minimum Harmonisation and Barriers to Trade}

As the bulk of EU consumer law between 1985 and 2002, ${ }^{80}$ the Doorstep Selling Directive lays down a level of minimum harmonisation, allowing Member States with a higher standard of consumer protection to retain extra rights for consumers, thereby ensuring a certain level of legal heterogeneity between the Member States. Minimum harmonisation, in the words of Micklitz, was the "magic formula" at the time which appeased the interests of both Member States and the Commission, allowing the European legislature to set minimum standards, but did not hold Member States back from introducing higher levels of protection. ${ }^{81}$

A key feature of the minimum harmonisation was a measure enshrined in the last recital of the Doorstep Selling Directive, namely the competence of Member States to maintain or introduce more stringent consumer protection measures. The measure was confirmed in Buet ${ }^{82}$ where banning the sale of educational material through doorstep selling was not deemed to be in violation of the principle of free movement by the Court of Justice, given that the Directive is of minimum harmonisation nature and because the withdrawal right provided by the Directive did not offer sufficient protection. The ruling in Buet was followed by a string of judgments passed by the CJEU concerning direct selling restrictions for the purposes of consumer protection, as will be described in the following chapter's sub-section 3.3.5.1. concerning trading bans.

\subsubsection{Scope of Application}

The Doorstep Selling Directive governed contracts concluded between businesses and consumers only. The notion of "consumer" was defined as a natural person who, in transactions covered by the Directive, is acting for purposes which can be regarded as outside his trade or profession; "trader" meant a natural or legal person who, for the transaction in question, acts in his commercial or professional capacity, and anyone acting in the name or on behalf of a trader. ${ }^{83}$ The Directive applied to contracts under which a trader supplies goods or services to a consumer and which were conclud-

\footnotetext{
${ }^{80}$ Twigg -Flesner, C., 7 European Review of Contract Law, Issue 2 (2011), p. 235-256., p. 239.

${ }^{81}$ Micklitz, H-W., 'Do Consumer and Businesses Need a New Architecture of Consumer Law? A Thought Provoking Impulse', EUI Working Papers, Law 2012/23, Department of Law, available at http://papers.ssrn.com/sol3/papers.cfm?abstract_id=2169226 (last visited 17 June 2015), p. 9.

${ }^{82}$ Summary of judgment - Case C-382/87 Buet v Ministre Public [1989] ECR 1235

${ }^{83}$ Article 2 Directive 85/577/EEC
} 
ed during an excursion organised by the trader or during the unsolicited visit of the trader to the consumer's home or workplace. ${ }^{84}$ The Directive also applied to contracts for the supply of goods or services other than those concerning that for which the consumer requested the visit of the trader, provided that when he requested the visit the consumer did not know, or could not reasonably have known, that the supply of those other goods or services formed part of the trader's commercial or professional activities. ${ }^{85}$ Conclusively, contracts where the consumer expressly requested the trader's visit were not covered by the Directive due to the fact that these transactions are lacking the necessary surprise element, which is an important difference to the later adopted Consumer Rights Directive that covers both unsolicited and solicited visits.

The Directive did not apply to contracts for the construction, sale and rental of immovable property, ${ }^{86}$ the supply of foodstuffs or beverages or other goods intended for current consumption in the household and supplied by regular roundsmen, ${ }^{87}$ contracts based on a trader's catalogue, ${ }^{88}$ insurance contracts ${ }^{89}$ and contracts for securities. ${ }^{90}$ These were all exempted from the scope of the Doorstep Selling Directive.

Furthermore, the Directive provided for the possibility of a de minimis exemption of 60 ECU - Member States could exempt contracts from the scope of the Directive for which the payment to be made by a consumer did not exceed the 60 ECU threshold. The rationale behind the option to exempt contracts from the protection of the Directive is that for low monetary value contracts, the legislator may simply not want to interfere with the contractual freedom of the parties. Thanks to the minimum harmonisation nature of the Directive, some Member States (e.g. Denmark, France and Hungary) did not introduce thresholds at all, whereas others set various thresholds within their own national laws (e.g. the Czech Republic had a EUR 50 threshold, the Netherlands a EUR 34 threshold, Sweden a SEK 300 (EUR 35) threshold, etc.).

\footnotetext{
${ }_{84}$ Article 1(1) Directive 85/577/EEC

${ }^{85}$ Article 1(2) Directive 85/577/EEC

${ }^{86}$ Article 3 lit. a) Directive 85/577/EEC

${ }^{87}$ Article 3 lit. b) Directive 85/577/EEC

${ }^{88}$ Article 3 lit. c) Directive 85/577/EEC provided that all three of the following conditions are met: (i) the contract is concluded on the basis of a trader's catalogue which the consumer has a proper opportunity of reading in the absence of the trader's representative, (ii) there is intended to be continuity of contact between the trader's representative and the consumer in relation to that or any subsequent transaction, (iii) both the catalogue and the contract clearly inform the consumer of his right to return goods to the supplier within a period of not less than seven days of receipt or otherwise to cancel the contract within that period without obligation of any kind other than to take reasonable care of the goods

${ }^{89}$ Article 3 lit. d) Directive 85/577/EEC

${ }^{90}$ Article 3 lit. e) Directive 85/577/EEC
} 


\subsubsection{Withdrawal Right}

The Doorstep Selling Directive did not regulate the content of contracts falling under its scope. In line with the contemporary practice, the Directive did not prescribe detailed information provision obligations, it merely emphasised the introduction of specific requirements, such as the right to withdraw. ${ }^{91}$ Because of the surprise element, the Directive ensured consumers an enhanced level of protection through the so-called cooling-off period: in the pre-contractual phase, the trader was obliged to present information to consumers on their right of withdrawal, whereas, following the conclusion of the contract, the consumer was entitled to renounce the effect of his undertaking by sending a notice within a minimum of seven days from receipt by consumer of the written notice of their right of cancellation, in accordance with the procedure laid down by national law. ${ }^{92}$ Thanks to the minimum harmonisation character of the Directive, the length of the cooling-off period differed from Member State to Member State. In Malta and Slovenia, consumers had 15 calendar days within which they could rescind from the contracts; in Cyprus, the Czech Republic, Denmark, Estonia, Finland, Latvia, Portugal, Sweden and Germany consumers enjoyed 14 calendar-day cooling-off periods, whereas in Austria, Belgium, Bulgaria, France, Greece, Spain, Ireland, Italy, Lithuania, Luxembourg, the Netherlands, Slovakia, the UK, Poland and Hungary consumers have had shorter withdrawal periods (between 7 and 10 working days). ${ }^{93}$

The rationale for providing consumers with enhanced rights when concluding contracts negotiated away from business premises - as explained by the Doorstep Selling Directive - is that it is the 'traders who initiate the contract negotiations, for which the consumer is unprepared or which he does not expect; whereas the consumer is often unable to compare the quality and price of the offer with other offers; whereas this surprise element generally exists not only in contracts made at the doorstep but also in other forms of contract concluded by the trader away from his business premises. ${ }^{\prime 94}$

\footnotetext{
${ }^{91}$ Micklitz, H-W., 'Do Consumer and Businesses Need a New Architecture of Consumer Law? A Thought Provoking Impulse', EUI Working Papers, Law 2012/23, Department of Law, available at http://papers.ssrn.com/sol3/papers.cfm?abstract_id=2169226 (last visited 17 June 2015), p. 5.

92 Article 5 Directive 85/577/EEC

${ }^{93}$ European Commission, The Proposal For A Directive On Consumer Rights: Impact on Level of National Consumer Protection Comparative Table (Draft), Brussels 9 October 2009, p. 7., http://ec.europa.eu/consum ers/rights/docs/comparative_table_en.pdf (last visited 17 September 2014)

${ }^{94}$ Recital 5 Directive 85/577/EEC
} 
The lex specialis for off-premises contracts is thus meant to compensate for the trader's situational and temporary monopoly, ${ }^{95}$ and remedy the information asymmetry and the potentially irrational consumer choice.

The situational and temporary monopoly ${ }^{96}$ of the trader with regard to doorstep selling is confined to the spatially limited place of consumers ${ }^{97}$ whereas the time dimension - which may be limited to only a few minutes - is beneficial for the trader as, within a certain timeframe, the consumer has to make a choice when competitors are unable or are at least severely limited to compete within the monopoly space. ${ }^{98}$ The cooling-off period limits this monopoly and allows for consumers to compare the offer or purchase with other available alternatives and rescind, if deemed necessary.

Information asymmetry in this context means the informational deficits on the consumer's side - traders are bound to have more information in the pre-contractual phase, particularly as regards the hidden characteristics of products. Information can be collected after the contract is concluded so as to compensate the information asymmetry and to allow the consumer to inform himself more sufficiently and, if based on this extended knowledge, he considers the contract he had concluded less beneficial, he can withdraw from it within the cooling-off period.

The potentially irrational consumer choice may be the result of unfair persuasion ${ }^{99}$ in that the salesperson might insert psychological pressure on consumers to purchase the product.

\subsubsection{Lack of Horizontal Direct Effect}

As most directives, the Doorstep Selling Directive did not have horizontal direct effect, so that individuals could therefore not rely on provisions of the Directive directly in actions against each other. The lack of horizontal direct effect was ruled in Faccini Dori v. Recreb. ${ }^{100}$ The case concerned an Italian individual, Ms. Faccini Dori, who purchased an English language course away from the trader's business premises, at a train station in Milan and later wished to exercise her withdrawal right. As Italy had not implement-

\footnotetext{
95 The two dimensions of monopoly: (1) space and (2) time have been developed by Lele in Lele M. M., Monopoly rules: How to Find, Capture, and Control the World's Most Lucrative Markets in any Business ((Paperback ed.), Kogan Page., London, 2007), p. 45.

${ }^{96}$ Lele, M. M., Monopoly rules: How to Find, Capture, and Control the World's Most Lucrative Markets in any Business, p. 45.

${ }^{97}$ Hoeppner, S., 'The Unintended Consequence of Doorstep Consumer Protection: Surprise, Reciprocation, and Consistency', SSRN, SSRN-ID: 2057605, May 2012, p. 5-6., http://papers.ssrn.com/sol3/papers.cfm? abstract_id=2057605 (last visited 17 September 2014)

${ }^{98}$ Ibid., p. 6.

${ }^{99}$ Eisenberg, M.A., 'The bargain principle and its limits', 95 Harvard Law Review (1982), p. 741-801, p. 773.

${ }^{100}$ Case C-91/92 Faccini Dori v. Recreb [1994] ECR I-3325
} 
ed the Directive into its national law at the time, consumers were not entitled to withdraw from off-premises contracts under Italian law. The claimant therefore attempted to rely directly at the Doorstep Selling Directive against a private body, Recreb, yet, the Court - reverting to Marshall ${ }^{101}$ - ruled that the Directive cannot be directly effective in such circumstances. However, under the Francovich doctrine, Ms. Dori was entitled to gain compensation from the Italian state.

\subsubsection{The Consumer Rights Directive}

As of 13 June 2014, the Doorstep Selling Directive was repealed by the 2011/83/EU Directive on consumer rights that brought about significant changes in the field of consumer law related to direct selling.

The Directive is the result of an ambitious legislative endeavour to create a coherent horizontal directive covering the entire field of consumer protection. The Commission's original proposal was initially aimed at the establishment of a fully harmonised retail internal market by merging eight ${ }^{102}$ existing directives into one single set of rules. The number was reduced to four directives on 8 October $2008,{ }^{103}$ which were: Directive 99/44/EC on the sale of consumer goods and guarantees, Directive 93/13/EC on unfair terms in consumer contracts, Directive 97/7/EC on distance selling and Directive $85 / 577 /$ EC to protect the consumer in respect of contracts negotiated away from business premises. However, at a relatively late stage of the legislative procedure, because of the intense political battle the initiative's intended full harmonisation nature had stirred between the Commission and the Member States, the general provisions have been taken out from the proposal which ended up becoming a horizontal harmonising instrument for the direct selling and the distance selling sector. More specifically, following extensive discussions, the Council finally agreed on a general approach for consumer rights on 10 December 2010 which was a shorter and narrower version of the original proposal. ${ }^{104}$ The Council's draft fully harmonised the conditions on consumer information and the right of withdrawal in distance and off-premises contracts between traders and consumers, but would not have prevented Member States from offering

\footnotetext{
${ }^{101}$ Case C-152/84 Marshall v Southampton and South West Area Health Authority [1986] ECR I-4367

${ }^{102}$ Directive 85/577 on doorstep selling, Directive 90/314 on package travel, Directive 93/13 on unfair terms in consumer contracts, Directive $94 / 47$ on timeshare, Directive $97 / 7$ on distance contracts, Directive 98/6 on price indications, Directive $98 / 27$ on injunctions and Directive $99 / 44$ on the sale of consumer goods and associated guarantees.

${ }^{103}$ Proposal for a Directive Of The European Parliament And Of The Council on consumer rights $\{$ SEC(2008) 2544\}\{SEC(2008) 2545\}\{SEC(2008) 2547\} COM(2008) 614 final, 2008/0196 (COD), Brussels 8.10.2008.

${ }^{104}$ Council of the European Union: Council agrees on general approach for consumer rights, Brussels, 24 January 2011, 5426/11, PRESSE 7
} 
consumers contractual arrangements that would have gone beyond the letter of law as enshrined in the Directive. ${ }^{105}$ The European Parliament, however, initially rejected the Council's draft and planned a vote on a revised version of the original proposal, which still aimed to replace the aforementioned four directives, but would have entitled Member States to adopt or maintain more protective rules concerning unfair contract terms and consumer sales contract ${ }^{106}$ rendering the positions of the Council and the EP very similar. The European Parliament eventually decided not to vote on this proposal but instead to attempt to reach an inter-institutional agreement. ${ }^{107} \mathrm{~A}$ consensus regarding the text of the Directive was finally struck in the summer of 2011, combining the Council's technique to limit the impact of the proposal with that of the EP. ${ }^{108}$

The reason why the Directive was introduced was to both secure a high level of consumer protection throughout the entire EU as well as to protect the competitiveness of enterprises aiming to promote the internal market as an area without internal frontiers, in which the free movement of goods and services and freedom of establishment are ensured. ${ }^{109}$ Looking at the justification concerning the current field of enquiry specifically, Recital 5 states that:

'The cross-border potential of contracts negotiated away from business premises (direct selling) is constrained by a number of factors including the different national consumer protection rules imposed upon the industry. Compared with the growth of domestic direct selling over the last few years, in particular in the services sector, for instance utilities, the number of consumers using this channel for cross-border purchases has remained flat. Responding to increased business opportunities in many Member States, small and medium-sized enterprises (including individual traders) or agents of direct selling companies should be more inclined to seek business opportunities in other Member States, in particular in border regions. Therefore the full harmonisation of consumer information and the right of withdrawal in distance and off-premises contracts will contribute to a high level of consumer protection and a better functioning of the business-to-consumer internal market.'

The overall Internal Market objective is not surprising as it is a characteristic of community private law, according to Hesselink, yet he claims that a striking feature of the

\footnotetext{
${ }^{105}$ Ibid. p. 1.

${ }^{106}$ Cauffman, C.,'The Consumer Rights Directive - Adopted', 19 Maastricht Journal of European and Comparative Law, 19(1), (2012), p. 212-218, p. 212.

${ }^{107}$ Ibid.

${ }^{108}$ Ibid.

${ }^{109}$ Recital 4 Directive 2011/83/EU
} 
Directive is its instrumental nature ${ }^{110}$ in the creation of a "level playing field". The appointed legal basis and harmonisation of national laws as the means to achieve the establishment of the Internal Market renders the Directive instrumental (at least as long as the purpose of harmonisation is accomplished) and as such, different from national contract law as it purposes to provide a 'just solution to disputes between private parties'. ${ }^{111}$

The Consumer Rights Directive is a significantly more detailed legal instrument than its predecessor, the aforementioned Doorstep Selling Directive, in that it also regulates substantial elements of the transactions falling under its scope of application. The present section will only assess the Directive's provisions concerning direct selling and solely from a legal perspective - the political context and implications thereof will be introduced in the following chapter (chapter IV) devoted to the examination of the industry lobby of the CRD.

\subsubsection{Legal Basis}

The legal basis of the Directive of Consumer Rights is Article 114 TFEU on the approximation of the provisions laid down by law, regulation or administrative action in Member States which have as their object the establishment and functioning of the internal market. ${ }^{112}$ Insofar as the internal market is concerned, the European Union has exclusive competence in the establishment of competition rules (Art. 3(1) lit. b) TFEU) and shared competence in other areas, such as the field of consumer law (Art. 4(1) lit. f) TFEU). Until the European Union has made use of its competence, Member States are free to legislate and adopt legally binding acts according to Article 2(2) TFEU.

If and when the EU does exercise its competence, Member States are no longer free to regulate matters falling under the harmonised areas, unless European law provides otherwise. In order to promote the interests of consumers and to ensure a high level of consumer protection, Article 169(2) TFEU stipulates that the Union shall contribute to these objectives through (a) 'measures adopted pursuant to Article 114 in the context of the completion of the internal market', as well as (b) measures to support, supplement and monitor the policy pursued by the Member States. Measures taken to support, supplement and monitor the policy pursued by the Member States (pursuant to Art. 169 (2)

\footnotetext{
${ }^{110}$ Hesselink, M. W., 'Towards a Sharp Distinction between B2B and B2C? On Consumer, Commercial and General Contract Law after the Consumer Rights Directive', 18 European Review of Private Law, No. 18 (2010), p. 57-102, Also available at the SSRN website at http://papers.ssrn.com/sol3/papers.cfm?abstract_id=1416126, p. 10-11.

${ }^{111}$ Ibid.

${ }^{112}$ Article 114 TFEU
} 
lit. b)), - so not in the context of the internal market - shall be adopted by ordinary legislative procedure and shall be of minimum harmonisation (Art. 169(4)). Where harmonisation is aimed at the establishment of the internal market, the nature of harmonisation may be minimum or maximum, depending on the choice of the European Union, but the Commission must take as a base a high level of consumer protection (under Art. 114(3) TFEU). ${ }^{113}$

Loos suggests that the result is that - although the Commission's rhetoric may seem otherwise -, 'it is not so much the interests of consumers that are being protected but rather those of competitors'. ${ }^{114}$ Loos claims this observation is substantiated by the experience with the UCPD, where, looking at the first cases that have been adjudicated by the CJEU, it was competitors and not consumers or consumer organisations that have made much use of the Directive. ${ }^{115}$

On the other hand, insofar as the Commission is concerned, it is clear that the preference for the choice of Article 114 TFEU as a legal basis over Article 168 TFEU is the fact that it can only introduce maximum harmonisation measures and remove substantial barriers to trade and/or consumer contracts cross-border through the choice of Article 114 TFEU. ${ }^{116}$ The conclusion that Loos draws is that the internal market dimension is always (over-)emphasised in the Commission proposals, creating the risk that 'certain consumer protection aspects are simply overlooked or overpowered by the political or legislative need to promote the further development of the internal market'. ${ }^{117}$

\footnotetext{
${ }^{113}$ Loos, M. B. M., 'Full harmonisation as a regulatory concept and its consequences for the national legal orders. The example of the Consumer rights directive', Centre for the Study of European Contract Law Working Paper Series No. 2010/03, available at http://papers.ssrn.com/sol3/papers.cfm?abstract_id=1639436 (last visited: 17 June 2015), p. 4.

${ }^{114}$ Ibid.

${ }^{115}$ Ibid.

${ }^{116}$ Loos, M. B. M., 'Full harmonisation as a regulatory concept and its consequences for the national legal orders. The example of the Consumer rights directive', Centre for the Study of European Contract Law Working Paper Series No. 2010/03, available at http://papers.ssrn.com/sol3/papers.cfm?abstract_id=1639436 (last visited: 17 June 2015), p. 4.; Cf. Twigg-Flesner, C., 'No sense of purpose or direction? The modernisation of European Consumer Law', 2 European Review of Contract Law 2007/2, p. 206-207.

${ }^{117}$ Loos, M. B. M., 'Full harmonisation as a regulatory concept and its consequences for the national legal orders. The example of the Consumer rights directive', Centre for the Study of European Contract Law Working Paper Series No. 2010/03, available at http://papers.ssrn.com/sol3/papers.cfm?abstract_id=1639436 (last visited: 17 June 2015), p. 4-5. Furthermore, in footnote 19, Loos cites 'Howells, G. 'The Scope of European Consumer Law', 3 European Review of Contract Law (2005), p. 370; Twigg-Flesner, C., European Union Private Law, (Cambridge, Cambridge University Press, 2010), p. 5-6; Tonner, K. and Tamm, M., 'Der Vorschlag einer Richtlinie über Rechte der Verbraucher und seine Auswirkungen auf das nationale Verbraucherrecht', JuristenZeitung 2009, p. 282. See also Unberath, H. and Johnston, A., 'The double-headed approach of the ECJ concerning consumer protection', Common Market Law Review 2007, p. 1244, who argue that in a Community which is market-driven, consumer protection will always be of an auxiliary nature and a corollary to the internal market, relevant only as a ground to justify rules that restrict trade.'
} 
Tying in with this line of thought, doubts concerning the validity of this legal basis and the convenient political use of the conferral conveyed by Art.114 TFEU have already been expressed concerning the Doorstep Selling Directive by Stephen Weatherill. Against the backdrop of the rise of the qualified majority voting in the Council and the Tobacco Advertising I judgment, it was once more underlined by Weatherill that the EU's limited competence does matter both in principle as well as in practice. Nevertheless, the Court's later ruling in Vodafone ${ }^{118}$ has set a considerably lower constitutional threshold thanks to which the Consumer Rights Directive would likely pass any constitutional challenge. ${ }^{119}$

The constitutional test established by the Court in Vodafone is as follows:

'According to consistent case-law the object of measures adopted on the basis of Article 95(1) EC must genuinely be to improve the conditions for the establishment and functioning of the internal market [...] While a mere finding of disparities between national rules and the abstract risk of infringements of fundamental freedoms or distortion of competition is not sufficient to justify the choice of Article 95 EC [Article 114 TFEU] as a legal basis, the Community legislature may have recourse to it in particular where there are differences between national rules which are such as to obstruct the fundamental freedoms and thus have a direct effect on the functioning of the internal market [...] or to cause significant distortions of competition.' ${ }^{120}$

The Court's requirements concerning the sufficient justification of legal acts - the intention to genuinely improve the internal market, the obstruction of fundamental freedoms and its direct effect on the functioning of the internal market or the significant distortion of competition - can easily be met and have thus considerably lowered the bar for constitutional validity for the European legislature. The CJEU's increased acceptance of justification claims made by the European legislature point to the Court's general reinforcement of the legislative output and, in the present case, lead one to believe that the Consumer Rights Directive too would survive any constitutional challenge, however weak the European legislator's justification and the choice of legal basis may appear. ${ }^{121}$

\footnotetext{
${ }^{118}$ Case C-58/08 Vodafone, O2 et al v. Secretary of State [2010] ECR I-4999

${ }^{119}$ Weatherill, S., 'The Consumer Rights Directive: How and why a quest for coherence has (largely) failed', 49 Common Market Law Review, (2012) p. 1279-1318., p. 1307-1308.

${ }^{120}$ Case C-58/08 Vodafone, O2 et al v. Secretary of State [2010] ECR I-4999, para. 32.

${ }^{121}$ Weatherill, S., 49 Common Market Law Review (2012), p. 1307-1308.
} 


\subsubsection{Degree of Harmonisation}

With only a few exceptions, ${ }^{122}$ Article 4 of the Directive provides for the maximum harmonisation of national laws for the common aspects of direct selling and distance selling contracts in an effort to enhance cross-border trade in both sectors ${ }^{123}$ as well as to combat certain disparities such as disproportionate legal fragmentation that create significant barriers to the internal market ${ }^{124}$ and to thereby considerably increased legal certainty for consumers and traders, ${ }^{125}$ argues the European legislator in the Directive's recitals.

The full harmonisation approach reflects the change of legal paradigm and the intention to establish a more coherent and systematised structure of European contract law, instead of the isolated strands of rules created in the wake of European consumer policy. As indicated, the earlier trend in the field of consumer protection was to introduce measures of minimum harmonisation to approximate Member State laws. This made it easier for Member States to absorb European law by having only a limited impact on national regimes, whereby the implementation of minimum standards still provided Member States with the possibility to increase the level of protection within their own remits where European law was silent (this is referred to "goldplating"). ${ }^{126}$ Goldplating, at least in theory, held the potential to create even greater differences in Member State laws however, which meant that traders continued to have to deal with the administrative costs of compliance with different national regimes. ${ }^{127}$ While minimum harmonisation is clearly not desirable for businesses, it may be beneficial not only from a consumer perspective but also from the aspect of the evolution of (private) law as different preferences may lead to different solutions which could be considered a benefit, not a problem. ${ }^{128}$ Smits suggests jurisdictional competition has two advantages over centralised lawmaking: first, Member States can be seen as "experimenting laboratories" in that Member States' in order to find a solution matching the particular case of each Member State and enforce the probability of innovations and, secondly, because jurisdictional competition allows the satisfaction of diverging preferences. ${ }^{129}$

\footnotetext{
122 See below.

${ }^{123}$ Recital 5 Directive 2011/83/EU

${ }^{124}$ Recital 6 Directive 2011/83/EU

${ }^{125}$ Recital 7 Directive 2011/83/EU

${ }^{126}$ Loos, M. B. M., Centre for the Study of European Contract Law Working Paper Series No. 2010/03, p. 4-5.:

Twigg-Flesner, C., European Union Private Law, p. 4.

${ }^{127}$ Ibid.

${ }^{128}$ Smits, J. M., 'Mixed Jurisdictions: Lesson for European Harmonisation?', 12 Electronic Journal of Comparative Law, Nr. 1 (2008), p. 1.

${ }^{129}$ Ibid. p. 3
} 
Other authors claim that there is no evidence supporting the claim that maximum harmonisation is the best means to overcome perceived problems of legal fragmentation and increasing consumer confidence. ${ }^{130}$ As a matter of fact, Faure points out that is exactly the divergence of market condition which creates the conditions for interstate trade, ${ }^{131}$ not the uniformity thereof.

Furthermore, the reasons why consumers do not tend to shop online are often linked to practicalities such as language- or cultural barriers, national customs and preferences, differences in the system of taxation or the mere geographical distance between the trader and the consumer. ${ }^{132}$

Nonetheless, through the choice of maximum harmonisation, the presumption has been made that harmonisation of direct- and distance selling rules is a more sufficient tool in establishing the internal market in that consumers will have the same rights when shopping cross-border as in the Member State of their residence, whereas traders will have less compliance costs arising from the fragmentation of national laws in the EU. As many direct selling corporations are multinational companies operating in all or in a number of EU Member States, it is likely that full harmonisation (i.e. having to comply with a single set of rules only, instead of operating in the realm of various different regulatory systems) will decrease administrative and legal costs; furthermore, full harmonisation should also result in the abrogation of trade barriers (i.e. those that cannot be justified by the ordre public clause) which has been a longstanding interest of the industry.

As will be described later in the respective sections of the present chapter, the most important areas where a level of minimum harmonisation was introduced concern the personal scope of application, the possible exemptions from the Directive's scope of application, the specific information requirements and the so-called payment bans.

\footnotetext{
${ }^{130}$ Cf. Rott, P., Terryn, E., 'The proposal for a Directive on consumer rights: no single set of rules', 1 Zeitschrift für Europäisches Privatrecht (2009), p. 460.; Micklitz, H. W., Reich, N., 'Crónica de una muerte anunciada: the Commission proposal for a "directive on consumer rights"', Common Market Law Review 2009, p. 474-475. as cited by Loos, M. B. M., 'Full harmonisation as a regulatory concept and its consequences for the national legal orders. The example of the Consumer rights directive', Centre for the Study of European Contract Law Working Paper Series No. 2010/03, available at http://papers.ssrn.com/sol3/papers.cfm?abstract_id=1639436 (last visited: 17 June 2015), p. 9.

${ }^{131}$ Faure, M., 'Towards a maximum harmonisation of consumer contract law?', 4 Maastricht Journal of European and Comparative Law (2008), p. 440-441.

${ }^{132}$ See e.g. Cseres, K., Competition Law and Consumer Protection (Kluwer, The Hague, 2005), p. 233., Faure, M., 'Towards a maximum harmonisation of consumer contract law?', 4 Maastricht Journal of European and Comparative Law (2008), p. 438., Loos, M. B. M., 'Full harmonisation as a regulatory concept and its consequences for the national legal orders. The example of the Consumer rights directive', Centre for the Study of European Contract Law Working Paper Series No. 2010/03, p. 11.
} 


\subsubsection{Scope}

The Consumer Rights Directive governs contracts concluded between traders and consumers. ${ }^{133}$ "Consumer", under the Consumer Rights Directive, means any natural person, who -in contracts covered by the Consumer Rights Directive- is acting for purposes which are outside his trade, business, craft or profession. ${ }^{134}$ Micklitz has found that the concept of "consumer" is defined by European law in a negative way in general, through features that he does not have rather than positively and that, although EU law strives to harmonise substantive rules of consumer protection, it actually struggles to determine what falls under the personal scope of "consumers". ${ }^{135}$ The possibility for Member States to expand the term "consumer" within the limits of proportionality has been provided for by the CJEU in Buet, ${ }^{136}$ di Pinto ${ }^{137}$ and Doc Morris ${ }^{138}$ raising some issues concerning the exact definition of the term. ${ }^{139}$

The first debated area is whether only natural persons fall under the scope of "consumers" or if legal persons can also be included and, if so, whether commercial legal persons may also be considered consumers or only those that do not pursue commercial activities. While the CJEU denied legal persons the consumer status in Idealservice, ${ }^{140}$ Recital 13 of the Consumer Rights Directive 2011/83/EU stipulates that Member States may decide to extend the application of the rules of the Directive to legal persons or to natural persons who are not consumers within the meaning of the Directive, such as non-governmental organisations, start-ups or small and medium-sized enterprises. In Italy, Romania, Austria, Belgium, the Czech Republic, Denmark, Greece, Hungary, Slovakia and Spain legal persons can be treated as consumers, whereas German law only speaks of natural persons as consumers. ${ }^{141}$

\footnotetext{
${ }^{133}$ Article 1 Directive 2011/83/EU

${ }^{134}$ Article 2(1) Directive 2011/83/EU

${ }^{135}$ Micklitz, H-W., 'Do Consumer and Businesses Need a New Architecture of Consumer Law? A Thought Provoking Impulse', EUI Working Papers, Law 2012/23, Department of Law, available at http://papers.ssrn.com/sol3/papers.cfm?abstract_id=2169226 (last visited 17 June 2015), p. 24-25.

${ }^{136}$ Case C-382/87 R. Buet and Educational Business Services (EBS) v Ministère public [1989] ECR1235

${ }^{137}$ Case C-361/89 Criminal proceedings v Patrice Di Pinto [1991] ECR I-01189

${ }^{138}$ Case C-322/01 Deutcher Apothekenverband eV v 0800 DocMorris NV [2003] ECR I-14887

${ }^{139}$ Micklitz, H-W., 'Do Consumer and Businesses Need a New Architecture of Consumer Law? A Thought Provoking Impulse', EUI Working Papers, Law 2012/23, Department of Law, available at http://papers.ssrn.com/sol3/papers.cfm?abstract_id=2169226 (last visited 17 June 2015), p. 24-25.

${ }^{140}$ Joined cases C-541/99 and C-542/99 - Cape Snc v Idealservice Srl and Idealservice MN RE Sas v OMAI Srl [2001], ECR I-9049, para 16.

${ }^{141}$ Micklitz, H-W., 'Do Consumer and Businesses Need a New Architecture of Consumer Law? A Thought Provoking Impulse', EUI Working Papers, Law 2012/23, Department of Law, available at http://papers.ssrn.com/sol3/papers.cfm?abstract_id=2169226 (last visited 17 June 2015), p. 24-25.
} 
The second key question is focused on the distinction of commercial purposes versus non-commercial purposes. As per the definition enshrined in the Consumer Rights Directive, a "consumer" means any natural person who is acting primarily for purposes which are not related to his or her trade, business or profession, adhering to the general trend of the consumer acquis. However, Recital 17 of the Directive stipulates that, in the case of dual purpose contracts, where the contract is concluded for purposes partly within and partly outside the person's trade and the trade purpose is so limited as not to be predominant in the overall context of the contract, that person should also be considered as a consumer. The latter provision resembles Art.I.-1:105 (1) of the DCFR and reflects the Court's judgment in Gruber ${ }^{142}$ interpreting Article 13 of the Brussels Convention on Jurisdiction and the Enforcement of Judgments in Civil and Commercial Matters 1968 (Brussels Convention). In the case of a mixed contract the jurisdiction over consumer contracts applies only if the professional and commercial purpose is of such marginal importance that it plays a completely subordinate role in the business concerned. The Court has justified the strict interpretation of the Brussels Convention rules on jurisdiction over consumer contracts by way of reference to procedural efficiency. ${ }^{143} 144$

"Trader" means any natural person or any legal person, irrespective of whether privately or publicly owned, who is acting, including through any other person acting in his name or on his behalf, for purposes relating to his trade, business, craft or profession in relation to contracts covered by the Directive. ${ }^{145}$

Unlike the Doorstep Selling Directive that applied to unsolicited visits only (with the exception of solicited visits provided that when the consumer requested the visit, the consumer did not know, or could not reasonably have known, that the supply of those other goods or services formed part of the trader's commercial or professional activities), ${ }^{146}$ the scope of legislation has been extended to solicited visits by the Consumer Rights Directive, ${ }^{147}$ because, according to the reasoning of the legislator, the consumer may be subjected to psychological pressure and/or an element of surprise regardless of whether he had solicited the trader's visit. ${ }^{148}$ Furthermore, the distinction of requested

\footnotetext{
${ }^{142}$ Case C-464/01 Johann Gruber v Bay Way AG [2005] ECR I-439, para. 39-41.

${ }^{143}$ Ibid. para. 46.

${ }^{144}$ Micklitz, H-W., 'Do Consumer and Businesses Need a New Architecture of Consumer Law? A Thought Provoking Impulse', EUI Working Papers, Law 2012/23, Department of Law, available at http://papers.ssrn.com/sol3/papers.cfm?abstract_id=2169226 (last visited 17 June 2015), p. 24-25.

${ }^{145}$ Article 2(2) Directive 2011/83/EU

${ }^{146}$ Article 1 Directive 85/577/EEC

${ }^{147}$ Recital 21 Directive 2011/83/EU

${ }^{148}$ Ibid.
} 
and unsolicited visits proved problematic in practice, therefore this new rule is expected to enhance the level of protection for consumers regardless of whether the trader was expressly invited by the consumer or not.

The Consumer Rights Directive places more contracts outside its scope than the Doorstep Selling Directive originally did. Contracts for social services, ${ }^{149}$ healthcare, ${ }^{150}$ gambling, ${ }^{151}$ financial services, ${ }^{152}$ the creation, acquisition or transfer of immovable property, ${ }^{153}$ package travel, ${ }^{154}$ timeshare ${ }^{155}$ and contracts established by independent public-office holders ${ }^{156}$ are exempted from the scope of application of the Consumer Rights Directive as a result of a political compromise which required the restriction of the Directive's material scope in exchange for realising maximum harmonisation. An important change for direct selling was that contracts concluded with intended continuity on the basis of catalogues are covered by the Consumer Rights Directive, and are thus no longer exempted as was the case under the Doorstep Selling Directive. ${ }^{157}$

The exemption of financial services from the scope of the Directive will result in the "renationalisation" of direct selling rules ${ }^{158}$ in this particular field and is thus likely to create a gap in the structure of European consumer protection, as the Doorstep Selling Directive only allowed Member States to exclude certain financial services -namely insurance contracts and contracts on securities- ${ }^{159}$ from the scope of application of their doorstep selling laws. ${ }^{160}$

Similar to the de minimis exemption in the Doorstep Selling Directive, low monetary value contracts may be exempted from the scope of application in order to interfere less with parties' contractual freedom. In other words, Member States may decide not to apply the Directive or not to maintain or introduce corresponding national provisions to direct selling contracts for which the payment to be made by the consumer does not exceed EUR50. Member States may define a lower threshold value in their national legislation. ${ }^{161}$

\footnotetext{
${ }^{149}$ Article 3 lit. a) Directive 2011/83/EU

${ }^{150}$ Article 3 lit. b) Directive 2011/83/EU

${ }^{151}$ Article 3 lit. c) Directive 2011/83/EU

${ }^{152}$ Article 3 lit. d) Directive 2011/83/EU

${ }^{153}$ Article 3 lit. e) Directive 2011/83/EU

${ }^{154}$ Article 3 lit. g) Directive 2011/83/EU

${ }^{155}$ Article 3 lit. h) Directive 2011/83/EU

${ }^{156}$ Article 3 lit. i) Directive 2011/83/EU

${ }^{157}$ Article 3 (2) lit. c) Directive 85/577/EEC

${ }^{158}$ Rott, P., 'Renationalisation of direct selling - the impact of the new Consumer Rights Directive on financial services', 13 ERA Forum (2012), p. 35-44.

${ }^{159}$ Article 3(2) lit. d) and e) Directive 85/577/EEC

${ }^{160}$ Rott, P., 13 ERA Forum (2012), p. 35-37.

${ }^{161}$ Article 3(4) Directive 2011/83/EU
} 
Summary of Exemptions

\begin{tabular}{|c|c|c|}
\hline Exemption & Doorstep Selling Directive & Consumer Rights Directive \\
\hline Unsolicited transactions & No exemption - Article 1(1) & No exemption - Recital 21 \\
\hline Solicited transactions & $\begin{array}{l}\text { As a main rule exempt, but does } \\
\text { apply to solicited transactions, } \\
\text { provided that when the consumer } \\
\text { requested the visit the consumer did } \\
\text { not know, or could not reasonably } \\
\text { have known, that the supply of the } \\
\text { other goods or services formed part } \\
\text { of the trader's commercial or } \\
\text { professional activities. (Art.1(2)) }\end{array}$ & No exemption - Recital 21 \\
\hline De minimis exemption & $\begin{array}{l}\text { Minimum harmonisation measure, } \\
\text { below 60ECU transactions } \\
\text { (Art.3(1)) }\end{array}$ & $\begin{array}{l}\text { Minimum harmonisation measure, } \\
\text { below 50EUR transactions } \\
(\text { Art.3(4)) }\end{array}$ \\
\hline $\begin{array}{l}\text { Construction, sale, rental of } \\
\text { immovable property }\end{array}$ & Exempt (Art.3(2) lit.a)) & Exempt (Art.3(4) lit.e)) \\
\hline $\begin{array}{l}\text { Construction of new buildings, } \\
\text { reconstruction of existing buildings }\end{array}$ & No exemption & Exempt (Art.3(4) lit.f)) \\
\hline Supply for foodstuffs and beverages & Exempt (Art.3(2) lit.b)) & Exempt (Art.3(3) lit.j)) \\
\hline $\begin{array}{l}\text { Repeat transactions based on } \\
\text { catalogues }\end{array}$ & Exempt (Art.3(2) lit.c)) & No exemption \\
\hline Insurance & Exempt (Art.3(2) lit.d)) & Exempt (Art.3(3) lit.f)) \\
\hline Securities & Exempt (Art.3(2) lit.e)) & Exempt (Art.3(3) lit.f)) \\
\hline Financial services & No exemption & Exempt (Art.3(3) lit.f)) \\
\hline Social services & No exemption & Exempt (Art.3(3) lit.a)) \\
\hline Healthcare & No exemption & Exempt (Art.3(3) lit.b)) \\
\hline Gambling & No exemption & Exempt (Art.3(3) lit.c)) \\
\hline $\begin{array}{l}\text { Package travel, long-term holiday } \\
\text { services }\end{array}$ & No exemption & Exempt (Art.3(3) lit.g)) \\
\hline Timeshare & No exemption & Exempt (Art.3(3) lit.h)) \\
\hline $\begin{array}{l}\text { Contracts established by public office } \\
\text { holders }\end{array}$ & No exemption & Exempt (Art.3(3) lit.i)) \\
\hline Passenger transport services & No exemption & Exempt (Art.3(3) lit.k)) \\
\hline $\begin{array}{l}\text { Concluded by means of automatic } \\
\text { vending machines or automated } \\
\text { commercial premises }\end{array}$ & No exemption & Exempt (Art.3(3) lit.1)) \\
\hline $\begin{array}{l}\text { Concluded with telecommunications } \\
\text { operators }\end{array}$ & No exemption & Exempt (Art.3(3) lit.m)) \\
\hline
\end{tabular}




\subsubsection{Information Duties and Formal Requirements}

In order to remedy the information asymmetry between the consumer and the trader, Article 6 prescribes obligations for traders as regards consumer information for both distance and off-premises contracts. Information requirements as such are new features of the Consumer Rights Directive, compared to the Doorstep Selling Directive. The introduction of traders' information obligations as a measure of consumer protection is another indicator of the paradigmatic change in European consumer law. ${ }^{162}$ Micklitz has deemed the European legislative institutions to have framed information which traders are obliged to provide consumers in a reversal of the 'buyer/consumer beware' principle and sees the obligation to inform a continuous development which can be clearly proven through the comparison of the Doorstep Selling Directive and the CRD. ${ }^{163}$

Under Article 6(1), the trader shall inform the consumer of the essential elements of the contract such as the main characteristics of the goods and services, ${ }^{164}$ the identity and address of the trader, ${ }^{165}$ the total price of the goods ${ }^{166}$ or the right of withdrawal, ${ }^{167}$ etc.

Concerning information requirements, the Directive entails two degrees of harmonisation: for the provision of general information (Article 6 (1)-(6)), the Directive provides for full harmonisation, whereas under Article 6(8), Member States are allowed to introduce additional information requirements in accordance with the Directive - thus, regarding more specific information duties, a minimum level of harmonisation has been introduced.

It is the trader's formal obligation with respect to off-premises contracts to give the information provided for in Article 6(1) to the consumer on paper or, if the consumer agrees, on another durable medium. ${ }^{168}$ As was clarified in the course of the legislative procedure, durable medium includes e-mails too - therefore, information provision obligations can be fulfilled electronically, with the consent of the consumer. Information must be legible and in plain, intelligible language. ${ }^{169}$ The trader is also obligated to pro-

\footnotetext{
${ }^{162}$ Micklitz, H-W., 'Do Consumer and Businesses Need a New Architecture of Consumer Law? A Thought Provoking Impulse', EUI Working Papers, Law 2012/23, Department of Law, available at http://papers.ssrn.com/sol3/papers.cfm?abstract_id=2169226 (last visited 17 June 2015), p. 5.

${ }^{163}$ Ibid., p. 5.

${ }^{164}$ Article 6 (1) lit. a) Directive 2011/83/EU

${ }^{165}$ Article 6 (1) v lit. b)-c) Directive 2011/83/EU

${ }^{166}$ Article 6 (1) lit. e) Directive 2011/83/EU

${ }^{167}$ Article 6 (1) lit. h) Directive 2011/83/EU

${ }^{168}$ Durable medium, as provided for by Recital 23 of the Directive, should enable the consumer to store the information for as long as it is necessary for him to protect his interests stemming from his relationship with the trader. Such media should include in particular paper, USB sticks, CD-ROMs, DVDs, memory cards or hard disks of computers as well as e-mails.

${ }^{169}$ Article 7 Directive 2011/83/EU
} 
vide the consumer with a copy of the signed contract or a confirmation thereof on paper or another durable medium.

The Directive provides for an exception from the maximum harmonisation nature of the general provisions: under Article 7(4), with respect to off-premises contracts where the trader is providing reparatory or maintenance services for which the payment does not exceed EUR200, traders may have more limited formal requirements to fulfil, should the Member State decide to apply this specific sub-paragraph.

\subsubsection{Withdrawal Right}

The Consumer Rights Directive has brought about important changes relating to the regulation of the cooling-off period. The length of the cooling-off period is fully harmonised in all Member States and was extended to a uniform length of 14 days for both direct selling and distance selling contracts. ${ }^{170}$ The withdrawal period commences on the day of the conclusion of the contract in case of services contracts, whereas for the sale of goods contracts, the withdrawal period begins on the day the consumer acquires physical possession of the product. ${ }^{171}$ Should the trader fail to inform consumers of their right to withdraw at key stages of the sales process, the withdrawal period is further extended by potentially up to a year. ${ }^{172}$ This latter provision can be considered to be the clarification or the codification of the Heininger ${ }^{173}$ judgment that restricted the unlimited right of withdrawal to one year in the event of lacking instruction. ${ }^{174}$

Exemptions from the right of withdrawal are governed by Article 16 of the Directive. The main exemptions for service contracts are services that have been fully provided if the performance has begun with the consumer's prior express consent and with the acknowledgement that he will lose his right of withdrawal once the service is fully provided; ${ }^{175}$ whereas in the case of sale of goods contracts there are a number of exemptions, such as the supply of goods which are liable to deteriorate or expire rapidly ${ }^{176}$ or

\footnotetext{
${ }^{170}$ Article 11 Directive 2011/83/EU

${ }^{171}$ Article 9(2) Directive 2011/83/EU

${ }^{172}$ Article 10 Directive 2011/83/EU

${ }^{173}$ Case C-481/99 Georg Heininger and Helga Heininger v. Bayerische Hypo- und Vereinsbank AG [2001] ECR I-9945

${ }^{174}$ Micklitz, H-W., 'Do Consumer and Businesses Need a New Architecture of Consumer Law? A Thought Provoking Impulse', EUI Working Papers, Law 2012/23, Department of Law, available at http://papers.ssrn. com/sol3/papers.cfm?abstract_id=2169226 (last visited 17 June 2015), p. 10.

${ }^{175}$ Article 16 lit. a) Directive 2011/83/EU

${ }^{176}$ Article 16 lit. d) Directive 2011/83/EU
} 
the supply of sealed goods which are not suitable for return due to health protection or hygiene reasons and were unsealed after delivery, ${ }^{177}$ etc.

Consumers can exercise their withdrawal right with the use of a common withdrawal form as set out in Annex I(B) of the Directive or, alternatively, by making any unequivocal statement setting out the consumer's decision to withdraw from the contract.

Traders are obliged to reimburse all payments received from the consumer, including, where applicable, the costs of delivery, under Art. 13(1). The consumer shall only bear the direct cost of returning the goods unless the trader has agreed to bear them or the trader failed to inform the consumer that the consumer has to bear them. In the case of off-premises contracts where the goods have been delivered to the consumer's home at the time of the conclusion of the contract, the trader shall at his own expense collect the goods if, by their nature, those goods cannot normally be returned by post, according to Art. 14(1).

\subsubsection{Payment Bans}

Under Article 9(3) of the Consumer Rights Directive, already existing payment bans may be maintained by Member States. In practical terms this exemption from the maximum harmonisation nature of the Directive means that already existing national legislation prohibiting the trader from collecting the payment from the consumer during the given period after the conclusion of the contract may be kept in force. This provision is relevant in case of Belgium, Bulgaria, France and Greece where payments can only be collected after the withdrawal period has expired. In these Member States, traders may not collect payments at the time the contract is concluded, but have to wait until the withdrawal period expires and then collect the payment.

\subsubsection{Ancillary Contracts}

The Consumer Rights Directive contains a new rule on ancillary contracts meaning that if the consumer exercises his right of withdrawal from a distance or an off-premises contract, any ancillary contracts shall be automatically terminated. ${ }^{178}$ This provision was not enshrined in the Doorstep Selling Directive and in fact represents a move away from the CJEU's judgment in Schulte ${ }^{179}$ where the Court ruled that the Directive does not contain a rule on the automatic cancellation of ancillary contracts when the direct sell-

\footnotetext{
${ }^{177}$ Article 16 lit. e) Directive 2011/83/EU

${ }^{178}$ Article 15 Directive 2011/83/EU

${ }^{179}$ Case C-350/03 Elisabeth Schulte, Wolfgang Schulte v Deutsche Bausparkasse Badenia AG [2005] ECR I09215
} 
ing contract is cancelled, nor does it provide a basis for the assumption that such a rule is implied. ${ }^{180}$

\subsection{Fair Trading Law and Direct Selling}

Following the examination of consumer protection law concerning direct selling, the second part of this legal overview deals with fair trading law. Rules of competition will be examined as applying to $\mathrm{B} 2 \mathrm{C}$ transactions, as regulated by the Directive on Unfair Commercial Practices as well as to $\mathrm{B} 2 \mathrm{~B}$ relations, as governed by the Misleading and Comparative Advertising Directive.

\subsubsection{Fair Trading Law in Business-to-Consumer Relations: the Unfair}

\section{Commercial Practices Directive}

\subsubsection{Purpose and Legal Basis}

The Directive on Unfair commercial practices (UCPD) regulates the fairness of trade law in relation to advertisements addressed to consumers. Adopted on 11 May 2005, the Unfair Commercial Practices Directive concerns unfair business-to-consumer commercial practices in the internal market. The Directive aims to combat legal uncertainty resulting from disparities of the internal market and to thereby establish a high level of consumer protection. ${ }^{181}$ The purpose -as expressed in Article 1- is the achievement of a high level of consumer protection in order to contribute to the establishment of the internal market. The Directive is based on Article 114 TFEU (ex-Article 95 TEC).

While economic interests of consumers are protected directly, legitimate businesses are protected only indirectly from their competitors: ${ }^{182}$ at the core of the Directive is consumer information and the transactional choices consumers make based on the information provided to them through advertisements.

\subsubsection{Degree of Harmonisation}

The Directive is a maximum harmonisation tool, which - at the time it was adopted was unusual, given that the mainstream of consumer legislation in the European Union up until about 2002 aimed for minimum harmonisation. Collins has considered the

\footnotetext{
${ }^{180}$ Ibid., para. 76.

${ }^{181}$ Recital 4 Directive 2005/29/EC

${ }^{182}$ Recital 8 Directive 2005/29/EC
} 
enactment of the UCP Directive to be one of the boldest initiatives throughout the adoption of various, increasingly comprehensive consumer protection measures laying down the foundations for a competitive single market, gradually transforming the legal framework governing the field of business transactions. The Directive creates uniform rules to regulate all marketing practices relating to the induction of consumers to purchase goods and services, controlling unfair marketing practices, misleading advertising, false claims or pressure sales techniques. ${ }^{183}$ It differs from earlier European consumer protection laws firstly in the sense of its comprehensiveness in that it prohibits unfair business practices throughout the EU and, secondly, in its maximum harmonisation nature, thereby creating a uniform set of rules for B2C marketing practices, disallowing national law to prevail in the field of unfair business practices. ${ }^{184}$

The grounds for the adoption of uniform rules, as indicated in Recitals 4 and 5 of the Unfair Commercial Practices Directive, was that legal fragmentation and disparities are not only barriers to trade but also undermine consumer confidence in the internal market. Maximum harmonisation was the result of a political compromise between the Commission and the Member States - and perhaps the greatest source of disagreement between Member States concerned in the course of the debate preceding the adoption of the Directive. The critique of the full harmonisation nature of the proposed instrument came from two directions: on the one hand, certain Member States, such as Denmark and Sweden, were reluctant to reduce the level of consumer protection in their domestic laws, and, on the other hand, some Member States were generally suspicious of the rigidity of the codified laws, particularly when their transnational operation effectively hinders rapid reform. ${ }^{185}$ On the other hand, the Commission pressed hard for full harmonisation against minimum harmonisation, potentially combined with the "country of origin" principle, clearly prioritising the competitiveness of the internal market over high levels of consumer protection in some Member States or reserving room for national innovation. ${ }^{186}$ As a result, there are/were certain reservations inserted in the body of the Directive concerning the level of harmonisation.

Thus, the maximum harmonisation character of the Directive is limited in two ways. Firstly, under Article 3(9), in relation to financial services and immovable property,

\footnotetext{
${ }^{183}$ Collins, H., 'Harmonisation by Example: European Laws against Unfair Commercial Practices', 73 Modern Law Review Nr. 1, (2010), p. 89-118., p. 89.

${ }^{184}$ Ibid., p. 90.

${ }^{185}$ Wilhelmsson, T., 'Private Law in the EU: Harmonised or Fragmented Europeanisation?' 10 European Review of Private Law 77 (2002) as cited by Collins, H., 'Harmonisation by Example: European Laws against Unfair Commercial Practices’, 73 Modern Law Review Nr. 1, (2010), p. 89-118., p. 95.

${ }^{186}$ Collins, H., 'Harmonisation by Example: European Laws against Unfair Commercial Practices', 73 Modern Law Review Nr. 1, (2010), p. 89-118., p. 95.
} 
Member States may impose requirements which are more restrictive or prescriptive than the Directive in the field which it approximates. Secondly, a temporary derogation applied to national provisions which implement directives containing minimum harmonisation clauses. Article 3(5) allowed a period of six years until 12 June 2013, during which Member States were able to continue to apply national provisions which were more restrictive or prescriptive than the Directive itself.

Effects of the Directive's full harmonisation nature have been described and confirmed in the CJEU ruling in the Total Belgium ${ }^{187}$ case. In the course of examining the compatibility of a Belgian law instrument (Law of 14 July 1991 on commercial practices, consumer information and consumer protection, Belgisch Staatsblad of 29 August 1991) with European law, the Court held that

'the Directive fully harmonises those rules at the Community level. Accordingly, [...] Member States may not adopt stricter rules than those provided for in the Directive, even in order to achieve a higher level of consumer protection'. ${ }^{188}$

Interestingly, the maximum harmonisation approach of the UCPD is combined with the "internal market clause" as enshrined in Article 4 of the Directive. Also known as the "country of origin principle", under Article 4 of the UCPD, where an action or service is performed in one country but received by another, the applicable law is the law of the country where the action or service is performed. ${ }^{189}$

\subsubsection{Scope}

The Directive applies to business-to-consumer relations, but does not apply to businessto-business contracts, the latter being governed by the Misleading and Comparative Advertising Directive.

The scope of the Directive was also a debated issue in the sense that many Member State rules do not distinguish between unfair practices directed at consumers and those targeting competitors. In fact, unfair commercial practices such as misleading advertising, for example, are detrimental for both consumers as well as for competing businesses alike. While the Treaty basis -the internal market provision of Article 95 EC (Art. 114 TFEU) to achieve full harmonisation- would have allowed the scope of application to

\footnotetext{
${ }^{187}$ Case C-261/07 and C-299/07 VTB-VAB NV v Total Belgium NV and Galatea BVBA v Sanoma Magazines Belgium NV [2009] ECR-2949

${ }^{188}$ Case C-261/07 and C-299/07 VTB-VAB NV v Total Belgium NV and Galatea BVBA v Sanoma Magazines Belgium NV [2009] ECR-2949

${ }^{189}$ It is noteworthy that the combination of maximum harmonisation and the internal market clause is mutually exclusive, and leads to conflicts of interpretation.
} 
cover competition in relation to both consumers and businesses, the Directive was eventually confined to $\mathrm{B} 2 \mathrm{C}$ relations, probably due to its political origins within the Commission. ${ }^{190}$

Under the UCPD, "consumer" is defined as any natural person who, in commercial practices covered by the Directive, is acting for purposes which are outside his trade, business, craft or profession ${ }^{191}$ (the concept of "consumer" under European law was explained in more detail in sub-section 2.2.2.3.) whereas "trader" means any natural or legal person who, in commercial practices covered by the Directive, is acting for purposes relating to his trade, business, craft or profession and anyone acting in the name of or on behalf of a trader. ${ }^{192}$

The factual scope of application concerns "commercial practices" that (in B2C relations) is defined as any act, omission, course of conduct or representation, commercial communication including advertising and marketing, by a trader, directly connected with the promotion, sale or supply of a product to consumers. ${ }^{193}$ The Directive governs $\mathrm{B} 2 \mathrm{C}$ commercial practices before, during and after a commercial transaction in relation to a product. ${ }^{194}$

\subsubsection{Professional Diligence and the "Average Consumer" Test}

The general legal framework is defined by the comprehensive general clause prohibiting unfair commercial practices. ${ }^{195}$ Under Article 5, a commercial practice is unfair if it is contrary to the requirements of professional diligence and it materially distorts the economic behaviour with regards to the product of the average consumer whom it reaches or to whom it is addressed, or of the average member of the group when a commercial practice is directed to a particular group of consumers.

"Professional diligence" under Article 2 lit. h) means the standard of special skill and care which a trader may reasonably be expected to exercise towards consumers, commensurate with honest market practice and/or the general principle of good faith in the trader's field of activity. This specific term proved rather vague and problematic in practice as the clause is not only too wide and general, but it can also be subject to diverging interpretation in the various legal cultures and/or markets.

\footnotetext{
${ }^{190}$ Collins, H., 'Harmonisation by Example: European Laws against Unfair Commercial Practices', 73 Modern Law Review Nr. 1, (2010), p. 89-118., p. 94.

${ }^{191}$ Article 2 lit. a) Unfair Commercial Practices Directive

${ }^{192}$ Article 2 lit. b) Unfair Commercial Practices Directive

${ }^{193}$ Article 2 lit. d) Unfair Commercial Practices Directive

${ }^{194}$ Article 3(1) Directive 2005/29/EC

195 Micklitz, H-W., Reich, N., Rott,P., Understanding EU Consumer Law (Intersentia, Antwerp - Oxford Portland, 2009), p. 81.
} 
"Material distortion" of the average consumer's behaviour - another ambiguous term - is to be understood as using a commercial practice to appreciably impair the consumer's ability to make an informed decision, thereby causing the consumer to take a transactional decision that he would not have taken otherwise. ${ }^{196}$ In the opinion of Micklitz, Reich and Rott, ${ }^{197}$ the above definition -and in particular, the word "to" as meaning causation- can be understood as requiring intentional conduct on the trader's side for the commercial practice to be qualified as misleading. However, the authors say that the systematic reading of the definitions and the formally limited significance of the definition of the term "transactional decision" point towards a more objective liability of the trader whereby intention or bad will are not required. ${ }^{198}$ Under Article 5(2) lit. b), a commercial practice is unfair if it materially distorts or is likely to materially distort the economic behaviour' of the consumer - it therefore suffices if the commercial practice is prone to distort the consumer's economic behaviour - the actual distortion is not a requirement.

The "average consumer" is the benchmark of unfairness in the Directive - and is defined as a person 'who is reasonably well informed and reasonably observant and circumspect, taking into account social, cultural and linguistic factors,' as interpreted by the Court of Justice. ${ }^{199}$ The average consumer test, under Recital 18, is not a statistical test; and it is up to national courts and authorities to exercise their own faculty of judgment, having regard to the case law of the Court of Justice to determine the typical reaction of the average consumer. Applied in the general clauses, this concept of the "average consumer" was one of the most controversial issues - while, in the course of the interpretation of previous Directives, the Court of Justice did favour this concept of the "average consumer" who is reasonably well informed, reasonably observant and circumspect, though taking into account social, cultural and linguistic factors, concerns were raised by critics in that this approach would not offer sufficient protection to vulnerable consumers against unfair commercial practices. Adopting the Parliament's amendments, the Directive modified the standard of the average consumer in two aspects. Firstly, where the commercial practice is directed to a particular group, the concept of an average consumer should be read as the average member of that particular group, according to Article 5(2) lit. b) of the UCPD. Secondly, under Article 5(3), where a clearly identifiable group is particularly vulnerable to a commercial practice by reason of infirmity, age or credulity, and where the practice is likely to distort only the behaviour

\footnotetext{
${ }^{196}$ Article 2 lit. e) Directive 2005/29/EC

${ }^{197}$ Micklitz, H-W., Reich, N., Rott, P., Understanding EU Consumer Law, p. 86.

${ }^{198}$ Ibid., p. 86.

${ }^{199}$ Recital 18 Directive 2005/29/EC
} 
of that group, the reference to the average consumer should be understood as referring to the average of that group. ${ }^{200}$

The Directive also contains provisions aimed at preventing the exploitation of consumers whose characteristics make them particularly vulnerable to unfair commercial practices. Recital 18 brings the example of children as particularly vulnerable, but it is probable that the Community legislator also intended to give special protection to elderly people. In practice, it may not always be easy to determine which advertisements and/or commercial activities are directed at "average consumers" and which target "vulnerable consumers", however. Particularly, the concept of vulnerable consumers bears relevance for the direct selling industry in the sense that elderly consumers (deemed to fall under the category of "vulnerable consumers") are frequently targeted by distributors as those who are more prone to making purchases in their homes and are also more susceptible to pressure sales techniques.

\subsubsection{Misleading Practices}

Misleading commercial practices, as defined by Article 6 and 7 of the Directive are divided into misleading advertising activities and misleading omissions.

A commercial practice shall be regarded as misleading if it contains false information and is therefore untruthful or in any way, including overall presentation, deceives or is likely to deceive the average consumer, even if the information is factually correct, in relation to one or more of the following elements, and in either case causes or is likely to cause him to take a transactional decision that he would not have taken otherwise. ${ }^{201}$ Under Article 7, a commercial practice shall also be regarded as misleading if, in its factual context, taking account of all its features and circumstances, it causes or is likely to cause the average consumer to take a transactional decision that he would not have taken otherwise, provided that the commercial practice involves a set of criteria described in the Directive, such as any marketing of a product that creates confusion between products or trademarks etc. ${ }^{202}$ The proportionality principle requires that the consequences of such unfair commercial practices be material but at the same time recognises that in some cases the impact on consumers may be negligible. ${ }^{203}$

\footnotetext{
${ }^{200}$ Collins, H., 'Harmonisation by Example: European Laws against Unfair Commercial Practices', 73 Modern Law Review Nr. 1, (2010), p. 89-118., p. 99-100.

${ }^{201}$ Article 6 Directive 2005/29/EC

${ }^{202}$ Article 6(2) lit. a) Directive 2005/29/EC

${ }^{203}$ Recital 6 Directive 2005/29/EC
} 
The autonomous concept of misleading advertising has been further developed by the European Court of Justice. In its rulings in Yves Rocher, ${ }^{204}$ Mars $^{205}$ and Lifting ${ }^{206}$ the CJEU has established the objective/concrete criterion of misleading advertising - objective as to the function of the advertising and concrete in that the consumer has in concreto been misled. ${ }^{207}$ As regards the abstractness of the risk, it is highly debated whether the CJEU in Nissan ${ }^{208}$ has accepted even the abstract risk of being misled. ${ }^{209}$

In Gut-Springenheide ${ }^{210}$ however, the Court emphasized that the mere suitability of being misleading was of relevance. In the event that the necessary facts for the CJEU to decide on the misleading effect of the advertisement are missing, the CJEU leaves it up to the national courts to decide whether a certain advertisement is misleading. This interplay between the CJEU and national courts has been confirmed in Sektkellerei Kessler ${ }^{211}$ and Lifting. ${ }^{212}$ Consequently, an advertising or commercial practice is misleading in cases when it actually misleads consumers but also when the Court of Justice normatively establishes general criteria for an advertisement to be considered misleading, but leaving it up to national courts to provide evidence. ${ }^{213}$ Under EU law, the abstract risk does not suffice for a commercial practice to be deemed misleading - it must entail a concrete danger for consumers to make a transactional decision that will be detrimental to them and that they otherwise would not have taken. ${ }^{214}$

Misleading advertising concerning the direct selling sales channel typically manifests in the form of income and earnings misrepresentations (made towards consumers and traders alike). Income claims are not forbidden under EU law per se, but can fall under the scope of misleading advertising if it is not based on clear and conspicuous income disclosures provided by the direct selling company. In an effort to recruit a higher number of distributors and thus receive more commissions from the direct selling company, distributors may feel tempted to make ungrounded, false income claims. At the same time however, direct selling companies generally do not have any legal obligations to provide data on distributors' earnings to national tax authorities, which does create a

\footnotetext{
${ }^{204}$ Case C-126/91 Schutzverband gegen Unwesen in der Wirtschaft v Yves Rocher [1993] ECR I-2361

${ }^{205}$ Case C-470-93 Verein gegen Unwesen in Handel und Gewerbe Köln eV v.Mars [1995] ECR I-1923

${ }^{206}$ Case C-220/98 Lifting - Creme [2000] ECR I-117

${ }^{207}$ Micklitz, H-W., Reich, N., Rott, P., Understanding EU Consumer Law, p. 92.

${ }^{208}$ Case C- 373/90 Criminal Proceedings against Nissan [1992] ECR I-131

${ }^{209}$ Micklitz, H-W., Reich, N., Rott, P., Understanding EU Consumer Law, p. 92.

${ }^{210}$ Case C-210/96 Gut Springenheide v Oberkreisdirektor Steinfurt [1998], ECR I-1923

${ }^{211}$ Case C-303/97 Verbraucherschutzverein v Sektkellerei Kessler [1999] ECR I-513

${ }^{212}$ Case C-220/98, Lifting - Creme [2000] ECR I-117

${ }^{213}$ Micklitz, H-W., Reich, N., Rott, P., Understanding EU Consumer Law, p. 93-94.

${ }^{214}$ Ibid., p. 94.
} 
difficulty when assessing the truthfulness of claims for both recruits and enforcement bodies.

In a landmark case in the UK in 2007 in which the then-Department of Trade Industry petitioned the Companies Court for the winding up of Amway UK Limited ${ }^{215}$, the issue of earnings misrepresentations arose in the context of direct selling. Following an investigation into Amway's affairs, the Department for Trade and Industry petitioned for the winding up of Amway on public interest grounds on the basis that Amway's business was inherently objectionable and/or an unlawful lottery and/or an unlawful trading scheme. The original petition was dismissed by the High Court based, in part, on the Court's acceptance of the steps Amway had taken to change its business model and the undertakings it gave concerning its future conduct. Although the Department of Trade appealed, the Court of Appeal upheld the High Court judgment. While the Judge dispersed the complaints that Amway was an unlawful lottery and/or an unlawful trading scheme, Amway was found responsible because of misstatements and misrepresentations made by its distributors in the course of the recruitment process. The Judge decided however that it would not be equitable to wind up Amway as it had already revised its business model and because based on the evidence, there were over 7000 people who wished to continue to be Amway distributors. The undertakings were to prohibit the production, sale or promotion of business support materials not authorised and distributed by Amway; not to introduce a registration or renewal fee; not to recruit new distributors until Amway had published earnings data in accordance with a stated income disclosure policy and that all new distributors would be required to undertake an orientation program operated by Amway to reduce the risk that they were joining on the basis or any misrepresentation or misunderstanding as to how the business works, or had not been given the requisite warnings. ${ }^{216}$

Following the detailed assessment of misleading advertising, and its typical form in direct selling, earning misrepresentations, the second form of misleading practices, namely misleading omissions, is to be looked into. Rules concerning misleading omissions, as provided for by Article 7 of the Directive, are intended to protect consumers through ensuring they are given all the data they need to make an informed decision on the commercial transactions. Misleading omissions may occur through the omission of material information ${ }^{217}$ or the vague, unintelligible or ambiguous way of providing ma-

\footnotetext{
${ }^{215}$ BERR vs Amway UK

216 Lawrence Graham LLP: 'Amway defeats legal challenge in the UK', 16 May 2008, available at http://www.docstoc.com/docs/87964902/Sales-Management-Practice-of-Amway (last visited 20 June 2014)

${ }^{217}$ Article 7(1) Directive 2005/29/EC
} 
terial information. ${ }^{218}$ Material information is understood as the main characteristics of a product, the geographical address and the identity of the trader, the price inclusive of taxes, method of payment, delivery and the information on the right of cancellation or withdrawal where such a right exists. ${ }^{219}$

\subsubsection{Aggressive Practices and Pressure Sales}

A somewhat underdeveloped concept in European law, ${ }^{220}$ but a key regulatory aspect when dealing with direct selling methods, or rather, the abuse thereof, the notion of aggressive practices is difficult to define precisely. Under Article 8, aggressive practices are practices in their factual context, taking account of all their features and circumstances, by harassment, coercion, including the use of physical force, or undue influence, that significantly impair or are likely to significantly impair the average consumer's freedom of choice or conduct with regard to the product and thereby cause him or is likely to cause him to take a transactional decision that he would not have taken otherwise. $^{221}$

Aggressive practices include harassment, coercion and undue influence, but the threshold intensity that needs to be reached as regards these three sub-categories is lacking in the Directive. ${ }^{222}$ Equally unclear is how the boundaries between harassment, coercion and undue influence are to be set, but, as Koehler and Lettl suggest, a distinction between these categories is neither possible, nor necessary. ${ }^{223}$

The definition of harassment and coercion are lacking in the Directive as such, and it is therefore uncertain which commercial practices are actionable under these categories. The materiality test in the UCPD and the de minimis rule of tort law rule out trifle claims, yet, Article 8 remains an open-ended invitation to various claims. ${ }^{224}$ It is also noteworthy that the interests of traders are not protected under these provisions alt-

\footnotetext{
${ }^{218}$ Article 7(2) Directive 2005/29/EC

${ }^{219}$ Article 7(4) Directive 2005/29/EC

${ }^{220}$ Howells G., Micklitz H-W., Wilhelmsson T., European Fair Trading Law: The Unfair Commercial Practices Directive, p. 170.

${ }^{221}$ Article 8 Directive 2005/29/EC

${ }^{222}$ Howells G., Micklitz H-W., Wilhelmsson T., European Fair Trading Law, The Unfair Commercial Practices Directive, p. 173.

${ }^{223}$ Kohler-Lettl, 'Das geltende europaische Lauterkeitsrecht, der Vorschlag fuer eine EG-Richtlinie ueber unlautere Geschaeftpraktiken und die UWG-Reform 2003' Wettbewerb in Recht und Praxis (2003), p.1019. as cited in Howells G., Micklitz H-W., Wilhelmsson T., European Fair Trading Law, The Unfair Commercial Practices Directive, p. 173.

${ }^{224}$ Osuji, O. K., 'Business-to-consumer Harassment, Unfair Commercial Practices Directive and the UK - A Distorted Picture of Uniform Harmonisation?' 34 Journal of Consumer Policy, Number 4, Springer Publications (2011), p. 437-453, p. 444.
} 
hough this is one of the aims of the UCPD - as enshrined in Recital $8 .^{225}$ It is Article 9 that provides some guidance for the determination whether a commercial practice uses harassment, coercion, including the use of physical force, or undue influence. In the interpretation of these practices, account shall be taken of the timing, location, nature or persistence of the commercial practice; the use of threatening or abusive language or behaviour; the exploitation by the trader of any specific misfortune or circumstance of such gravity as to impair the consumer's judgment, of which the trader is aware, to influence the consumer's decision with regard to the product; any onerous or disproportionate non-contractual barriers imposed by the trader where a consumer wishes to exercise rights under the contract, including rights to terminate a contract or to switch to another product or another trader; any threat to take any action that cannot legally be taken.

The use of physical force, as a means of coercion, in order to "encourage" consumers to make a purchase is explicitly mentioned in the Directive. Howells argues that it is only due to bad draughtsmanship that the use of physical force is mentioned as a means of coercion, and not as a possible feature of all three categories of aggressive practices: harassment, coercion and undue influence. ${ }^{226}$

"Undue influence" means exploiting a position of power in relation to the consumer so as to apply pressure, even without using or threatening to use physical force, in a way which significantly limits the consumer's ability to make an informed decision.

An aspect of undue influence in relation to direct selling is featured in the Consumer Rights Directive which defines contexts of off-premises contracts where the consumer may be under psychological pressure or may be confronted with an element of surprise $^{227}$ and provides for the right of withdrawal because of the said potential psychological pressure and/or surprise element. ${ }^{228}$

Besides the potential pressure to purchase products, another typical complaint against the direct selling method, and, in particular, multi-level sales is that distributors tend to take advantage of their social networks and friendships in order to build their businesses, i.e. to sell the company's products and to recruit more sales-force. This is an area where it is again difficult to distinguish undue influence from assertive marketing.

The definition of aggressive practices again refers to the average consumer test and prescribes the significant impairment or the probability of significant impairment of the

\footnotetext{
${ }^{225}$ Ibid., p. 444.

${ }^{226}$ Howells G., Micklitz H-W., Wilhelmsson T., European Fair Trading Law: The Unfair Commercial Practices Directive, p. 187.

${ }^{227}$ Recital 21 2011/83/EU

${ }^{228}$ Recital 37 2011/83/EU
} 
consumer's transactional choice. Aggressive practices are to be assessed in their factual contexts under Article 8, which means that abstract rules or blanket prohibitions on aggressive practices are not prevented, but that the concrete form of the practice is to be assessed. $^{229}$

What must be born in mind, however, is that the notion of "aggression" contains a great deal of culture-specific component, which is realized in significant perception differences as regards aggression and the intrusive effects of commercial practices, argues Micklitz. ${ }^{230}$ Different value judgments are reflected in the treatment of direct selling in various Member States or cultural regions: Scandinavian nations tend to have strong reservations against direct selling, Germany bans commercial selling at public spaces, whereas Austria requires that the respective enforcement authority be notified about the organisation of party plan events six weeks in advance. Thus, the realisation that a commercial practice is aggressive to some extent remains the result of a subjective judgment of the consumer. ${ }^{231}$

Items 24-31 of Annex I are deemed aggressive commercial practices and are outlawed in all circumstances. Some of these practices - when the consumer may not leave the premises until a contract is formed ${ }^{232}$ or if a consumer is explicitly informed that if he does not buy a product or service, the trader's job or livelihood will be in jeopardy ${ }^{233}$ - can be directly linked to direct selling and are effective tools in protecting consumers against rogue traders abusing the direct selling channel and selling methods.

\subsubsection{Pyramid Schemes}

The Blacklist - Annex I - entails commercial practices that are banned outright as they are deemed unfair in all circumstances. In the course of the drafting, the Commission refused to discuss the maximum harmonisation principle of the Directive, therefore the consumer lobby was advised to focus on Annex I. ${ }^{234}$ For the direct selling industry, the most relevant of the 31 commercial practices on the Blacklist is item 14 on pyramid schemes, given the role the definition plays in distinguishing fraudulent schemes from legitimate MLMs.

\footnotetext{
${ }^{229}$ Howells G., Micklitz H-W., Wilhelmsson T., European Fair Trading Law, The Unfair Commercial Practices Directive, p. 178.

${ }^{230}$ Micklitz, H-W., 'Aggressive Werbung' in Heermann, P. W. and Hirsch, G. (eds.), Munchener Kommentar zum Lauterkeitsrecht (C.H. Beck, Munchen, 2006), p. 904-984., p. 904-916.

${ }^{231}$ Micklitz, H-W., Reich, N., Rott, P., Understanding EU Consumer Law, p. 108.

${ }^{232}$ Item 24, Annex I Directive 2005/29/EC

${ }^{233}$ Item 30, Annex I Directive 2005/29/EC

${ }^{234}$ Howells G., Micklitz H-W., Wilhelmsson T., European Fair Trading Law: The Unfair Commercial Practices Directive, p. 22.
} 
The exact wording of item 14 - the definition of pyramid schemes- is 'where a consumer gives consideration for the opportunity to receive compensation that is derived primarily from the introduction of other consumers into the scheme rather than from the sale or consumption of products.' Under the current European legislation, pyramid schemes are per definition based on B2C transactions (as we will see in the section to follow, the MCAD does not contain a pyramid scheme definition that would outlaw B2B pyramid promotional schemes); and the establishment, operation or the promotion of pyramid schemes is considered an unfair commercial practice under all circumstances.

Because of the generic nature of the definition, certain hallmarks of true pyramid promotional schemes such as misleading earnings claims (when consumers or direct sellers [who are per definition traders] are lured into participation in the scheme by making unsubstantiated earnings claims), large entry fees (the notion of pressuring distributors into purchasing excessive inventory or the increase of investment), internal consumption (when the scheme is not predominantly focused on sales outside the system) are missing from this definition.

As a field of strategic importance, the pyramid scheme regulation in Europe will be analysed in considerably more detail in chapter IV.

\subsubsection{Self-Regulation}

Self-regulation is provided for by Article 10 of the Unfair Commercial Practices Directive. Self-regulation succeeds through the establishment of a code of conduct and the adherence thereto. Codes of conduct can also be viewed as yardsticks of professional diligence referred to in the definition of misleading commercial practices of Article 5 (2) lit. a). High standards of voluntary codes which enjoy wide support and compliance on the industry's side 'may be a useful term of reference for national authorities and courts in assessing whether, in a concrete case, a commercial practice is unfair'. ${ }^{235}$

The aim of codes of conduct is to enhance the level of consumer protection, encourage fair trading and to thereby stimulate the enforcement of the Directive. The Directive does not lay down criteria which the codes of conduct have to abide by in order to be fair, nor are codes of conduct deemed fair that have been compiled in consultation with consumer organisations or authorities.

The issue of compliance with various codes is a precarious one: the trader does not necessarily have to be a signatory to any code of conduct in order to fulfil requirements

235 European Commission, Commission Staff Working Document, Guidance on the implementation/application of the Directive 2005/29/EC on unfair commercial practices, SEC (2009) 1666, Brussels, 3 December 2009, p. 20. 
of "professional diligence". In the event that the trader does not comply with a code that the trader has signed, the trader's conduct is deemed a misleading practice under Article 6(2) lit. b). Furthermore, Annex I (the Blacklist) of the Directive forbids false claims about being signatories to codes and trust marks: ${ }^{236}$ these practices are deemed unfair in all circumstances.

Although the Directive provides no privileges for signatories of codes of conduct, it does take some steps towards encouraging self-regulation. Firstly, in the framework of enforcement, the Directive does allow Member States to enable the courts or administrative authorities to require prior recourse to other established means of dealing with complaints, including the codes of conduct, in addition to taking legal action and/or bringing unfair commercial practices before competent administrative authorities. ${ }^{237}$ Secondly, the Directive prescribes Member States - where appropriate - to encourage traders and code owners to inform consumers of their codes of conduct. ${ }^{238}$

A later chapter of industry self-regulation (chapter V) will describe the efforts the direct selling industry makes both at a global, as well as at European level to set common standards and a normative framework establishing specific rules of ethical trading within the sector.

\subsubsection{Marketing Law in Business-to-Business Relations: the Misleading and Comparative Advertising Directive}

An efficient marketing tool, comparative advertising increases product market and price transparency and provides the consumer with useful information. While US companies have been using this marketing strategy for decades, the European Union has appeared to be more cautious. ${ }^{239}$ In the European Union, the main piece of legislation on marketing practices for a long time has been Directive 84/450/EEC on misleading advertising. This Directive was later modified in 1997 by $97 / 55 / E C$ on comparative advertising.

\footnotetext{
${ }^{236}$ Annex I 1-3 specifies the false claims about being signatories to codes and trust marks that are forbidden in all circumstances:

1. Claiming to be a signatory to a code of conduct when the trader is not.

2. Displaying a trust mark, quality mark or equivalent without having obtained the necessary authorization.

3. Claiming that a code of conduct has an endorsement from a public or other body which it does not have.

${ }^{237}$ Article 11(1) Directive 2005/29/EC

${ }^{238}$ Article 17 Directive 2005/29/EC

${ }^{239}$ Thress, K. C., 'Comparative advertising in the European Union', Gibbons Law P.C. (18 November 2011), http://www.gibbonslaw.com/news_publications/articles.php?action=display_publication\&publication_id=356 9 (last visited on 17 September 2014)
} 
Directive 97/55/EC contained a coherent set of rules on comparative advertising applying to both $\mathrm{B} 2 \mathrm{~B}$ and $\mathrm{B} 2 \mathrm{C}$ relations. ${ }^{240}$ It was at the entry into force of the Unfair Commercial Practices Directive that the scope of the Comparative Advertising Directive was limited to B2B relations concerning misleading advertising - as the Unfair Commercial Practices Directive became the piece of legislation that governs B2C marketing relations. When the Unfair Commercial Practices Directive entered into force on 12 June 2005, the Directive on misleading advertising was amended. The scope of the Directive on misleading advertising was thus limited to $\mathrm{B} 2 \mathrm{~B}$ relations, in order to protect traders against misleading advertising and the unfair consequences thereof. However, the Directive on misleading advertising was soon replaced by its codified version, Directive 2006/114/EC on misleading and comparative advertising. ${ }^{241}$

\subsubsection{Legal Basis and Scope}

Directive 2006/114/EC is aimed at protecting traders and consumers against misleading advertising, which is equivalent to unfair commercial practice. The legal basis of this instrument is again Article 95 of the Treaty establishing the European Economic Community (now Article 114 TFEU) on the establishment of the internal market. The objective of the Directive, as provided for in Article 1, is to protect traders and consumers against misleading advertising and to lay down criteria under which comparative advertising is permitted. Provisions of the 2006/114/EC Directive on misleading and comparative advertising also apply in the context of advertising directed at consumers ${ }^{242}$ whereas the scope of the provisions on misleading advertising are restricted to $\mathrm{B} 2 \mathrm{~B}$ relations (misleading advertising in B2C relations is governed by the Unfair Commercial Practices Directive).

\subsubsection{Degree of Harmonisation}

The 2006/114/EC Directive on misleading and comparative advertising is a minimum harmonisation directive, which in theory means that Member States may adopt more stringent protective measures in their national legislations. This standpoint however is not an undisputed one. Trzaskowski claims that the minimum harmonisation character of the directive on misleading advertising takes effect only in cases where non-consumer interests are at stake, as consumer interests are covered by the Unfair Commercial Prac-

\footnotetext{
${ }^{240}$ Ibid.

${ }^{241}$ Ibid.

242 DG Justice's website on Misleading Advertising, available at http://ec.europa.eu/justice/consumermarketing/unfair-trade/false-advertising/index_en.htm (last visited 17 September 2014)
} 
tices Directive. ${ }^{243}$ This line of argumentation appears to have been supported by the CJEU in Mediaprint ${ }^{244}$ in so far as it stated that

'As is evident from recital 6 in the preamble to the Directive, only national legislation relating to unfair commercial practices which harm "only" competitors' economic interests or which relate to a transaction between traders is thus excluded from that scope. ${ }^{245}$

\subsubsection{Misleading and Comparative Advertising}

Advertising is defined as the making of a representation in any form in connection with a trade, business, craft or profession in order to promote the supply of goods or services, including immovable property, rights and obligations under Article 2(a).

Misleading advertising, as defined by Article 2, means any advertising which in any way, including its presentation, deceives or is likely to deceive the persons to whom it is addressed or whom it reaches or which, by reason of its deceptive nature, is likely to affect their economic behaviour or which, for those reasons, injures or is likely to injure a competitor.

When determining whether an advertising is misleading, Article 3 prescribes that all the features of the said promotion are to be taken into account, in particular the characteristics of goods or services, the way the price or the manner is calculated, the conditions under which the goods or services are provided and the nature, attributes and rights of the advertiser.

Prohibition of misleading advertising in B2B transactions bears crucial relevance for direct selling in two ways: firstly, direct selling companies have an obligation to not misrepresent the actual or potential earnings of their direct sellers and should not for that matter be based on isolated cases of success, but are to be based on transparent data and documentation. Secondly, sales aids and other commercial material that distributors compile and sell to other distributors (most likely to their downline, i.e. to distributors they sponsor and train) must be consistent with marketing law.

A landmark case concerning a direct selling company's misleading publications of income and earnings potentials was that of Amway in the US in the late 1970s. Amway was investigated in the US based on a lawsuit filed by the Federal Trade Commission

\footnotetext{
${ }^{243}$ Letto-Vanamo, P; Smits, J. (eds.): Coherence and Fragmentation in European Private Law (Sellier European Law Publishers, Munchen, 2012), p. 93.

${ }^{244}$ Case C-540/08, Mediaprint Zeitungs- und Zeitschriftenverlag v. Osterreich Zeitschriftenverlag [2010] ECR I0000

${ }^{245} \mathrm{Ibid}$., para. 21.
} 
(FTC) against the corporation on the grounds of earnings misrepresentations, amongst other reasons. ${ }^{246}$ The FTC alleged that Amway falsely stated that it was 'easy to recruit other distributors' and that 'distributors will receive substantial earnings. ${ }^{247}$ Furthermore, the FTC complaint stated that Amway misrepresented the profitability of distributorship by failing to disclose that there was substantial turnover amongst its distributors, and that substantial expenses incurred in the business of being an Amway distributor. ${ }^{248}$ Although it was concluded that Amway Corporation is not a pyramid scheme, the administrative law judge found, and the FTC opinion agreed, that Amway engaged in misleading sales and earnings claims. ${ }^{249}$ In the Final Order, issued on May 8, 1979, Amway and its representatives were ordered to cease misrepresenting profits, earnings or sales; and stop implying other than average results, unless the average results or the percentage of distributors actually reaching those figures is also conspicuously disclosed. ${ }^{250}$ As was the case In the Matter of Amway Corporation, Inc., et al., the FTC considers every earnings claim a "deceptive trade practice" unless it is accompanied by a simultaneous disclosure of distributors' average earnings and the percentage of distributors who achieve various earning levels. ${ }^{251}$

Although the court case and investigation took place in the United States, it has provided a compass for the entire industry in a number of ways. First of all, because the MLM marketing method originates from, and is oriented towards, US practices. The American legislature and judiciary was often the first to face legal issues arising from the abuse of the sales channel and has therefore impacted other regulatory systems by serving as an example. For instance, as chapter IV will describe in detail, the current European pyramid scheme definition has largely been based on US federal law instead of EU Member State regulations. Moreover, the groundbreaking "Amway case" has had a very strong impact on the industry's private regulatory system in terms of the permissibility of earnings claims made by direct selling corporations towards distributors and pyramid scheme safeguards.

A key concept, also for the fair competition between direct selling corporations, comparative advertising is the second terrain regulated by the MCAD. The legal defini-

\footnotetext{
${ }^{246}$ In the Matter of Amway Corporation, Inc., et al. 93 F.T.C. 618 (1979)

${ }^{247}$ FTC Complaint In the Matter of Amway Corporation, Inc., para. 22-23. as cited in Grimes, K., D., MLMLaw.com, 'Income and Earnings Representations 1996-2003' on p. 20., http://www.mlmlaw.com/library/ guides/IncomeClaims.pdf (last visited 17 September 2014)

${ }^{248}$ Ibid., p. 20.

24993 F.T.C. 618 : Opinion, p. 735.

25093 F.T.C. 618: Final Order, p. 736-738.

${ }^{251}$ Babener, J., JDSupra Business Advisor, 'Direct Sales - An Overview - The Legal Environment', 2010, p. 18., http://www.jdsupra.com/legalnews/direct-sales-an-overview-the-legal-env-95441/ (last visited 17 September 2014)
} 
tion of "comparative advertising" is enshrined in Article 2(c) and means any advertising which explicitly or by implication identifies a competitor or goods or services offered by a competitor. Comparative advertising is therefore already present when a competitor is made visible in a manner that makes it identifiable. ${ }^{252}$ This broad definition of Article 2 of the MCAD and Article 6 of Directive 2005/29/EC is not restricted ${ }^{253}$ and the CJEU has refused to narrow down the definition in Toshiba ${ }^{254}$ and Pippig ${ }^{255}$ in order to limit the Directive's scope of application. In both cases, the producers could not be directly identified and therefore additional efforts were necessary to determine the producers of the comparative products. A broad definition allows the coverage of various means of comparative advertising, including cases where a declaration - even if only indirectly refers to a competitor or the goods or services he offers. ${ }^{256}$

A major shortcoming is that the Directive contains no definition of the average based yardstick. The same advertisement (or any other marketing tool) can be subject to two different sets of legislation, depending on who is likely to be misled by it. If the advertisement regards consumers' interests and therefore consumer protection is involved, the national laws implementing the Unfair Commercial Practices Directive apply, but if competitors are concerned, the national laws implementing the Misleading and Comparative Advertisement Directive govern the situation, even though the consumer collective is the addressee of the marketing tool. ${ }^{257}$

Article 4 contains a "legality checklist" 258 prescribing the conditions that need to be met for comparative advertising to be permitted. By implication, comparative advertising is permissible only if the advertisement contains a comparison in the form of an evaluative or equivalence assertion. ${ }^{259}$ Under Article 4, comparative advertising shall, as far as the comparison is concerned, be permitted when the following conditions are met: - Under Article 4 (1) lit. a), comparative advertising may not be misleading within the meaning of Articles 2(b), 3 and 8(1) of the Directive or Articles 6 and 7 of Directive 2005/29/EC on Unfair Commercial Practices Directive. The former Directive applies

\footnotetext{
${ }^{252}$ Thress, K. C., Gibbons Law P.C, 'Comparative advertising in the European Union', November 18, 2011, http://www.gibbonslaw.com/news_publications/articles.php?action=display_publication\&publication_id=356 9 (last visited on 17 September 2014) 
when the addressees of the misleading advertising are traders, whereas the latter is applicable in cases when the misleading advertising targets consumers. Should the advertising target both consumers and traders, both directives apply.

- Misleading comparative advertisements compare goods or services meeting the same needs or intended for the same purpose, as prescribed in Article 4 (1) lit. b). This provision requires the functional interchangeability or 'sufficient degree of "interchangeability"' as defined by the CJEU, in other words, the potential to replace the advertised product by a competitor's offer. ${ }^{260}$

- Article 4 (1) lit. c) requires the objective comparison of one or more material, relevant, verifiable and representative features of those goods and services, which may include price. Distinctive features must therefore be compared in an objective manner and thus result in the consequence that advertisements that appeal to the subjective perception and/or sensation of a consumer are prohibited under EU law. ${ }^{261}$

- A further requirement - enshrined in Article 4 lit. d) - is that the comparative advertisement does not discredit or denigrate the trademarks, trade names, other distinguishing marks, goods, services, activities or circumstances of a competitor. In Pippig, ${ }^{262}$ the CJEU held that comparing rival offers, particularly as regards price, is of the very nature of comparative advertising. Therefore, comparing prices cannot in itself entail the discrediting or denigration of a competitor who charges higher prices. ${ }^{263}$ Furthermore, the Court held that, where the comparison does not have the intention or effect of giving rise to such situations of unfair competition, the use of a competitor's brand name is permitted by Community law. ${ }^{264}$ Moreover, concerning the reproduction in the advertising message of the competitor's logo and a picture of its shop front, it is important to note that (...) use of another's trade mark, trade name or other distinguishing marks does not breach that exclusive right in cases where it complies with the conditions laid down by the Directive. ${ }^{265}$

- The subsequent requirement, Article 4 lit. e) prescribes that, for products with designation of origin, comparative advertisement relates in each case to products with the same designation. The aim of this provision is to protect products with designation of origin. In the event that designation of origin is indicated, it may only be compared to products with the same geographical indication of origin. Article 4 lit. f) prohibits com-

\footnotetext{
${ }^{260}$ Case C-381/05 De Landtsheer Emmanuel SA v CPVC and Veuve Clicquot Ponsardin SA [2007] ECR I-3115, para. 44.

${ }^{261}$ Micklitz, H-W., Reich, N., Rott, P., Understanding EU Consumer Law, p. 103.

${ }^{262}$ Case C-44/01, Pippig, para. 80.

${ }^{263}$ Case C-44/01, Pippig, para. 80.

${ }^{264}$ Ibid., para. 49.

${ }^{265}$ Ibid., para. 83 .
} 
parative advertising that takes unfair advantage of the reputation of a trademark, trade name or other distinguishing marks of a competitor or of the designation of origin of competing products. According to the Toshiba judgment, where the Court was asked about the admissibility of a comparison of a generic product and a brand-name product, the Court held that

'the indication of an equipment manufacturer's product numbers alongside a competing supplier's product numbers constitutes a positive statement that the technical features of the two products are equivalent and therefore it constitutes a comparison within the meaning of the Directive. ${ }^{266}$

It is however necessary to determine also whether that indication could cause the public to associate the equipment manufacturer, whose products are those identified, with the competing supplier, in that the public might associate the reputation of that manufacturer's products with the products of the competing supplier. In order to make that determination, the overall presentation of the advertising at issue must be considered. ${ }^{267}$ In $L^{\prime}$ Oreal, ${ }^{268}$ the CJEU ruled that it is not necessary to demonstrate harm to a trade mark in order for there to be an unfair advantage. The advantage is unfair where that party seeks by that use to ride on the coat-tails of the mark with a reputation in order to benefit from the power of attraction, the reputation and the prestige of that mark and to exploit, without paying any financial compensation, the marketing effort expended by the proprietor of the mark in order to create and maintain the mark's image.

- Article 4 lit. g) requires that the advertisement does not present goods or services as imitations or replicas of goods or services bearing a protected trademark or trade name. This rule does not prohibit the promotion of a counterfeit product in such a manner as to mislead the addressees into believing that it has been made by another manufacturer when it is not. The opposite is true: according to this rule it is not tolerable to promote one's own product as a counterfeit of another competitor's product. This assumes that the advertisement itself announces the product as an imitation of a competitor's product whereas it is not necessary to describe the product as an imitation by word. However, the advertising should point out that the product neither belongs to the original brand nor that it was manufactured by the same competitor. Insofar, this rule does not apply when someone else's product is shown in the advertisement as a counterfeit. ${ }^{269}$ As the

\footnotetext{
${ }^{266}$ Case C-112/99 Toshiba v Katun, para. 39.

${ }^{267}$ Ibid., para. 56 - 57.

${ }^{268}$ Case C-487/07 L’Oréal v Bellure [2009] ECR I-05185

${ }^{269}$ Thress, K. C., 'Comparative advertising in the European Union', Gibbons Law P.C. (18 November 2011), http://www.gibbonslaw.com/news_publications/articles.php?action=display_publication\&publication_id=356 9 (last visited on 17 September 2014)
} 
CJEU specified in L'Oreal, ${ }^{270}$ the particular object of this condition is to prohibit an advertiser from stating in comparative advertising that the product or service marketed by him constitutes an imitation or replica of the product or the service covered by the trade mark. ${ }^{271}$ In that regard it is not only advertisements which explicitly evoke the idea of imitation or reproduction which are prohibited, but also those which, having regard to their overall presentation and economic context, are capable of implicitly communicating such an idea to the public at whom they are directed. ${ }^{272}$ It can be concluded that this provision does not apply when another manufacturer's product is promoted in the advertisement as a counterfeit. ${ }^{273}$

- Lastly, Article 4 lit. h) prescribes that the advertisement does not create confusion among traders, between the advertiser and a competitor or between the advertiser's trademarks, trade names, other distinguishing marks, goods or services and those of a competitor. Under this provision, it is not required that the advertisers intentionally mislead addressees of the advertisement into believing that the promoted product has been made by another (or the original) manufacturer. ${ }^{274}$ This rule applies even if the advertiser is not willing to mislead the addressees into believing that the promoted product has been made by another manufacturer. What is more, in L'Oreal the CJEU already indicated that the term "create confusion" has to be read as "create a likelihood of confusion, ${ }^{275}$ an actual confusion therefore is not necessary. The term itself has to be interpreted the way 'that the public might believe that the goods or services in question come from the same undertaking or, as the case may be, from economically-linked undertakings.' ${ }^{276}$

\subsection{Conclusions}

The aim of the present chapter was to present an overview of the key European legal instruments governing the field of direct selling that is essential for understanding the

\footnotetext{
${ }^{270}$ Case C-487/07 L'Oréal v Bellure

${ }^{271}$ Ibid., para. 75 .

${ }^{272}$ Opinion of Advocate General Mengozzi at para. 84 in Case C-487/07 L'Oréal/Bellure

273 Thress, K. C., 'Comparative advertising in the European Union', Gibbons Law P.C. (November 18, 2011), http://www.gibbonslaw.com/news_publications/articles.php?action=display_publication\&publication_id=356 9 (last visited on 17 September 2014)

${ }^{274}$ Ibid.

${ }^{275}$ Case C-533/06 O2 Holdings Ltd v Hutchison 3G UK Ltd [2008] ECR I-4231, para. 49.; Wilhelmsson in Howells, Micklitz, Wilhelmsson (eds.), European Fair Trading Law - The Unfair Commercial Practices Directive, 2006, p. 146.

${ }^{276}$ Case C-533/06 O2 Holdings Ltd v Hutchison $3 G$ UK Ltd., para. 59.
} 
industry's legislative lobbying dossiers. In other words, the aim was to briefly recap the most relevant provisions of European law as an introduction and preparation for the advocacy dossiers that deal with very specific aspects of consumer- and unfair competition law.

Key aspects and the development of European consumer contract law have been indicated through the description of the Doorstep Selling Directive and the Consumer Rights Directive. The paradigmatic change from minimum to maximum harmonisation that took place with the entry into force of the Consumer Rights Directive has gained special attention throughout the analysis, indicating the impact of this transition on both the elements of off-premises consumer contracts (such as the regulation of information requirements, the length of the withdrawal period and the uniform withdrawal form, for example) but also on Member States' -now very limited- freedom to pass diverging legislation concerning this particular field and the abrogation of Member States' earlier entitlement based on the Doorstep Selling Directive to maintain or introduce a total or partial prohibition on the conclusion of direct selling contracts, inasmuch as they consider this to be in the interest of consumers.

In describing the Doorstep Selling Directive and the Consumer Rights Directive, the goal was to prepare the grounds for understanding the case study on the industry's advocacy concerning the Consumer Rights Directive (chapter III). The brief introduction of the Doorstep Selling Directive indicated the starting point from where various lobbying positions were developed and the key legal issues that the industry and consumers faced at the time. The description of relevant aspects of the Consumer Rights Directive has focused on the main areas of interest: the level of harmonisation, trade liberalisation, the scope of application, information obligations or the withdrawal right that have been addressed by the stakeholders in the course of lobbying the dossier, as will be seen in the chapter to follow.

Thereafter, the business-to-consumer as well as the business-to-business aspect of European unfair competition law was introduced through the Unfair Commercial Practices Directive and the Misleading and Comparative Advertising Directive respectively. Again, unfair commercial practices specific to direct selling, such as false earnings claims (in B2C and B2B contexts), aggressive sales methods or the promotion of fraudulent pyramid schemes have been highlighted.

The purpose of the sections describing unfair competition law in brief was manifold. Firstly, the introduction of the UCPD and the MCAD provided a general context for highlighting the main issues of unfair commercial practices specific to direct selling pressure sales techniques, aggressive practices, misleading claims (especially misleading 
earnings claims) and the operation of pyramid promotional schemes- and how the European legislator regulates these issues.

Secondly, the regulation of pyramid promotional schemes was placed in the framework of European fair trading law and it was indicated how this practice is only defined and blacklisted by the Unfair Commercial Practices Directive at the moment but not the Misleading and Comparative Advertising Directive. It was also indicated how, besides a rather generic definition of the pyramid promotional scheme in Item 15 Annex I of the UCPD, some hallmark features of pyramid schemes -such as misleading earnings claims, inventory loading, snowball systems, internal consumption- are not or are not expressly addressed by European unfair competition law. This will provide the basis of understanding for chapter IV on the industry lobby concerning the European pyramid scheme definition as enshrined in the Unfair Commercial Practices Directive.

Thirdly, the sections concerning industry self-regulation and voluntary codes of conduct were elaborated upon as a specific way to exercise control over unfair commercial practices, paving the way towards understanding the dossier on the direct selling industry's self-regulatory efforts (chapter V). 


\section{Dossier 1: \\ The Consumer Rights Directive and the Direct Selling Industry Lobby}





\subsection{Introduction}

The present chapter looks into the shaping of the fairly recently adopted Directive 2011/83/EU on Consumer Rights (CRD) with a view to assess the extent to which the direct selling industry advocacy has succeeded in influencing this particular piece of legislation. To that end, the broader political context of the Directive's preparation and adoption will be described, starting with the Commission's ambitious intent to revise, systematise and codify the European consumer acquis, pointing out the highly sensitive political and regulatory issues that have been brought to surface by the Commission's paradigmatic shift from minimum to maximum harmonisation. Because of the major political opposition the Commission's intent stirred, the directive had to be slimmed down from a legislative act harmonising a broader terrain of consumer law to a law that regulates only distance and direct selling, although its title would suggest otherwise.

Placed against this backdrop, the lobbying goals of the direct selling industry will be described. These efforts focus on the modernisation of the legislative framework and, inherently, on full harmonisation to reduce compliance costs on the one hand, but also, more importantly, to standardise the level of consumer protection in an effort to abolish barriers to the direct selling channel. Said trade barriers are namely the result of permissive European legislation that have resulted in the discrimination of the sales channel, according to the industry. Lastly, it will be evaluated how efficient the direct selling industry lobby was in influencing European law in light of the degree of harmonisation and the specific provisions of the actual legislative output.

\subsection{The Political Context: the Rocky Road to the Adoption of the Consumer Rights Directive}

Somewhat contrary to its monumental title, the Consumer Rights Directive is a horizontal instrument that systematically regulates distance selling and direct selling through maximum harmonisation. The Directive was adopted as a result of a decade of planning and deliberations that have were started by the European Commission in 2001 with the ambitious view to review European contract law. The Commission's intent behind the revision of the existing acquis was to decrease legal fragmentation by shifting from minimum to maximum harmonisation and to increase consistency in interpretation in 
order to improve the coherency of the legislative framework, thereby contributing to the overall functioning of the internal market. ${ }^{277}$

In particular, the notion of maximum harmonisation was promoted by the Commission's Consumer Policy Programme 2002-2006 to provide 'a more consistent environment for consumer protection across the EU'. ${ }^{278}$ The Commission's new preference for full harmonisation - chimed with the European Parliament and the Council - has manifested in the adoption of Directives 2005/65 on distance selling of financial services and Directive 2005/29 on unfair commercial practices, despite political objections of Denmark and Sweden concerning the latter instrument's negative effect on the existing level of protection. ${ }^{279}$

In parallel to the Commission's highly ambitious endeavour to revise contract law and to possibly codify it in some sort of European instrument which has led to the creation of the Common Frame of Reference (CFR) in 2003, ${ }^{280}$ the review of the consumer acquis continued which at first focused on eight Directives: Directive 85/577 on doorstep selling, Directive 90/314 on package travel, Directive 93/13 on unfair terms in consumer contracts, Directive $94 / 47$ on timeshare, Directive $97 / 7$ on distance contracts, Directive $98 / 6$ on price indications, Directive 98/27 on injunctions and Directive 99/44 on the sale of consumer goods and associated guarantees. ${ }^{281}$ However, the number of directives to be reviewed was soon cut down to four in the Commission's 2008 proposal for Consumer Rights (COM (2008)614), rendering the efforts of the Commission to systematise the consumer acquis already less ambitious. The aim of the proposal was to create a single regime of the Directives on doorstep selling, distance selling, unfair terms in consumer contracts and the sale of consumer goods and associated guarantees through maximum harmonisation.

The 2008 proposal met both political-, consumer- as well as academic objections. The political resistance to maximum harmonisation by Member States was significantly stronger than it was against the adoption of the Unfair Commercial Practices Directive as Member States were concerned that the maximum level of harmonisation set by the Commission on such a wide terrain would decrease the level of protection in cases of many States. ${ }^{282}$ Arguments of academia against the full harmonisation nature of the proposal were very similar to Member States' concerns and concentrated on the fact that

\footnotetext{
${ }^{277}$ Weatherill, S., 'The Consumer Rights Directive: How and why a quest for coherence has (largely) failed', 49 Common Market Law Review (2012) p. 1279-131.8, p. 1283.

${ }^{278}$ European Commission, Consumer Policy Programme 2002-2006, COM (2002)208, OJ 2002, C137/2, p. 11.

${ }^{279}$ Weatherill, S., 49 Common Market Law Review (2012) p. 1279-1318, p. 1284.

${ }^{280}$ Ibid., p.1284-1285.

${ }^{281}$ Ibid, p. 1286.

${ }^{282}$ Ibid., p. 1287-1288.
} 
the matter was not of technical nature and could thus attract high costs while also raising doubts concerning the proper location of regulatory responsibility in Europe. ${ }^{283}$ Consumer organisations were opposed to maximum harmonisation fearing that full harmonisation would reduce consumer rights in certain Member States to the common level defined by the Directive and advocated mixed harmonisation instead. The European Consumer Organisation, BEUC argued that the two key problems with the approach were that economically, there was no evidence to suggest full harmonisation would boost cross-border commerce and that, from a legal perspective, the application of the full harmonisation approach to consumer contract law which is inseparably linked to national civil law is bound to fail. ${ }^{284}$

The proposal failed to secure cross-party support in the European Parliament too: while the European People's Party and the Alliance of Liberals were more in favour, the Socialist and Democrats and the Greens were particularly against the maximum harmonisation nature of the proposal. Socialist MEPs were opposed to plans to harmonise rules on distance selling and direct selling given that Member States would no longer be able to have higher protection standards.

Amidst the political conflicts and intense deliberations, the EP suggested a set of amendments in the course of the first reading of the proposal and, as a result, a compromise was struck in 2011. The compromise meant that the proposal was trimmed down from the merging of four directives to two: Directive $97 / 7$ on distance selling and Directive 85/577 on doorstep selling that in principle were to be fully harmonised, that is with certain exceptions of provisions of minimum harmonisation nature. Following the blessing of the Council, the Directive was officially published in November 2011. The result, as Weatherill remarks, is a Directive that has been limited to the odd merger of distance- and direct selling, the unison of which under the title of "Consumer Rights Directive" is at best a case of misleading advertising. ${ }^{285}$

\footnotetext{
${ }^{283}$ Ibid., p.1287-1288.

${ }^{284}$ BEUC, The European Consumer Organization: The Consumer Rights Directive - How to Get It Right Decision Makers' Guide (2010), p. 1-2. http://www.beuc.org/publications/2010-00534-01-e.pdf (last visited 20 April 2015)

${ }^{285}$ Weatherill, S., 49 Common Market Law Review (2012) p. 1279-1318, p.1289.
} 


\subsection{Priorities for the Direct Selling Industry Concerning the Revision of Consumer Law}

Following the brief summary of the Consumer Rights Directive's long and complicated saga embroidered with severe conflicts, it is time to assess where the direct selling industry stood amidst the political havoc generated by the European Commission's ambitions. The top priorities for the direct selling industry lobby have clearly been to contribute to the creation of a modernised legislative framework for the sector, and implied in the notion of modernisation, to bring the level of harmonisation to a maximum level. Concerning the main priorities, the otherwise divided direct selling industry stood united and represented diverging opinions only in cases that were of less importance.

A modernised framework, suggested FEDSA, should take into account the changes that have occurred in the marketplace since the adoption of the 1985 Directive, as direct selling had evolved further than the traditional door-to-door solicitations. The industry has developed into a thriving distribution channel for consumer products complementing in-store retailing and distance selling. Thanks to the improvement of the sales techniques, direct selling's main feature is the person-to-person contact between seller and consumer, away from fixed retail locations. Modern direct selling relies on this contact with the consumer while also using the opportunities provided by information technologies to foster and maintain this elation. It thereby responds to the expectations of today's informed and reasonably circumspect European consumers who benefit from the wide range of offers provided by direct selling. ${ }^{286}$

Bringing Directive 85/577 up-to-date with the economic reality was considered vital for the industry, given that the Directive only regulated direct selling trade of the 1970s and 1980s and hence, the reform was deemed essential for the modernisation of both the image as well as the legislative framework of the industry within which it operates.

The primary observation of FEDSA in this respect was that Directive 85/577 failed to deliver a level playing field for direct selling in Europe. ${ }^{287}$ A level playing field can be created through full harmonisation which was expected of future Community legislation by the industry, that is at an acceptable level of consumer protection. FEDSA further claimed to expect that the revised legislation would become in all its features a state-of-the-art law complying with $21^{\text {st }}$ century needs, bringing direct selling in line with the objectives of the Lisbon agenda, implementing the policy objective of creating a European retail market and a level playing field between the various sectors of $\mathrm{B} 2 \mathrm{C}$ retail

\footnotetext{
${ }^{286}$ FEDSA Response to the Discussion Paper on the Review on the Directive 85/577/EEC, 29 November 2007, p. 1., http://ec.europa.eu/consumers/rights/docs/ds_resp_FEDSA.pdf (last visited 17 September 2014)

${ }^{287}$ Ibid., p. 1.
} 
trade in the Community. The sections and sub-sections to follow will introduce in detail the specific proposals of the direct selling industry concerning a modern and coherent European legislative framework, starting with the arguments for maximum harmonisation (3.3.1), followed by perhaps more technical suggestions for the regulation of the sector (3.3.2).

\subsubsection{Maximum Harmonisation}

In its response to the Commission's Green Paper (COM (2001) 531 final) on the revision of the consumer acquis already in 2002, FEDSA was supporting the introduction of a uniform set of rules regulating B2C transactions concluded away from the trader's premises. The aim was to achieve a uniform legal environment for the direct selling industry throughout the EU in the spirit of the single market and to thereby increase cross-border direct selling and to create a more competitive market place for consumers, avoiding trading bans.

FEDSA considered that 'the many differing requirements imposed by Member States' legislation to direct selling constituted an unjustified barrier to trade and were the primary factor frequently restricting direct selling businesses to national, rather than truly European, markets. ${ }^{288}$ Directive 85/577 only provided for minimum harmonisation and has therefore been implemented in Member States with differences relating in particular to the minimum value of transactions covered by the rules, to the right of cancellation (in particular, its length and starting point), and as to whether national regulations apply to both solicited and unsolicited sales transactions. Furthermore, since the last recital of the Doorstep Selling Directive codified the freedom of Member States to maintain or introduce a total or partial prohibition on the conclusion of contracts away from business premises, inasmuch as they consider this to be in the interest of consumers, moreover, a "minimum clause" (Article 8) allowed Member States to adopt or maintain more favourable provisions to protect their consumers, while some obsolete and unreasonably restrictive national laws on direct selling have been maintained, claimed FEDSA. Divergences relate to the restriction of the retail channel itself (e.g. the Danish partial ban on doorstep selling), product bans (e.g. the ban of sale of cosmetics or jewellery through direct selling in Austria, the ban of the sale of food supplements through direct selling in Hungary) or concerning the conditions of payment: in France

\footnotetext{
${ }^{288}$ FEDSA Response to the Green Paper on EU Consumer Protection COM (2001)531, 15 January 2002, final, p.4., http://ec.europa.eu/consumers/cons_int/safe_shop/fair_bus_pract/green_pap_comm/responses/busi ness_europe/fedsa.pdf (last visited 17 September 2014)
} 
for example, no money can be collected by the sales person at the moment of the signing of the order form. ${ }^{289}$

FEDSA thus observed that the consequence of minimum harmonisation and the various national regimes was confusion and barriers to both industry and consumers alike. ${ }^{290}$ Business interests were compromised regardless of the size of businesses: for multinational direct selling companies, the lack of full harmonisation meant on the one hand unreasonable extra compliance costs, since they had to devote resources to investigating which rules are valid for each Member State in which they trade and restructure their operations in consequence; and, on the other hand, major operational inefficiencies, since they had to adopt different sales methods in different countries. These problems, claimed FEDSA, were particularly severe for the numerous small/medium sized direct selling businesses, for whom the need to comply with differing legal requirements in different Member States presented a proportionally larger hindrance to cross-border trade than it does to large or multinational businesses. FEDSA therefore asserted that the contemporary legislative regime was anti-competitive, since it could be accommodated by large businesses but militated against the development of cross-border trade by SMEs. ${ }^{291}$

As a consequence, there were consequent restraints on the provision to the public of cross border trade opportunities and on the provision of independent earnings opportunities for every European citizen. More generally, the lack of harmonisation within the EU contributed to the infringement of consumer rights by illegitimate and fraudulent businesses, still according to FEDSA. ${ }^{292}$

All in all, the position of the industry already in early 2002 was that the internal market for direct selling had clearly not been achieved given that the contemporary legal frameworks in Member States impacting direct selling were divergent in both aim and content, wherefore the conclusion could only be the industry's firm call for maximum harmonisation.

The request was re-affirmed in FEDSA's position paper on the revision of direct selling legislation of 16 May 2006, ${ }^{293}$ as well as in its Response to the Discussion Paper on

\footnotetext{
${ }^{289}$ Ibid., p. 3.

${ }^{290}$ Ibid., p. 3.

${ }^{291}$ Ibid., p. 4-5.

${ }^{292}$ Ibid., p. 4-5.

${ }^{293}$ FEDSA Position Paper on the revision of direct selling legislation in Europe, 16 May 2006, p. 1., http://www.docstoc.com/docs/24461580/FEDSA-Position-Paper-on-the-revision-of-direct-selling-legislation (last visited 17 September 2014)
} 
the Review of Directive $85 / 577$ of November $2007 .{ }^{294}$ In it, FEDSA underlined the need for a maximum harmonisation directive in order to create a level playing field with a high (but not the highest possible) level of consumer protection in order to avoid disparities stemming from various national implementations, and to eliminate trading bans by still leaving considerable room for self-regulatory schemes which allow for a higher level of voluntary consumer protection. ${ }^{295}$

In line with FEDSA's position Direct Selling Europe has, after its establishment, also supported the Commission's intent to fully harmonise consumer law. Nevertheless, it also suggested the application of vertical directives governing various sectors, claiming that different marketing methods demand different regulations. ${ }^{296}$ Naturally, DSE was also against direct selling trade barriers which it deemed unjustified and discriminatory and expressed its hope that the new Directive will abolish national restrictions and bans of direct selling. ${ }^{297}$

The result -although not so much of the industry's advocacy but rather of the Commission's campaign to fully harmonise consumer law in Europe- was the Commission's proposal of 2008 for a directive on consumer rights ${ }^{298}$ which indeed was based on full harmonisation. As was described earlier, the adoption of the Consumer Rights Directive itself could only succeed after its scope was considerably reduced to only distance and direct selling, yet even in these fields, certain concessions needed to be made towards Member States in the course of the deliberations to make the Directive politically acceptable. These compromises - the minimum harmonisation provisions concerning additional information requirements, possible exemption of low value transactions and the maintenance of payment bans - were especially difficult to swallow for the industry.

\footnotetext{
${ }^{294}$ FEDSA Response to the Discussion Paper on the Review on the Directive 85/577/EEC, 29 November 2007, p. 1.

${ }^{295}$ FEDSA Position Paper on the revision of direct selling legislation in Europe - 16 May 2006, p.1.

${ }^{296}$ Response of Direct Selling Europe (DSE) on the Discussion Paper on the Review of Directive 85/577/EEC to protect the consumer in respect of contracts negotiated away from business premises (Doorstep Selling Directive) of 3 December 2007, p. 4., http://ec.europa.eu/consumers/archive/rights/docs/ds_resp_dse.pdf (last visited on 17 September 2014)

${ }^{297}$ Ibid., p. 12.

${ }^{298}$ Proposal for a Directive Of The European Parliament And Of The Council on consumer rights $\{$ SEC(2008) 2544\}\{SEC(2008) 2545\}\{SEC(2008) 2547\} COM(2008) 614 final, 2008/0196 (COD), Brussels 8 October 2008.
} 


\subsubsection{Scope of Application and Exemptions}

\subsubsection{Definitions}

Achievement of a clear scope of application, the equal treatment for sellers and sales companies throughout Europe as well as a more specific determination of which type of transactions are covered by the directive had been a key goal for the industry throughout the deliberations, given that various transpositions of the Doorstep Selling Directive resulted in the altering scope of the Directive from Member State to Member State. ${ }^{299}$ The definitions in question concern off-premises contracts, the notion of "consumer" and "trader".

\subsection{Definition of Off-Premises Contracts}

FEDSA has pointed out that the concept of contracts negotiated and/or concluded away from business premises has broadened considerably since the 1980s when the Doorstep Selling Directive was adopted. Home parties as well as social networking events (such as seminars, conferences or informal discussions with colleagues, friends or relatives) have become popular, outdating the expressions "doorstep selling contracts" or "door-todoor contracts". In fact, the common feature of these contracts is the simultaneous physical presence of both a trader and a consumer away from permanent business premises. $^{300}$

FEDSA attached great importance to the definition of off-premises contracts and took the position that it cannot be subject to minimum harmonisation. ${ }^{301}$ Furthermore, it suggested that the definition of off-premises contracts pursue the following policy considerations:

Elements of the definition of modern direct selling should be: (1) person-to-person (2) out of store (3) B2C trade. Doorstep sales is just a sub-category of the modern definition of contracts concluded off premises.

Clarify what direct selling is not: it is not in-store retailing, within the category of nonstore retailing, it is not distance selling (as it is person-to-person), not direct marketing and not automated vending.

\footnotetext{
${ }^{299}$ FEDSA Position Paper on the revision of direct selling legislation in Europe, 16 May 2006, p. 2.

300 Working Document of the Commission: Responses to the consultation on the Council Directive 85/577/EEC of 20 December 1985 to protect the consumer in respect of contracts negotiated away from business premises - Summary of Responses between October 2007 and January 2008, p. 3., http://ec.europa.eu/consumers/rights/docs/doorstepselling_responses.pdf (last visited 17 September 2014)

${ }^{301}$ FEDSA response to the Discussion Paper on the Review on the Directive 85/577/EEC, 29 November 2007, p. 10 .
} 
Cutting the "legal dead wood" of Article 1 of the Directive 85/577 is necessary.

The general notion is to be illustrated by examples which, however, do not restrict the general definition, yet do distinguish between the bread-and-butter of direct selling companies (that negotiate contracts in a consumer's home, workplace, educational establishment or party selling), on the one hand, and on the other hand sales trips or street selling (other than open markets or fairs or on public transport), where most grievances occur, which could be regulated more stringently.

Closing the regulatory gap of repeat transactions through the codification of common technical elements to increase legal certainty and decrease administrative burden. ${ }^{302}$

FEDSA advocacy proved successful in having all proposed elements of the modernised definition adopted by the European legislator (Article 2(8)). However, FEDSA's suggestion concerning the stricter regulation of sales trips or street selling and the regulation of repeat transactions were not accepted.

A further point raised by Vorwerk concerning the definition of off-premises contracts is definitely worth mentioning. The suggestion in question was aimed at countering a common malpractice in direct selling: the case when -although decisive negotiations take place off premises- the contract is actually signed on the trader's premises. Vorwerk suggested that the reformed definition of off-premises contracts focus on the fact that negotiations take place off premises with the simultaneous presence of the consumer and the trader. The suggestion was taken on board by Article 2(8) lit. b) under which off-premises contracts can be defined as B2C contracts for which the offer was made away from the trader's business premises, with the simultaneous presence of consumer and trader.

\subsection{Definition of Consumer and Trader}

The direct selling industry was in favour of the common classical definition of "consumer" (as meaning a natural person acting for purposes which are outside his trade, business, craft or profession) as opposed to consumer organisations and some Member States that suggested the extension of the definition to include legal persons or to cover cases where it is not always clear whether a person acts for business purposes or other purposes (e.g. small traders who sell the same product they consume). ${ }^{303}$ Although the

\footnotetext{
${ }^{302}$ FEDSA response to the Discussion Paper on the Review on the Directive 85/577/EEC, 29 November 2007, p. 10.

303 Working Document of the Commission: Responses to the consultation on the Council Directive 85/577/EEC of 20 December 1985 to protect the consumer in respect of contracts negotiated away from business premises - Summary of Responses between October 2007 and January 2008, p. 2.
} 
common definition of "consumer" was eventually adopted by the Consumer Rights Directive, Recital 13 - as a measure of minimum harmonisation - allows Member States to decide to extend the application of the rules of the Directive to legal persons or to natural persons who are not consumers within the meaning of the Directive, such as non-governmental organisations, start-ups or small and medium-sized enterprises. An exception from the maximum harmonisation nature of the Directive, this clause can be seen as a concession to those Member States which had granted an option to regard certain legal persons as consumers (e.g., Spain, Belgium, Slovakia, Denmark, Greece, and Austria) in their respective laws. ${ }^{304}$ For these Member States, maximum harmonisation would have meant considerable restriction of the consumer's rights. ${ }^{305}$ However, despite this recent development that permits Member States to regard certain legal persons as consumers, legal literature also suggests that one may not conclude that there has been a paradigmatic change in EU law regarding the notion of consumers due to the fact that legal persons are not regarded directly as consumers and given that the need to delimit the notion of consumer to just natural persons continues to be stressed. ${ }^{306}$

For the direct selling industry, although a measure of minimum harmonisation, this measure was not as detrimental as the other derogations from maximum harmonisation due to the fact that Seldia's Codes of Conduct do grant distributors the right to withdraw from the contract within 7 days (Seldia Code of conduct B.g), as well as a buy-back policy upon the termination of the distributor's relationship with the company (Seldia Code of conduct B.h). ${ }^{307}$ Direct Selling Europe's Code also offers distributors a buy-back policy (DSE Code Chapter III, Article 7). ${ }^{308}$

It was also suggested for the definition of "trader" to remain the common definition - as also used in Article 2 of the Unfair Commercial Practices Directive, encompassing 'anyone acting in the name of or on behalf of the trader' as is the case in Directive $85 / 577 /$ EEC given the various categories of intermediaries used by direct selling companies. $^{309}$

\footnotetext{
${ }^{304}$ Research Group on the Existing EC Private Law, Contract II-Principles of the Existing EC Contract Law (Sellier, European Law Publishers, Munich, 2009), p. 59.

${ }^{305}$ Kingisepp, M., Värv, A., 'The Notion of Consumer in EU Consumer Acquis and the Consumer Rights Directive-a Significant Change of Paradigm?', 18 Juridica International (2011), p.44-53., p. 49.

${ }^{306}$ Ibid., p. 49.

307 Seldia's Code of conduct, http://www.seldia.eu/sites/default/files/uploads/content-pdf/seldia_codeofcon duct.pdf (last visited 17 September 2014)

${ }^{308}$ DSE's Code of conduct, http://www.directsellingeurope.eu/sites/default/files/DSE_Code_of_Ethics.pdf (last visited 17 September 2014)

${ }^{309}$ Vorwerk's Response to the Discussion Paper on the Review of Directive 85/577/EEC, December 2007, p.1., http://ec.europa.eu/consumers/rights/docs/ds_resp_Vorwerk.pdf (last visited 17 September 2014)
} 


\subsubsection{Exemptions}

\subsection{Solicited Visits}

The question whether solicited visits should belong under the scope of the new Directive was somewhat controversial and has divided views within the industry. Let us recall (as described in par. 2.2.1.5. above), Directive 85/577/EEC granted consumers the right to withdraw from the contract in the event that the visit of the trader was not expressly requested by the consumer. Under Article 1, the Directive also applied to contracts for the supply of goods or services other than those concerning cases where the consumer requested the visit of the trader, provided that when he requested the visit the consumer did not know, or could not reasonably have known, that the supply of those other goods or services formed part of the trader's commercial or professional activities. However, by way of derogation from the latter provision, under Article 3(3), Member States could refrain from applying the Directive to contracts for the supply of goods or services having a direct connection with the goods or services for which the consumer requested the visit of the trader.

FEDSA first called for the clarification of the scope to avoid confusion (mainly stemming from the divergent means of implementation $)^{310}$ in its response to the Green Paper in early 2002, but suggested in its Position Paper of 16 May 2006 that the Commission consider the exclusion of solicited visits as those that lack the surprise element of classic direct selling transactions. In 2007, in the Response to the Discussion Paper on the Revision of Directive 85/577, FEDSA claimed that it was opposed to regulatory options such as Article 3(3) of the Directive 85/577 as it was against minimum harmonisation $^{311}$ in general and would have favoured the general exclusion of solicited visits from the scope of withdrawal. However, having recognised that the Commission was considering extending the 1985 Directive to include within the scope of a revised Directive sales made during visits that are solicited, ${ }^{312}$ FEDSA claimed it could accept this under the caveat that direct selling law is fully harmonised and this full harmonisation includes certain exemptions, such as that of low value transactions ${ }^{313}$ (the value threshold set by FEDSA was 400 Euros in 2007).

Direct Selling Europe's position was that solicited transactions are to be exempted from the scope of the Directive given that the surprise element, the feature that under-

\footnotetext{
${ }^{310}$ FEDSA Response to the Green Paper on EU Consumer Protection COM (2001)531, 15 January 2002, final, p. 3 .

${ }^{311}$ FEDSA Response to the Discussion Paper on the Review on the Directive 85/577/EEC, 29 November 2007, p. 13.

${ }^{312}$ Ibid., p. 10.

${ }^{313}$ Ibid., p. 14.
} 
pins the protection granted by law, is missing in case of solicited transactions. DSE argued that in the event that the consumer initiated the trader's visit or expressly accepted it, the consumer is in the position to gather necessary information and is aware in advance of the key conditions crucial for the transactional decision. The situation is thus comparable to an in-store retail transaction, wherefore the consumer does not need extra protection. ${ }^{314}$

According to the Commission Working Document summarising responses to the consultation on the revision of Directive 85/577/EEC, however, Vorwerk, the French and Italian direct selling federations (alongside the majority of Member States, all consumer organisations and academia) have called for the extension of the scope to solicited visits for the sake of clarity. ${ }^{315}$ In its response to the Discussion Paper on the Review of Directive 85/577/EEC, ${ }^{316}$ Vorwerk stated that no distinctions between unsolicited and solicited offers are necessary in order to achieve the objectives of simplification and harmonisation, as well as an adequate level of consumer protection. ${ }^{317}$ Vorwerk argued that 'it is often difficult to find out whether or not the consumer knew or should have known that certain products formed part of the trader's commercial activities or to establish the "direct connection" between the goods requested and those eventually sold.' Furthermore, it was pointed out in the paper that the distinction between solicited and unsolicited sales approaches off premises and the related exemptions have also led to diverging implementation at national level. Lastly, it has been asserted in the Vorwerk position paper that companies that are signatories to the FEDSA European Codes of Conduct for Direct Selling stipulate that consumers are granted withdrawal right in all cases, be the visit solicited or unsolicited. ${ }^{318}$

Eventually, solicited visits have not been exempted from the scope of application in line with the Commission's intent; furthermore, contrary to FEDSA's and DSE's opinion, the European legislator has adopted the view that 'in an off-premises context, the consumer may be under potential psychological pressure or may be confronted with an

\footnotetext{
${ }^{314}$ Response of Direct Selling Europe (DSE) on the Discussion Paper on the Review of Directive 85/577/EEC to protect the consumer in respect of contracts negotiated away from business premises (Doorstep Selling Directive) of 3 December 2007, p. 6.

315 Working Document of the Commission: Responses to the consultation on the Council Directive 85/577/EEC of 20 December 1985 to protect the consumer in respect of contracts negotiated away from business premises - Summary of Responses between October 2007 and January 2008, p. 3.

${ }^{316}$ Discussion Paper On The Review Of Directive 85/577/EEC to protect the consumer in respect of contracts negotiated away from business premises (Doorstep Selling Directive) http://ec.europa.eu/consumers/cons_int/ safe_shop/door_sell/doorstepselling_discussionpaper.pdf (last visited 17 September 2014)

${ }^{317}$ Vorwerk's Response to the Discussion Paper on the Review of Directive 85/577/EEC, December 2007, p. 2-3.

${ }^{318}$ Ibid., p. 2-3.
} 
element of surprise, irrespective of whether or not the consumer has solicited the trader's visit.' 319

\subsection{Contracts for which the Payment is Below a Certain Amount}

The exemption of contracts for which the payment is below a certain amount was an issue that caused considerable debate, even within the industry. Article 3(1) of Directive 85/577 allowed Member States to decide to apply the Directive only to contracts for which the payment to be made by the consumer exceeds a specified amount which may not exceed 60 ECU.

While the direct selling industry agreed that the exemption of low value contracts must be subject to maximum harmonisation, views on the threshold were divided. FEDSA argued for the full harmonisation of a de minimis rule for transactions not exceeding a defined threshold ${ }^{320}$ which FEDSA set at 400 Euros. FEDSA pointed out that the consumer protection rules which led to the 1985 Directive involved big ticket direct sales made possibly under psychological pressure by the trader - not the low value transactions typically concluded by direct sellers affiliated to national direct selling associations. ${ }^{321}$ A threshold of 400 Euros, claimed FEDSA, would ensure the appropriate level of consumer protection and would also reduce the burden on businesses marketing consumer goods and services, who would otherwise be required to use a prescribed cancellation notice more appropriate to high-value transactions. Furthermore, FEDSA suggested the inclusion of a revision clause based on the inflation factor. ${ }^{322}$

FEDSA's member association, the UK Direct Selling Association suggested the threshold be raised to 500 Euros and that it should be index linked; ${ }^{323}$ the Italian DSA, Avedisco, suggested the threshold be adjusted to the economic and monetary inflation in the EU; ${ }^{324}$ whereas the French association was opposed to any threshold since the French legislation that sets no threshold has proven to work efficiently. ${ }^{325}$

\footnotetext{
${ }^{319}$ Recital 21 Directive 2011/83/EU

${ }^{320}$ FEDSA Position Paper on the revision of direct selling legislation in Europe - 16 May 2006, p. 2.

${ }^{321}$ FEDSA response to the Discussion Paper on the Review on the Directive 85/577/EEC, 29 November 2007, p. 12.

${ }^{322}$ Ibid., p. 12.

${ }^{323}$ Response of the Direct Selling Association (of the UK) to the Discussion Paper on the Review of Directive 85/577/EEC of 9 October 2007, p.2., http://ec.europa.eu/consumers/rights/docs/ds_resp_ukdsa.pdf (last visited 17 September 2014)

${ }^{324}$ Response of the Italian Direct Selling Association, Avedisco to the Discussion Paper on the Review of Directive 85/577/EEC of 9 October 2007, p.4., http://ec.europa.eu/consumers/rights/docs/ds_resp_avedisco.pdf (last visited 17 September 2014)

325 Working Document of the Commission: Responses to the consultation on the Council Directive 85/577/EEC of 20 December 1985 to protect the consumer in respect of contracts negotiated away from business premises - Summary of Responses between October 2007 and January 2008, p. 6.
} 
Direct Selling Europe also suggested that low value transactions be exempt and proposed to fix the threshold to economic and monetary inflation and that the threshold be applied consistently throughout the EU. ${ }^{326}$

Vorwerk pointed out that the provision of Directive 85/577 allowing Member States to introduce a threshold value has led to legal fragmentation and it would therefore be useful to harmonise the exemption for low amounts at EU level; however, claimed Vorwerk, 'from a legal point of view, it is impossible to reach full harmonisation with an exemption from the scope of the directive [...] and the only way to achieve full harmonisation in this respect is to explicitly oblige Member States to exempt off-premises contracts below a certain amount from consumer protection rules' but did not define an ideal threshold value. ${ }^{327}$

Although the Commission's original proposal did not introduce any threshold, a provision of minimum harmonisation nature has been inserted into the text through an amendment proposed by MEP Andreas Schwab (EPP) in the Parliamentary phase as part of a compromise that entitles Member States to introduce a threshold value of maximum 50 Euros. The proposed amendment was criticised by the industry for the lack of uniformity and the decrease of legal certainty the minimum harmonisation nature of the clause is to result in. ${ }^{328}$ Moreover, the bargain that FEDSA offered in 2007: the acceptance of the inclusion of solicited transactions within the scope of the new Directive in turn for full harmonisation that includes the 400 Euro threshold had also been largely ignored.

\subsection{Specific Exceptions}

Other exemptions of concern to the industry relate to catalogues, foodstuffs and other perishable products, financial services, the sale of immovable property and timeshare contracts. It must be noted at the offset that FEDSA and the national associations laid less emphasis on the regulation of financial services, timeshare or the sale of immovable property as their members do not sell these types of products.

\footnotetext{
${ }^{326}$ Response of Direct Selling Europe (DSE) on the Discussion Paper on the Review of Directive 85/577/EEC to protect the consumer in respect of contracts negotiated away from business premises (Doorstep Selling Directive) of 3 December 2007, p. 5.

${ }^{327}$ Vorwerk's Response to the Discussion Paper on the Review of Directive 85/577/EEC, December 2007, p. 5-6.

${ }^{328}$ A day before the vote on 24 March 2011, FEDSA issued a press release entitled "Industry leaders call on MEPs to support 4 million Direct Sellers" against the adoption of the said amendment (http://www.seldia.eu/images/pdf/pr_6_23_03_2011.pdf), whereas Direct Selling Europe claimed on 10 February 2011 to regret the fact that the provision was to be of minimum harmonisation nature, http://www.directsellingeurope.eu/sites/default/files/DSE_issue_7.pdf (last visited 17 September 2014)
} 
FEDSA, whose greatest corporate members are (at least partly) operating on the basis of catalogue sales selling mainly cosmetics, claimed that the catalogue exemption must be retained. FEDSA argued that the catalogue exemption, as provided for by Directive 85/577 does not involve any watering down of the consumer's rights, since the exemption does not apply unless both the catalogue and the contract clearly inform the consumer of his right to return the goods or otherwise cancel the contract during the cooling-off period. This exception is, however, essential to the well-functioning of direct selling. It is the foundation of direct selling to market goods to consumers through brochures or catalogues, with the expectation that the consumer and the seller will establish a relationship which will result in subsequent transactions. ${ }^{329}$

Direct Selling Europe claimed that a majority of its members use distance means exclusively to provide information, and deemed it necessary to adhere to a clear distinction between a purchase via direct selling and a purchase via distance selling. If a consumer orders products or services of a direct selling company using distance means, the transaction should be classified as a distance selling situation, argued DSE. ${ }^{330}$

The Consumer Rights Directive does not contain the catalogue exemption indicating that FEDSA's plea was rejected by the legislator, creating increased protection and clarity for the consumers.

The retention of the exemption of foodstuffs and other perishable products have been successfully lobbied for by FEDSA, ${ }^{331}$ the Italian ${ }^{332}$ and the UK DSAs ${ }^{333}$ and was codified by Article 3(3) lit. j) of the Consumer Rights Directive.

Concerning timeshare contracts, FEDSA claimed that, if reviewed, Community law should codify the Court's Travel Vac $^{334}$ decision insofar as it gives timeshare purchasers the additional protection of EC law on direct selling in the case timeshare is marketed by direct selling solicitations. However, warned FEDSA, it has to be carefully avoided to mix rules on timeshare and on direct selling. FEDSA therefore supported the proposal for a Directive on the protection of consumers in respect of certain aspects of timeshare,

\footnotetext{
${ }^{329}$ FEDSA response to the Discussion Paper on the Review on the Directive 85/577/EEC, 29 November 2007, p. 16.

${ }^{330}$ Response of Direct Selling Europe (DSE) on the Discussion Paper on the Review of Directive 85/577/EEC to protect the consumer in respect of contracts negotiated away from business premises (Doorstep Selling Directive) of 3 December 2007, p. 10-11.

${ }^{331}$ FEDSA response to the Discussion Paper on the Review on the Directive 85/577/EEC, 29 November 2007, p. 15.

${ }^{332}$ Response of the Italian Direct Selling Association, Avedisco to the Discussion Paper on the Review of Directive 85/577/EEC of 9 October 2007, p.7.

${ }^{333}$ Response of the Direct Selling Association (of the UK) to the Discussion Paper on the Review of Directive 85/577/EEC of 9 October 2007, p. 7.

${ }^{334}$ Case C-423/97 Travel Vac v. Manuel Jose Antelm Sanchis [1999] ECR I-2195
} 
long-term holiday products, resale and exchange. ${ }^{335}$ Where timeshare agreements are negotiated during an excursion or other leisure event, organised by the timeshare seller or a third party (sales trip), FEDSA stressed that their proposed definition of a "direct selling contract" would allow tackling some of the timeshare-specific problems without hurting the core direct selling business that usually operates differently.

Vorwerk, on the other hand, suggested the exemption of timeshare contracts as these contracts are subject to the revised Timeshare Directive. ${ }^{336}$

While FEDSA had no concrete position concerning financial services and immovable property in 2007, the Italian DSA advocated the exemption of these contracts. ${ }^{337}$

Eventually, financial services (Article 3(3) lit. d)), immovable property (Article 3(3) lit. e)) and timeshare contracts (Article 3(3) lit. f)) have all been exempted from the scope of the Directive. The long list of exemptions may well be part of the political bargain which made the adoption of the Directive - with a considerably narrowed scope politically acceptable. ${ }^{338}$

\subsubsection{Information Requirements}

FEDSA was opposed to the introduction of pre-contractual information disclosure obligations in off-premises contracts, considering that the requirement would create a double-layer of information requirements and as such would be unwarranted and unworkable, ${ }^{339}$ and argued that in direct selling the consumer can be sufficiently informed about his/her rights upon conclusion of the contract or the completion of the order form. ${ }^{340}$ Conclusively, FEDSA warned against convoluted lists of items required to be given to consumers to inform him or her about the trader, the product, consumer rights, etc. Directives of a more recent generation, observed FEDSA, show a disquieting trend towards ever longer and ever more complicated catalogues. This trend clearly conflicts with the aspiration of the review exercise intending to streamline European law. ${ }^{341}$

\footnotetext{
${ }^{335}$ Commission Staff Working Document Accompanying document to the Proposal for a Directive Of The European Parliament And Of The Council on the protection of consumers in respect of certain aspects of timeshare, long-term holiday products, resale and exchange IMPACT ASSESSMENT \{COM(2007) 303 final\} \{SEC(2007) 744\} Brussels, 7 June 2007.

${ }^{336}$ Vorwerk's Response to the Discussion Paper on the Review of Directive 85/577/EEC, December 2007, p. 6.

${ }^{337}$ Response of the Italian Direct Selling Association, Avedisco to the Discussion Paper on the Review of Directive 85/577/EEC of 9 October 2007, p. 6.

${ }^{338}$ Weatherill, S., 49 Common Market Law Review (2012) p.1279-1318, p. 1291.

${ }^{339}$ FEDSA Position Paper on the revision of direct selling legislation in Europe, 16 May 2006, p. 2.

${ }^{340}$ FEDSA response to the Discussion Paper on the Review on the Directive 85/577/EEC, 29 November 2007, p. 18.

${ }^{341}$ Ibid., p. 18.
} 
Direct Selling Europe also suggested that the information to be provided to consumers should be concise, clear and understandable, because too much information often puts off or confuses the consumer. With an EU-wide standard information form, companies would finally get the legal clarity they need, argued DSE. ${ }^{342}$

The Consumer Rights Directive, however - consistent with earlier European consumer policy - introduced new pre-contractual information requirements for contracts that are concluded from a distance or through direct selling. The list of information requirements has been considerably extended by Article 6 for off-premises contracts.

When assessing the direct selling industry's lobbying priorities concerning information requirements, two further points are to be discussed: firstly, the matter of repeat transactions and, secondly, Member States' right to impose additional information requirements.

For repeat transactions - situations where a consumer has concluded a first contract away from business premises and subsequently reorders the product (e.g. cosmetics or nutritional supplements) from the same trader using exclusively means of distance communication (e.g. telephone, internet, fax etc.) ${ }^{343}$ - FEDSA, whose corporate members predominantly sell low(er) ticket items such as cosmetics and nutritional supplements that consumers periodically reorder, suggested an exemption from information provision mainly 'to avoid the annoyance of both consumers and traders as well as the resulting administrative burden'. FEDSA's call for the exclusion of repeat transactions from the information requirements was not adopted.

In the meantime, former member Vorwerk (selling mostly durable high-ticket items) took the position that the first contract between the consumer and the trader is to qualify as an off-premises contract, whereas the following contracts negotiated through means of distance communication is to be subject to distance selling rules. ${ }^{344}$

The second unwelcome development for the industry as regards information provision obligations was the inclusion of a minimum harmonisation measure upon the amendment proposed by the Parliament.

In a press release prior to the vote on the amendments - also the one concerning the minimum clause regarding information requirements - scheduled for 24 March 2011, FEDSA called on the Parliament not to support Schwab's amendment reasoning that

\footnotetext{
${ }^{342}$ Response of Direct Selling Europe (DSE) on the Discussion Paper on the Review of Directive 85/577/EEC to protect the consumer in respect of contracts negotiated away from business premises (Doorstep Selling Directive) of 3 December 2007, p. 10-11.

343 Working Document of the Commission: Responses to the consultation on the Council Directive 85/577/EEC of 20 December 1985 to protect the consumer in respect of contracts negotiated away from business premises - Summary of Responses between October 2007 and January 2008, p. 8.

${ }^{344}$ Vorwerk's Response to the Discussion Paper on the Review of Directive 85/577/EEC, December 2007, p. 10.
} 
'the amendments would place direct selling at a disadvantage vis-à-vis other sales channels. As an example, extensive and largely unread information has to be provided for each sale of a good when in-store sellers would not. In today's fast-moving convenience world this will turn off consumers, reduce competition and damage small businesses. It will stifle the sector at a time when it can help create growth in Europe. ${ }^{345}$

The said amendment has, however, been adopted and codified in Article 6(8) stipulating that the information requirements laid down in the Directive are in addition to information requirements contained in Directive 2006/123/EC and Directive 2000/31/EC and do not prevent Member States from imposing additional information requirements in accordance with those Directives.

\subsubsection{Withdrawal Right}

The right of withdrawal, the consumer's right to unilaterally rescind from a contract concluded off premises (or through the means of distance selling) is, besides the precontractual information disclosure obligation, the core legal characteristic of direct selling transactions. In the course of the deliberations of the Directive on Consumer Rights, the priorities of the direct selling industry lobby concerned the starting point and the duration of the withdrawal period. Moreover, an important development proposed by FEDSA Legal Affairs Adviser (at the time) Jens Karsten was the introduction of a standard withdrawal form.

As for the commencement of the withdrawal period, all business stakeholders insisted on the need to distinguish between distance and off-premises contracts due to the fact that the rationale of the withdrawal right differs significantly in these two sales methods. In distance selling, because the consumer has not seen or physically tested the product that had been ordered through means of distance communication, the starting point of the withdrawal right is the delivery of the product. In off-premises transactions however, the consumer does see the actual product demonstration before the conclusion of the contract, but may be subject to psychological pressure to make a purchase which is the ratio legis behind the withdrawal right in direct selling. Conclusively, the direct selling industry argued that the withdrawal right should start at the time the order form

\footnotetext{
${ }^{345}$ FEDSA Press Release 'Industry leaders call on MEPs to support 4 million Direct Sellers' of Wednesday, 23 March 2011, http://www.seldia.eu/images/pdf/pr_6_23_03_2011.pdf (last visited 17 September 2014)
} 
is signed or the contract is concluded by the consumer. ${ }^{346}$ Consumer organisations, on the other hand, said that the withdrawal right should start once the consumer acquires physical possession of the product.

While the Commission's original proposal stipulated in Article 12(2) that the withdrawal right for off-premises contracts start on the day of the signature of the order form, the Parliament amended the text and laid down uniform rules in terms of the commencement of the withdrawal right for sales contracts (be it distance or offpremises transactions) to fall on the day the consumer acquires physical possession of the product (Article 9(2) lit. b)).

As for the duration of the withdrawal right, all business stakeholders underlined the need to fully harmonise the length of the cooling-off period, but while FEDSA preferred a uniform length of 7 calendar days, ${ }^{347}$ the Italian direct selling association advocated 10 calendar days, ${ }^{348}$ similarly to Vorwerk ${ }^{349}$ and DSE $^{350}$ that also suggested 10 calendar days. Based on the Commission's original proposal (Article 12(1)), the European legislator eventually granted consumers a period of 14 days to withdraw from the contract in the CRD (Article 9(1)), a duration twice as long as recommended by FEDSA.

Concerning the duration, FEDSA's second proposal was that the European legislator review the CJEU's Heininger ruling 351 'with a view to allow for the prescription of a time-limit after the conclusion of the contract after which the right of withdrawal cannot be further exercised to help achieve legal certainty for both parties within an equitable time. ${ }^{352}$ While the European Court of Justice in Heininger decided that the withdrawal period does not begin and therefore cannot expire before the consumer has been informed of the withdrawal right, FEDSA - as well as Vorwerk ${ }^{353}$ - referred to AG Maduro's Opinion of 21 November 2007 in a court case pending at the time, Hamilton, ${ }^{354}$ in which he proposed to grant Member States the flexibility to fix a delay within which

\footnotetext{
346 Working Document of the Commission: Responses to the consultation on the Council Directive 85/577/EEC of 20 December 1985 to protect the consumer in respect of contracts negotiated away from business premises - Summary of Responses between October 2007 and January 2008, p. 7.

${ }^{347}$ FEDSA Position Paper on the revision of direct selling legislation in Europe, 16 May 2006, p. 3.

${ }^{348}$ Response of the Italian Direct Selling Association, Avedisco to the Discussion Paper on the Review of Directive 85/577/EEC of 9 October 2007, p. 7. at 3.

${ }^{349}$ Vorwerk's Response to the Discussion Paper on the Review of Directive 85/577/EEC, December 2007, p. 10.

${ }^{350}$ Response of Direct Selling Europe (DSE) on the Discussion Paper on the Review of Directive 85/577/EEC to protect the consumer in respect of contracts negotiated away from business premises (Doorstep Selling Directive) of 3 December 2007, p. 10.

${ }^{351}$ Case C-481/99 Georg Heininger and Helga Heininger v. Bayerische Hypo- und Vereinsbank AG, [2001] ECR I-9945

${ }^{352}$ FEDSA Position Paper on the revision of direct selling legislation in Europe, 16 May 2006, p. 2-3.

${ }^{353}$ Vorwerk's Response to the Discussion Paper on the Review of Directive 85/577/EEC, December 2007, p. 7-8.

${ }^{354}$ Case C-412/06, Annelore Hamilton v. VolksbankFilder, [2008] ECR-I-2383
} 
they can decide to limit the exercise of the right of withdrawal. This delay would be computed from the date the consumer learnt or ought to have learnt about his rights in order to increase legal certainty in B2C relations. ${ }^{355}$ FEDSA asserted that a three-month longstop period would be a sensible deadline for the expiry. ${ }^{356}$

A successful achievement of FEDSA's lobbying, the European legislator stipulated in Article 10(1) of the Consumer Rights Directive that in case the trader omits to inform the consumer of the withdrawal right, the withdrawal period shall expire 12 months from the end of the initial withdrawal period.

Lastly, the FEDSA proposal - supported by the Direct Selling Association of the United Kingdom - ${ }^{357}$ to introduce a standard withdrawal form was a successful one that has been included in the Annex of the Directive, contributing to the evolution of the European consumer acquis.

\subsubsection{Bans on Payments and Bans on Sales}

National bans and restrictions of the direct sales channel have been one of the most pertinent problems for the industry. At the core of the issue lies the conflict of interest between the liberalisation of trade in respect of the direct selling industry and Member States' freedom to impose stringent regulations in order to favour consumers' economic interests. While the Treaties provide for the free movement of goods (Article 34 TFEU (ex-Article 28 EC)) and services (Article 56 TFEU (ex-Article 49 EC)), the last recital of Directive 85/577 codified the freedom of Member States to maintain or introduce a total or partial prohibition on the conclusion of contracts away from business premises, inasmuch as they consider this to be in the interest of consumers. Moreover, Article 8 stipulated that the Directive shall not prevent Member States from adopting or maintaining more favourable provisions to protect consumers in the field which it covers. Based on this restriction, and in response to abuses of the sales channel, a number of barriers to direct selling have been introduced to Member States' national regimes. The compliance of some of these barriers with the free movement of goods principle has been challenged in front of the European Court of Justice, producing the so-called

\footnotetext{
${ }^{355}$ FEDSA response to the Discussion Paper on the Review on the Directive 85/577/EEC, 29 November 2007, p. 17.

${ }^{356}$ FEDSA response to the Discussion Paper on the Review on the Directive 85/577/EEC, 29 November 2007, p. 17.

${ }^{357}$ Response of the Direct Selling Association (of the UK) to the Discussion Paper on the Review of Directive 85/577/EEC of 9 October 2007, p. 3.
} 
"Buet-line of case law" 358 the conclusions of which will be briefly introduced in the following sub-section (3.3.5.1.) to illustrate why the issue - as a primary reason of lobbying for full harmonisation - was a key priority for the industry lobby throughout the preparation of the Consumer Rights Directive. Thereafter, the issue will be placed into the context of the Consumer Rights Directive and, more generally, secondary EU law (3.3.5.2.).

\subsubsection{Trade Barriers versus Fundamental Freedoms}

According to settled case law, a national measure in a sphere which has been the subject of exhaustive harmonisation at Community level must be assessed in light of the provisions of the harmonising measure and not those of the Treaty. ${ }^{359}$ However, because the field of direct selling was not subject to full harmonisation until the entry into force of the Consumer Rights Directive, national laws imposing barriers to direct selling have all been checked against the free movement of goods principle before June 2014. The present sub-section will provide a very brief overview of the relevant CJEU case law

\footnotetext{
${ }^{358}$ Buet (Case C-382/87 R. Buet and Educational Business Services (EBS) v Ministère public [1989] ECR1235) was a case from 1989 that concerned a French prohibition on canvassing in order to sell educational material where the Court looked at whether the national rule was in breach of the free movement of goods principle and concluded that it was indeed a breach, although the Court deemed it justified.

Buet was followed by TK-Heimdienst (Case C-254/98 Schutzverband gegen unlauteren Wettbewerb $v$ TKHeimdienst Sass GmbH. [2000] ECR I-151) in 2000 - a case in which the CJEU examined whether the free movement of goods principle precludes national legislation which provides that bakers, butchers and grocers may not make sales on rounds in a given administrative district unless they also carry on trade at a permanent establishment situated in that administrative district or in an adjacent municipality, where they offer for sale the same goods as they do in rounds. The Court considered that the Austrian measure was an unjustified breach of the free movement of goods principle.

The third case, Burmanjer (Case C-20/03 Criminal proceedings against Marcel Burmanjer and Others [2005] ECR I-4133) of 2005 was a reference for a preliminary ruling in which the Court examined the compatibility of a Belgian national measure making the itinerant sale of subscriptions to periodicals subject to prior authorization with the principle of free movement and the freedom to provide services.

Lastly, A-Punkt Schmuckhandels (Case C-441/04 A-Punkt Schmuckhandels GmbH v Claudia Schmidt [2006] ECR-I-2093) which too was a request for preliminary ruling, concerned an Austrian measure that prohibited collecting orders for or selling certain goods, including silver jewellery, at private homes.

In neither of the two latter cases could the Court arrive to a conclusion as to whether a breach of the fundamental freedoms occurred and therefore referred the cases back to the national courts, supplying only guidance for the eventual rulings.

${ }^{359}$ e.g.: Case C-322/01 Deutscher Apothekerverband [2003] ECR I-14887. para. 64.; Case C-470/03 A.G.M.COS.MET Srl versus Suomen valtio and Tarmo Lehtinen [2007] ECR I-2749, para. 50.; 9.; Case C-324/99 DaimlerChrysler [2001] ECR I-9897, para. 32.
} 
analysing the compliance of direct selling trade barriers with the EU's fundamental freedoms, i.e. the free movement of goods principle. ${ }^{360}$

In the course of the assessment of the compatibility of national direct selling trade barriers with the free movement of goods principle, the Court relied on its earlier judgments: Buet was decided based on the Court's ruling in Cassis $^{361}$ and was found to be a justified breach of Article 34 TFEU (ex-Article 28 EC), ${ }^{362}$ whereas in the remaining three direct selling trade barrier cases, A-Punkt Schmuckhandels, Burmanjer and TKHeimdienst, the CJEU applied the Keck ${ }^{363}$ formula of 1993. In the landmark Keck decision, the Court assessed a French law that prohibited a certain method of sales promotion and pronounced it was not in breach of Article 34 TFEU. The CJEU indicated that the purpose of the French law was not to regulate trade in goods, ${ }^{364}$ although such legislation could restrict the volume of sales (including sales of products from other Member States). ${ }^{365}$ The Court went on to say that it wanted to stop dissatisfied traders from using Article 34 TFEU to challenge any restriction on their freedom to sell what they wanted, where they wanted and when they wanted. ${ }^{366}$ It said that in view of the increasing tendency of traders to invoke Article 34 TFEU as a means of challenging any rules whose effect is to limit their commercial freedom', even where such rules were not aimed at products from other Member States, it considered it 'necessary to re-examine and clarify its case law on this matter" 367

\footnotetext{
${ }^{360}$ Besides the free movement of goods principle, there is an additional aspect of direct selling that concerns the freedom to provide services which involves the conduct of itinerant activities as was the case in Burmanjer. In Burmanjer the Court found that the national rules on itinerant sales -as measures governing a certain type of marketing- concern the free movement of goods principle mostly, but it cannot be excluded that the rules in question also have "service" aspects. However, the CJEU did not find this fact sufficient to classify an economic operation such as itinerant sales at issue in the main proceedings as "provision of services".

${ }^{361}$ Case 120/78 Rewe Zentrale v Bundesmonopolverwaltung fur Branntwein ("Cassis de Dijon") [1979] ECR 649

${ }^{362}$ The infringement of Article 34 TFEU (ex-Article 28 EC) was justified by the need to protect particularly vulnerable consumers, as the satisfaction of mandatory requirements under Cassis. On the other hand, the Court has pointed out that "normally" (i.e. not in the case of particularly vulnerable consumers) the right to cancel the contract should be sufficient to guard consumers' interest. Hence, for average consumers, there is no need to introduce stricter rules as the Doorstep Selling Directive offers them the appropriate level of protection, according to the CJEU's obiter dictum (in para.12 of the judgment in Buet).

${ }^{363}$ Joined cases C-267/91 and C-268/91. Criminal proceedings against Bernard Keck and Daniel Mithouard. [1993] ECR I-6097

${ }^{364}$ Joined cases C-267/91 and C-268/91. Criminal proceedings against Bernard Keck and Daniel Mithouard., para. 12.

${ }^{365} \mathrm{Ibid}$., para. 13.

${ }^{366}$ Barnard, C., The Substantive Law of the EU: The Four Freedoms ( $4^{\text {th }}$ edition, Oxford University Press, Oxford, 2013), p. 125.

${ }^{367}$ Joined cases C-267/91 and C-268/91. Criminal proceedings against Bernard Keck and Daniel Mithouard, para. 14.
} 
As a result, the Court distinguished "certain selling arrangements" from "product requirements". The notion of "certain selling arrangements" is rather difficult to define: not aimed at regulating trade between Member States, measures that qualify as selling arrangements concern marketing methods: when, where and how traders may sell products. By contrast, rules concerning product requirements or product compositions (such as those relating to designation, form, size, weight, composition, presentation, labelling or packaging) constitute measures of equivalent effect within the meaning of Cassis.

While product requirements always qualify as measures equivalent to a quantitative restriction (hereafter: MEQR), selling arrangements may escape Article 34 TFEU (exArticle 28 EC): according to paragraph 16 of the judgment in Keck 'a national provision restricting or prohibiting certain selling arrangements is not such as to hinder directly or indirectly, actually or potentially, trade between Member States within the meaning of the Dassonville ${ }^{368}$ judgment [and therefore, do not constitute MEQRs], so long as those provisions apply to all relevant traders operating within the national territory and so long as they affect in the same manner, in law and in fact, the marketing of domestic products and of those from other Member States'.. Should a provision be caught by the non-discrimination test in Keck, the violation of Article 34 TFEU (ex-Article 28 EC) may be justified by an overriding public interest enshrined in Article 36 TFEU or by reference to "mandatory requirements" such as consumer protection.

The introduction of the notion of "selling arrangements" (as well as the entire Keck judgment) have been subject to severe criticism for a number of reasons. Barnard has found that, 'with the introduction of selling arrangements, the CJEU has confirmed that there are outer limits to Article 34 TFEU (ex-Article 28 EC) and has carved out an area reserved for national regulators where it is not prepared to intervene, unless there is evidence of discrimination. ${ }^{369}$ Indeed, as we will see in the present section, direct selling trade barriers appear to be areas which have been reserved for national regulators where the CJEU is reluctant to interfere, even if these national laws have the potential to hinder intra-Community trade.

As in all three post-Keck cases concerning direct selling trade barriers the restrictive national measures were considered "selling arrangements", the Court went on to apply its non-discrimination test to observe whether the market access of imported products was hindered to a greater extent than that of domestic products. In TK-Heimdienst, the Court did establish that the access of imported products to the Austrian market was

\footnotetext{
${ }^{368}$ Case 8/74 Procureur du Roi v Dassonville [1974] ECR 837

${ }^{369}$ Barnard C., The Substantive Law of The EU: The Four Freedoms, (2 ${ }^{\text {nd }}$ edition, Oxford University Press, Oxford, 2007), p. 145.
} 
impeded more than for domestic products and hence established an unjustified breach of Article 34 TFEU (ex-Article $28 \mathrm{EC}$ ), but the result of the CJEU's assessment in $A$ Punkt Schmuckhandels and Burmanjer was less clear: in both cases, the Court declared that there was a likelihood that the national rules in question limited the total volume of sales of the concerned goods and consequently, the volume of imported goods was limited too, but this did not suffice to qualify the national measures as MEQRs.

What the Court did pronounce in Burmanjer was that the hindrance or interference with trade between Member States must be significant and certain ${ }^{370}$ to qualify the national rule discriminatory within the meaning of Keck. It is rather puzzling that, in an analogous case, DocMorris, ${ }^{371}$ a case concerning German national legislation that restricted internet sales of medicinal products for human use by pharmacies established in another Member State, the Court ruled that the restriction in respect of nonprescription medicines did constitute a substantial hindrance to the market access and was considered a MEQR for the purposes of Article 34 TFEU (ex-Article 28 EC) which could not be justified. One is left wondering why the Court decided that the German prohibition to sell non-prescription medicines through the internet is to be considered a significant impediment to market access but the Austrian ban of the direct sales of jewellery in private homes not (especially if this may be a more effective marketing method than in-store retail, even according to the Court itself).

Furthermore, it was found irrelevant that the sale in private homes of jewellery of low value might seem more appropriate and efficient than sale in a fixed commercial structure $^{372}$ or that the itinerant sale of subscriptions may be a good way of bringing to consumers' knowledge periodicals from all sources. ${ }^{373}$

It follows from the foregoing that the Court appears more inclined to deem a national measure discriminatory if that measure results in a significant impediment to intra-Community trade - whatever "significant impediment" might mean exactly. In other words, echoing Advocate General Jacob's opinions in Leclerc-Siplec ${ }^{374}$, Schmidberger $^{375}$ and Saeger v. Dennemeyer ${ }^{376}$, the Court has taken the stance that the only measures which breach the Treaty are those which prevent or substantially hinder market access (unless justified). Hence, it is proposed that a de minimis market access test is

\footnotetext{
${ }^{370}$ Case C-20/03 Criminal proceedings against Marcel Burmanjer and Others, para. 41.

${ }^{371}$ Case C-322/01 Deutcher Apothekenverband eV v 0800 DocMorris NV

${ }^{372}$ Case C-441/04 A-Punkt Schmuckhandels GmbH v Claudia Schmidt, para. 22.

${ }^{373}$ Case C-20/03 Criminal proceedings against Marcel Burmanjer and Others, para. 30.

${ }^{374}$ Case C-412/93 Leclerc-Siplec v TFI Publicite [1995] ECR I-179

${ }^{375}$ Case C-112/00 Schmidberger, Internationale Transporte und Planzuge v Republic of Austria [2003] ECR I5659

${ }^{376}$ Case C-76/90 Saeger v Dennemeyer \& Co. Ltd. [1991] ECR I-4221
} 
applied when examining compliance with the Treaty provisions with respect to the four freedoms.

According to critics however, such a test is not in conformity with the aims of the Treaty, namely the establishment of the internal market and the free movement of goods, workers, services and capital. Moreover, it reverses the well-established principle that a de minimis rule does not apply to Article 34 TFEU (ex-Article 28 EC), not to mention how ill-prepared national courts are to carry out a statistical test of this kind. ${ }^{377}$ Lastly, disregarding the fact that a national rule might prevent market access -and the application of Keck, as a wider principle- is dangerous because it takes insufficient account of the dynamic process of opening up markets previously fragmented along national lines. ${ }^{378}$

While for the aforementioned reasons some prefer a more legal test based on causation and remoteness, the Court has not addressed this issue directly and appears to have a rather intuitive approach when it comes to the assessment of market access. Sophisticated economic analyses with regard to the hindrance of market access are not conducted, nor are any legal analyses of remoteness carried out. ${ }^{379}$ The inconsistency of this approach has been confirmed by the differences between the outcome of DocMorris and A-Punkt Schmuckhandels in particular.

All in all, the Court requires substantial hindrance of market access but there is a clear lack of criteria to assess the level of hindrance. While it is already doubtful whether setting a threshold is in conformity with the Treaty aims, it is also unclear how the CJEU carries out the assessment (if at all). The Court's intuitive approach lacks clear guidance on the permissibility of trade barriers and increases legal uncertainty for both the industry and consumers.

\footnotetext{
377 Barnard, C., The Substantive Law of the EU: The Four Freedoms ( $2^{\text {nd }}$ edition, Oxford University Press, Oxford, 2007), p. 145-147.

${ }^{378}$ Weatherhill, S., 'After Keck: Some Thoughts on How to Clarify the Clarification', 33 Common Market Law Review (1996) p. 885-906, p. 894.

379 Barnard, C., The Substantive Law of the EU: The Four Freedoms (2 ${ }^{\text {nd }}$ edition, Oxford University Press, Oxford, 2007), p. 147.
} 


\subsubsection{Trade Barriers versus Secondary Law ${ }^{380}$}

Given trade barriers' negative impact on trade and the legal uncertainty that followed from the CJEU's relevant judgments, the direct selling industry saw a window of opportunity in the revision of consumer acquis. Consequently, the industry has vehemently lobbied against bans and restrictions, and, in particular, against those concerning payment bans and the ban of sale of non-hazardous products in the course of the deliberations concerning the Consumer Rights Directive.

The industry argued for the right of immediate payments and has deemed the ban on payments during the withdrawal right absolutely unjustified. Payment bans impose unreasonable competitive disadvantages on companies which market goods by direct selling methods and also create unfair competition with e-commerce and in-store transactions where no payment restrictions exist. ${ }^{381}$ Furthermore, it is a very real business cost not to be able to collect payment at the time of the conclusion of the contract, especially when goods are provided when contracts are signed, claimed the industry. For businesses to have to return at a later date to collect payment or have to contact the consumer by some other method upon expiry of the withdrawal period imposes such a significant business cost, that it deters companies from even entering the direct selling market. $^{382}$

Vorwerk pointed out that 'the French cooling-off system is particularly restrictive. In France, requesting or obtaining from a consumer, directly or indirectly, on any grounds or in any form whatsoever under any consideration or undertaking prior to the expiry of the cooling-off period is illegal (Article L121-26 of the French Consumer Code). The Supreme Court of Appeals (Cour de Cassation) has in particular prohibited a direct seller from requesting a consumer to sign an authorisation of automatic deduction of his bank account at the moment of signature of the order, even if the account is only deducted after the expiry of the cooling-off period. ${ }^{383}$

\footnotetext{
${ }^{380}$ The section has been based on Steennot, R., 'Are rules prohibiting the doorstep selling of certain goods and prohibiting the itinerant selling of goods and services without prior authorization compatible with the EUTreaty and the Unfair Commercial Practices Directive?' - Universiteit Gent, Financial Law Institute, Working paper Series, WP 2013-04, August 2013, http://www.law.ugent.be/fli/wps/pdf/WP2013-04.pdf (last visited 17 September 2014)

${ }^{381}$ Recommendations by Direct Selling Sector on the proposed Consumer Rights Directive, September 2010, p.3., http://www.seldia.eu/sites/default/files/pdf-documents/pp-4-23-09-2010.pdf (last visited 17 September 2014)

${ }^{382}$ FEDSA response to the Discussion Paper on the Review on the Directive 85/577/EEC, 29 November 2007, p. 23.

${ }^{383}$ Vorwerk's Response to the Discussion Paper on the Review of Directive 85/577/EEC, December 2007, p. 11.
} 
Although the Commission's original proposal for the Directive on Consumer Rights did not contain a permission to maintain or introduce payment bans, as a gesture towards the Member States that do have payment bans - such as Belgium, Bulgaria, France and Greece - the Parliament adopted an amendment to the Commission text which, in the case of off-premises contracts, permits Member States to maintain existing national legislation prohibiting the trader from collecting the payment from the consumer during the given period after the conclusion of the contract. ${ }^{384}$

Besides the right to immediate payment, FEDSA has also lobbied for trade liberalisation and the abrogation of other types of national bans, such as restrictions of the sales method and product bans. In short, what FEDSA requested from the European legislator was that trading restrictions be abolished and the Court's Buet-line of case law be overruled. ${ }^{385}$ Except for certain trade barriers justified by the ordre public clause (such as the prohibition of the sale of firearms or explosives), the sale of non-hazardous products should not be restricted, maintained FEDSA. ${ }^{386}$

FEDSA observed that full harmonisation would be the appropriate solution for the problem as that would disallow Member States to have a margin of appreciation and to thus introduce national measures restricting or banning direct selling. Anticipating the objections and critique this proposal was expected to generate, FEDSA recalled that Article 95 EC Treaty (which was the legal base for EC consumer law reform and is now Art. 114 TFEU) provides in its paragraphs (4) to (9) for a special procedure under which stricter national rules than the agreed common standard may be authorised in exceptional cases. This constitutional safeguard procedure referring to Article 30 EC (Art.36 TFEU) was suggested by FEDSA to be a reassurance for those fearing the effect of full harmonisation. ${ }^{387}$

Although restrictions to direct selling have not been expressly prohibited by the Consumer Rights Directive despite the pleas of the industry, it can be argued that the maximum harmonisation nature of the Directive provides for the abrogation of unjustified national trading bans and restrictions as national measures providing consumers with a higher level of protection ipso iure. It must be made sure -as a possible future task

\footnotetext{
${ }^{384}$ Article 9(3) Directive 2011/83/EU

${ }^{385}$ Case C- 382/87, R. Buet and SARL Educational Business Service (EBS) v Ministère public; Case C-254/98, Schutzverband gegen unlauteren Wettbewerb against TK-Heimdienst Sass GmbH; Case C-20/03, Criminal proceedings against Marcel Burmanjer, René Alexander van der Linden and Anthony de Jong; Case C-441/04, A-Punkt Schmuckhandels GesmbH v Claudia Schmidt

${ }^{386}$ FEDSA response to the Discussion Paper on the Review on the Directive 85/577/EEC, 29 November 2007, p. 24.

${ }^{387}$ FEDSA response to the Discussion Paper on the Review on the Directive 85/577/EEC, 29 November 2007, p. 25.
} 
of the industry lobby- that with the proper implementation of the Consumer Rights Directive, restrictive national measures be annulled to bring Member States' regimes in line with the level of consumer protection prescribed by the Directive.

This line of argumentation is further supported by the Unfair Commercial Practices Directive and the Services Directive ${ }^{388}$ for the following reasons.

The scrutinised national measures undoubtedly fall under the scope of application of the Unfair Commercial Practices Directive for the following two reasons:

First of all, the Court of Justice has considered the measures as those concerning marketing methods: in A-Punkt Schmuckhandels the body of national rules prohibiting selling in private homes, ${ }^{389}$ in Burmanjer, national rules on itinerant sales ${ }^{390}$ are considered "marketing methods" by the Court; in TK-Heimdienst, the Court claims that the national rule regulates 'a particular mode of selling' ${ }^{391}$ whereas in Buet, the CJEU considers the national rule that restricts advertising or a method of marketing. ${ }^{392}$ It follows from the aforementioned definition of commercial practices, that marketing methods fall under the scope of application of the Directive.

Secondly, the standpoint that the direct selling of goods falls under the wide concept of commercial practices is also supported by the European Commission: the Commission started a procedure against Belgium ${ }^{393}$ in which it argued that the Belgian prohibition to sell goods the price of which exceeds 250 Euros at consumers' homes is incompatible with the Unfair Commercial Practices Directive. ${ }^{394}$ The CJEU has agreed that Belgium has failed to fulfil its obligations under Articles 2(b) and (d), 3 and 4 of the Directive 2005/29/EC.

Consequently, national legislation banning the sale of certain products through itinerant selling or limiting doorstep selling or itinerant activities is considered to govern marketing methods and hence falls under the scope of application of the Unfair Commercial Practices Directive. In light of the fact that the Directive is of a maximum harmonisation nature and because it contains a closed list of banned commercial practices that does not entail the ban of selling products through direct selling, nor does it have

\footnotetext{
${ }^{388}$ Directive 2006/123/EC of the European Parliament and of the Council of 12 December 2006 on services in the internal market [2006] OJ L 376

${ }^{389}$ Case C-441/04 A-Punkt Schmuckhandels, para.17.

${ }^{390}$ Case C-20/03 Burmanjer, para. 26

${ }^{391}$ Case C-254/98 TK-Heimdienst, para. 8.

${ }^{392}$ Case C-382/87 Buet, para. 7-8.

${ }^{393}$ Case C-421/12, Commission versus Belgium, [2014] EUECJ

${ }^{394}$ Steennot, R., Are rules prohibiting the doorstep selling of certain goods and prohibiting the itinerant selling of goods and services without prior authorization compatible with the EU-Treaty and the Unfair Commercial Practices Directive? - Universiteit Gent, Financial Law Institute, Working paper Series, WP 2013-04, August 2013, p. 10, footnote 51, http://www.law.ugent.be/fli/wps/pdf/WP2013-04.pdf (last visited 17 September 2014)
} 
any items pronouncing the ban of doorstep selling partially or entirely, Member States do not have the power to introduce further bans (be it product bans or channel bans). Such bans are therefore not in compliance with the Unfair Commercial Practices Directive.

Since the entry into force of the Services Directive, the compatibility of a restriction to provide services with EU law no longer needs to be assessed based on Article 56 TFEU and the Cassis de Dijon/Saenger rule of reason, but on the basis of Article 16 of the Services Directive. ${ }^{395}$ As regards services that fall outside the scope of the Services Directive (e.g. financial services), compatibility of provisions on canvassing, doorstep selling and itinerant selling needs to be ascertained on the basis of Article 56 TFEU and the Cassis de Dijon/Saenger rule of reason. ${ }^{396}$

Article 16 of the Services Directive provides for the freedom to provide services: Member States' obligation to respect the right of providers to provide services in a Member State other than that in which they are established. Restrictions of this freedom, under Article 16(3), may be justified for reasons of public policy, public security, public health or the protection of the environment and in accordance with the principles of non-discrimination, necessity and proportionality.

Although consumer protection is not featured amongst the list of public interests that justify restrictions of the freedom to provide services, some have still argued that, based on the application of the rule of reason, consumer protection can justify restrictions of the freedom to provide services. Opponents of the latter opinion doubted this based on two reasons: firstly as it was the CJEU that created consumer protection as justification for restrictions in the absence of Community rules and secondly, because of the terminological differences between the freedom to provide services (the justifications of restrictions being public policy, public security, public health and the protection of the environment) and the freedom of establishment (mentioning public interest only). ${ }^{397}$

Irrespective of the debate as to whether consumer protection can be considered sufficient justification for the limitation of the freedom to provide services, provisions relating to direct selling are considered commercial practices within the meaning of the Unfair Commercial Practices Directive, which -as an instrument of maximum harmo-

\footnotetext{
${ }^{395}$ Micklitz H.-W., Stuyck J., and Terryn E., Cases, Materials and Text on Consumer Law, (Hart Publishing, Oxford, 2010), p. 16-17.

${ }^{396}$ Steennot, R., Are rules prohibiting the doorstep selling of certain goods and prohibiting the itinerant selling of goods and services without prior authorization compatible with the EU-Treaty and the Unfair Commercial Practices Directive? - Universiteit Gent, Financial Law Institute, Working paper Series, WP 2013-04, August 2013, p. 16.

${ }^{397}$ Ibid. p. 14.
} 
nisation- already precludes Member States from adopting more stringent regulations than those enshrined in the Directive. As pointed out earlier, because financial services do not fall under the scope of application of the Services Directive, cases that concern direct selling of financial services are to be considered under Article 56 TFEU. ${ }^{398}$

\subsubsection{Direct Selling Represents 'Positive Values'}

'Direct Selling is an economic activity that offers value to traders, consumers and the economy as a whole. It should therefore be considered positively. General qualitative references like "pressure sales", "sales under (potential) psychological pressure", "doorstep selling", are inappropriate and unjust and should not be used in the Directive.' 399 This statement was made by FEDSA in defence of the industry and against its discrimination even at the level of semantics. As a result, the wording of the Commission's original proposal in Recital 14:

'In an off-premises context, consumers are under psychological pressure no matter whether they have solicited the trader's visit or not'

was mitigated and changed to:

'In an off-premises context, the consumer may be under potential psychological pressure $[\ldots]$ '

in Recital 21 of the Consumer Rights Directive.

\subsection{Evaluation of the Industry Lobby's Impact on the Consumer Rights Directive}

The purpose of the present enquiry was to assess the degree to which the direct selling industry lobby was successful in influencing the European legislator in the making of the Consumer Rights Directive. The evaluation will be made from the perspective of substantial law as well as from the perspective of applied lobbying techniques.

\footnotetext{
${ }^{398}$ Ibid., p.14.

${ }^{399}$ Recommendations by Direct Selling Sector on the proposed Consumer Rights Directive, September 2010, p.4., http://www.seldia.eu/sites/default/files/pdf-documents/pp-4-23-09-2010.pdf (last visited 17 September 2014)
} 


\subsubsection{Evaluation from the Perspective of Substantial Law}

As introduced in the beginning of the chapter, the priorities of the industry in the course of the revision of the consumer acquis were the modernisation of the legislative framework governing the field of direct selling and, implied in the notion of modernisation, the full harmonisation at an "acceptable level" of consumer protection - for the industry. Efforts on both fields bore only limited fruit.

The industry's plea for maximum harmonisation - modernisation at the political level - concurred with the Commission's ambitious intentions to make a paradigmatic shift from minimum to maximum harmonisation in order to decrease legal fragmentation and to create a coherent system of European private-, or at least consumer, law. This initiative, however, has also meant that the Commission challenged the status quo whereby Member States agreed to the generous use of the EU's legislative competence in exchange for a margin of appreciation within which they could retain a certain level of regulatory power. ${ }^{400}$ However, Member States were not ready for this dramatic redistribution of regulatory power and have therefore agreed to maximum harmonisation only in a much smaller terrain. Furthermore, consumer movements were against the introduction of full harmonisation as well, fearing that consumers will lose important rights in Member States where the level of protection was high. In conclusion, the maximum harmonisation nature of the Directive remained, but not without major political sacrifices: not only was the Consumer Rights Directive trimmed down from eight directives to be harmonised to two, but there were also concessions made even within these two fields. Insertion of minimum harmonisation clauses into the text were clearly the result of political compromises between Member States and the European legislator in their battle for the redistribution of regulatory power, and as such it was out of the direct selling industry's league.

Although not (entirely) the achievement of the industry lobby, the maximum harmonisation nature of the Directive - despite the derogations - is a clear plus for the direct selling sector. As an intended way of ending the industry's discrimination and the abrogation of trade barriers, the industry lobby has yet to ensure that, with the proper and scrupulous implementation of the Directive, national provisions that are more protective than the level prescribed by the CRD be cleansed from the Member States' legal regimes giving way to full harmonisation of $\mathrm{B} 2 \mathrm{C}$ transactions concluded off premises. ${ }^{401}$

\footnotetext{
${ }^{400}$ Weatherill, S., 49 Common Market Law Review (2012) p. 1279-1318., p. 1282.

${ }^{401}$ Weatherill, S., 49 Common Market Law Review (2012) p. 1279-1318., p. 1311.
} 
A second key aspect of the full harmonisation nature of the Directive on the liberalisation of trade is the reduction of negative impacts of the Rome I Regulation ${ }^{402}$ for businesses. Determining the applicable law as that of the consumer's residence in crossborder B2C trade, Article 6 of the Rome I Regulation was seen as the main regulatory obstacle to market integration. This provision is particularly problematic for the business community and the direct selling industry because it compels traders to deal with 28 different regimes. Maximum harmonisation of the rules governing consumer protection in relation to the direct selling channel specifically has reduced the level of complexity for businesses (but not, for instance, in the field of consumer guarantee), although Recital 10 of the Consumer Rights Directives specifically states that it is without prejudice to the Rome I Regulation. ${ }^{403}$

While the issue of full harmonisation has stirred debates within both the Brussels political arena and academia, even the sceptics, like Jan Smits, agreed that the harmonisation of the withdrawal period or the way in which the withdrawal right is exercised are useful. ${ }^{404}$ In this respect, the industry lobby, and particularly FEDSA have made constructive proposals concerning the introduction of a standard withdrawal form or the delimitation of the withdrawal period in case of trader default. Although the latter suggestion does not increase the level of consumer protection (unlike the former), it does increase legal certainty.

Maximum harmonisation was vehemently opposed by consumer movements throughout the entire deliberative process leading up to the adoption of the Directive. Although BEUC claimed that the 'significant reduction of consumer rights will be avoided' and thus, the Directive does add value to European consumer law, it criticised the fact that 'certain protections in some Member States will have to be abolished', ${ }^{405}$ pointing to the example of the trader bearing the cost of return in the event of exercising the right of withdrawal. Further, it was emphasised that the level of protection standards has been lowered in terms of the increased number of excluded products bought by direct selling. The second main line of critique brought forward by BEUC was that, thanks to the level of full harmonisation, Member States are prohibited from adopting more protective

\footnotetext{
${ }^{402}$ Regulation (EC) No 593/2008 of the European Parliament and of the Council of 17 June 2008 on the law applicable to contractual obligations (Rome I) OJ L 177, 4.7.2008,

${ }^{403}$ FEDSA: Commission Green Paper on policy options for progress towards European contract law for consumers and businesses (31 January 2011) p. 1-2. http://ec.europa.eu/justice/news/consulting_public/ 0052/contributions/143_en.pdf (last visited 20 April 2015)

${ }^{404}$ Smits, J. M., 'Full Harmonisation of Consumer Law? A Critique of the Draft Directive on Consumer Rights', 18 European Review of Private Law, (2010) p. 5-14., p. 10.

${ }^{405}$ BEUC: Consumer Rights Directive adopted (1 October 2011) p. 1-2. http://www.beuc.org/publications/ 2011-09818-01-e.pdf (last visited 20 April 2015)
} 
legislation and are to adhere to common standards. Interestingly, in the same breath, BEUC voiced its hope that the fact that all Member States will be covered by the same set of rules would also make any optional instrument obsolete.

Having advocated a differentiated approach to harmonisation -minimum harmonisation at a high level of consumer protection, coupled with full harmonisation only of specific, technical rules (e.g. formal requirements, length of the withdrawal period, the definition of "consumer" etc.) ${ }^{406}$ - BEUC deemed the adoption of the Directive a 'tough compromise' but has praised EU legislators to 'have managed on the whole to make this law another positive step in the history of EU consumer protection' ${ }^{307}$.

Ultimately, supporters of the "mixed" or "targeted harmonisation" were not just European consumer movements but also various Member States. France advocated unambiguous harmonisation targeted at areas agreed by Member States with a high level of consumer protection, whereas Germany as well as academics like Twigg-Flesner suggested that certain areas, such as the withdrawal right and information provision could be included in full harmonisation. ${ }^{408}$

The adoption of the minimum harmonisation measures, namely the provisions concerning additional information requirements (Article 6(8)), the possibility to exempt low value contracts (Article 3(4)) and the possibility to maintain payment bans (Article $9(3)$ ) in addition to the regulation of the commencement of the withdrawal period, were clearly the greatest defeats of the industry lobby. Yet, it may be argued that these provisions loosen the rigidity of the fully harmonised framework, allowing various jurisdictions to come up with divergent solutions and preferences in terms of the level of consumer protection, at least in some areas.

Aspirations of the industry to modernise the legislative framework at a more technical level has also had mixed results. While the high quality input and technical knowledge accumulated about the industry by its advocacy has proven useful and successful in redefining direct selling contracts or in proposing the aforementioned standard withdrawal form and the delimitation of the withdrawal period, a failure of the industry lobby was that the commencement of the withdrawal period was eventually set upon the day of delivery, instead of the day of the signature of the withdrawal form,

\footnotetext{
${ }^{406}$ BEUC, The European Consumer Organization: The Consumer Rights Directive - How to Get It Right Decision Makers' Guide (2010), p. 2-3. http://www.beuc.org/publications/2010-00534-01-e.pdf (last visited 20 April 2015)

${ }^{407}$ BEUC: Consumer Rights Directive adopted (1 October 2011) p. 1-2. http://www.beuc.org/publications/ 2011-09818-01-e.pdf (last visited 20 April 2015)

${ }^{408}$ House of Lords, European Union Committee, $18^{\text {th }}$ Report of Session 2008-09: Consumer Rights Directive: getting it right, Volume I: Report (Published by the Authority of the House of Lords, The Stationary Office Limited, London, 15 July 2009), p. 19.
} 
which was a clear score for the consumer protection lobby. The length of the withdrawal period has also ended up being twice as long as FEDSA had originally requested.

The harmonisation of the withdrawal right was one of the most uncontroversial issues. The majority of stakeholders, even consumer movements and Member States not necessarily backing the full harmonisation approach (i.e. those in favour of targeted harmonisation) supported the harmonisation of the withdrawal right. The measure was particularly welcomed by EuroCommerce as it was deemed especially onerous for small businesses intending to trade cross-border to ascertain the situation across the Member States with regards to the varying rights of withdrawal. ${ }^{409}$

While the principal idea of the withdrawal right's full harmonisation found a wide array of support amongst actors of the political scene, practicalities relating to the exercise of this right were still subject to debate. As indicated, besides the length of the cooling-off period, the commencement and ending thereof were contested. While the Commission's initial proposal of a 7-day withdrawal period mainly favoured businesses and would have been a substantial step back for a number of Member State laws, the extension of the period to 14 days was welcomed by $\mathrm{BEUC}^{410}$ and consumer movements. Furthermore, BEUC argued that the starting point of the withdrawal period should be the same for distance selling and off-premises contracts for the sake of clari$t^{411}$, which is a suggestion that was finally adapted by policymakers despite the direct selling industry lobby's objections. On the other hand, BEUC and consumer organisations were unsuccessful in suggesting that consumers should be allowed to exercise their withdrawal right through the return of products ${ }^{412}$ - in this instance, as indicated, it was the direct selling industry lobby's proposal to require a written statement and the inclusion of a standard withdrawal form that was taken on in the Directive.

The insertion of general information provisions was again essentially widely supported and accepted, although one major point of criticism was that of the perceived information overload. ${ }^{413}$ Pleas and warnings of both FEDSA and DSE concerning information requirements and convoluted lists of items required to be given to consumers to inform him or her about the trader, the product, consumer rights, etc. fell on the deaf

\footnotetext{
${ }^{409}$ Ibid. p. 36.

${ }^{410}$ BEUC, The European Consumer Organization: The Consumer Rights Directive - How to Get It Right Decision Makers' Guide (2010), p. 8. http://www.beuc.org/publications/2010-00534-01-e.pdf (last visited 20 April 2015)

${ }^{411}$ Ibid.

${ }^{412}$ Ibid.

${ }^{413}$ House of Lords, European Union Committee, $18^{\text {th }}$ Report of Session 2008-09: Consumer Rights Directive: getting it right, Volume I: Report (Published by the Authority of the House of Lords, The Stationary Office Limited, London, 15 July 2009), p. 31-32.
} 
ears of the European legislator, although it is questionable whether this resulted in the overall benefit of consumers. Stephen Weatherill also voiced the opinion that 'the EU's commitment to information disclosure has become fetishistic, enlarged Directive by Directive, whereas better regulation pleads for a more selective approach'414, i.e. the consumer does not necessarily enjoy a higher level of protection when receiving an increased amount of information. On the other hand, BEUC was opposed to the exhaustiveness of the list of information requirements, claiming that Member States should be allowed to retain the right to impose wider information provision duties - a legal and political concern that eventually led to the insertion of further minimum harmonisation clauses in Article 6 (7) and (8) whereby Member States are entitled to introduce in their national law language requirements regarding the contractual information, so as to ensure that such information is easily understood by the consumer (Art. 6(7)) and are also allowed to impose additional information requirements in accordance with the Services Directive and the E-Commerce Directive (Art. 6(8)).

\subsubsection{Evaluation of Lobbying Techniques}

Following the evaluation of the industry lobby's performance at the level of substantive law, it is worth looking into more technical aspects of the direct selling sector's advocacy. This sub-section will assess the industry's strategy, messaging and communication, and the role of the national direct selling associations.

It must be noted at the offset that the detailed assessment of FEDSA's and, following its foundation, DSE's (the two competing European trade association's) positions did not reveal any substantial differences in their merits. Aside from minor differences, the two European lobby groups, the national trade associations and the individually lobbying corporation Vorwerk stood united on key issues such as full harmonisation, trade liberalisation or the need for modernisation, revealing that the core interests of the industry were the same, despite the split, at least in terms of consumer law. While FEDSA and its former member, Vorwerk, DSE and the three national direct selling associations seemed to agree on the main priorities, the fight over possible competitive advantages in certain issues was apparent, for example on the exemption of repeat transactions. Although the existence of individual interests and the aspiration to gain competitive advantages is inherent in lobbying, the lack of discipline and a certain degree of loyalty within the industry may be detrimental for the overall outcome.

${ }^{414}$ Weatherill, S., 49 Common Market Law Review (2012) p. 1279-1318., p. 1294. 
Secondly, the low level of national direct selling associations' participation in the industry's lobbying efforts was conspicuous. At least the assessment of publicly available documentation, position papers and responses to consultations has suggested that the direct involvement of national trade associations' may have been rather modest. This finding in itself does not necessarily mean that the national associations have not engaged in (informal) dialogues with national governments and European policymakers. It does, however, highlight a reduced rate of responsiveness in formal discourses.

The industry's strategy in the course of the preparatory process was clearly proactive, based on the pursuit of acceptable solutions. FEDSA participated in the consultations and negotiations from the earliest possible stage and was advocating a concise position already in 2002, six years before the Commission tabled its proposal for the revision of the consumer acquis. The original proposal was one the industry was delighted with given that the industry's interests of full harmonisation and trade liberalisation were aligned with the Commission's intents. However, the Parliamentary stage changed the state of play significantly. As the Commission's proposal proved too ambitious and politically unacceptable, the Parliament's IMCO Committee tabled amendments to reach a compromise. As some of the amendments- notably those that inserted the aforementioned minimum harmonisation provisions- proved overly detrimental for the industry, it had no choice but to switch to a more defensive strategy. Despite the emotional plea of FEDSA communicated in a press release, the amendments were adopted by the Parliament.

Aside from the obvious political struggles and specific regulatory concerns connected to the current case of the Consumer Rights Directive, the industry doing better preCommission proposal than post-Commission proposal was found to be a common phenomenon in lobbying by Simon Levitt, the reason being the industry's tendency to resist the concept of politicisation of its messaging. ${ }^{415}$ According to Levitt's observations, industry does not always include diversity in its messaging when it comes to the European institutions: industry usually creates detailed advocacy documents, the reader of which will have to have prior knowledge of the policy issue that allows him/her to understand the jargon, the abbreviations as well as the complexity of arguments. This communication method fits with the audience in the Commission's case where complexity is welcome as it is the Commission's task to come up with complex and technical proposals. Such advocacy documents and means of communication prove to be advantageous towards the Commission. The European Parliament, on the other hand, has much less attention to detail. Moreover, the industry often fails to build the argument

${ }^{415}$ Interview with Mr. Simon Levitt on 22 October 2013 in Brussels. 
for re-election sufficiently into its communication with the European Parliament. On the other hand, NGOs have become specialists in campaigning and communication, making them even tougher adversaries for the industry. ${ }^{416}$

Having scrutinised the position papers, responses to consultations and press releases of the industry, in my view FEDSA has not made the classic messaging mistake Levitt refers to. The submissions of the industry to the pre-Commission proposal are all at a high level of technicality, containing complex legal arguments. However, the position paper entitled "Recommendations by [the] Direct Selling Sector on the proposed Consumer Rights Directive" 417 of September 2010 (post-Commission proposal) is a considerably simplified and generalised document, especially compared to those communicated to the Commission. The press release ${ }^{418}$ issued by FEDSA (renamed Seldia at the time) in March 2011, right before the parliamentary vote on the proposed amendments, is a communication that makes an emotional plea addressed to the European Parliament requesting the rejection of the proposals detrimental to the industry and the "support [of] 4 million direct sellers".

Seldia (earlier FEDSA) Executive Director Maurits Bruggink also claimed that Levitt's theory is not a plausible explanation for the way the Consumer Rights Directive ended up becoming less favourable to the industry than the Commission's original proposal. The reason for this, according to Mr. Bruggink, is rather that every single piece of consumer rights legislation will get stricter in the Parliamentary stage - this is something that is bound to happen, as consumers' interests score very high politically. In fact, 'consumers tend to score better politically than saving jobs'. ${ }^{419}$

\subsection{Conclusion}

Examination of the nearly-decade-long direct selling lobby preceding the adoption of the Consumer Rights Directive leads to the conclusion that the success of the industry advocacy and the impact thereof upon European law was modest. It must, however, be emphasised that the attempt to revise the European consumer acquis has stirred a debate that called into question the fundaments of the European Union's constitutional

\footnotetext{
${ }^{416}$ Interview with Mr. Simon Levitt on 22 October 2013 in Brussels.

${ }^{417}$ Recommendations by Direct Selling Sector on the proposed Consumer Rights Directive, September 2010

${ }^{418}$ FEDSA Press Release of Wednesday, 23 March 2011: Industry leaders call on MEPs to support 4 million Direct Sellers, http://www.seldia.eu/sites/default/files/pdf-documents/pr-6-23-03-2011.pdf (last visited 17 September 2014)

${ }^{419}$ Interview with Mr. Maurits Bruggink on 2 December 2013 in Brussels.
} 
equilibrium and was of such political weight that the direct selling industry could not possibly influence it substantially.

Paradoxically, however, the direct selling industry advocacy has managed to achieve a certain degree of success in its aspiration for maximum harmonisation, although this was more due to the fact that a political compromise concerning this small industry was much more easily struck than an overarching resolution to introduce a common set of European private law standards. Nevertheless, even in this already pruned terrain of full harmonisation it was necessary to make further cuts and derogations to satisfy Member State and consumer interests.

On the whole, it was observed that while innovative technical suggestions of the industry were likely to be taken on board by the European Commission, it appeared that some key interests of the small and rather controversial sector were prone to be sacrificed under political bargains in the course of the deliberations of the European Parliament and the Council.

That said, a lesson emerging from the assessment of the industry lobby concerning the Consumer Rights Directive is that the industry lobby's partial defeat on political terrains may -to a certain degree- have been the result of its limited ability to exert influence on Member States, whereby the structure and labour division between the European trade association(s) and the national federations may need to be re-thought, as will be argued in chapter VII, in order to increase the efficiency of the industry advocacy in the Brussels political arena. 


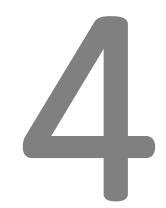

Dossier 2:

The Pyramid Scheme Definition 



\subsection{Introduction}

Pyramid schemes and the pyramid scheme regulation is the single most neuralgic point of the entire direct selling industry. As indicated in the introductory section (1.2.1.), pyramid schemes are marketing or investment frauds in which the real profit is earned, not by the sale of a product, but by the sale of new distributorships. Certain pyramid schemes operate without a product, such as the infamous "Airplane Game" scam in the 1970s and 1980s North America and Europe. However, because the absence of a product is usually a strong indication that a scheme is a pyramid, the vast majority of pyramid promotional schemes are camouflaged as legitimate MLM companies and offer a mere token product that is purchased to meet a quota or that is of value to distributors only. ${ }^{420}$

Generally speaking, the ratio legis of any pyramid scheme regulation is to distinguish frauds from legitimate schemes, thereby offering civil law protection to potential victims of the scams. Because the line between pyramid schemes and legitimate MLMs is very fine, it is often difficult to distinguish between an illegal pyramid scheme that is masqueraded as a legitimate MLM and a truly legitimate network marketing company. Assessing the problem, the Federal Trade Commission (the US government agency that promotes consumer protection and combats anticompetitive business practices) observed that 'while economic analysis can reveal if an individual company clearly is operating legitimately or if it clearly is a pyramid scheme, it is difficult to draw an appropriate line in the grey area.' ${ }^{421}$

The aim of any good regulation concerning pyramid schemes is to minimise this grey area that distinguishes good from bad, legitimate MLMs from illegal pyramid schemes, by establishing tight rules that provide for a clear(er) distinction between frauds and legitimate companies. Ambiguity of pyramid legislation increases the grey area and enables the proliferation of illegitimate schemes, casting a negative light on the entire direct selling industry. ${ }^{422}$

Influencing this particular field of unfair competition law is of primary importance for the direct selling industry lobby. The present chapter, therefore, aims to assess the

\footnotetext{
${ }^{420}$ Clements, L., 'Ponzi \& Pyramid', MarketWave (2009), http://www.marketwaveinc.com/viewarticle. asp?id=72 (last visited 17 September 2014)

${ }^{421}$ Federal Register, Revised Proposed Business Opportunity Rule, 16 C.F.R. 437, p. 36. (proposed March 18, 2008) as cited by Thompson, K., MLMHelpdesk.com, 'Legitimate MLM or Pyramid Scheme: How can you tell?' (July 2009), p. 15.,

http://mlmhelpdesk.com/wp-content/Docs/Direct_Selling/MLM_Attorney_Kevin_Thompson_PyramidSchemes-Saving-the-network-marketing-industry-by-defining-the-gray.pdf (last visited 17 September 2014)

${ }^{422}$ Ibid., p. 15-16.
} 
current pyramid scheme regulation under European law: in what direction the industry has attempted to shape pyramid- and MLM regulation and the degree to which the industry lobby has managed to achieve its strategic goals.

Accordingly, the first main section (4.2.) introduces the goals of the direct selling industry lobby in influencing the pyramid- and MLM regulation at the time the Unfair Commercial Practices Directive was being prepared in the context of a competing proposal based on the comparative analysis of relevant Member State laws. The second section (4.3.) examines the concrete legislative output, i.e. the pyramid scheme definition as enshrined in the Unfair Commercial Practices Directive.

\subsection{Competing Regulatory Concepts}

In the framework of the comprehensive revision of the European consumer acquis, and in preparation of the Unfair Commercial Practices Directive, the Commission commissioned VIEW, the Institution for European Economic and Consumer Law, to carry out a comparative analysis of Member State laws to propose optimal regulatory concepts, while other stakeholders were invited to provide input on the regulation of innovative sales methods which gave the direct selling industry lobby an opportunity to advocate its position concerning the shaping of European fair trading law.

The current section looks into the findings of the VIEW Final Report and the direct selling industry's position with regards to the present field of enquiry: the regulation of new marketing methods, i.e. multi-level marketing (MLM) and pyramid schemes.

\subsubsection{The Pyramid Scheme Concept of the VIEW Final Report}

The VIEW study was prepared by the Institution for European Economic and Consumer Law, a Berlin-based consultancy, with the participation of Prof. Hans Micklitz as project manager alongside other renowned legal experts. The Commission-funded study (finalised in November 1999) is a comprehensive report on the legislative revision of the entire field of direct selling based on the comparative analysis of Member States' legislative frameworks. However, in the present chapter the focus will solely be on the suggested regulation of pyramid schemes and MLMs.

The VIEW study, in essence, has called for the extension of scope of the outdated Doorstep Selling Directive and the introduction through European legislation to ban pyramid schemes and to thereby fill in the gaps of Member States' national regulation of pyramid schemes. In this respect, the report remarks that there were early attempts 
already in 1985 to extend the scope of the Directive, yet, 'these efforts failed because some Member States expressed their concern about the classic direct selling business [which the study calls "single-level marketing"] as such and wanted to avoid the impression that the Directive could be understood as legitimising this form of business.' ${ }^{423}$ While single-level marketing models have become more accepted in the meantime, the emergence of new marketing strategies, such as multi-level marketing has changed the situation considerably.

The problem, according to the VIEW study is that although MLMs do bear significant economic importance, these marketing techniques are also criticised for containing elements of illegitimate and thus banned pyramid and snowball systems. These elements in particular are, on the one hand, that MLMs allow, at least in theory, for the erection of an endless ladder of marketing levels, and, on the other hand, that the underlying business strategy is not just based on selling products to final consumers, but also on the aim turnoff turning final consumers into direct sellers and to make them part of the marketing plan. ${ }^{424}$

In the meantime, states the Report, the direct selling industry is fighting to be recognised as a serious business and highlights its entrepreneurial values which help reduce the rate of unemployment by allowing anyone to join the scheme as a direct seller. However, in this way social policy values and the aspects of consumer protection safeguarding from unfair commercial practices and geometrically progressing pyramid schemes get mixed up. ${ }^{425}$ Furthermore, MLM practices make the distinction between the final consumer and direct seller joining the scheme much more difficult to draw, claims the VIEW Final Report, and observes the emergence of a new category of consumers which is not fully covered by the notion of end-consumer or the notion of direct seller. ${ }^{426}$

For the aforementioned reasons, the modernisation of the direct selling legislative framework was deemed necessary and, accordingly, it was suggested that the coherence between direct selling and distance selling be increased besides the introduction of the timely regulation of the new marketing techniques. ${ }^{427}$

In this respect, the authors of the VIEW Final Report emphasised the need to rethink the concept of "consumer" in direct selling and the MLM- and pyramid structure

\footnotetext{
${ }^{423}$ VIEW Final Report (Micklitz-Monazzahian-Rossler): Door To Door Selling - Pyramid Selling - Multi Level Marketing Contract No. A0/7050/98/000156 A Study Commissioned By The European Commission Final Report Volume I: Outline Of A Possible Approach To Regulation, November 1999, p. 3., http://ec.europa.eu/consumers/cons_int/safe_shop/door_sell/sur10_01.pdf (last visited 17 September 2014)

${ }^{424}$ VIEW Final Report, November 1999, p. 3.

${ }^{425}$ Ibid., p. 3.

${ }^{426}$ Ibid., p. 3.

${ }^{427}$ Ibid., p.5-6.
} 
to tackle the problem emerging from the consumer being recruited as a direct seller into the system. While, according to MLM companies, the average income of a direct seller is low, their activities as direct sellers fall outside the scope of consumers (and fall within that of traders) and are thus not safeguarded as a consumer but are treated no differently from an ordinary corporation with employees and high sales from a legal perspective. ${ }^{428}$ It was for this reason that the VIEW Report suggested the introduction of a "consumer/direct seller" status to provide a bridge between the two concepts as a crucial problem for MLMs. This status was not meant to be temporary and it was suggested that, if the "consumer/direct seller" is successful in his business, he becomes a direct seller. ${ }^{429}$

The definition of pyramid schemes and snowball systems the VIEW Final Report proposed is the following:

'1. A system under which a person gives any valuable consideration and receives the right to sell goods, services or rights of participation, and can legitimately expect to receive an advantage from recruiting other persons into this system where such recruitment is unrelated to the sale to final consumers who do not have to purchase in order to join the system, shall be prohibited. This prohibition covers in particular:

a) systems in which the participants receive a bonus for introducing a new participant into the system;

b) systems in which the participants receive a commission related to the initial investment (e. g. starter kits, training courses) which the new participant whom they have introduced undertakes;

c) systems in which the participants receive a commission related to the continuous purchases of the new participants whom they have introduced in the system.

2. A scheme which is not centrally organised and in which there exists no central beneficiary is prohibited unless the consideration is of minor value.'

The definition is meant to cover both pyramid- and snowball systems as schemes where the participant receives the right to sell goods, services (pyramid) or rights of participation (snowball). ${ }^{430}$

The term "valuable consideration" means either an initial investment (such as a starting fee) which might suggest the geometric progression of the scheme but does not qualify a system a pyramid in itself or it can be a subsequent investment (the purchase of

\footnotetext{
${ }^{428}$ Ibid., p. 6-7.

${ }^{429}$ Ibid., p. 6.

${ }^{430}$ Ibid., p. 26.
} 
goods regularly to keep the license or on occasions to get a higher rank), which may be seen as a regular business cost. The money can be paid to any participant of the system vertically or horizontally. Vertical payments or headhunting fees contain an element of chance and are to be considered illegal, whereas horizontal payments (for example for starter kits, administration or trainings) may occur often and, in case the payments are adequate counter performances, they do not qualify a scheme as a pyramid. ${ }^{431}$

"Receiving the right to sell goods, services or rights of participation", as mentioned above, is a term designed to catch both pyramid- as well as snowball systems. The counter-performance that the investor receives may be direct (an automatic performance connected to the business, or the continued right to participate) or indirect (not automatic, but depends on chance). While snowball systems combine the two features, the requirement can also be met by legitimate schemes as this term is only part of a complex requirement-system. The main characteristic of pyramid- and snowball systems is the connection between profit and recruitment. ${ }^{432}$

"Legitimate expectation", according to the proposal, is the motivation of the participant to have a normative basis, i.e. he must have a reason to believe he can make profit. ${ }^{43}$

"Recruiting other persons" may be the indication of a pyramid scheme, but is not an illegal act per se. A pyramid scheme recruits and encourages others to recruit and is thus a scheme that tries to progress its own distribution network. ${ }^{434}$

The term "any possible advantage unrelated to sales" may be explained as one including a wide array of advantages:

- Investment without buy-back - in the form of an entry fee or the requirement to purchase stocks; this requirement must be in the context of "harming consumers";

- Market saturation - Direct sellers suffer if they have to purchase goods but cannot sell them;

- Aleatory elements - if profit derives mainly from recruitment;

- Progression of system more important than the sales, i.e. if direct sellers also make profit through recruitment, not just the company ("profit inside the chain"). Again, connection between remuneration and the progression of the system is what matters. $^{435}$

\footnotetext{
${ }^{431}$ Ibid., p. 27-28.

${ }^{432}$ Ibid., p. 29.

${ }^{433}$ Ibid., p. 29-30.

${ }^{434}$ Ibid., p. 30-31.

${ }^{435} \mathrm{Ibid}$., p. 31-34.
} 
Remuneration connected to recruitment directly or indirectly may manifest in various forms, and, similarly, the level of causation may also be different in each case; however, the way it reaches the objective of prohibiting pyramid schemes must be determined. The forms of remuneration connected to recruitment may be as follows:

- Headhunting fee - A compensation which the company pays for the introduction of new participants into the scheme, creating a direct link between recruitment and geometric progression and as such, may be considered illegal. ${ }^{436}$

- Compensation for the initial investment - Remuneration may take the form of a commission derived from new recruits' initial investments (e.g. purchase of a starter kit) and may therefore be a hidden headhunting fee. This notion is considered illegal in countries where there is a broad understanding of the link between recruitment and remuneration. ${ }^{437}$

- Compensation for goods purchased for own consumption (Internal Consumption) Granting remuneration for goods purchased by the participant for his own consumption is a much debated issue. It is not a legal obligation for participants to consume the company's products but rather the result of moral pressure.

- Although there is no direct link between remuneration and recruitment here, as remuneration does not follow recruitment, there is a causal link between the two elements as the profit raises with the increase of recruits. Conclusively, the notion of internal consumption is forbidden because it creates profit within the system whereas profit should be made through sales outside the system. ${ }^{438}$

- Commission for product orders - In an effort to avoid being caught as pyramid schemes, companies may not pay headhunting fees, but provide commission based on the products ordered by the participant and his downline. The benchmark may be more easily reached with a larger downline, therefore, the participant may be indirectly motivated to increase recruitment. The effect of this remuneration system is identical to that of a headhunting remuneration system: participants are to recruit new participants and sales not made outside the system, but rather within the scheme. ${ }^{439}$

\footnotetext{
${ }^{436}$ Ibid., p. 34-35.

${ }^{437}$ Ibid., p. 35.

${ }^{438}$ Ibid., p. 35-36.

${ }^{439} \mathrm{Ibid}$., p. 36-37.
} 
- Commission for sales of products to consumers - The connection between remuneration and recruitment must only be prohibited if the remuneration is unrelated to the sales to final consumers who purchase goods for their own consumption.

Lastly, chain-letter systems without a central beneficiary (e.g. a company to organise and profit from the scheme) where new participants expect profit from introducing new members and advancing geographical progression are games of chance but differ from pyramids and snowball systems in the sense that there is no central organiser who receives advantages from the system and where the promoter has nothing to risk. Participants of chain-letter systems, on the other hand, make investments which they risk losing. The study concludes, however, that chain-letter systems should be outlawed only in the case when the investment and therefore the potential loss is considerable as is the case in pyramid- and snowball systems.

Besides regulating illegal schemes, the VIEW Final Report proposed the development of a concise MLM regulation and suggested two regulatory options.

According to the first alternative, an MLM terminology and regulation is to be drawn up. First and foremost, terminology (such as "participant") and definition is required of the consumer who seeks business opportunities. Similarly, a term and definition for direct seller, the person with whom the consumer enters into contractual relations, is needed. Particularly the definition of participants must be drawn up to apply to entrants to the MLM system who lose their statuses as consumers alongside with protective consumer rights and become direct sellers (i.e. traders) but the new status does not correspond to their real position. Sufficient protection must be granted to participants, concludes the VIEW Final Report, either through raising standards regarding information disclosure about the business activities to consumers who are to become direct sellers or some direct sellers must be put on the same level as consumers, providing them with the same level of protection. ${ }^{440}$ Furthermore, safeguards must be established such as the limitation of the number of allowed levels (for increased transparency), the payment of remuneration related only to sales to final consumers, the introduction of a buy-back guarantee, the exclusion of entry fees, the prescription of companies' obligation to control their marketing systems or the obligation to make own sales. Appropriate civil law regulations such as the provision of pre-contractual and contractual obligations, withdrawal right, recruitment or guarantees must be put in place. ${ }^{441}$

\footnotetext{
${ }^{440}$ Ibid., p. 40-41.

${ }^{441}$ Ibid., p. 40-52.
} 
The second alternative proposed in the study was the establishment of a set of mandatory requirements through the standardisation of marketing. With recruitment remaining the most sensitive issue for MLMs, the marketing system of which is, at least in theory, still open to geometric progression, it must be ensured that enticement and aggressive practices be avoided in the course of the recruitment; direct and indirect headhunting fees are not to be paid and the remuneration system must be kept transparent. Presumption of compliance with the marketing standards would equal to the presumption of legality, suggested the Report.

\subsubsection{The Direct Selling Industry's Position}

The European legislator's intention to regulate new marketing practices and to thereby draw up the benchmark criterion of legality distinguishing multi-level marketing from fraudulent schemes has called for firm advocacy action from the direct selling industry.

Given the strategic importance of the matter, it was not only the European direct selling trade association (FEDSA at the time) and its corporate members and national associations that were advocating the industry position, but the World Federation of Direct Selling Associations (WFDSA) entered the ring too. (As the deliberations and the adoption of the UCPD preceded the industry split, there was a uniform position communicated by the industry.)

In an effort to communicate a well-grounded and clear position upon the invitation from the European Commission's Unit responsible for the protection of consumers' rights within DG XXIV to assist the Commission services and its external consultancy in evaluating existing legislation, ${ }^{442}$ FEDSA has commissioned a law firm, Oppenheimer Wolff and Donnelly LLP with the support of Amway Corporation to prepare a comparative legal analysis of selected Member State legislation impacting the direct selling industry and the multi-level marketing sector which was published on 16 March 1999 in Brussels. The document not only represented the industry's position but it also became an important frame of reference for the VIEW Final Report (published in November 1999), which also adopted the entire terminology of the FEDSA Study with the exception of the pyramid scheme definition.

The World Federation's submission to Directorate A (Consumer Policy, Health and Consumer Protection Directorate) prior to the hearing held in March 2000 provided a response and analysis of the VIEW Final Report addressing particular issues in the Report and endorsing the FEDSA legal analysis. According to the submission, a

\footnotetext{
${ }^{442}$ Study prepared on behalf of the Federation of European Direct Selling Associations by Oppenheimer Wolff and Donnelly LLP with the support of Amway Corporation, Brussels, 16 March 1999, p. 5-6.
} 
further aim was to give a global view of direct selling and to thereby provide the reader with insights into the methods of doing business. ${ }^{443}$

The two documents together provide a comprehensive overview of MLM regulation with the FEDSA legal study giving a comparative analysis of selected Member States' laws, and the WFDSA submission bringing a view of relevant US legislative trends, regulation and case law as well as the technical expertise and experience developed on the actual and lawful operation of MLMs.

In terms of the pyramid scheme regulation, the Study prepared on behalf of FEDSA called for a clear distinction between legitimate and illegitimate schemes and suggested that a more comprehensive approach is needed to protect consumers from fraudulent businesses. ${ }^{444}$ It proposed the establishment of a uniform legislative framework that provides clear safeguards and the possibility of an informed choice for the new entrants to the schemes whereby a cooling-off period and a buy-back policy is required alongside information disclosure obligations to ensure transparency. ${ }^{445}$

The suggested wording proposed by the FEDSA Study glossary of the pyramid scheme definition was laid on the foundations of US federal law and reads as follows:

'Any plan or operation in which a participant pays or promises to pay for the opportunity to receive compensation, which is derived primarily from the person's introduction of other persons into a plan or operation, rather than from the sale of goods, services or intangible property, by the participant or other persons introduced into the plan or operation.' ${ }^{446}$

Similarly to the VIEW Final Report, the industry studies too have provided a technical analysis of the new marketing practices and the building blocks of future legislation. The assessed elements are the following:

1. Professional/Amateur Direct Sellers: Let us recall, a key observation made by the VIEW Final Report was that newly recruited direct sellers, who have just made the transition from their status as consumers to direct sellers (traders) should have a separate legal status and be subject to protection as they should not be

\footnotetext{
${ }^{443}$ World Federation Of Direct Selling Associations (WFDSA) Submission To Directorate A - Consumer Policy, Health and Consumer Protection Directorate - General European Commission; Subject: Door to Door Selling - Pyramid Selling - Multilevel Marketing; Hearing 15 and 16 March 2000, p. 1., http://www.wfdsa.org/library/index.cfm?fa=pyramidselling (last visited 17 September 2014)

${ }^{444}$ Study prepared on behalf of the Federation of European Direct Selling Associations by Oppenheimer Wolff and Donnelly LLP with the support of Amway Corporation, Brussels, 16 March 1999, p. 15.

${ }^{445}$ Ibid., p. 27.

${ }^{446}$ Study prepared on behalf of the Federation of European Direct Selling Associations by Oppenheimer Wolff and Donnelly LLP with the support of Amway Corporation, Brussels, 16 March 1999, p. 31.
} 
held accountable to legal requirements that apply to de facto traders.

However, according to the FEDSA Study, solely German law had made a distinction between different categories-professional and amateur- of direct sellers. ${ }^{447}$ Salespeople, says the WFDSA submission, may be divided into 7 categories depending on their personal motivation. Accordingly, WFDSA distinguishes "discount buyers" (those who join as sales people but in reality do so to buy the company's products at the wholesale or discount price accorded members of the salesforce) from, for example, "careerists" who work full-time in a direct sales business or those who join because of their belief in the company's products. Categories may overlap, salespeople may move from one category to the other and, therefore, companies do not have statistics on the size of each category. ${ }^{448}$

Salespeople are protected around the world by two sets of laws, i.e. laws to protect them in their consumer roles and laws to protect them in their salesperson roles. They are also protected in both capacities by the industry's Codes of Conduct, maintained WFDSA, implying that extra protection for certain categories of direct sellers is neither possible, nor necessary. ${ }^{449}$

Further to this matter, in response to the VIEW Report's proposed introduction of the new, protective status of "consumer/direct seller" and in line with the WFDSA position, the French DSA claimed in the course of the Commission's hearing that, instead of diluting the distinction between direct sellers and consumers, there must be a clear threshold for the consumer to become a direct seller. The direct seller must conclude a formal contract with a 14-day withdrawal period and has to receive adequate training offered by the companies. ${ }^{450}$

At the same time, the UK DSA underlined that the 'protective measures have to be fit for purpose in that direct sellers must be protected from making an imprudent investment in a fraudulent scheme, but they need not to be protected from a business opportunity. Their investment is modest; they have a contract; the earning proposition is not misleading; it is fair, honest and legal; they have a

\footnotetext{
${ }^{447}$ Study prepared on behalf of the Federation of European Direct Selling Associations by Oppenheimer Wolff and Donnelly LLP with the support of Amway Corporation, Brussels, 16 March 1999, p. 28.

${ }^{448}$ Ibid., p. 2.

${ }^{449}$ Ibid., p. 4.

${ }^{450}$ European Commission, DG Health and Consumer Protection: Hearing: Door to door selling-Pyramid schemes-Multi-Level Marketing, Analysis of the written submissions prior to the Commission's hearing and the statements made during the Commission's hearing 15-16 March 2000, Brussels, p. 10., http://www.scribd.com/doc/38555103/European-Commission-on-Multi-level-marketing-and-Pyramidschemes (last visited 17 September 2014)
} 
right to withdrawal for a certain period of time to cancel the contract; and any time thereafter, they can send back any unsold goods and be refunded here. ${ }^{351}$

2. Structure of Operation: One of the main resemblances between MLMs and pyramid schemes is their progressive structure, but the structure in itself is not necessarily the indication of fraud. The FEDSA Study revealed that a "progressive" or "geometric" structure was an important element in German, French and Spanish laws and, interestingly, it was found that Spanish law had set the number of distributors between the manufacturer and wholesale distributor at one. ${ }^{452}$

WFDSA, on the other hand, asserted that there was no correlation between the number of levels in a multi-level direct sales company and pyramid schemes. Profits are derived from retail sales and the group sales volume (override/bonus) in multi-level organisations. The number of levels is not indicative of a pyramid scheme and the override/bonus amounts are based on decreasing percentages. ${ }^{453}$

3. Emphasis on Transparency: It is perhaps undisputed that MLM compensation plans and sales systems are often highly complicated and less transparent. While the industry Codes stipulate that the "transparency of operations" must be provided for by thorough information disclosure for direct sellers in the form of written contracts, various Member State laws, claims the FEDSA Study, were found to have attached various degrees of importance to the requirement of transparency. ${ }^{454}$

4. Legitimate Business Test: An element helpful in the establishment of the legality of a scheme was that in certain Member States, like France and Spain, there existed an assumption that the sales system was to serve the purposes of a "legitimate business", ${ }^{455}$ asserted the FEDSA Study.

5. Recruitment Fees: The legality of recruitment or headhunting fees is a question of key importance in establishing whether a scheme is fraudulent.

The FEDSA Study has found that while some Member States (like Germany

\footnotetext{
${ }^{451}$ Ibid., p. 10.

${ }^{452}$ Study prepared on behalf of the Federation of European Direct Selling Associations by Oppenheimer Wolff and Donnelly LLP with the support of Amway Corporation, Brussels, 16 March 1999, p. 27-28.

${ }^{453}$ World Federation Of Direct Selling Associations (WFDSA) Submission To Directorate A - Consumer Policy, Health and Consumer Protection Directorate - General European Commission; Subject: Door to Door Selling - Pyramid Selling - Multilevel Marketing; Hearing 15 and 16 March 2000, p. 8.

${ }^{454}$ Study prepared on behalf of the Federation of European Direct Selling Associations by Oppenheimer Wolff and Donnelly LLP with the support of Amway Corporation, Brussels, 16 March 1999, p. 27.

${ }^{455}$ Ibid., p. 27.
} 
and Spain) outlawed recruitment fees, UK regulations permitted recruitment fees in case of single-level companies and in the event that recruitment fees in respect to one recruit do not exceed 50GBP. ${ }^{456}$

WFDSA argued that profits are derived two ways by salespeople in multilevel organisations. First, it is based on their retail sales (i.e. the markup between the wholesale price they paid their supplier and their price to the consumer). Second, salespeople receive compensation, most often called overrides or bonuses, which are based on their group sales volume. ${ }^{457}$ If eighty or more per cent of compensation is based on sales, claimed WFDSA, one cannot have a pyramid scheme. Pyramid schemes are frauds where ninety-nine per cent of the revenue generated is not on sales (but e.g. on inventory loading, training fees, headhunting fees). Pyramid schemes do not even reach five per cent in terms of sales to the ultimate consumer. ${ }^{458}$

Headhunting or recruitment fees, payments made by a recruit to the scheme organisers which are shared back to the recruiter for the mere act of recruiting a participant into the scheme, are one of the main hallmarks of pyramids that try to disguise themselves as legitimate MLMs, according to WFDSA. ${ }^{459}$

6. Entry Requirements: Permissibility of various entry requirements -as possible indicators of a pyramid scheme- differed from Member State to Member State, observed the FEDSA Study. Entry fees were outlawed in France, whereas in Spain they were permitted, if market-related; in Belgium, entry fees were subject to court consideration if excessive and non-refundable, and not mentioned under German case law. ${ }^{460}$ Initial inventory requirement was illegal under French law, permitted in Spain if refundable, permitted, but subject to limitations in the UK, whereas Dutch law had a general prohibition on the inducement of participants from incurring financial obligations beyond their means. ${ }^{461}$

\footnotetext{
${ }^{456}$ Ibid., p. 27.

${ }^{457}$ World Federation of Direct Selling Associations (WFDSA) Submission To Directorate A - Consumer Policy Health and Consumer Protection Directorate - General European Commission; Subject: Door to Door Selling - Pyramid Selling - Multilevel Marketing; Hearing 15 and 16 March 2000, p. 7.

${ }^{458}$ European Commission, DG Health and Consumer Protection: Hearing: Door to door selling-Pyramid schemes-Multi-Level Marketing, Analysis of the written submissions prior to the Commission's hearing and the statements made during the Commission's hearing 15-16 March 2000, Brussels, p. 9.

${ }^{459}$ World Federation Of Direct Selling Associations (WFDSA) Submission To Directorate A - Consumer Policy Health And Consumer Protection Directorate - General European Commission; Subject: Door to Door Selling - Pyramid Selling - Multilevel Marketing; Hearing 15 and 16 March 2000, p. 8.

${ }^{460}$ Study prepared on behalf of the Federation of European Direct Selling Associations by Oppenheimer Wolff and Donnelly LLP with the support of Amway Corporation, Brussels, 16 March 1999, p. 28.

${ }^{461}$ Ibid., p. 28.
} 
7. Inventory Loading: Inventory loading is the required or coerced purchase of excessive inventory (or sales aids) by a recruit. It is to be noted that all members of all DSAs must provide at least a 90\% refund of net cost of all inventory (and sales aids) purchased in the prior 12 months of the time a salesperson wishes to leave the business, thereby eliminating the possibility of inventory loading when dealing with DSA member companies. Such buy-backs are required under the WFDSA and FEDSA Codes.

8. Exaggerated Earnings Claims: To lure recruits into the business and thereby get them to pay large upfront fees or purchase large amounts of non-refundable inventory, outrageous earnings claims are often made, e.g. 'earn US\$100,000 per month working part-time without retailing'. Such claims also are banned under the WFDSA and FEDSA Codes. ${ }^{462}$

9. Exit Conditions: Exit conditions are crucial in determining whether the participant/direct seller has suffered financial loss or damage. Even if required to invest in the business, in the event that direct sellers can recover their costs, they cannot be considered defrauded. Thus, an important guarantee of legality is the buy-back policy. The FEDSA Study found that while French legislation required a buy-back policy for at least $90 \%$ of the purchase price for at least a year, Belgian courts consider the existence of a buy-back policy in establishing if the scheme subject to enquiry is a fraud. ${ }^{463}$

Based on the judgment in the landmark Amway case, ${ }^{464}$ WFDSA and the US DSA have also concluded that a clear-cut and unequivocal part of the difference between bona fide marketing plans and pyramid schemes was the existence of a buy-back policy. The buy-back requirement was also introduced to the industry's self-regulatory Codes of Conduct as a safeguard against pyramid schemes.

10. Internal consumption: Contrary to the VIEW Report that considered that the notion of internal consumption should be forbidden because it creates profit within the system, whereas profit should be made through sales outside the system, the industry's position was (and has been) -at least to some extent- permissive towards internal consumption. Belief in the company's products is usu-

\footnotetext{
${ }^{462}$ World Federation of Direct Selling Associations (WFDSA) Submission To Directorate A - Consumer Policy, Health and Consumer Protection Directorate - General European Commission; Subject: Door to Door Selling - Pyramid Selling - Multilevel Marketing; Hearing 15 and 16 March 2000, p. 8.

${ }^{463}$ Study prepared on behalf of the Federation of European Direct Selling Associations by Oppenheimer Wolff and Donnelly LLP with the support of Amway Corporation, Brussels, 16 March 1999, p. 28.

${ }^{464}$ In the Matter of Amway Corporation, Inc., et al., 93 F.T.C. 618 (1979)
} 
ally a key element in becoming a direct seller, claimed the industry. This prior experience as a consumer is true for salespeople in both single level and multilevel firms and it is fundamental to all companies in the industry with the exception of some high-ticket, durable product companies selling through full-time salesforces. ${ }^{465}$

In the course of the Commission's hearing, FEDSA maintained that the essence of a direct selling business is that the business develops a network for products for which one feels a personal commitment. The persons who join these systems are likely to be, first of all, consumers. Conclusively, FEDSA Codes allow remuneration systems where the remuneration is based primarily on the sales of goods and services to consumers - including the purchases made by other direct sellers for their personal consumption or use. ${ }^{466}$

The industry's (i.e. the World Federation's) position on snowball systems, or, according to the industry's terminology, "referral sales" followed US law in that it considers that there are two types of referral sales, those legal and those illegal. Under the Uniform Consumer Credit Code and various state statutes, salespeople are allowed to pay consumers for referring someone for the salesperson to call upon indicating that the original consumer recommended the call. This type of referral is legal only if the consumer who had bought a product from the salesperson will receive the payment whether or not the referred parties make subsequent purchases. In other words, a referral scheme is illegal if it is dependent upon an event subsequently occurring (which may or may not happen). ${ }^{467}$

Reacting to the VIEW Report's perceived "misimpression" of United States law, WFDSA underlined that in the US the trend was actually to move away from the introduction of specific MLM regulation and towards the prohibition of pyramid schemes: New Mexico eliminated its multilevel statute in favour of anti-pyramid statute and Georgia also relaxed regulatory requirements for multilevel companies. ${ }^{468}$

\footnotetext{
${ }^{465}$ World Federation Of Direct Selling Associations (WFDSA) Submission To Directorate A - Consumer Policy, Health and Consumer Protection Directorate - General European Commission; Subject: Door to Door Selling - Pyramid Selling - Multilevel Marketing; Hearing 15 and 16 March 2000, p. 4.

${ }^{466}$ European Commission, DG Health and Consumer Protection: Hearing: Door to door selling-Pyramid schemes-Multi-Level Marketing, Analysis of the written submissions prior to the Commission's hearing and the statements made during the Commission's hearing March 15-16, 2000, Brussels, p. 8.

${ }^{467}$ World Federation Of Direct Selling Associations (WFDSA) Submission To Directorate A - Consumer Policy, Health and Consumer Protection Directorate - General European Commission; Subject: Door to Door Selling - Pyramid Selling - Multilevel Marketing; Hearing 15 and 16 March 2000, p. 11.

${ }^{468}$ Ibid., p. 8.
} 
WFDSA maintained that it was not statutory law but the landmark cases together, Koscot $^{469}$ and Amway, ${ }^{470}$ that have set clear standards for the determination of whether a plan is a pyramid scheme or a bona fide marketing plan. In Koscot, the FTC was highly critical of four elements which are the most common abuses in pyramid schemes that try to pass themselves off as legitimate multi-level direct selling companies:

a) large membership fees,

b) front-end loading and inventory loading,

c) programs in which distributors were misled as to the amount of commission they might reasonably earn,

d) programs in which commissions were not based on the sale of product to the ultimate consumers. $^{471}$

The second groundbreaking case, In the Matter of Amway Corporation, Inc., et al. bears relevance in terms of the protective measures that have been developed that distinguish legitimate businesses from pyramid schemes. In the administrative law judge's decision in Amway, three salutary features were pointed out with respect to the Amway program, which also serve as the "Amway Safeguards Rule". Abiding by these three criteria, network marketing and direct sales companies provide themselves with an umbrella of legal protection.

1. Amway required its representatives to engage in retail selling, under the "ten retail customer policy" which appeared in the agreement that representatives signed upon enrolment. This rule required that representatives make 10 sales to retail customers as a qualification for eligibility to receive commissions and bonuses on sales/purchases made by other representatives in their personal sales organisation.

2. Amway required its representatives to sell a minimum of $70 \%$ of previously purchased product before placing a new order. (Amway's rules recognise "personal use" for purposes of the $70 \%$ rule.)

3. Amway had an official "buy-back" policy for unsold, unopened inventory. This policy had some reasonable restrictions, including a specified maximum length of time since the item was originally purchased by the representative and that

\footnotetext{
${ }^{469}$ Koscot Interplanetary Inc., 86 F.T.C. 11106 (1975)

${ }^{470}$ In the Matter of Amway Corporation, Inc., et al., 93 F.T.C. 618 (1979)

${ }^{471}$ Babener, J.A., MLMLegal.com, 'Pyramid: Yes or No?', 2001, http://www.mlmlegal.com/pyramidyn.html (last visited 17 September 2014)
} 
the item was still current in the company's product offerings to consumers. The policy also included a minimal "restocking" fee. ${ }^{472}$

Comparative Table of Positions Concerning the Main Elements of MLM/Pyramid Regulation

\begin{tabular}{|c|c|c|}
\hline Element & VIEW Position & $\begin{array}{l}\text { Aggregated Direct Selling Industry } \\
\text { Position }\end{array}$ \\
\hline Regulatory approach to MLM & $\begin{array}{l}\text { Regulation or standardisation of } \\
\text { marketing }\end{array}$ & Deregulation based on US example \\
\hline New entrants & $\begin{array}{l}\text { Increased protection needed to new } \\
\text { traders through establishment of a } \\
\text { third category "consumer/direct } \\
\text { seller" }\end{array}$ & $\begin{array}{l}\text { No need for increased protection } \\
\text { for new entrants, no need for } \\
\text { establishment of a third category } \\
\text { besides "consumer" and "trader" }\end{array}$ \\
\hline Entry requirements & $\begin{array}{l}\text { - Legal, if considered regular busi- } \\
\text { ness cost (e.g. purchase of starter kit) } \\
\text { (horizontal recruitment fees); } \\
\text { - Prohibition of inventory loading, } \\
\text { buy-back guarantee recommended }\end{array}$ & $\begin{array}{l}\text { - Legal, if regular business cost; } \\
\text { - Prohibition of inventory loading, } \\
\text { buy-back guarantee recommended }\end{array}$ \\
\hline Legality of recruitment & Not illegal in itself & Legal \\
\hline Legality of recruitment fees & $\begin{array}{l}\text { Considered illegal as it is a vertical } \\
\text { recruitment fee. Compensation } \\
\text { should be based on sales to end } \\
\text { consumers. }\end{array}$ & Considered illegal \\
\hline $\begin{array}{l}\text { Number of levels allowed in an } \\
\text { MLM scheme }\end{array}$ & Limited for sake of transparency & $\begin{array}{l}\text { Unlimited, number of levels not in } \\
\text { correlation with legality }\end{array}$ \\
\hline Exit conditions & Buy-back policy & $\begin{array}{l}\text { Buy-back policy and cooling-off } \\
\text { period offered to distributors by } \\
\text { industry Codes }\end{array}$ \\
\hline Internal consumption & $\begin{array}{l}\text { Prohibited as it creates profit within } \\
\text { the system, sales to be made to final } \\
\text { consumers }\end{array}$ & APermitted to a "limited" extent \\
\hline Chain letter systems/Referral sales & $\begin{array}{l}\text { Chain-letter systems should be } \\
\text { outlawed only in the case when the } \\
\text { investment and therefore the poten- } \\
\text { tial loss is considerable as is the case } \\
\text { in pyramid- and snowball systems. }\end{array}$ & $\begin{array}{l}\text { Referral scheme is illegal if it is } \\
\text { dependent upon an event subse- } \\
\text { quently occurring (which may or } \\
\text { may not happen). }\end{array}$ \\
\hline
\end{tabular}

${ }^{472}$ Babener, J. A, MLMLegal.com., 'The Landmark Amway Case', 1999, http://www.mlmlegal.com/landmark. html (last visited 17 September 2014) 


\subsection{Evaluation}

\subsubsection{Interpretation of the Legislative Output}

Adopted as originally proposed by the Commission in 2003, the current wording of the pyramid promotional schemes, as enshrined in Item 14, Annex I of the UCPD is as follows:

'Establishing, operating or promoting a pyramid promotional scheme where a consumer gives consideration for the opportunity to receive compensation that is derived primarily from the introduction of other consumers into the scheme rather than from the sale or consumption of products.'

One will immediately notice that the actual definition that has been adopted is very similar to that proposed by FEDSA; a closer look at the scope and the interpretation of the definition's various elements will, however, reveal the following, major differences.

Concerning the scope of application, the keen observer will realise that the definition proposed by FEDSA has been narrowed down, as the subject of the FEDSA definition "participant" has been replaced by the term "consumer" in the Directive. The reason for the replacement of the term was most probably that the term "participant" is alien to European law on the one hand and that the purpose of the UCPD is consumer protection and is therefore limited to $\mathrm{B} 2 \mathrm{C}$ transactions, for which reason the pyramid scheme definition has also been tailored to $\mathrm{B} 2 \mathrm{C}$ transactions.

And what a difference one word makes. Under the respective provisions of the UCPD, and in line with other consumer legislation, "consumer" means 'any natural person who, in commercial practices covered by the Directive, is acting for purposes which are outside his trade, business, craft or profession. ${ }^{373}$ For a more comprehensive picture, it is important to look at the European Court of Justice's interpretation of the term "consumer" and "consumer contracts" in its case law in more detail. As will be demonstrated below, the Court applies a strict interpretation of these terms. ${ }^{474}$

In Societe Bertrand v. Paul Ott KG $\mathrm{K}^{475}$ in a dispute that arose between two commercial parties concerning the sale of a machine on instalment credit terms, the Court gave a restrictive interpretation of the notion of consumers. The Court held that a restrictive

\footnotetext{
${ }^{473}$ Article 2 lit. a) Directive 2005/29/EC

${ }^{474}$ The analysis of relevant case law is based upon the guidance of my esteemed colleague, Jens Karsten, LL.M., former Legal Adviser of FEDSA and Dobson, P., 'Does the ban on pyramid promotional schemes challenge the business model of a typical direct selling company?' In 2 Journal of Business Law 2011, p. 194-207.

${ }^{475}$ Case C-150/77 Societe Bertrand v. Paul Ott KG [1978] ECR 1431
} 
interpretation entails the restriction of the jurisdictional advantage described above to buyers who are in need of protection, their economic position being one of weakness in comparison with sellers by reason of the fact that they are private final consumers and are not engaged, when buying the product acquired on instalment credit terms, in trade or professional activities. ${ }^{476}$

Similarly, in Benincasa v. Dentalkit, ${ }^{477}$ where the CJEU was asked to give a preliminary ruling on the interpretation of the concept of "consumer" under the 1968 Brussels Convention- the Court construed the notion of "consumer" strictly. The question of the referring court was whether a plaintiff is to be regarded as a consumer within the meaning of the Convention ${ }^{478}$ even if his action relates to a contract which he concluded not for the purpose of a trade which he was already pursuing but a trade to be taken up only at a future date. In this case, the "trade" referred to is a franchising agreement concluded for the purpose of setting up a business. In the context of the specific regime established by Article 13 et seq. of the 1968 Brussels Convention (Article 15 et seq. of the Brussels I Regulation), only contracts concluded for the purpose of satisfying an individual's own needs in terms of private consumption come under the provisions designed to protect the consumer as the party deemed to be the weaker party economically. On the other hand, the specific protection sought to be afforded by those provisions is unwarranted in the case of contracts for the purpose of trade or professional activity, even if that activity is only planned for the future, since the fact that an activity will happen in the future does not divest it in any way of its trade or professional character. It follows that the regime in question applies solely to contracts concluded outside and independently of any trade or professional activity or purpose, whether present or future, so that a plaintiff who has concluded a contract with a view to pursuing a trade or profession, not at the present time but in the future, may not be regarded as a consumer within the meaning of paragraph 1, point 1 of Article 13 and the first paragraph of Article 14 of the Convention (Article 15(1), point 1, and Article 16(1) of the Brussels I Regulation). ${ }^{49}$

In Johann Gruber v Bay Wa $A G^{480}$ the Court had to answer the question whether Section 4 of the Brussels Convention covers contracts for goods intended for purposes which are in part within and in part outside a person's trade or profession. The case concerns an Austrian farmer who purchased tiles from a German trader in order to

\footnotetext{
${ }^{476}$ Ibid. para. 21.

${ }^{477}$ Case C-269/95 Francesco Benincasa v Dentalkit Srl. [1997] ECR I-3767

${ }^{478}$ First paragraph of Article 13 and the first paragraph of Article 14 of the Convention [Article 15(1), point 1], and Article 16(1) of the Brussels I Regulation (Council Regulation (EC) No 44/2001 of 22 December 2000 on jurisdiction and the recognition and enforcement of judgments in civil and commercial matters)

${ }^{479}$ Case C-269/95 Francesco Benincasa v Dentalkit Srl., para. 3.

${ }^{480}$ Case C-464/01 Johann Gruber v Bay Way AG [2005] ECR I-439
} 
replace the roof of his farm building. In the course of the negotiations, the farmer told the German trader that the tiles were meant to replace the roof of the farm building and some ancillary buildings but, however, failed to expressly inform the latter whether the reparation would serve private or business purposes. Subsequent to the delivery, the Austrian farmer noticed that the tiles were defective and initiated proceedings under Article 13 (1) of the Brussels Convention (Article 16 (1) of the Brussels I Regulation). The CJEU concluded that a person may not rely on the special rules of jurisdiction laid down in Articles 13 to 15 of the 1968 Brussels Convention (Articles 15 - 17 of the Brussels I Regulation) unless the trade or professional purpose is so limited as to be negligible in the overall context of the supply, the fact that the private element is predominant being irrelevant in that respect. ${ }^{481}$

In a case concerning direct selling, the European Court of Justice has again given a narrow interpretation of the notion of consumer under Directive 85/577. In Di Pinto ${ }^{482}$ the CJEU ruled that traders are not to be regarded as consumers covered by the Directive $85 / 577$ to protect the consumer in respect of contracts negotiated away from business premises ${ }^{483}$ The case concerned a trader that was canvassed with a view to the conclusion of an advertising contract concerning the sale of his business by representatives of Mr. Di Pinto's company, GI Commerce, and subsequently intended to renounce the effects of his undertaking within a period of seven days, as provided by the French "Law on canvassing" ${ }^{484}$ based on the Doorstep Selling Directive. The Court favoured the application of the directive in such a case and objected that a trader, when canvassed in connection with the sale of his business, finds himself in an unprepared state similar to that of an ordinary consumer. For that reason, it argued, traders also ought to be entitled to the protection which the directive confers. ${ }^{485}$ However, the Court rejected this argument, stating that 'There is every reason to believe that a normally well-informed trader is aware of the value of his business and that of every measure required by its sale, with the result that, if he enters into an undertaking, it cannot be through lack of forethought and solely under the influence of surprise.' ${ }^{486}$

In light of the foregoing, it is clear that the CJEU interprets the notion of "consumer" narrowly and consistently refuses to grant businesses - no matter how small they may be- the same scope of protection as to consumers. As a result, only the most primitive

\footnotetext{
${ }^{481}$ Ibid., para. 39.

${ }^{482}$ Case C-361/89 - Criminal proceedings v Patrice Di Pinto [1991] ECR I-01189

${ }^{483}$ Ibid., para. 19.

${ }^{484}$ Law No 72-1137 of 22 December 1972 on the protection of consumers regarding canvassing and door-todoor selling (Official Gazette of the French Republic of 23 December 1972)

${ }^{485}$ Case C-361/89 - Criminal proceedings v Patrice Di Pinto [1991] ECR I-01189, para. 17.

${ }^{486}$ Ibid., para. 18.
} 
forms of pyramids are caught by Item 14 - frauds that are a touch more sophisticated and are disguised as MLMs are by nature and per definition excluded from the scope of protection granted by European law.

The interpretation of several other elements - such as the notion of "consideration" or, more importantly, the term "primarily"- of the definition in Item 14 were been left unclear until the European Court of Justice gave some guidance on the interpretation in 2014 in a Lithuanian court's request for preliminary ruling on Item 14, although not on all problematic issues.

The Court ruled that the prohibition of pyramid promotional schemes is based on three common conditions:

'First, such a promotion is based on the promise that the consumer will have the opportunity of making a commercial profit. Next, the realisation of that promise depends on the introduction of other consumers into the scheme. Finally, the greater part of the revenue to fund the compensation promised to consumers does not result from a real economic activity.' ${ }^{487}$

The Court focused on the unsustainable geometric progression of a scheme, i.e. a "scheme can only be a "pyramid" in the sense that its sustainability requires the subscription of an ever increasing number of new participants to fund the compensation paid to existing members. It also means that the most recent members are less likely to receive compensation for their participation. That scheme ceases to be viable when the growth in membership, which should theoretically tend to infinity in order for the scheme to continue, is no longer sufficient to fund the compensation promised to all participants.' ${ }^{488}$

The Court has established three requirements for a scheme to be qualified as a pyramid in all cases. Firstly, the recognition of a pyramid scheme requires its members to give a financial consideration, regardless of its amount. ${ }^{489}$ Secondly, in order for a scheme to be classified as a pyramid within the meaning of Item 14, the existence of a link between the consideration given by new members and the compensation received by existing members is necessary. ${ }^{490}$ Thirdly, 'the funding of the compensation that a consumer may receive depends "primarily" or "mostly" on the consideration given

\footnotetext{
${ }^{487}$ Case C-515/12 4finance UAB v Valstybine vartotoju teisių apsaugos tarnyba and another [2014] WLR (D) 156, para. 20 .

${ }^{488}$ Case C-515/12 4finance UAB v Valstybine vartotoju teisiu apsaugos tarnyba and another [2014] WLR (D) 156 , para. 22.

${ }^{489}$ Ibid., para. 23-26.

${ }^{490}$ Ibid., para. 27.
} 
subsequently by new participants in the scheme. ${ }^{491}$ In other words, the existence of any recruitment or headhunting fee, regardless of the amount and the fact that the compensation derives mainly from recruitment qualifies a scheme as a pyramid. The terms "primarily" and "mostly" have not been defined by the CJEU however - perhaps due to the Court's reluctance. Hence, the pyramid scheme definition is clearer - but by no means absolutely clear, with one of its key problem-terms left unexplained.

While it appears that the aforementioned three conditions are subject to strict interpretation which Member States may not diverge from, the Court offered some leverage for Member States' courts in stating that while the Blacklist entails the most harmful practices that are prohibited in all circumstances, other detrimental practices may also be prohibited upon examination on a case-by-case basis under Articles 5-9 of the UCPD. ${ }^{492}$ It remains to be seen how national courts will utilise this new opportunity to counter illegal practices: while this specific part of the judgment may work against the uniform interpretation of EU law, it may open a window of opportunity for national courts to fill in the remaining gaps of statutory law.

\subsubsection{Evaluation}

The purpose of the present chapter devoted to the assessment of the lobbying dossier concerning the pyramid scheme regulation is to explore the aims of the advocacy goals of the direct selling industry in regards to the shaping of this particular field of unfair competition law and to examine the extent to which the industry was successful in influencing the European legislator.

In search for the answer to the research question, the direct selling industry's position concerning the pyramid scheme regulation and the possible regulation of MLMs was described in the context of another regulatory concept put forward by VIEW.

The analysis of the industry's position has revealed that the preferred pyramid scheme definition was based on US federal law and was more generic in nature, whereas the definition of the VIEW Report was wider in its scope and more specific.

As described in the previous sections, the direct selling industry and its well-founded argumentation was largely accepted by the EU legislator, possibly also due to the intellectual comfort demonstrated by the industry's technical expertise and the reference to the already existing and tried US model provided, rendering the present pyramid scheme definition one of the greatest successes of the industry advocacy. Furthermore, the US trend of deregulating MLMs has also been followed by the European legislator.

\footnotetext{
${ }^{491}$ Ibid., para. 28.

${ }^{492}$ Ibid., para. 32 .
} 
While the deregulation of MLM schemes in itself is not necessarily a negative development, the pyramid scheme definition in its current form is incomplete. The lopsidedness of the norm is to be examined from two perspectives: its scope and its generic nature.

Firstly, because the European legislator has decided to restrict the scope of the definition to B2C schemes by replacing the term "participant" as originally proposed by the industry (based on US federal law) with the term "consumer" -casually ignoring the red flags waived by the VIEW Report- the measure's teeth have largely been taken out. While the current definition does offer protection to defrauded consumers, as indicated earlier, the vast majority of pyramid schemes are usually disguised as legitimate MLMs wherefore pyramids tend to operate based on B2B relations - however, this latter territory was left uncovered by European private law.

Secondly, the present pyramid scheme definition is rather generic, lacking tight rules on the specificities of pyramid schemes. As the circumspect reader will remember, in the introduction to the current chapter, it was indicated that there is a very fine line between legitimate MLMs and pyramid schemes and the grey area between legitimate MLMs and pyramid schemes can only be minimised through a tight system of control. The ambiguity of blanket provisions allows fraudulent schemes to proliferate, causing a morality deficit for the entire industry. ${ }^{493}$

Compared to the US regulatory model, the European pyramid scheme definition's scope is narrower than that of US federal law, and, taken out of its original context of US case law, the norm does not offer protection to small businesses in the realm of European unfair competition law, although it is precisely the SMEs and micro-enterprises that are prone to be defrauded by scams that camouflage themselves as legitimate MLMs. The current regulation only protects consumers who become participants of illegally operating schemes, although it is only the most primitive scams that operate on a $\mathrm{B} 2 \mathrm{C}$ basis - the more sophisticated scams are disguised as multi-level marketing companies and operate through $\mathrm{B} 2 \mathrm{~B}$ transactions.

Although the CJEU has made some clarifications and specifications of the provision at hand, what remains absent is the introduction of certain safeguards and the regulation of internal consumption and snowball systems, namely:

1. First and foremost, the extension of the pyramid scheme definition to B2B schemes to catch pyramids that masquerade themselves as legitimate MLMs.

\footnotetext{
493 Thompson, K., 'Pyramid Schemes: Saving the network marketing industry by defining the gray', Scribd, (July 2009), p.15., http://www.scribd.com/doc/13639323/Pyramid-Schemes-Saving-the-network-marketingindustry-by-defining-the-gray (last visited 17 September 2014)
} 
2. The prohibition of large entry fees and inventory loading.

3. The introduction of a mandatory buy-back policy (a guarantee to refund at least $90 \%$ of net cost of inventory and sales aids purchased 12 months prior to the time the salesperson wishes to leave the scheme) to eliminate the possibility of inventory loading.

4. The explicit regulation and prohibition of exaggerated and unsubstantiated earnings claims and deceptive earnings representations.

5. The regulation of internal consumption by putting guarantees in place that require customer sales, as the present pyramid scheme definition does not disallow the notion of internal consumption. In other words, the current definition allows an entity to legally function without making any retail sales to consumers.

In the United States, the issue of internal consumption has been subject to considerable debate for decades: case law ${ }^{494}$ in Koscot, Amway and Webster $v$. Omninitrition International Inc. has taken a restrictive standpoint in this respect: in its ruling in Webster v. Omninitrition International Inc., ${ }^{495}$ the court ruled that for purposes of pyramid analysis, 'sale of products to ultimate users means the sale of product to those outside the organisation'. The Federal Trade Commission has been very consistent in concluding that the 'sale of products or services to ultimate users' does not include sales to other participants or recruits in the multi-level marketing program or to participants' own accounts. 496 "Ultimate users" were thus considered to be consumers strictly outside the respective MLM marketing model.

As a safeguard, following the Amway case, many US direct selling companies have voluntarily adopted a minimum customer rule - a policy that prescribed that in order to receive compensation a certain number of sales to customers had to be demonstrated in any month as a helpful indication that the scheme was not a pyramid (e.g. "The 70\% rule": in order to be eligible for receiving commission, every distributor must sell at wholesale and/or retail at least $70 \%$ of the inventory he bought during a given month).

\footnotetext{
${ }^{494}$ In re Koscot Interplanetary, Inc., 86 F.T.C. 1106 (1975) (FTC decision), In the Matter of Amway (93 F.T.C. 618) (1979), Webster v. Omnitrition International, 79 F.3d 776 (1996)

${ }^{495}$ Webster v. Omninutrition International Inc. (1996), 79 F.3d 776, 781-782 (9th Cir.), cert. denied, 117 S Ct. 174 U.S. (No. 94-16477).

496 Amquix, Amquix.info, 'Amquix explains pyramid schemes' http://www.amquix.info/quixtar_pyramid_ rebuttal.html (last visited 17 September 2014)
} 
As an interesting development, and for the industry clearly a step in the right direction in that it narrows the grey area, the recent BurnLounge decision ${ }^{497}$ of June 2014 ruled that 'the participants were the "ultimate users" of the merchandise and that this internal sale alone does not make BurnLounge a pyramid scheme'. ${ }^{498}$ Evidently, there appears to have been a shift in US case law concerning the notion of internal consumption and whether it renders a business structure a pyramid scheme. ${ }^{499}$

In Europe, the issue of internal consumption has gained less attention from a legislative or judicial perspective than in the US, and academic literature is also scarce on the matter. Noted legal expert of direct selling Paul Dobson argues against the possibility of distributors to receive commission derived from their personal consumption and calls it an 'impossible stretch of the imagination' that an MLM company would compensate the distributor for consuming their products and rejects this possibility. ${ }^{500}$ On the other hand, as UK DSA Director General Paul Southworth has put it, 'The reality is that it is virtually impossible for companies to actually know which products purchased are for personal use versus for onward sales. It would always be a pure estimate and the volume and percentage would vary with each order placed. With this in mind, therefore, a company's systems for up and down line compensation payments can only operate on the total value and therefore payments have to be made accordingly. Change to this can only come if a company is able to accurately segment their sales force between buyers and sellers. ${ }^{501}$

In an effort to both ensure the legality of a scheme and to remain realistic about the fact that direct sellers do purchase products for their personal consumption, the introduction of a certain percentage (e.g. 70\%) requirement of customer sales could be a compromise.

6. The definition and prohibition of referral sales by European law.

\footnotetext{
${ }^{497}$ FTC v. BurnLounge, U.S. Court of Appeals, Ninth Circuit (2014)

${ }^{498}$ FTC v. BurnLounge, U.S. Court of Appeals, Ninth Circuit (2014) Decision p. 19.

499 Thompson, K., Direct Selling News Blog, 'The BurnLounge Court Decision Clears the Air on Many Issues', 5 August 2014, http://dsnblog.com/tag/pyramid-scheme/ (last visited 17 September 2014) and Babener, J. A., MLMLegal.com, 'BurnLounge Appeal Decision:

Guidance on Pyramid v. Legitimate MLM and the Role of Personal Use in Pyramid Analysis', 2014, http://mlmlegal.com/Burnlounge\%20Appeal.html (last visited 17 September 2014)

${ }^{500}$ Dobson, P., 2 Journal of Business Law (2011), p. 200.

${ }^{501}$ Ozmorali, H., The World of Direct Selling, 'Wisdom in 100 Words: Personal Consumption' , 9 June 2014, http://www.worldofdirectselling.com/100-words-personal-consumption/ (last visited 17 September 2014)
} 
As for the status quo, not surprisingly, the majority of the industry is in favour of the present definition and has been successfully lobbying for the maintenance thereof so far. In its first report ${ }^{502}$ of March 2013 on the application of the UCPD, the Commission namely concluded that there was no need to further harmonise pyramid promotional schemes at the time and referred to the opinions submitted by Seldia and Direct Selling Europe as well as the fact that no objections have been raised by consumer organisations or other stakeholders concerning Item 14 .

Seldia considered the current legislation adequate and claimed that the definition proved to be largely beneficial, enabling them to set up one single business model which could be valid across the EU, in a sort of "one-stop shop" fashion. DSE - the competing direct selling trade association - has taken a similar position and considered the existing legal framework complete. ${ }^{503}$

There was only one respondent, "a company active in direct selling", that suggested in its contacts with the Commission services that, in the context of pyramid schemes, there should not be any distinction between consumers and professionals and that Member States should be encouraged to apply the national laws transposing Annex I (Item 14) of the UCPD mutatis mutandis to business-to-business pyramid promotional schemes. ${ }^{504}$ While fully supporting the point the company raised, one cannot help but wonder whether the company at hand is truly concerned about the quality of European private law and the moral state of the industry and/or it is perhaps a company that does not operate an MLM system and would therefore like to gain competitive advantage through advocating legislation that is more restrictive for MLMs. While one can only speculate about the identity and intentions of this company active in direct selling, it is certain that MLMs' holy war to maintain the status quo is not only fought against legislators and consumer movements but in fact also against their competitors within the direct selling industry. This lack of unanimity within the industry is likely to weaken the chances of MLMs to defend their position in the long run.

Secondly, although the Commission report claims that consumer organisations have not raised concerns in relation to Item 14 per se in the course of the public consultation

\footnotetext{
502 European Commission, First Report on the application of Directive 2005/29/EC of the European Parliament and

of the Council of 11 May 2005 concerning unfair business-to-consumer commercial practices in the internal market and amending Council Directive 84/450/EEC, Directives 97/7/EC, 98/27/EC and 2002/65/EC of the European Parliament and of the Council and Regulation (EC) No 2006/2004 of the European Parliament and of the Council

('Unfair Commercial Practices Directive') Brussels, 14 March 2013, COM(2013) 139 final.

${ }^{503}$ Ibid., p. 19-20.

${ }^{504}$ Ibid., p. 19-20.
} 
held in 2011, in its response to the Commission's questionnaire in 2011 BEUC did suggest that the scope of application of the UCPD be extended to mixed purpose contracts. $^{505}$ Logically, this would mean that the scope of application of the pyramid schemes should also be extended to mixed purpose contracts which currently -thanks to the CJEU's ruling in Gruber- is clearly not the case. The second time around, in the position on the Commission's report on the UCPD, BEUC voiced a more nuanced opinion: it pinpointed to the definition of pyramid promotional schemes specifically in that it presents difficulties in relation to the reference to consumers giving 'consideration for the opportunity to receive compensation' and the definition of consumer under Art. 2(a). BEUC rightly notes that under the current definition of the term "consumer", 'individuals with a commercial interest' (as BEUC puts it) are generally the victims of such an unfair practice. BEUC thus suggests that 'the protection intended to consumers could be twisted by a formalistic interpretation of this provision vis-à-vis the restrictive definition of consumer of the Directive. ${ }^{506}$

All in all, the current wording of the pyramid scheme definition is partly the result of the direct selling industry's successful lobbying efforts and as such, is a great achievement for the industry - if not the greatest - for the industry advocacy. But fundamental flaws of the current regulation should no longer go unnoticed. While the industry will presumably continue its campaign to maintain the current wording, more and more stakeholders both from within as well as from outside the industry are joining calls from academia for the revision of the pyramid scheme definition.

Recommendations would therefore be, firstly, to extend the scope of the pyramid scheme definition to schemes based on B2B transactions and, secondly, to build the safeguards into the revised definition or its guidelines that have been developed by US case law: the prohibition of high entry fees and inventory loading, the provision of a buy-back policy, the express disallowance of deceptive earnings claims, the establishment of a minimum customer rule as qualification for eligibility to receive commissions and bonuses on sales/purchases made by other representatives in their personal sales organisation and the regulation referral sales.

\footnotetext{
505 Unfair Commercial Practices - European Commission's questionnaire on the application of Directive 2005/29/EC - BEUC's response; Ref.: X/2011/109 - 26 October 2011; p.11., http://www.beuc.org/ publications/2011-09895-01-e.pdf (last visited 17 September 2014)

506 European Commission's report on the application of the Unfair Commercial Practices Directive - BEUC position paper; Ref.: X/2013/049 - 24 June 2013, p. 8., http://www.beuc.org/publications/2013-00457-01-e.pdf (last visited 17 September 2014)
} 


\subsection{Conclusion}

Regulation of new marketing techniques of the direct selling industry being of pivotal interest for the sector, the direct selling industry has made considerable lobbying efforts to achieve favourable legislation in the EU by supplying the European legislator with significant technical input. Besides the study on the comparative analysis of Member State laws that FEDSA commissioned and Amway supported, the industry lobby's global actor, the World Federation of Direct Selling Associations has also provided its professional input from the perspective of US federal and state law and the legislative trends in the United States concerning the regulation of new marketing practices within the direct selling industry.

Convinced by the extensive industry input, the European legislator has largely (and incompletely) adopted the US law-based pyramid scheme definition put forward by the industry - but without the safeguards that US case law has developed.

The result is a norm that is incomplete: the present definition is generic and ambiguous and, moreover, because its scope has been narrowed down to $\mathrm{B} 2 \mathrm{C}$ transactions only to tailor it to the scope of the UCPD, it is incapable of catching the vast majority of pyramid promotional schemes that are masqueraded as legitimate MLMs that are per definition B2B structures wherefore it does not offer protection to small businesses that could be defrauded by scammers.

While the industry's present position -both that of Seldia and DSE- is that the present pyramid scheme regulation is sufficient, this study suggests that tighter rules and specific safeguards be put in place in order to reduce the grey area in which pyramids and questionable market practices can proliferate. For that purpose, the scope of the pyramid definition should be extended to B2B schemes, high entry fees and inventory loading should be prohibited, outrageous and unsubstantiated earnings claims should be expressly outlawed, a buy-back policy and requirements of customer sales need to be put in place and referral sales should be regulated. 



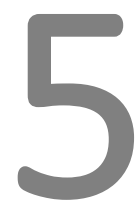

Dossier 3:

Self-Regulation 



\subsection{Introduction}

The direct selling industry is one of the few sectors that established a global voluntary normative framework governing its members' commercial conduct, demonstrating the industry's devotion to fair trading. The World Code of Ethics, ${ }^{507}$ claims the industry, is the 'cornerstone of the direct selling industry's commitment to ethical business practices and customer service. It is a mechanism that ensures that independent salespeople and customers are treated fairly and respectfully. ${ }^{508}$ Correspondingly, the European Codes of Conduct ${ }^{509}$-as part of a world-wide private regulatory scheme- express a strong determination to set the highest ethical standards for the industry and ensure compliance thereto.

While globalisation has undoubtedly incentivised a general trend of multinational companies' participation in collective efforts to increase international standards that go beyond what is required by national legal regimes, ${ }^{510}$ one may still be left wondering about the specific motives behind an industry's aspiration to regulate itself and how selfregulation may contribute to an industry's advocacy efforts specifically. The present chapter will thus aim to look at the direct selling industry's European Codes in detail and will subsequently look at the industry's motivations and morality issues behind its grand self-regulatory efforts. Moreover, from the perspective of the industry Codes' contribution to EU law the direct selling industry self-regulation will be examined as an agent of European harmonisation.

\subsection{European Codes of Conduct for Direct Selling}

Seldia and Direct Selling Europe use voluntary codes of conduct: Seldia (earlier FEDSA) adopted its codes in 1995, whereas DSE set down its own system of private norms at the time of its foundation.

\footnotetext{
${ }^{507}$ The World Code of Ethics can be found at the WFDSA website at http://www.wfdsa.org/files/worldcodes/code-book.pdf (last visited 17 September 2014)

${ }^{508}$ Overview of the WFDSA Code of Ethics, available at http://www.wfdsa.org/world_codes/about-the-code/ (last visited 17 September 2014)

509 Seldia's European Codes of Conduct are available on the Seldia website at http://www.seldia.eu/images/pdf/SELDIA3993_CodeofConduct_02.pdf (last visited 17 September 2014)

whereas DSE's Codes are featured on the DSE website at http://www.directsellingeurope.eu/ sites/default/files/DSE_Code_of_Ethics.pdf (last visited 17 September 2014)

${ }^{510}$ Haufler, V., A Public Role for the Private Sector: Industry Self-Regulation in a Global Economy (Carnegie Endowement for International Peace, Washington D.C., 2001), p. 2.
} 
The national direct selling associations that are members to either DSE or Seldia have to adopt their national Codes of conduct that incorporate the substance of the respective European Codes, whereas corporate members have to abide by the rules enshrined therein as a condition of admission and continuation of membership. Corporate members' direct sellers are bound by the European Codes indirectly, through corporate members' required compliance.

The current section will introduce the European Codes of conduct briefly: the first sub-section deals with Codes of Conduct towards consumers, the second is devoted to the Codes of Conduct towards direct sellers and companies, whereas the third subsection assesses the enforcement of the private norms. Due to the close similitude of the two trade associations' Codes, they will not be assessed individually, unless respective provisions on certain issues differ.

\subsubsection{Codes of Conduct Towards Consumers}

The aim of the Codes of Conduct towards consumers is to set a high level of fair trading standards in order to achieve consumers' satisfaction and protection in off-premises transactions.

Specific provisions of the Codes of Conduct towards consumers govern the main elements of $\mathrm{B} 2 \mathrm{C}$ transactions in an off-premises context.

In terms of consumer contracts, the Codes prescribe detailed pre-contractual information disclosure obligations, which are more detailed than those in the Doorstep Selling Directive were, but are now more of a mere restatement of the Consumer Rights Directive's provisions. Consumers are entitled to a written confirmation of their order, a timely performance of the contracts (which, in Seldia's case is 30 days) and the right to withdraw. Seldia allows DSAs and companies to provide longer periods of withdrawal to consumers, whereas DSE specifies that consumers are entitled to withdraw from contracts even in the event that the contract falls under the low threshold value exemption.

Looking at the terrain of commercial practices, the Codes prescribe fair treatment of consumers, particularly those more vulnerable, and the respect of privacy. In line with the Unfair Commercial Practices Directive, commercial communication directed at consumers -be it verbal promises or statements, testimonials, or any other literaturemust be truthful and authorised by the direct selling company.

Lastly, as an element supplementary to EU law, the notion of referral sales -schemes that are based upon the representation made to consumers that a consumer may reduce or recover the purchase price by referring other consumers to the sellers for similar 
purchases- is outlawed by both Codes, although Seldia prohibits it only in the event that reductions or recovery are contingent upon some unsure future event. ${ }^{511}$

The charts below compare provisions of the two Codes (that of Seldia and DSE) to the relevant provisions of existing European law and directives, the CRD and the UCPD. A higher level of protection is granted by the Codes in terms of the withdrawal right, the length of which is undefined and whereby members may adopt longer cooling-off periods, the express prescription of fair treatment of vulnerable consumers, the respect of consumers' privacy and, very importantly, the prohibition of referral sales which is completely missing from European law.

\begin{tabular}{|c|c|c|}
\hline Subject matter & Seldia code (B2C) & EU legislation \\
\hline \multirow{7}{*}{$\begin{array}{l}\text { Commercial } \\
\text { communication }\end{array}$} & Art. 2.1 Prohibited practices & UCPD Art. 5 \\
\hline & Art. 2.3 Accurate answers to questions & UCPD Art. 5 \\
\hline & $\begin{array}{l}\text { Art. } 2.5 \text { Verbal promises authorised by } \\
\text { company }\end{array}$ & \\
\hline & Art. 2.8 Literature & UCPD Art. 5 and Directive 2010/13/EU \\
\hline & & Rec. (47), (60), (61) \\
\hline & Art. 2.9 Testimonials & UCPD Art. 5 \\
\hline & Art.2.10 Comparison and denigration & MCAD Art. 4 \\
\hline \multirow{9}{*}{$\begin{array}{l}\text { Pre-contractual } \\
\text { information }\end{array}$} & Art.2.2. & CRD Art. 6(1) \\
\hline & - product characteristics & Art. 6(1) lit. a) \\
\hline & - identity and address of trader & Art. 6(1) lit. b) and c) \\
\hline & - price & Art. 6(1) lit. e) \\
\hline & - delivery costs & Art. 6(1) lit. e) \\
\hline & - terms of payment & Art. 6(1) lit. g) \\
\hline & - withdrawal right & Art. 6(1) lit. h) \\
\hline & - guarantee & Art. 6(1) lit. 1) \\
\hline & - after-sales service & Art. 6(1) lit. e) \\
\hline Respect of privacy & $\begin{array}{l}\text { Art. } 2.11 \text { - contact to be made in } \\
\text { reasonable manner at reasonable hours }\end{array}$ & UCPD Annex I item 25 and 26 \\
\hline Fairness & $\begin{array}{l}\text { Art. } 2.12 \text { - Protection of vulnerable } \\
\text { consumers }\end{array}$ & UCPD Rec.(18) and Art.5(3) \\
\hline $\begin{array}{l}\text { Written confirmation } \\
\text { of information }\end{array}$ & Art. 2.7 Order form & CRD Art. $7(1)$ \\
\hline Withdrawal right & $\begin{array}{l}\text { Art. } 2.6 \text { - length at least the one provided } \\
\text { by law; time of commencement not } \\
\text { specified }\end{array}$ & $\begin{array}{l}\text { CRD Art. } 9 \text { - } 14 \text { days, time of } \\
\text { commencement: services: conclusion of } \\
\text { contract/goods: delivery of product }\end{array}$ \\
\hline
\end{tabular}

${ }^{511}$ Seldia Code Art.2(13) and DSE Code Chapter II Art.13 


\begin{tabular}{|c|c|c|}
\hline Subject matter & Seldia code (B2C) & EU legislation \\
\hline Referral sales & $\begin{array}{l}\text { Art. } 2.13 \text { - prohibition of referrals sales if } \\
\text { reductions or recovery are contingent } \\
\text { upon some unsure future event. }\end{array}$ & \\
\hline Performance & Art. 2.14 - within 30 days & CRD Art. 18 - delivery within 30 days \\
\hline Enforcement & $\begin{array}{l}\text { Art. } 3 \text { - Complaints and Code } \\
\text { administrator }\end{array}$ & $\begin{array}{l}\text { CRD Art. } 23 \text { - Art.23(2) lit. c) - professional } \\
\text { organisations having a legitimate interest in } \\
\text { acting may be included }\end{array}$ \\
\hline \multirow[t]{3}{*}{$\begin{array}{l}\text { Commercial } \\
\text { communication }\end{array}$} & $\begin{array}{l}\text { Chapter II Art. } 4 \text { Verbal promises } \\
\text { authorised by company }\end{array}$ & $\begin{array}{l}\text { Chapter II Art. } 4 \text { Verbal promises } \\
\text { authorised by company }\end{array}$ \\
\hline & Chapter II Art.12 Literature & Chapter II Art.12 Literature \\
\hline & Chapter II Art. 6 Testimonials & Chapter II Art. 6 Testimonials \\
\hline \multirow{9}{*}{$\begin{array}{l}\text { Pre-contractual } \\
\text { information }\end{array}$} & Chapter II Art. 2 and 3 & CRD Art. 6(1) \\
\hline & - product characteristics & Art. 6(1) lit. a) \\
\hline & - identity and address of trader & Art. 6(1) lit. b) and c) \\
\hline & - price & Art. 6(1) lit. e) \\
\hline & - delivery costs & Art. 6(1) lit. e) \\
\hline & - terms of payment & Art. 6(1) lit. g) \\
\hline & - withdrawal right & Art. 6(1) lit. h) \\
\hline & - guarantee & Art. 6(1) lit. 1) \\
\hline & - after-sales service & Art. 6(1) lit. e) \\
\hline \multirow[t]{4}{*}{ Fair conduct } & Chapter II Art. 1 & \\
\hline & - respect of privacy & UCPD Annex I item 25 and 26 \\
\hline & - protection of vulnerable consumers & UCPD Rec.(18) and Art.5(3) \\
\hline & - prohibition of misleading claims & UCPD Art. 5 \\
\hline $\begin{array}{l}\text { Written confirmation } \\
\text { of information }\end{array}$ & Chapter II Art. 5 Order form & CRD Art. 7(1) \\
\hline Withdrawal right & $\begin{array}{l}\text { Chapter II Art. } 7 \text { - length and } \\
\text { commencement not specified but right } \\
\text { of withdrawal granted even if payment is } \\
\text { below the legal threshold provided by } \\
\text { national law }\end{array}$ & $\begin{array}{l}\text { CRD Art. } 9 \text { - } 14 \text { days, time of } \\
\text { commencement: services: conclusion of } \\
\text { contract/goods: delivery of product }\end{array}$ \\
\hline Referral sales & $\begin{array}{l}\text { Chapter II Art.13 - prohibition of referral } \\
\text { sales }\end{array}$ & \\
\hline \multirow[t]{2}{*}{ Performance } & $\begin{array}{l}\text { Chapter II Art. } 9 \text { - performance in a } \\
\text { timely manner; }\end{array}$ & CRD Art. 18 - delivery within 30 days \\
\hline & Art. 10 - after sales service and guarantees & \\
\hline Enforcement & $\begin{array}{l}\text { Chapter V - no Code administrator or } \\
\text { ADR body established }\end{array}$ & CRD Art. 23 \\
\hline
\end{tabular}




\subsubsection{Codes of Conduct Towards Direct Sellers and Companies}

A territory of key importance, the main rules governing conduct towards direct sellers have been codified by both Seldia and DSE based on the industry standards set by the Direct Selling Association of the United States and WFDSA in 1993.

Measures of the Codes of Conduct towards direct sellers are concentrated on the most problematic area, namely the pyramid promotional schemes, but entail provisions concerning education and training to aid distributors' operation and ethical trading as well.

In terms of the private regulation of pyramid schemes, there are six specific measures or safeguards to assess that are all complementary to European unfair competition law.

Firstly, false earnings claims being an indication that a scheme may be a pyramid, misleading and deceptive statements in the course of the recruitment procedure are expressly prohibited by Seldia's Code (Article B.b) as a substantiation and interpretation of the UCPD's (in B2C transactions) and MCAD's (in B2B transactions) general prohibition of misleading claims; stipulating that 'Companies and direct sellers shall not misrepresent the actual and potential sales or earnings of their direct sellers. Any earnings or sales representations made shall be based upon documented facts and shall not only refer to isolated successes' (Article B.d) in an attempt to achieve increased transparency. This provision appears to have been founded upon the US Federal Trade Commission's practice which considers every earnings claim a "deceptive trade practice" unless it is accompanied by a simultaneous disclosure of distributors' average earnings and the percentage of distributors who achieve various earning levels. ${ }^{512}$

DSE's Code stipulates that direct sellers shall be recruited solely in accordance with generally recognised principles of fair competition (Chapter III Article 2).

Secondly, the Seldia Code prohibits companies to require direct sellers or prospective direct sellers to pay unreasonably high entry fees ${ }^{513}$ while DSE excludes entry fees per $s e^{514}$ as many pyramid schemes tend to demand high entry fees from the participants, although the mandatory purchase of a starter kit is possible, so long as the purchaser receives reasonable market value for the items and services purchased. European law also lacks this safeguard.

\footnotetext{
512 Babener, J., MLMLegal.com, 'Direct Sales - An Overview - The Legal Environment', 2010, p. 18., http://www.jdsupra.com/legalnews/direct-sales-an-overview-the-legal-env-95441/ (last visited 17 September 2014)

${ }^{513}$ Article B.f. of the Seldia Code

${ }^{514}$ Chapter III Article 5 of the DSE Code
} 
Thirdly, inventory loading -obliging direct sellers to buy overstock- is prohibited by both $\operatorname{Codes}^{515}$ in order to offer protection against another hallmark of pyramid schemes, again supplementing the EU law regulating pyramids.

Fourthly, the Codes offer a buy-back policy: ${ }^{516}$ upon termination of the contract between the direct seller and the company, the company shall buy back all products purchased. The buy-back policy had only been a recommendation of the worldwide industry Codes until 1993 when it became an industry standard. The standard is rooted in the case against Amway ${ }^{517}$ (decided in 1979) in which the US Federal Trade Commission pointed to the inventory repurchase policy of the company as a strong indicator that the Amway was not a pyramid. Thereafter, recognising that no pyramid scheme would ever offer a bona fide repurchase of inventory at $90 \%$ of its original cost to the salesperson (thus effectively making departing salespeople whole and immunising them from the risk of significant loss) the industry adopted a requirement that member companies repurchase at least $90 \%$ of the original cost of all unused or undamaged inventory. ${ }^{518}$ The buy-back policy is a key safeguard against pyramid schemes, but this requirement is also an additional element missing from EU law.

Fifthly, notwithstanding the buy-back policy both Codes provide for direct sellers, Seldia provides direct sellers a period of at least seven calendar days within which to withdraw from the agreement concluded with the company without penalty and without giving any reason. Where the direct seller exercises the right of withdrawal, the company is obliged to buy back all original, new and unused products and business aids that the direct seller purchased at the start of his activities. The company shall also reimburse free of charge all sums paid by the direct seller. ${ }^{519}$ This latter provision of the Seldia Code is rather appealing for prospective direct sellers, especially in light of the fact that a similar measure (Recital 13) is featured in the Consumer Rights Directive which allows Member States to extend the scope of the Directive to small- and micro businesses. Should a Member State decide to apply the Directive to B2microB transactions, distributors will have a statutory right to withdraw from the contract within 14 days. Irrespective of whether the particular Member States decide to adopt this provision however, Seldia member companies already secure a 7-day withdrawal right to direct sellers.

\footnotetext{
${ }^{515}$ Article B.i of the Seldia Code and Chapter III Article 6 of the DSE Code.

${ }^{516}$ Article B.h of the Seldia Code and Chapter III Article 7 of the DSE Code.

${ }^{517}$ Amway Corp., 93 FTC 618 (1979)

${ }^{518}$ Mariano J. N., Brossi M., Multilevel Marketing: A Legal Primer, p. 50

${ }^{519}$ Article B.g. of the Seldia Code
} 
Sixthly, the much debated phenomenon of internal consumption -personal consumption of a direct seller serving as basis of his earnings- in case of MLM companies is regulated under the Seldia Code and is permitted by Article B.d insofar as 'purchases for personal use or consumption are made in reasonable amounts', although the term "reasonable amounts" is ambiguous, rendering the entire provision on internal consumption obscure. Interestingly, however, under the current EU law definition of pyramid schemes, internal consumption is not forbidden, so even this ambiguous rule provides a higher level of protection than European law.

Education and training to direct sellers -an important benefit the direct selling industry has to offer- is to be provided by the direct selling companies to promote the professional growth and ethical operation of distributors under Articles B.k and B.l of the Seldia Code and Chapter III Articles 10-11 of the DSE Code. The DSE Code stipulates that trainings are to be free of charge whereas Seldia's Code requires that the education be either free or available at a reasonable price.

Direct selling companies are also to provide direct sellers with periodic accounts, detailing remuneration, deliveries, cancellation and other relevant data. ${ }^{520}$

Lastly, competition between direct selling companies is regulated to the extent that the Codes prescribe fair conduct for members towards each other. Enticement of other companies' direct sellers and the denigration of other companies, its products, marketing plan or any other feature of the company is prohibited ("Seldia - Code C" and Chapter IV of the DSE Code).

\subsubsection{Private Enforcement}

As regards private enforcement, monitoring compliance, complaint handling and sanctioning violations is the task of the code owners. While substantial provisions governing conduct towards consumers, direct sellers and companies of Seldia's and DSE's Codes appeared to be almost identical, it was found that private enforcement is rather different under the two Codes.

Under both systems, primary responsibility for the observance of the Codes rests with the individual companies. However, the complaint handling and enforcement procedures are rather dissimilar.

Seldia has established an independent mechanism to settle unresolved complaints: each DSA is to appoint an independent person or body as a Code Administrator to monitor companies' observance and to handle breaches of the Code. ${ }^{521}$ Complaints

\footnotetext{
${ }^{520}$ Article B.j of the Seldia Code and Chapter III Article 9 of the DSE Code.

${ }^{521}$ Article 3.1. (in B2C relations) and Article D.c. (in B2B relations) of the Seldia Code
} 
between direct selling companies are to be handled either by the Code Administrator or an independent arbitrator. ${ }^{522}$

In addition, in April 2013, Seldia's General Assembly amended the Code of Ethics and established the European Code Administrator. In B2C disputes, the European Code Administrator towards consumers consists of a committee of three members, designated by the Board: an independent Chairman, the representative of a consumer organisation (Fédération Léo Lagrange, a French consumer protection association) and one of the members of the Seldia Ethics Committee on a case-by-case basis. Seldia's Executive Director is the secretary to the B2C European Code Administrator. ${ }^{523}$ The European Code Administrator towards consumers has been notified to the European Commission as an ADR Body by the French government.

In $\mathrm{B} 2 \mathrm{~B}$ disputes, the European Code Administrator consists of a committee of four members - three appointed by the board of Seldia, with the fourth member (also designated by the board of Seldia and acting as chairman) being independent from the sector. The Executive Director of Seldia is ex officio secretary of the Code Administrator. ${ }^{524}$

After exhaustion of all private remedies (complaint to the direct seller or the company, then to the DSA if no satisfaction), the European Code Administrator can act on complaints in the following instances:

- Receive and decide on complaints from parties (consumers, direct sellers, direct selling companies, consumer bodies etc.) from one of the EEA countries without a DSA in membership of Seldia involving a direct selling company in membership of Seldia or of a DSA in membership of Seldia;

- Receive and decide on complaints from parties related to cross-border transactions and involving a direct selling company in membership of Seldia or of a DSA in membership of Seldia from one of the EEA countries;

- Receive and decide on complaints from DSAs in membership of Seldia in one of the EEA countries involving a direct selling company in membership of Seldia and;

- Receive complaints from DSAs in membership of Seldia from one of the EEA countries involving direct selling companies in membership of WFDSA, WFDSA CEO

\footnotetext{
${ }^{522}$ Article D.f . of the Seldia Code

${ }^{523}$ Seldia Code of Ethics Corrigendum - Code of Ethics towards Consumers

${ }^{524}$ Seldia Code of Ethics Corrigendum - Code of Ethics towards Direct Sellers, between Direct Sellers and between Companies
} 
Council or of DSAs outside membership of Seldia with the aim of mediation together with such direct selling companies, WFDSA and the DSA in question. ${ }^{525}$

Although the European Code Administrator does not serve as an appeal body, its jurisdiction is expanded, offering remedy in the event that the trader and the consumer do not fall under the same jurisdiction. Thus, the establishment of the European Code Administrator is crucial in entitling the complaint handling body to handle cross-border consumer complaints and it has become a sector-specific, pan-European ADR scheme.

Actions to be determined by the Code Administrator against a company regarding complaints by consumers may include cancellation of orders, return of goods purchased, refund of payment or other appropriate actions, including warnings to direct sellers and companies, exclusion of companies from DSA membership and the publication of such actions and sanctions. ${ }^{526}$ In the event that a distributor places a complaint against a direct selling company, sanctions for breaches of the Code may include the termination of the direct seller's contract or relationship with the company, refund of payments, issuance of a warning to the company or its direct sellers, or appropriate actions and the publication of such actions or sanctions. ${ }^{527}$

Direct Selling Europe's Code of Ethics also places primary responsibility to observe the Code with its signatories, as established in the foregoing.

In case of consumer complaints, unlike Seldia, the DSE Code requires the two parties to choose an ADR body to solve the dispute. If within a reasonable time no solution can be found to the satisfaction of both parties, the consumer may report a breach of the Code to the Managing Director of DSE. ${ }^{528}$

With regard to complaints among direct selling companies, complaints shall be addressed to the Board of Directors. ${ }^{529}$ According to the Code, the companies are, in the first instance, subject to the Code of Ethics of the association they are members of. ${ }^{530}$ However, in the event that the company is not a member of an association in a certain country, then the DSE Code of Ethics will apply. ${ }^{531}$ Any breach of the Code may nevertheless be reported to the DSE Managing Director by anyone who legitimately considers that any of the Code's provisions have been violated. ${ }^{532}$

\footnotetext{
${ }^{525}$ Ibid.

${ }^{526}$ Article 3.4 of the Seldia Code

${ }^{527}$ Article D.d of the Seldia Code

${ }^{528}$ Chapter V, Article 1 of the DSE Code

${ }^{529}$ Chapter V, Article 2 of the DSE Code

${ }^{530}$ Chapter V, Article 3 of the DSE Code

${ }^{531}$ Ibid.

${ }^{532}$ Ibid.
} 
The first instance of DSE's complaint handling procedure is the Managing Director who contacts the company referenced in the complaint. Should the Managing Director not receive evidence of satisfactory voluntary resolution within 15 working days, he/she will send the report to the Board of Directors, which shall evaluate the report and decide to either close the file due to lack of evidence or open a process of self-discipline in respect of the member company in question. The Board of Directors examines the documentation and conducts a hearing, if requested by the company, and takes a decision by simple majority of votes. The recipient of the self-disciplinary measure is obligated to comply with the decision promptly but no later than 30 working days following notification of the taken measure. ${ }^{533}$

The penalty system of the DSE Code consists of three steps: firstly, if the Board of Directors establishes that there indeed has been a breach of the Code, it will send a note of reprimand to the company in question and shall require compliance promptly but no later than within 30 working days. In the event that the company fails to comply with the note of reprimand within the prescribed timeframe, or if the breach is particularly serious in quality or relevance of Code infringements, the Board of Directors sends it to a measure of censorship, requesting it to comply within a maximum of 30 days. Lastly, should the member company fail to comply on time with the instructions contained in the measure of censorship, the General Assembly of DSE, in the event of a particularly serious breach, will start the process of exclusion in accordance with the Statutes of the Association. ${ }^{534}$ Exclusion of a member from DSE will be published in all cases. ${ }^{535}$

\subsection{Motives of Self-Regulation}

Self-regulation, as a policy option, has aroused interest from policymakers and academia alike, enjoying serious considerations concerning its viability. ${ }^{536}$ For some, selfregulation is a responsive, flexible, informed, targeted phenomenon that encourages compliance ${ }^{537}$ with the 'emphasis being upon gaining a moral commitment from participants, and upon using information, education, technology sharing, and perhaps peer

\footnotetext{
${ }^{533}$ The detailed rules of procedure may be found in Chapter V, Article 3 of the DSE Code

${ }^{534}$ Chapter V, Article 4 of the DSE Code

${ }^{535}$ Chapter V, Article 5 of the DSE Code

${ }^{536}$ Sinclair, D., 'Self-Regulation Versus Command and Control? Beyond False Dichotomies', 19 Law \& Policy, Issue 4 (1997), p. 529-559., p. 530.

${ }^{537}$ Black, J. 'Decentring Regulation: Understanding the Role of Regulation and Self-Regulation in a 'PostRegulatory' World', 54 Current legal problems. Issue 1 (2001), p.103-146., p. 115.
} 
group pressure, as a means to achieve this end'. ${ }^{538}$ Opponents, on the other hand, argue that industry self-regulation serves mainly the interests of the industry and is 'frequently an attempt to deceive the public into believing in the responsibility of an irresponsible industry' ${ }^{539}$ and 'sometimes an excuse for the government for not doing its job, ${ }^{540}$ furthermore, standards and enforcement are often accused of being weak and lack the virtues of government regulation in terms of visibility, credibility and accountability. ${ }^{541}$ The current section will assess which of these factors apply for the direct selling industry self-regulation and what the present state of industry morality is.

The emergence of the direct selling industry's Codes of Ethics dates back to the 1970s United States. It was in these years that the industry was confronted with concerns about the abuse of consumers in the marketplace, and especially consumers falling prey to fraudulent pyramid operators, for which reason it adopted a strict Code of Ethics that safeguarded and protected consumers. ${ }^{542}$ Some twenty years later it was time for the industry to face a whole new set of challenges. 'Some of these challenges were the result of changes in legitimate companies' practices, others of the rebirth of fraudulent pyramid schemes. Advances in technology have also brought about new challenges and yet others are the result of new enforcement actions taken by regulatory agencies. As a consequence, the first part of the 1990s in the United States were marked by multistate actions against notable MLM companies, in part due to reports of inventory loading and unrealistic earnings claims (usually made as part of recruiting pitches), stirring considerable media attention. In response to some companies' deteriorating market place behaviour and the resulting reputational loss combined with the fear that lawmakers might consider significant regulation of direct selling, the US DSA took a strong position and decided to deal with marketplace abuses through aggressive self-regulation. ${ }^{543}$ The Code that had for years prohibited pyramid schemes was amended in 1993 to deal even more specifically with the protection of distributors and has thus become an industry standard'. ${ }^{544}$

With direct selling and multi-level marketing becoming a global phenomenon, an increasing number of national direct selling trade associations have been established and

\footnotetext{
${ }^{538}$ Sinclair, D., 19 Law \& Policy, Issue 4 (1997), p. 534.

${ }^{539}$ Braithwaite, J. 'Responsive Regulation in Australia', Regulation and Australia's Future, edited by Grabosky, P. and Braithwaite, J., (Australian Institute of Criminology, Canberra, 1993), p. 91.

${ }^{540}$ Ibid., p. 91.

${ }^{541}$ Gunningham, N. and Rees, J., 19 Law \& Policy, Issue 4 (1997), p. 363-414, p. 370.

${ }^{542}$ Mariano J. N., Brossi M., Multilevel Marketing: A Legal Primer (2 ${ }^{\text {nd }}$ edition, Publisher: Direct Selling Association US - Washington D.C., 1997), p. 50.

${ }^{543}$ Ibid., p. 49-50.

${ }^{544}$ Ibid., p. 50.
} 
formed the World Federation of Direct Selling Associations (WFDSA). The WFDSA recognised the self-regulatory efforts pioneered by the US DSA, which served as a model for worldwide adoption. ${ }^{545}$

Following the Eastern European transition and the fall of the USSR, the emerging markets were open to new marketing techniques such as direct selling and the inflow of "western" products but were also unfamiliar with pyramid promotional schemes as well as various frauds and abuses connected to the channel and could thus easily become victims of scams. Additionally, even the more mature markets of Western Europe, Japan or the United States could benefit from a uniform, worldwide standard of conduct and legitimate MLM companies could further distinguish themselves from frauds. Consequently, WFDSA adopted Codes of Conduct towards consumers and direct sellers which were in turn to be adopted by all national members of the federation. ${ }^{546}$ The industry Codes thus serve as a foundation of direct selling trade associations in which membership is voluntary and serves as a quasi-trust mark of ethical trading: corporate members must pledge to abide by the rules enshrined in the Codes as a condition of admission and continuation of membership.

Based on the US and WFDSA Codes, the European Codes of conduct were adopted by the regional association, the Federation of European Direct Selling Associations (FEDSA) in 1995 and by the European national direct selling associations. Following the crisis and the eventual split of the European direct selling industry in 2006, the new European trade association Direct Selling Europe with its separate Codes was established.

Although reasons for the split are multiple and are evaluated differently on both sides of the fence, what cannot be ignored is the fact that DSE distinguishes itself as the representative of the 'sustainable, ethical and consumer-oriented direct selling industry in the EU'547 meaning that DSE members have drawn the demarcation line based on morality and business ethics. With DSE's corporate members being predominantly single-level (like Vorwerk) or party-plan (like Tupperware) it is probable that these corporations were not as much in need of protection and credibility of the trade association as other network marketing companies, such as Amway or Herbalife that had to stand trials because of their business models and related pyramid allegations ${ }^{548}$ both in

\footnotetext{
${ }^{545}$ Ibid., p. 52.

${ }^{546}$ Ibid., p. 52-53.

${ }^{547}$ DSE website, “About Direct Selling Europe”, http://www.directsellingeurope.eu/basic-page/about-directselling-europe-dse (last visited 17 September 2014)

${ }^{548}$ Amway was under an FTC investigation in the US in 1979 but was cleared of pyramid scheme allegations and was subsequently cleared of the same allegations by a Belgian court in 1997 and a United Kingdom court in 2008. Similarly, in December 2013 Herbalife won a Belgian appeals court ruling rejecting claims that the
} 
EU Member States as well as in the United States. Nevertheless, Direct Selling Europe's Codes do not contain higher standards or more stringent rules than Seldia's Codes.

Voices raising concerns about the industry morality in the US have been surfacing for some time now but the issues raised have been ignored for many years. In 2009, noted MLM attorney Kevin Thompson published an article 'Pyramid Schemes: Saving the network marketing industry by defining the grey ${ }^{549}$ in which he found that in the trying times of the global crisis, network marketing companies are in the position to offer viable business opportunities to those people who desperately need them. While the industry is poised to meet demands for opportunities, however, the law governing it remains confusing as it contains many cumbersome and complex pitfalls. Ambiguity of rules increases the grey area between legitimate MLMs and pyramids, he said, and in this grey area scammers can proliferate by masquerading themselves as legitimate MLMs when in fact they are nothing but frauds. It is for this reason that narrowlydefined, tight laws with clear safeguards are needed in order to save the honest network marketing businesses. ${ }^{550}$

Three years later, in 2012, after the Court order that shut down BurnLounge (an entity that touted itself as a cutting-edge way to sell digital music through multi-level marketing ${ }^{551}$ ) declaring BurnLounge to be an illegal pyramid scheme, further demands for an industry-wide reform have started to emerge. In another article ${ }^{552}$ of April 2012, Kevin Thompson claimed to see more similarities than differences between BurnLounge and the rest of the companies in the MLM industry, and that in fact the industry was deceiving itself into thinking that everything is fine. Thompson found there were two ways the industry could respond to the BurnLounge Court order of March 2012:

'One option is to seek peace. To try to convince ourselves that the owners were simply reckless. The better option would be to seek improvement by having an honest conversation about the problem. While we easily roll BurnLounge under the bus and refer-

company is a pyramid scheme. The next challenge will have to be faced in the US as the FTC has opened an official enquiry into Herbalife based on pyramid scheme allegations.

549 Thompson, K, 'Pyramid Schemes: Saving the network marketing industry by defining the gray', Scribd, (July 2009), http://www.scribd.com/doc/13639323/Pyramid-Schemes-Saving-the-network-marketingindustry-by-defining-the-gray (last visited 17 September 2014)

${ }^{550}$ Ibid.

${ }^{551}$ Federal Trade Commission Press Release, FTC Action Leads to Court Order Shutting Down Pyramid Scam Thousands of Consumers Burned by BurnLounge, 14 March 2012, http://www.ftc.gov/news-events/pressreleases/2012/03/ftc-action-leads-court-order-shutting-down-pyramid-scamthousands (last visited 17 September)

552 Thompson, K., 'Self-Deception: a cancer holding the MLM industry back', The MLMAttorney, 9 April 2012, http://thompsonburton.com/mlmattorney/2012/04/09/self-deception-a-cancer-holding-the-mlm-industry-

back/ (last visited 17 September 2014) 
ence their junk products as the main reason for their demise, we should at least acknowledge, industry-wide, the major importance of accruing revenue from external customers. ${ }^{553}$

Thompson was strongly arguing for renewal and clearer industry standards that clearly separate pyramid schemes from legitimate MLMs as the current set of rules do not entirely do so. The industry Codes contain ambiguous rules on internal consumption that do provide room for unfair practices, he said. The network industry must be saved through the definition of the grey area between MLMs and pyramids and for that purpose, the problem needs to be acknowledged, honestly discussed and, conclusively, tighter rules must be laid down. The proposed solution was the introduction of a required retail sales rule, like Amway's 70\% rule in the 1970s in the course of the FTC investigation or the Amway requirement of USD200 in retail sales before someone can sponsor other participants when Amway when was tried in the UK for operating a pyramid scheme. ${ }^{554}$

In the meantime, new pyramid schemes emerged: mega-scams such as TelexFree, Cyber Kids, and Fortune Hi-Tech happened and in June 2014, the US Court of Appeals in San Francisco ruled that BurnLounge's marketing methods violated the Federal Trade Commission Act because its distributors paid for the right to sell products and were motivated primarily by payments from the company for recruiting new members ${ }^{555}$ but it also stated that internal consumption in itself does not constitute a pyramid scheme.

Following controversies sparked by hedge fund manager Bill Ackmann in December 2012, an FTC investigation against network-marketing giant Herbalife was opened to assess whether it was a pyramid scheme. In April 2014, the Federal Bureau of Investigation joined the FTC in investigating Herbalife's business practices. Initiated some 30 years after the landmark Amway ruling in 1979 which gave multi-level marketers a pass and laid down the roadmap for the entire industry, ${ }^{556}$ Herbalife won dismissal of the US "pyramid scheme" lawsuit as no fraud was proven, i.e. the fact that the company's nutri-

\footnotetext{
${ }^{553}$ Ibid.

${ }^{554}$ Ibid.

${ }^{555}$ Gullo, K., Bloomberg, 'BurnLounge Ruling in FTC Case Seen as Good for Herbalife', 3 June 2013, http://www.bloomberg.com/news/2014-06-02/burnlounge-shutdown-by-ftc-upheld-by-federal-appeals-court1-.html (last visited 17 September 2014)

${ }^{556}$ Greenberg, H., TheStreet, 'What to Expect from Herbalife Probe', 13 March 2014, http://www.thestreet. com/story/12528628/1/greenberg-what-to-expect-from-herbalife-probe.html (last visited 17 September 2014)
} 
tion clubs are focused on the recruitment of new members instead of product sales could not be substantiated. ${ }^{557}$

Finally, a serious signal indicating the existence of a problem was given to the network marketing industry in the US. In September 2014 AVON, the second largest direct selling company with over USD32 billion in sales in 2013, announced in an open letter its decision to leave the US DSA. The reason of the exit is two-fold: besides AVON's belief that the association's agenda in the US is 'overly focused on the issues of a few specific brands rather than industry-wide challenges', AVON said 'the US DSA's Code of Ethics required updating to better reflect the current state of the industry in the US' ${ }^{558}$ Based on the operation of the US DSA, AVON did not see the US DSA addressing either of the two issues.

The open letter continued to say that AVON considered the Code of Ethics to be a key component of industry self-regulation, wherefore it continues to abide by the WFDSA Codes and the national DSAs' Codes at the local markets.

Like any industry, direct selling and multi-level marketing evolve and the associations that support the direct selling industry need to evolve as well. As one of the largest direct selling companies in the world, AVON claimed to feel that it is its duty and responsibility to protect those just starting out in the industry, as well as those who have made careers as independent direct sellers.

In the US, AVON believes there is a need to enhance the DSA Code of Ethics to better ensure that individuals entering direct selling have the benefit of adequate safeguards. If and when these issues are better addressed by the US DSA in a way that is supportive of the industry as a whole, AVON would re-consider its membership, it said.

There are three major aspects of the AVON business model that the company believes to further safeguard its direct sellers and consumers:

1. The AVON business model does not rely on nor does it encourage sales of inventory, training or business support materials between direct sellers. The core of the business model is the company's direct sellers selling AVON's products to an end consumer.

2. AVON has reasonable return policies. Representatives are not left holding excess inventory.

\footnotetext{
${ }^{557}$ Weber, C., Associated Press, 'A lawsuit accusing Herbalife of being a pyramid scheme has been dismissed, 19 March 2015, http://uk.businessinsider.com/the-lawsuit-accusing-herbalife-of-being-a-pyramid-schemehas-been-dismissed-2015-3? $\mathrm{r}=$ US (last visited 16 June 2015)

${ }^{558}$ AVON Press Release, 'AVON withdraws from the US DSA', 12 September 2014, http://media.avoncom pany.com/index.php?s=10922 (last visited 17 September 2014)
} 
3. AVON limits earnings to three generations. The company does not promise commissions on infinite sales. Rather, AVON primarily promotes and incentivises its direct sellers based on their sales to customers. ${ }^{559}$

The fact that AVON has taken the radical step of leaving the US DSA as well as Seldia and many other national DSAs to join Direct Selling Europe in early 2015 as well as the previously mentioned court cases in the United States indicate that there is in fact an internal crisis emerging along the lines of self-regulation and ethical trading standards. At the core of the issue lies the ambiguity of the pyramid scheme provisions and especially internal consumption in the industry's Codes. Loopholes and ambiguity in the framework of these norms give rise to illegitimate market place behaviour that is seen as detrimental for the entire industry and, although leaving these gaps open may serve some of the DSA's biggest members' interests (at least on the short-term), closing these holes could certainly be in the interests of the industry in the long run through the establishment of a clear regulatory framework that would draw a clear distinction between legal and illegal schemes which would thereby increase legal certainty.

In summary, it was demonstrated how two major waves of illegal and unfair market place behaviour have necessitated the regulation and self-regulation of various aspects of the direct selling industry. The first wave came in the 1970s whereby the consumer grievances and scams led to the introduction of a Code of Ethics that safeguarded and protected consumers, whereas the second wave in the 1990s and the subsequent introduction of specific protective measures and industry standards were meant to safeguard distributors. The introduction of self-regulatory codes was aimed at controlling deteriorating market place practices and thereby protecting consumers and direct sellers on the one hand but, at the same time, the main motivation was the industry's aspiration to control reputational loss and the fear that legislators might consider significant regulation of direct selling. The clearest example of using the industry's engagement in selfregulation as an argument in lobbying was introduced in sub-section 4.3.2. concerning the defence of the current pyramid scheme definition against potential revisionary intents that could have resulted in less favourable regulation from the industry's perspective. It was explained in section 5.2. in detail how the industry standards that had been put in place have been offering safeguards that very often -to this day- go beyond the letter of statutory law. It can therefore be concluded that while the direct selling industry's self-regulatory efforts are undoubtedly and primarily motivated by self-interest, they also serve the interests of consumers and direct sellers through the adherence to both statutory law as well as to high industry standards. This overlap of interests as well

${ }^{559}$ Ibid. 
as the binding nature of the Codes under European law contribute to the credibility of the self-regulatory endeavour. Current challenges are posed by the fact that a key area of industry standardisation has remained very loosely regulated, causing not only an internal dispute and moral crisis within the industry itself, but the issue also raises questions to legislators and the judiciary in terms of the permissibility of certain business practices.

\subsection{Industry Self-Regulation as an Agent of European Harmonisation}

The European Codes of Ethics of the direct selling industry form an integral part of a worldwide private regulatory endeavour to respond to global concerns and morality shortcomings. The Codes are voluntary schemes providing an umbrella of protection and a quasi-trust mark to members that pledge to abide by the rules that at times go above the letter of law, thereby allowing corporate members to distinguish themselves as legitimate direct selling companies.

The relevance of private regulation, mainly in the form of self-regulation in the European Union, has been recognised by the Unfair Commercial Practices Directive, which has also defined the liability of code owners and signatories. Although selfregulation was initially considered as a means to overcome legal diversity and a potential complement to EU regulation by the European Commission on the road towards the establishment of the Unfair Commercial Practices Directive, ${ }^{560}$ despite the initial intent to endorse pan-European codes of conduct and even to equip them with an implicit "presumption of conformity", ${ }^{561}$ the role of self-regulation ended up considerably smaller than planned in the UCPD. Hence, it was decided that in sectors where there are specific mandatory requirements regulating the behaviour of traders, these will also provide evidence as to the requirements of professional diligence in that sector. ${ }^{562}$

Although the European legislator did not grant the "safe harbour status" (the presumption of legality) to traders who are signatories of codes, ${ }^{563}$ non-adherence to codes is penalised. Once an undertaking commits to comply with commitments contained in codes of conduct by which the trader has undertaken to be bound and breaches those commitments, the violation of the code will be qualified as a misleading commercial practice. ${ }^{564}$ In other words, non-compliance with a voluntary code of conduct qualifies as an unfair commercial practice and as such is outlawed by the UCPD. While some

\footnotetext{
${ }^{560}$ Green Paper on EU Consumer Protection, $\operatorname{COM(2001)~final~531,~p.~} 5$ and 15.

${ }^{561}$ Follow-up Communication to the Green Paper on EU Consumer Protection, COM (2002) final 289, p. 11.

${ }^{562}$ Recital 20 UCPD

${ }^{563}$ Follow-up Communication to the Green Paper on EU Consumer Protection, COM (2002) final 289, p. 11.

${ }^{564}$ Article 6(2) lit. b of the Unfair Commercial Practices Directive
} 
authors like Pavillon see the EU regulation of codes of conduct as a potential evidence of unfairness, ${ }^{565}$ the public enforceability of the codes increases their credibility significantly and is therefore beneficial for code owners and signatories.

Self-regulation, according to Cafaggi, performs important functions in the process of harmonising European contract law ${ }^{566}$ by bringing uniformity to industry standards. According to this theory, two main choices may characterise the application of selfregulation as a means to harmonise European contract law:

1. Complement or substitute - Self-regulation may be a total or partial device for harmonisation; it can either be a complement to hard or soft law harmonisation or, alternatively, in certain areas it can substitute hard law harmonisation.

2. General or sector specific - Self-regulation may generate general standard forms or it can be used for individual sectors. ${ }^{567}$

The choice between the first two options, whether self-regulation fulfils a complementary or substitutional function depends on the form of legislation, whereby the role of private regulation increases in a more principle-based legislative system. Practically speaking, self-regulation is complementary in the event when it specifies and interprets existing legislation. It is a substitute when it harmonises contractual relationships otherwise regulated at State level. ${ }^{568}$

From an institutional perspective, says Cafaggi, self-regulation can complement:

- Legislative functions by contributing to the definition of contractual terms,

- Regulatory functions by defining sector-specific guidelines or by introducing cognitive intermediaries,

- Interpretative functions by offering guidelines to individual companies when they contract with other firms or consumers,

- Monitoring functions of European contract law by verifying correct implementation of EU law at Member State level,

- Enforcement by defining sanctions against their members in case of violations.

\footnotetext{
${ }^{565}$ Pavillon, C.M.D.S., 'The Interplay between the Unfair Commercial Practices Directive and Codes of Conduct', 5 Erasmus Law Review, Issue 4 (2012), p. 269.

${ }^{566}$ Cafaggi, F., 'Self-regulation in European Contract Law', 1 European Journal of Legal Studies, Issue 1, (2007) (page numbering is to be understood as the page number of the Article itself at http://www.ejls.eu/1/10UK.pdf) p. 1.

${ }^{567}$ Ibid., p. 1.

${ }^{568}$ Ibid., p. 2.
} 
Looking at the substantive perspective, self-regulation can contribute to the formulation of standard contract terms according to different models and to their correct administration, to the establishment of codes of conduct that affect (1) the content of the contract, (2) the bargaining procedure and ensuring compliance with EU legislation, (3) more general economic activities of the regulated (e.g. introduction of licensing or quality control for certain activities). ${ }^{569}$

Direct selling industry self-regulation in Europe, the specification of professional diligence, is based on a sector-specific set of private norms developed by the US DSA, subsequently adopted by WFDSA and FEDSA/Seldia and, following the industry split, Direct Selling Europe. As indicated in section 5.2., the Codes govern conduct towards consumers (B2C) and conduct towards direct sellers and other direct selling companies (B2B) and can be viewed as agents of harmonisation in both aspects.

As an important preliminary note, it must once again be underlined that the European direct selling industry's (i.e. FEDSA's) Codes were adopted in 1995 - a year shy of two decades before the Consumer Rights Directive had entered into force and over a decade before the Unfair Commercial Practices Directive and the Misleading and Comparative Advertising Directive were put in place. To put it differently, the direct selling industry's harmonised system of private norms preceded European legislation and at times formed the basis of future legislation making a further, highly valid case for full harmonisation in the EU.

The Codes towards consumers regulate the classic features of an off-premises consumer contract: traders' duty to provide consumers with accurate pre-contractual information, the withdrawal right and performance. In general, some of the Consumer Codes' provisions were, from an institutional perspective, complementary to the Doorstep Selling Directive in terms of the assumption of legislative and regulatory functions prior to the entry into force of the Consumer Rights Directive and the Unfair Commercial Practices Directive. For example, this was done through the prescription of standardised pre-contractual information provision obligations or the prohibition of misleading commercial communication.

Currently, following the introduction of the said full harmonisation Directives, the legislative function of the consumer codes has been reduced to the provisions prohibiting referral sales (a measure currently missing from the UCPD) and in Member States where there is a threshold introduced for low value transactions that are exempt from the scope of the CRD (Art.3(4)) the Codes' protection for low value transactions substitute statutory law.

${ }^{569}$ Ibid., p. 7. 
The remaining measures have more of an interpretative nature, offering guidance on performing fair commercial conduct towards consumers and thereby ensuring compliance with EU law (i.e. by prescribing the respect of privacy, or the prohibition to exploit elderly or ill consumers).

The relevance of private regulation being usually greater in the field of lex mercatoria as a trend, ${ }^{570}$ the direct selling Codes towards direct sellers and companies play a very important role in complementing European law. The Codes towards direct sellers and companies fulfil significant legislative and regulatory functions while standardising fair trade between businesses.

First of all, the greatest significance of the industry's Codes towards direct sellers is the fact that they complement the European pyramid regulation by providing key safeguards to direct sellers that EU law fails to do, especially because the present definition is restricted to $\mathrm{B} 2 \mathrm{C}$ relations. The industry Codes, on the other hand, have laid down rules of protection against the hallmarks of pyramid schemes. High entry fees, inventory loading and deceptive earnings claims are prohibited under the Codes and a mandatory buy-back policy (Seldia even gives a 7-day withdrawal right to direct sellers) is prescribed in all cases.

Secondly, substitution of statutory law in B2B transactions also succeeds in Member States where the scope of the CRD has not been extended to small businesses (under Recital 13), but Seldia's Codes nevertheless provide direct sellers a 7-day right to withdraw.

Monitoring and ensuring the uniform enforcement of (private) norms throughout the European Union is also an important function that the European trade associations as code owners fulfil. What has already been highlighted as a further development in terms of consumer redress in the EU is the establishment of Seldia's sector-specific panEuropean ADR Body, the European Code Administrator, for cases when the parties do not fall under the same jurisdiction.

To sum up, the current section was devoted to the examination of the way direct selling self-regulation acts as an agent of European legal harmonisation. It has been established that the industry Codes are standardised sector-specific normative systems that cover both consumer contracts as well as the relevant fields of lex mercatoria that preceded the introduction of fully harmonised statutory law, making a case for convergence in the European Union already in 1995. Within the framework and limitations of European consumer- and competition law, the Codes, as agents of harmonisation, were found to supplement, substitute, interpret and complement EU law and the enforcement thereof.

\footnotetext{
${ }^{570}$ Cafaggi, F., 'Self-regulation in European Contract Law', EUI Working Paper LAW No. 2006/43, European University Institute, Badia Fiesolana (2006), p. 7.
} 


\subsection{Conclusion}

Direct selling industry self-regulation in Europe is part of a global trend that raises industry standards through market integration, but it is also a comprehensive response given to a general morality deficit, placed in the context of an increasingly harmonised economic and legal environment. Direct selling trade associations, as owners of the Codes, operate voluntary schemes of which corporations can become members by pledging to abide by the rules as a condition of admission and continuation of membership. Through the enforcement of the industry's private set of standards, membership of the direct selling associations is a quasi-guarantee of law abidance and compliance with fair trading standards. The credibility of the Codes is enhanced by their legally binding nature in the EU, helping signatories distinguish themselves from non-signatories and crooks.

Looking at the motivations behind the industry self-regulation, it was observed that the industry's -and especially the network marketing industry's- core interest is the establishment of tight and narrow rules and safeguards that decrease the grey area that separates good from bad, legitimate MLMs from fraudulent pyramids, in order to disallow the proliferation of scams that cast a negative light on the entire industry and thereby increase regulatory activity. Introduction of both Codes (Codes for consumer and Codes for businesses) were found to be based on the industry's self-interest, yet it was also established that engagement in self-regulation has increased direct selling corporations' compliance and was thus also beneficial to consumers and direct sellers. While the global self-regulatory endeavour - made under significant external pressure - was found to be a positive achievement, symptoms of a new internal morality crisis have surfaced in the United States but are unlikely to stop there. It was concluded that the industry will most likely have to revisit key issues on the permissibility of internal consumption and the possible limitation of the number of distributors' downline levels.

From another perspective, European Codes can be seen as a concentrated, collective effort of the sector to establish a normative framework with uniform standards throughout Europe, thus setting a benchmark of fairness, and thereby decreasing legal fragmentation.

As agents of harmonisation, the Codes are complementary to EU law in certain key respects, most importantly in the field of lex mercatoria, and more specifically, the pyramid regulation. While the Consumer Rights Directive and the Unfair Commercial Practices Directive have not left considerable gaps to be filled by private regulation, the body of law governing transactions between businesses (between direct selling companies and between direct selling companies and direct sellers) is in need of supplementa- 
tion. The ambiguous anti-pyramid statute of EU law is complemented in its scope, as the industry Codes provide protection to direct sellers and not just to consumers, as well as through the provision of specific safeguards that EU law comes short of.

From the perspective of enforcement, European consumer redress has been further developed thanks to the pan-European ADR body, the European Code Administrator that Seldia set up in order to handle complaints by consumers and traders falling under different jurisdictions. 


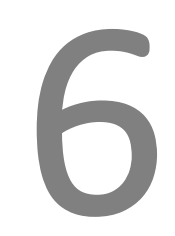

Dossier 4:

Entrepreneurship Promotion 



\subsection{Introduction}

The present chapter is dedicated to the introduction and deeper understanding of the lobbying dossier concerning the promotion of entrepreneurship. One might wonder why the industry lobby's efforts to promote entrepreneurship have been included in the primarily legal enquiry into the direct selling industry's advocacy, as it is not a legislative lobbying dossier. The reason is that, on the one hand, entrepreneurship promotion is the single most comprehensive and significant PR venture the direct selling industry lobby has engaged in and, on the other hand, because there could be room -and demand from direct selling companies- to further develop this dossier to include legislative advocacy goals and action.

It is, therefore, these two aspects that the current enquiry aims to look into: the exploration of the PR efforts to promote entrepreneurship in Europe and, secondly, the need to further develop the dossier to include legal matters concerning the regulatory environment for SMEs.

Accordingly, a brief overview of the European entrepreneurship policy and its intended role in the economic recovery will be provided as a basis of the present chapter. Thereafter, the non-legislative public relations aspect of the direct selling industry will be described: how, within the European entrepreneurship policy framework, the industry lobby has discovered an opportunity to reinvent the entire direct selling method's image and narrative by tailoring it to the contemporaneous political discourse and policy aims. Besides the highly successful and praiseworthy PR efforts of the industry, it will also be highlighted what is currently missing from the industry lobby: the inclusion of much needed legislative advocacy at European and national level to reduce regulatory burden on SMEs, accompanied with recommendations for the industry sector as to how this dossier could be improved.

\subsection{The European Entrepreneurship Policy}

Entrepreneurship is a widespread concept that lacks a firm definition, given the multiple aspects it entails, such as the development of new business, implementation of innovation, development of new products and services, etc. Generally, for a better understanding of the entrepreneurship concept, it can be stated that it refers to the action taken by one or many parties in order to develop and implement a new thing or concept. ${ }^{571}$

\footnotetext{
${ }^{571}$ Strambeanu, G., Popovici, N., Moraru, C., 'Entrepreneurship: a Source of Economic Growth in EU', 6 EIRP Proceedings (2011), p. 698-705., p. 699.
} 
The importance of entrepreneurship in business and social life is paramount, because entrepreneurship encourages the creation of new business and jobs, contributes to the development of new products and services, stimulates research and knowledge, improves state budget revenues and creates wealth. ${ }^{572}$

The global crisis has escalated policymakers' and economists' attention on entrepreneurship and its positive socio-economic effects. Based on a survey conducted in the United States between 1996 and 2009, covering more than 130.000 people in 250-plus metropolitan areas, Fairlie found that

'recessions decrease potential business income and wealth, but on the other hand restrict opportunities in the wage/salary sector leaving the net effect on entrepreneurship ambiguous. [...] Regression estimates indicate that local labour market conditions are a major determinant of entrepreneurship. Higher local unemployment rates are found to increase the probability that individuals start businesses. [...] Additional regression estimates indicate that individuals who are initially not employed respond more to high local unemployment rates by starting businesses than wage/salary workers. The results point to a consistent picture - the positive influences of slack labour markets outweigh the negative influences resulting in higher levels of business creation. Using the regression estimates for the local unemployment rate effects, it was found that the predicted trend in entrepreneurship rates tracks the actual upward trend in entrepreneurship extremely well in the Great Regression. ${ }^{573}$

Contrary to the findings of Fairlie's research results in the United States, in Europe, since the beginning of the economic crisis, self-employment has in fact become a less attractive option: in 2013 as many as 58\% of Europeans preferred to work as employees as opposed to $49 \%$ in $2010 .{ }^{574}$ Furthermore, there are fewer entrepreneurs in Europe than in the United States or in emerging countries. The Global Entrepreneurship Monitor points out that in 2010, "early stage" entrepreneurs constituted 2.3\% of the Italian population and $4.2 \%$ of the Germans'. The respective figures for the United States, China and Brazil are $7.8 \%, 14 \%$ and $17 \% .{ }^{575}$

The reasons for the lower rate of entrepreneurial activities in Europe have been widely researched and looked into in the context of the determinants of entrepreneur-

\footnotetext{
${ }^{572}$ Ibid., p. 699.

${ }^{573}$ Fairlie, R. W., 'Entrepreneurship, Economic Conditions, and the Great Recession', 22 Journal of Economics \& Management Strategy, Issue 2 (2013) p. 207-231., p. 207. (Abstract)

574 EurActiv.com, 'Re-inventing Europe's entrepreneurial spirit', 28 May 2013, available at http://www.euractiv.com/innovation-enterprise/reinventing-europe-entrepreneuri-analysis-528098 (last visited 17 September 2014)

${ }^{575}$ Ibid.
} 
ship: Grilo and Thurik suggest that risk-tolerance (a key factor in entrepreneurship) is generally lower in EU Member States than in the United States and is therefore a major contributor to the lower level of entrepreneurial activities in Europe. ${ }^{576}$

Moreover, fragmentation in general poses a problem: the business environment in certain Member States is not favourable for starting new enterprises due to a variety of reasons such as red tape or strict bankruptcy laws, whereas cross-border activities are hindered by issues of double taxation or other taxation mismatches. ${ }^{577}$

Having recognised the problem, European policymakers have been engaged in the promotion of entrepreneurship and the encouragement of small- and medium sized enterprises in the EU through political means.

To start with, entrepreneurship was set to be one of the key objectives of the Lisbon Agenda already in 2000. In the same year, the Council called for action in favour of small enterprises and entrepreneurship, notably by adopting the European Charter for Small Enterprises to improve the business environment for SMEs in ten key areas such as education and finances, which was endorsed by the Feira European Council.

In 2003, the Commission published a Green Paper on "Entrepreneurship in Europe", focusing on the establishment and growth of new businesses and, in order to stimulate discussion between key stakeholders, on the means to promote entrepreneurship in Europe. Following the Green Paper consultation process, in 2004 a new Action Plan, "The European Agenda for Entrepreneurship", ${ }^{578}$ was released. The Action Plan was designated to the establishment of a strategic framework for encouraging entrepreneurship, and defined the key actions to be taken: ${ }^{579}$ (1) Fuelling entrepreneurial mindsets; (2) Encouraging more people to become entrepreneurs; (3) Gearing entrepreneurs for growth and competitiveness; (4) Improving the flow of finance; (5) Creating a more SME-friendly regulatory and administrative framework.

\footnotetext{
${ }^{576}$ Grilo, I. and Thurik, A. R., 'Entrepreneurship in the Old and New Europe', in Entrepreneurship, Growth, and Innovation: the Dynamics of Firms and Industries: International Studies in Entrepreneurship, Santarelli, E. (ed.), (Springer Science, Berlin, 2006), p. 75-103., p. 82.

${ }^{577}$ European Commission, Communication From The Commission To The European Parliament, The Council, The European Economic And Social Committee And The Committee Of The Regions: Entrepreneurship 2020 ACTION PLAN - Reigniting the entrepreneurial spirit in Europe European Commission, Entrepreneurship 2020 Action Plan, Brussels, 9 January 2013, COM(2012) 795 final, p. 11.

${ }^{578}$ Commission of the European Communities, Communication From The Commission To The Council, The European Parliament, The European Economic And Social Committee And The Committee Of The Regions Action Plan: The European agenda for Entrepreneurship European Commission, The Action Plan: The European Agenda for Entrepreneurship, Brussels, 11 February 2004, COM (2004) 70 final ${ }^{579}$ Sternberg, R., 'Interregional Disparities, Entrepreneurship and EU Regional Policy', in The Dynamics of Entrepreneurship, Maria Minniti (ed.) (Oxford University Press, Oxford, 2011), p.153-181., p. 163.
} 
In the meantime, the crucial role of SMEs in creating growth was explicitly recognised by the European Council and the need for a regulatory environment that was simple and transparent and conformed to the "think small first" principle was emphasised. Accordingly, "better regulation" has become a centrepiece of the Commission's "Partnership for Growth and Jobs", the renewed "Lisbon Strategy" launched in the spring of 2005.

In the framework of the European Recovery Plan, reflecting the Commission's political will to recognise the central role of SMEs in the EU economy as well as to put into place a comprehensive SME policy framework for the EU and its Member States, ${ }^{580}$ the Commission introduced the Small Business Act ${ }^{581}$ in 2008. The aim of the document is to achieve a breakthrough in EU SME policy in order to release the full potential of $\mathrm{SMEs}^{582}$ and to improve the overall approach to entrepreneurship. Key points of the Small Business Act are built around the establishment of a better regulatory environment based on the "Think Small First" principle, the creation of SME-friendly public administration or the adaption of public policy tools to SMEs' needs.

As a follow up to the Small Business Act review of April 2011 and of the industrial policy communication adopted in October 2012, the Entrepreneurship 2020 Action Plan (COM (2012) 795 final) was released, setting out a renewed vision and a number of actions to be taken at both EU and Member State level to support entrepreneurship in Europe. ${ }^{583}$

Adopted in January 2013, the Entrepreneurship 2020 Action Plan is a blueprint for the development of an entrepreneurial culture across Europe and aims to unleash Europe's entrepreneurial potential, envisaging far-reaching cultural and structural change through the support of entrepreneurial endeavours.

\footnotetext{
${ }^{580}$ Commission of the European Communities, Communication From The Commission To The Council, The European Parliament, The European Economic And Social Committee And The Committee Of The Regions "Think Small First" A "Small Business Act" for Europe $\{$ SEC(2008) 2101\} $\{$ SEC(2008) 2102\}, Brussels, 25 June 2008, $\operatorname{COM}(2008) 394$ final, p.1.

${ }^{581}$ Commission of the European Communities, Communication From The Commission To The Council, The European Parliament, The European Economic And Social Committee And The Committee Of The Regions "Think Small First" A “Small Business Act” for Europe \{SEC(2008) 2101\} \{SEC(2008) 2102\}, Brussels, 25 June 2008, $\operatorname{COM}(2008) 394$ final

${ }^{582}$ Commission of the European Communities, Commission Staff Working Document accompanying the COMMUNICATION FROM THE COMMISSION TO THE EUROPEAN PARLIAMENT, THE COUNCIL, THE EUROPEAN ECONOMIC AND SOCIAL COMMITTEE AND THE COMMITTEE OF THE REGIONS Think Small First A Small Business Act for Europe Impact Assessment $\{\mathrm{COM}(2008) 394\}\{\operatorname{SEC}(2008)$ 2102\}SEC(2008) Brussels, SEC(2008) 2101.

${ }^{583}$ European Commission, Communication From The Commission To The European Parliament, The Council, The European Economic And Social Committee And The Committee Of The Regions Entrepreneurship 2020 Action Plan Reigniting The Entrepreneurial Spirit In Europe, Brussels, 9 January 2013, Com(2012) 795 Final, p. 3.
} 
The document suggests that the three pillars of action should be: (1) entrepreneurial education and training; (2) strengthening framework conditions for entrepreneurs; and (3) reaching out to specific groups. The groups that the Action Plan identifies as those that hold significant entrepreneurial potential are women, seniors, migrant entrepreneurs and the unemployed, especially young people. It is also these social groups that have been found to be underrepresented amongst entrepreneurs and are therefore subjects of targeted initiatives which have the purpose to enable members of the identified groups to start their own businesses.

New businesses need specific care, according to the Action Plan, which proposes intervention in six key areas to remove existing obstacles impeding their creation and growth: (1) access to finance; (2) support for entrepreneurs in the crucial phases of the business lifecycle and their growth; (3) unleashing new business opportunities in the digital age; (4) transfers of businesses; (5) bankruptcy procedures and second chance for honest entrepreneurs; and (6) Regulatory burden reduction.

To sum up, the current section has highlighted the positive influences and, conclusively, indicated the significance of entrepreneurship and the role of SMEs in overcoming the economic recession. A brief international comparison of data concerning entrepreneurial spirit has revealed that Europeans are less inclined to become entrepreneurs than Americans or those residing in transitioning economies, largely due to the fact that Europeans tend to have a lower level of risk-tolerance and are more inclined to avert risk. Additional obstacles to entrepreneurship in the EU are posed by the widely differing conditions (in terms of labour law, access to finance, taxation or bankruptcy laws, for instance) and start-up environments in the Member States. In an effort to overcome the obstacles and divergence as well as to promote entrepreneurship, the European policymaker has taken various political measures purposing the stimulation of entrepreneurial spirit and the reduction of regulatory burden on SMEs.

\subsection{Entrepreneurship as a Lobbying Dossier}

With the grave statistics of Europeans' low willingness to start their own businesses and European policymakers' considerable efforts to promote entrepreneurship, it did not take long for Seldia to realise the immense potential this new policy beholds from an advocacy and PR perspective. It is almost self-evident that an industry so deeply rooted in entrepreneurial values as direct selling would attempt to benefit from the favourable political thematic in trying to improve its distorted image. 
Underlining the fact that direct selling is at the heart of entrepreneurship is that, according to Seldia, 5.18 million direct sellers were active in the EU in 2013, ${ }^{584}$ that is about one-fourth of the 20.3 million SMEs in Europe, ${ }^{585}$ which in itself is a convincing figure. Increasing the number of distributors (entrepreneurs) through the promotion of direct selling in the context of entrepreneurship is naturally a primary goal for the industry, and is closely followed by the need to improve the highly distorted industry image. The promotion of entrepreneurship as a lobbying dossier is meant to be the stone to kill these two birds with.

By and large, building upon the blocks provided by the European entrepreneurship policy and the lack of entrepreneurial spirit in Europe has allowed the industry advocacy to use this setting to both promote its business as well as to revise the industry's controversial public perception by systematically repackaging the industry image, thus adjusting the business narrative to the contemporary political and economic context. Results of this proactive process of image management -as a cardinal lobbying objective- will be described and evaluated in the following sub-section (6.3.1.). Thereafter, as specific fields of action of entrepreneurship advocacy, Amway's efforts to contribute to entrepreneurship promotion through the funding of academic research will be described (6.3.2.), to be followed by the introduction of Seldia's assertive women entrepreneurship lobby (6.3.3.) in this present section.

\subsubsection{Redefinition of the Industry Image}

The policy issue of entrepreneurship has given way for industry advocacy to give a new, appealing spin to the industry image, tailored to the current political and economic discourse and semantics. The conventional image of direct selling as a retail channel where persons are being coerced into joining a network through aggressive recruitment methods has been revisited and systematically repackaged by Seldia's public relations experts.

Direct selling companies -according to the state-of-the-art narrative- operate as quasi business incubators: providing distributors with well-tried products, a tested sales method and a wide array of business support, and thereby fostering and supporting the

\footnotetext{
${ }^{584}$ The statistics are not representative and it must also be noted that the definition of SMEs under EU law is not necessarily the same as Seldia's definition of direct sellers' enterprises.

${ }^{585}$ European Commission, 'A Recovery on Horizon?', Annual Report on European SMEs 2012/2013, , p. 10., http://ec.europa.eu/enterprise/policies/sme/facts-figures-analysis/performance-review/files/supportingdocuments/2013/annual-report-smes-2013_en.pdf (last visited 17 September 2014)
} 
establishment and development of small- and micro-businesses in a safe and low-risk environment ideal for the risk-averse Europeans.

The risk to be taken by new distributors is minimal: a business can be started simply through registration with a direct selling company and the purchase of a starter-kit, which is usually a low investment. ${ }^{586}$ What is more, distributors of Seldia member companies are entitled to at last seven days of withdrawal under the Code of Ethics, ${ }^{587}$ but can also benefit from its buy-back policies ${ }^{588}$ under which direct selling companies are required to repurchase all unused or undamaged products from the distributor upon the termination of the partnership.

Education, trainings or training materials are supplied by the direct selling company free of charge or at a reasonable price to distributors, in line with the first pillar of the Entrepreneurship 2020 action plan. The aim of the product- and marketing- related trainings are to motivate direct sellers' professional growth and appropriate operation in the market. In addition, distributors' uplines or business leaders -as role models- offer guidance, best practices and mentorship based on their own experience to distributors. Self-fulfilment being an important aspect of entrepreneurship, distributors who have achieved appropriate sales figures gain rewards and recognition of their results.

It must be noted that this aspect of the industry's presentation, as a sector of "safer" entrepreneurship, is not entirely new. In fact, it has already been explored to some extent in the academic literature, although with a much more negative overtone. Kuntze ${ }^{589}$ as cited by Fu Dai, ${ }^{590}$ has studied the industry on the basis of the symbolic self-completion theory, an idea postulating that when important symbols -indicators of self-definition- are lacking, the person will strive after further, alternative symbols of self-definition. ${ }^{591}$ Application of the symbolic self-completion theory suggests that network marketers prefer the title of entrepreneurs instead of actually doing what it entails, says Kuntze, and calls network marketers entrepreneurial dreamers. Distinctive differences between direct sellers and traditional entrepreneurs, according to Kuntze, are multi-fold: i) traditional entrepreneurs are considerably and by definition more innova-

\footnotetext{
${ }^{586}$ Seldia member companies do not sell high-ticket items, therefore, start-up costs are relatively low.

${ }^{587}$ Article B.g of the Seldia Code

${ }^{588}$ Chapter III Article 7 of the DSE Code and Article B.h of the Seldia Code

${ }^{589}$ Kuntze, R.J., The Dark Side of Multilevel Marketing Appeals to the Symbolically Incomplete, 2001, unpublished PhD dissertation, Arizona State University, Arizona as quoted by Fu Dai in 'A Model of Network Marketing Business Entrepreneurial Performance' PhD School of Management, The University of Technology, Sydney, 2012, p.16., http://epress.lib.uts.edu.au/research/bitstream/handle/10453/20411/02Whole.pdf?se quence $=2$ (last visited 17 September 2014)

${ }^{590} \mathrm{Fu}$ Dai, A Model of Network Marketing Business Entrepreneurial Performance, 2012, p. 36-37.

${ }^{591}$ Wicklund, R.A. \& Gollwitzer, P.M., 'Symbolic self-completion, attempted influence, and self-deprecation', 2 Basic and Applied Social Psychology, Number 2. (1981), p. 89-114, p. 89.
} 
tive ii) direct sellers' motivation for achievement is extrinsically motivated whereas traditional entrepreneurs' drive is intrinsic; iii) direct sellers' locus of control is more external than that of traditional entrepreneurs; and iv) the motivation to approach the entrepreneurial function of direct sellers is more symbolic than that of traditional entrepreneurs. ${ }^{592}$

The redefined image of the industry successfully increases the political marketability of the direct selling industry as, at least in theory, it is perfectly suitable to provide a concrete option for the realisation of European policymakers' aim to boost entrepreneurship. In the present economic and political context where entrepreneurship is cherished and seen as a motor of recovery, the entrepreneurial values of the direct selling industry reconceptualise the public image of the industry in a more favourable manner.

\subsubsection{Funding Entrepreneurship Research}

As a first attempt of the industry advocacy to outline entrepreneurial values of direct selling, Amway, one of the leading American direct selling companies, every year commissions an annual research project on entrepreneurship. Orchestrated by its European headquarters in Munich, the project is an individual lobbying venture of the company targeting European and national policymakers, media, academia and other relevant stakeholders.

The overall aim of the annual entrepreneurship studies is to understand what drives entrepreneurship as well as to 'facilitate the growth of self-employment by realising concrete and socio-political thought-provoking impulses'. ${ }^{593}$ To this end, the 2011 report studied family-friendly opportunities (with a special attention to women), in 2012 the role of self-employment as a labour model was discussed, whereas the 2013 study assessed the entrepreneurship potential in the EU (and worldwide) and examined the obstacles -such as the fear of failure- that hinder entrepreneurial culture. ${ }^{594}$ The studies provide statistics about the entrepreneurial attitudes in various countries partaking in the surveys as well as aggregated European (and, in 2013, global) data, where relevant.

In addition to attempting to understand entrepreneurial trends and attitudes, Amway also 'takes on the responsibility for engaging in public discussion on entrepreneurship - providing decision makers in politics, economics and society with a basis of

\footnotetext{
${ }^{592}$ Kuntze, R.J., The Dark Side of Multilevel Marketing Appeals to the Symbolically Incomplete, 2001, unpublished $\mathrm{PhD}$ dissertation, Arizona State University, Arizona as quoted by Fu Dai in A Model of Network Marketing Business Entrepreneurial Performance 2012, p. 184.,

${ }^{593}$ Amway Global Entrepreneurship Report 2013, p. 1, http://assets1.bywebtrain.com/501483/2013_amway_ global_entrepreneurship_report_1.pdf?r=1280 (last visited 17 September 2014)

${ }^{594}$ Ibid., p. 1.
} 
measures to encourage the foundation of businesses'. ${ }^{595}$ In other words, the goal is to establish contacts with policymakers to attempt to initiate a public discourse with the participation of Amway both at European as well as at national level. Certainly, an additional aim is to highlight the benefits direct selling (and Amway) has to offer: a business opportunity that is family-friendly and as such is ideal for women, requiring only a lowrisk investment which fits the nature of risk-averse Europeans who tend to fear failure.

Along these lines, Amway presents the European results in the European Parliament every year, creating a platform for Amway advocacy to outline the advantages the company has to offer entrepreneurial minded people and to demonstrate unity with policymakers with respect to the promotion of entrepreneurship.

All in all, having carried out academic research annually since 2011, Amway has been the pioneer of entrepreneurship promotion amongst other direct selling industry lobbyists in Brussels. While other direct selling firms do not engage in individual advocacy concerning entrepreneurship at all and because Seldia only started its promotional campaigns on women entrepreneurship in 2013, Amway's efforts have been innovative in this respect. Findings of the surveys bear relevance for the selected aspects of entrepreneurial research, yet the somewhat repetitive nature of the reports and their presentations in the European Parliament have resulted in the decreasing interest of policymakers in the project, as noted already in 2013. Nevertheless, the Amway entrepreneurship study has prepared the grounds for the ultimate breakthrough in the industry lobby: Seldia's outstanding campaigns and advocacy concerning women entrepreneurship, as will be seen in the subsequent section.

\subsubsection{Championing in Women Entrepreneurship (Advocacy)}

Women are the greatest untapped entrepreneurial potential in Europe - but not for the direct selling industry. While, according to Eurostat, only one third of the self-employed in Europe are women and only around 30\% of start-ups are run by women, ${ }^{596}$ the vast majority (79\%) of direct sellers are female in the EU. ${ }^{597}$

The reasons why women tend to favour direct selling is multi-fold: the most popular products sold through this channel are cosmetics, personal care and houseware items,

\footnotetext{
${ }^{595}$ Ibid., p. 1.

${ }^{596}$ As cited by Franco, A., 'The entrepreneurial gap between men and women' (30/2007), 2007, p. 2., http://epp.eurostat.ec.europa.eu/cache/ITY_OFFPUB/KS-SF-07-030/EN/KS-SF-07-030-EN.PDF (last visited 17 September 2014)

597 The figure has been drawn from Seldia's statistical report from 2012. The statistics is not representative. In: Seldia, 'Representing direct selling in Europe', Annual Report 2012-2013, p. 3., http://www.seldia.eu/images/ pdf/SELDIA_AR_2013.pdf (last visited 17 September 2014)
} 
all of which are traditionally considered more suitable for women to trade with. Secondly, the sales method and owning one's own business allows distributors to work flexible working hours, thus making it easier for women to find a balance between their work and family life. Thirdly, low-entry barriers do not require a significant starting capital and avoid the difficulties connected to accessing finance - a frequent economic obstacle to women entrepreneurship that has been identified by a Commission study on women entrepreneurship entitled "Promotion of Women Innovators and Entrepreneurs". ${ }^{598}$

Based on these grounds, it was not long before Seldia established that women entrepreneurship could become the ultimate selling point of the industry advocacy. The issue of women entrepreneurship is popular, uncontroversial and direct selling excels in it.

The intensive women entrepreneurship advocacy of Seldia started in February 2013, just after the release of the Entrepreneurship 2020 Action Plan, with a powerful, threeday exhibition held at the European Parliament named "Women Entrepreneurs: Five Pillars of Growth" and was followed by a series of events throughout the year. The campaign met and even exceeded the industry's expectations. It attracted the interest of senior officials; chief among them Vice-President of the Barrosso II Commission Viviane Reding, who was also the champion of the Women on Boards ${ }^{599}$ initiative.

In addition, the issue has appeared to catalyse the formation of a coalition between the industry and the civil society representing women entrepreneurs all over Europe. Seldia found 30 women NGOs and associations to support and participate in the event, which increased the credibility of the initiative.

It was in the course of said event that with 15 of the 30 partaking civil organisations and Seldia, the Women Entrepreneurship Platform was established as an umbrella organisation that has a multitude of aims: From promoting women entrepreneurship to gathering and representing a number of "like-minded organisations" (female entrepreneurship associations) as well as sharing information and best practices. Notably, the WEP is also the first port of call for policymakers and other stakeholders who are willing to press the issue of female entrepreneurship further. ${ }^{600}$

Concrete missions and objectives have been defined by members of the WEP: shortterm aims include the exchange of good practices, information, success stories and case studies. A further short-term objective is the collection of relevant data and statistics

\footnotetext{
${ }^{598}$ European Commission - DG Enterprise and Industry, Evaluation on Policy: 'Promotion of Women Innovators and Entrepreneurs', submitted by the E. E. C. (GHK, Technopolis) within the framework of ENTR/04/093-FC-Lot 1 July 2008, p. 3-4.

599 The "Women on Boards" initiative aimed to achieve gender equality in the top positions of European companies' top positions due to the current under-representation of women executives.

${ }^{600}$ Women Entrepreneurship Platform website, “Objectives” at http://womenentrepreneurshipplatform.eu/ about-us/objectives/ (last visited 17 September 2014)
} 
about women entrepreneurship and self-employment in the EU to support the Platform's advocacy positions. Long-term objectives -besides the promotion of women entrepreneurship- are the development of advocacy positions and funding strategies, according to the WEP website.

With designated staff appointed between spring 2013 and spring 2014, Seldia ${ }^{601}$ has become the managing organisation of the WEP. The Platform itself enjoyed the support of 21 Members of the European Parliament, referred to as the "MEP Champions". MEP Champions have expressed a strong commitment to women entrepreneurship and are the supporters of the national women organisations as well as the WEP. Through the WEP, Seldia has established contacts with the 21 politicians and has easier access to even more policymakers by being the promoter of the issue of women entrepreneurship.

All in all, women entrepreneurship as an advocacy theme has accomplished a number of the key aims of the industry: the plausibility of the cause has contributed to the improvement of the industry's public perception and credibility, built bridges to policymakers, opened doors to politicians, and has led to the establishment of a coalition with civil society as well as the creation of the Women Entrepreneurs' Platform.

The Women Entrepreneurship Platform as Seldia's front group and a seemingly spontaneous grassroots organisation is a novel and innovative element in the industry's EU advocacy. The goals of the WEP were set rather broadly, trying to avoid giving the impression that the Platform serves the self-interest of the industry. The cause of empowering women entrepreneurs in general allows the direct selling industry to promote itself indirectly as the supporter and facilitator of women entrepreneurship. The plausibility of the WEP's mission grants it considerable political attention and backing. Moreover, through the Platform, Seldia can access an increased number of policymakers and attract more political and media attention.

As the voice of women running their own businesses, the WEP also enjoys strong NGO support, which increases the credibility and social respectability of the initiative and, indirectly, that of the entire industry. Participants of the Platform also have the potential to mobilise their respective membership with a view to influencing legislation and drawing public and legislative support for their undertakings.

A prospective challenge that Seldia and its members can face with the WEP and the promotion of women entrepreneurship in particular is that the focus of the discourse may easily be diverted from entrepreneurship to a gender equality discussion that does not serve the industry's interests. This risk is increased by the fact that supporters -be it

601 WEP website, http://womenentrepreneurshipplatform.eu/about-us/supported-by-seldia/ (last visited 17 September 2014) 
MEPs, civil servants or women's rights advocates- are usually women for whom the gender aspect may be a priority.

Conclusively, the women entrepreneurship campaign and the establishment of the WEP can be seen as a public relations technique to influence public policy and public opinion for the moment. It remains to be seen whether the Platform will be useful in actual legislative lobbying or whether it will continue to be a clever PR tool.

\subsection{Evaluation}

The direct selling industry advocacy's actions in the field of entrepreneurship promotion have proven to be smart and assertive PR actions, depicting direct selling corporations as being at the heart of SME development. The European Entrepreneurship policy was thus a good opportunity for the direct selling industry to try and reposition its own image tailored to the contemporary political narrative and to thereby advertise direct selling business opportunities.

The industry's public events purposing to manage and improve the industry image on the other hand have provided European policymakers with an additional platform to promote their own agenda and reinforce uncontroversial messages concerning the importance of entrepreneurship, the development of SMEs or female entrepreneurship, which is why the direct selling industry was exceptionally efficient in finding highprofile politicians to support the issue.

The assessment of various lobbying techniques has shown a high level of creativity on the industry's side: the establishment of a front group promoting the issues of women entrepreneurs and the funding of academic research are the true highlights of this dossier.

Overall, the direct selling industry lobby's actions concerning the promotion of entrepreneurship in Europe have contributed to the image building of both industry and European policymakers. The industry lobby has, however, remained on the safe side in terms of the issues it chose to promote and has thus missed the opportunity to both address current political issues in the framework of entrepreneurship and to achieve substantial legislative goals in bettering the legal environment for SMEs, which would be desirable by direct selling corporations both at European and at national level.

From a societal perspective, the entrepreneurship campaign of the industry raised policymakers' and the general public's awareness of the field as well as of direct selling as an opportunity to make extra income. On the other hand, however, the campaign is geared towards serving the industry's interests in both advertising the industry as well as in creating an opportunity for the industry to build bridges with politicians. 
The promotion of women entrepreneurship in particular may be a positive feature of the industry's PR actions, providing information to and increasing the popularity of female business owners, yet there is a threat that keeping the issue on the political agenda through the recently established front group WEP, will be predominantly used for industry lobbying rather than for aiding women in their business ventures.

A further point of criticism concerns the fact that the direct selling industry lobby has remained superficial and self-interested and has not addressed the politically more relevant -but also more controversial- issue of immigrant entrepreneurs. According to the OECD Entrepreneurship 2020 action plan, migrants are more entrepreneurial than natives and a foreign-born self-employed person who owns a small or medium firm creates between 1.4 and 2.1 additional jobs. ${ }^{602}$ The policy document claims that reaching out to migrants is crucial in Europe. ${ }^{603}$

Network marketing and direct selling appear to be an attractive option for Europe's sharply rising number of immigrants, even for those who are less skilled. Studies suggest that the underlying reasons for immigrants becoming engaged in network marketing is the positive environment, self-efficiency and the desire for opportunity, which, accelerated by human capital, is positively related to financial performance outcomes. ${ }^{604}$ Furthermore, lower qualified migrants, even those who do not speak the host country's language and are at a disadvantage in the employment market, can start their direct selling businesses and operate within their own cultural enclaves in the host country successfully. The observation made by direct selling consultant and former country director of Oriflame Turkey, Hakki Ozmorali, according to which direct selling as a sales method is particularly profitable in collectivist societies where social networks and peer support are strong, seems to provide a further potential explanation for many mostly Asian immigrants' - outstanding accomplishments in direct selling, ${ }^{605}$ and is in conformity with the suggestion that the entrepreneur uses ethnic and family support in the operation of the business even after it is established. ${ }^{606}$

Although statistics in this respect are somewhat scarce, there are some concrete figures that underline the economic potential of direct selling amongst immigrants in Europe. In early 2013, in its $40^{\text {th }}$ year of operation in the UK and Ireland, Amway reported that its salespeople were almost entirely British during its first 35 years. In the spring of

\footnotetext{
${ }^{602}$ OECD, Open for Business; Migrant Entrepreneurship in OECD Countries, OECD Publishing, 2010, http://dx.doi.org/10.1787/9789264095830-en (last visited 17 September 2014)

${ }^{603}$ Entrepreneurship 2020 Action Plan, p. 24.

${ }^{604}$ Fu Dai, A Model of Network Marketing Business Entrepreneurial Performance, 2012, p. 24.

${ }^{605}$ The interview with Mr. Hakki Ozmorali was conducted on 30 September 2013 in Brussels.

${ }^{606}$ Piperopolous, P. G., Entrepreneurship, Innovation and Business Clusters (Gower Publishing Limited, Surrey, England, 2012), p. 90.
} 
2013, 60 per cent were migrants and it is predicted that this number will rise to 90 per cent within the next five years. ${ }^{607}$ Oriflame has also accounted for a growing number of UK consultants originally from Poland, Hungary and Romania, a trend that matches some of Oriflame's top markets. The company first noticed this trend in 2004, after several eastern European countries joined the EU. The cosmetics company now translates materials into Polish and says 45 per cent of its sales force was born outside the UK. ${ }^{608}$

Given the political tensions and controversies around the issue of immigration, it is undoubtedly a more sensitive topic than women entrepreneurship. Nevertheless, the apparent success of immigrant entrepreneurs in direct selling would allow the industry to engage in more substantial and constructive dialogues with policymakers, thereby also serving societal interests.

In addition, another potential critique may concern the lack of legal discourse.In addition to the PR efforts aimed at improving the image of the direct selling industry, legislative lobbying goals in the industry advocacy concerning the promotion of entrepreneurship could (have been) included on two possible terrains.

At the European level it has already been indicated that the industry did not agree with the harmonisation of direct sellers' statuses and nor did a consistent lobbying dossier emerge concerning the regulatory approach towards direct sellers. However, the diversity of Member State legislations governing the establishment, administration and taxation obligations of businesses remains to be a problem for small- and micro businesses.

SMEs' and, potentially, direct selling corporations' interests -as revealed by empirical research into direct selling corporate interest representation (for details, see subsection 7.4.3.2.5.) - may thus call for action in the field of the consolidation of tax rules, i.e. the Commission proposal (COM (2001) 582) regarding the establishment of a common consolidated corporate tax base (CCCTB) to improve the legislative environment of small businesses (direct sellers) especially.

Compliance with tax rules in particular can be challenging for small businesses. Moreover, complex and considerable differences in Member States' tax legislation pose major obstacles for (small) enterprises in doing cross-border business transactions. While the harmonisation of tax laws would probably be next to impossible in the European Union, ${ }^{609}$ the consolidation of the corporate tax rules through the CCCTB could make the EU a more attractive place to invest. Furthermore, the improvement of Euro-

\footnotetext{
607 Jacobs, E., Financial Times, 'Ambitious migrants fuel rise in direct selling', 5 April 2013, http://www.ft.com/intl/cms/s/0/c0176c2e-9dfc-11e2-9ccc-00144feabdc0.html\#axzz2t34mmXAf (last visited 17 September 2014)

${ }^{608}$ Ibid.

${ }^{609}$ Gondor, M., 'A Common Corporate Tax Base in Order To Improve the European SMEs' Business Environment', 14 Juridical Current; Issue 1 (2011), p. 151-158., p. 156.
} 
pean and national fiscal regulations based on the principles of simplification and the reduction of administrative costs would benefit all businesses but especially SMEs which are said to be currently disproportionately affected by regulatory and administrative obligations. $^{610}$

\subsection{Conclusions}

The aim of the present chapter was to explore the direct selling industry's (i.e. Seldia's and Amway's) lobbying actions concerning the promotion of entrepreneurship. Examination of the powerful PR campaigns conducted in an effort to improve the industry image has brought the incompleteness of the dossier to surface: the lack of legislative lobbying to overcome fragmentation and to improve the business environment for SMEs at European and national level.

In the context of the escalated attention turned towards European entrepreneurship policy, Seldia saw a window of opportunity open up and was able to side with European policymakers in the promotion of entrepreneurship as representatives of an industry that is deeply rooted in entrepreneurial values.

Advocating entrepreneurship serves a dual purpose for the industry: on the one hand, it is hoped to increase the number of direct sellers (entrepreneurs) and, on the other hand, it has given way for the industry lobby to tailor the industry's narrative to the contemporary political discourse, thus making the industry more appealing for politicians and the general public.

Still, European policymakers also benefitted from the industry's PR actions, which allowed them to reinforce their own political agenda concerning the promotion of entrepreneurship, strengthening SMEs and, to some extent, even gender issues, through the advancement of women entrepreneurship.

While attempts to improve the distorted industry image are undoubtedly beneficial for the industry itself, the overall assessment of the industry's needs in Europe have proven the Seldia lobby on entrepreneurship to be predominantly driven by self-interest and slightly superficial. It does not address truly substantial issues such as immigrant entrepreneurship or the necessity to improve European and national regulations to simplify and reduce administrative costs and regulatory burden for SMEs, or direct sellers, which would, however, be important from a societal perspective.

${ }^{610}$ Ibid., p. 158. 



\section{Strategies and Techniques of \\ Direct Selling Interest Representation}





\subsection{Introduction}

Following the in-depth description of the direct selling industry's strategic interests, the present chapter assesses the lobbying behaviour of the industry advocacy, directed at achieving a set objectives, from the perspective of political science. To that end, the analysis of the direct selling lobbying dossiers is complemented by an overarching empirical research into direct selling advocacy.

Findings of the legal- and empirical research are placed in the context of various political science disciplines to interpret the motivations, organisational forms and institutional access of the direct selling industry. For that purpose, following the description of the research method in 7.2., section 7.3. will introduce the theoretical framework underlying the current analysis: the public choice theory (7.3.1.), Mancur Olson's theory concerning interest groups' size and collective action, and lastly, the theory of access (7.3.2.) in order to take a close look at the institutional access of the direct selling industry's lobbying actors, checked against the comprehensive model of Pieter Bouwen.

Results of the empirical research conducted with the participation of the two European direct selling trade associations, 11 national direct selling associations and 5 corporate representatives will be presented in section 7.4. and will be discussed in relation to the political sciences paradigms in section 7.5.

More specifically, motivations of the industry advocacy and lobbyism in general are assessed through the public choice theory along the lines of the paradigm laid down by Downs, Tullock, Becker and Lukes. Industry lobbyists as rational actors looking to maximise their benefits are placed in the context of the European Union's pluralistic system of interest representation and are examined relative to the actions of competing interest groups with the help of the previously analysed lobbying dossiers.

In terms of the organisational forms of the direct selling industry lobby, collective action spearheaded by European and national trade associations have been investigated, whereas the individual lobbying of direct selling corporations as well as third party representation have been analysed in the course of the research. Organisational forms and the interrelations of the group's size and lobbying efficacy were studied against the backdrop of Mancur Olson's theoretical foundations.

The third aspect of the current enquiry was the systematic assessment of the industry lobby's approach towards European institutions, which has been carried out and studied against the background of Pieter Bouwen's model or private actors' access to European institutions. For that purpose, patterns of each direct selling advocacy actor's (or group of actors') lobbying behaviour have been indicated and were compared to the aforemen- 
tioned theoretical model, based on which conclusions have been deducted concerning the sector's advocacy.

\subsection{Research Method and Constraints}

The overall objective of the present empirical research is to explore and gain a deeper understanding of the direct selling industry's lobbying behaviour from the perspective of political sciences. To that end, findings of the direct selling industry's four key lobbying dossiers are complemented with an empirical research into the industries' lobbying techniques and the two sets of data together are placed into and examined in light of political theories, in particular the public choice-, the Olsonian group size- and the access theories.

Accordingly, the preparatory groundwork that preceded and served as a basis of the technical enquiry was presented through the introduction of four lobbying dossiers. The first three represented issues of legislative lobbying (the Consumer Rights Directive advocacy [chapter III], the dossier on pyramid regulation [chapter IV] and the examination of industry self-regulation [chapter V]), whereas the fourth case study was conducted on a non-legislative, mainly $\mathrm{PR}$, dossier concerning entrepreneurship promotion.

Enquiry into legislative lobbying dossiers has already brought a number of key technical issues to the surface concerning, for instance, preferred lobbying strategies and the stages of intervention. The assessment of legislative dossiers has revealed that the industry prefers to follow a proactive lobbying strategy, attempting to intervene at the earliest stage of the legislative procedure as possible. This revelation was accompanied by the finding that the industry tends to achieve good results in the pre-Commission phase, although its performance is not always as strong in the post-Commission phase. More specifically, it was discovered that while in both the pyramid scheme- and CRD dossiers the industry was successful in lobbying the Commission, there was a difference in the advocacy efficiency in the post-Commission stage, necessitating a more technical enquiry into this phenomenon.

Moreover, it was also evident from the substantial assessment that, despite the small size and sectorial interests of the lobby group, the direct selling industry still managed to make a relatively considerable impact on European unfair competition law relative to the magnitude of the industry, calling for further investigation into the issue.

The dossiers concerning the promotion of entrepreneurship and self-regulation have also been examined in their merits in previous chapters, but will be looked into from the perspective of political sciences' disciplines too. 
In an effort to gain a comprehensive understanding of the truly technical aspects of direct selling industry lobbying, in addition to the examination of lobbying dossiers all key actors of the direct selling industry have been approached. Both European trade associations' representatives have been contacted, as well as all national direct selling associations and corporate members of the European associations in order to conduct a systematic investigation of interest representation techniques and institutional access of industry lobbyists to key European institutions: the European Commission, the European Parliament, the Council of Ministers and the Court of Justice of the EU.

A total of 10 exploratory interviews have been conducted with various actors of the direct selling industry advocacy as well as other public affairs experts, and 11 national direct selling associations have been analysed based on their voluntary responses to a standardised questionnaire for the purposes of the present research.

All interviews were based on the informed consent of the participants, the transcripts were approved by the interviewees in writing prior to the submission of the thesis and, moreover, full confidentiality and the non-disclosure of the participants' identities and/or their employers was guaranteed, unless the interviewees expressly consented to the disclosure of their identities.

Despite having gained considerable encouragement and support in the course of the 18-month research process from a high number of industry representatives, the sensitivity of the topic itself as well as the fact that the industry advocacy is split in Europe in part impeded the procedure of objective fact-finding.

Political strategies tend to be highly confidential in general, but in the case of the direct selling industry, which is divided into two competing lobby groups, disclosing information about lobbying techniques proved particularly problematic.

Furthermore, due to the fact that the overwhelming majority of interviewees (10 out of 11) are representatives of the direct selling industry, findings of the interviews may, to some degree, be biased, particularly in relation to the more subjective aspects of the research such as the level of difficulty of lobbying for the direct selling industry, what the reasons for the industry split were or whether reuniting the industry is possible. Answers to these questions do depend on the interviewees' and/or their beneficiaries' subjective perception and assessment wherefore the objectivity of these findings may be compromised. In addition, interviewees' strict confidentiality obligations did not always allow interviewees to disclose all available information and has, to some extent, limited the scope of findings of the present research. The vulnerability to bias and subjectivity was attempted to be minimised through both the awareness that interviewees may in fact be giving "politically correct" answers as well as through the consistency of the 
questioning. The (semi-)structured interview scheme facilitated the comparison of responses as well as the organisation and analysis of the data.

All in all, the research does not cover the field of the European direct selling business lobby in its entirety and is not representative from a strict statistical standpoint. However, the conclusions drawn based on the enquiry into the lobbying dossiers have shown considerable overlaps with the outcome of the empirical research, thereby increasing the credibility of the findings.

Interviews with the European trade association representatives have been based on a semi-structured scheme. Unlike in the case of other actors, non-disclosure of identities of DSE's and Seldia's representatives or the associations themselves was not possible, for which reason the interview structure was designed to be less rigid, allowing for more liberty for the interviewees to express themselves in a way that did not violate their own confidentiality obligations towards their respective beneficiaries. The interviews with both European trade associations' representatives have focused on a) the reasons of the industry split, b) the functions each trade association fulfils in terms of advocacy and self-regulation and c) the strategies and targets of lobbying in the European and, recently, national terrains. Interview questions can be found in Annex I of the current study, and the interview transcripts, as approved by the interviewees, are on file with the author.

National member associations of both European trade associations in all European Member States have been contacted and were requested to fill in a standardised questionnaire (to be found in Annex II) concerning the size of their association and the advocacy work they do towards European institutions in terms of conveying national and European interests towards Brussels policymakers -the European Commission, the European Parliament and the Council of Ministers- and their national governments in order to instigate intervention at the Court of Justice of the European Union. Due to the fact that participation in the research was voluntary, it was a little over $40 \%$ of all national associations that returned the questionnaire, resulting in a sample that is not entirely representative. However, for the purposes of the research focusing on the participation and level of activity of DSAs in European interest representation (and not the weight of their position based on the Member State they represent) it was assumed that the national associations are homogenous actors wherefore the $40 \%$ response rate secured a relatively high level of credibility for the research. Furthermore, participants of the research were promised full confidentiality, disallowing the analysis of possible correlations between the DSAs' lobbying activity and the national industry interests/Member States they represent. The returned responses are on file with the author. 
Corporate (direct) members of both Direct Selling Europe and Seldia were approached with a request to conduct standardised interviews as regards the firms' political strategies and advocacy techniques, and, in particular, the way companies obtain information and business intelligence, in what way the corporations' positions are determined and how this is communicated towards European institutions. The standardised questionnaire can be found in Annex III. In order to provide a more comprehensive overview of corporate lobbying, qualitative interviews have been conducted with two representatives of corporations that engage in individual lobbying activities and top executives of two other firms that apply collective interest representation strategies. A fifth corporation that represents the industry's interests in Europe through a consultancy has also undergone the same structured interview procedure to provide insight into its advocacy actions. Overall, three of five representatives individually lobbying for direct selling corporations have been interviewed and, in addition, two other collective lobbying firms agreed to contribute to the research. Similarly to the enquiry into DSAs' advocacy, the participation in this research was voluntary and resulted in a nonrepresentative accidental sample. While the three interviewed individual lobbying firms requested anonymity, the two collective lobbying firms ACN and Kyani permitted the disclosure of their companies' names. The interview transcripts are on file with the author.

The notion of lobbying being rooted in the public choice theory, findings of both the legal- and the empirical enquiry are analysed in this scientific framework. Interest representation as a rational choice of economically rational individual actors with fixed preferences serves as the underlying axiom of the present study. Lobbying -as a semi-hidden means to influence political power- is examined in the context of the Beckerian model of the pluralistic political system, whereby various interest groups compete for public goods in zero-sum political games.

Subject to scrutiny were the various dimensions of political power that are being targeted by the industry lobby and by what methods, in line with Lukes's argumentation in his seminal book Power: A Radical View. More closely, the analysis focuses on the three dimensions of political power: political decision-making, political agenda-setting and the political culture and how the industry lobby attempts to influence these aspects.

Looking at the "critical dimension" of power, political decision-making, it was assessed how competing interest groups' actions influence the outcome of the deliberations and political process that lead to the adoption of a norm by way of reference to the legislative lobbying dossiers. The other two dimensions of the Lukesian concept of political power -agenda-setting and the shaping of politicians' perceptions- were examined on the basis of the case studies presented in the previous chapters. 
The theory of collective action and the group size theory of Mancur Olson provided the subsequent aspect of enquiry - trade associations' advocacy and individual corporate lobbying were assessed in the Olsonian frame of reference. Furthermore, the direct selling industry's lobby groups -as those wanting to maximise their profits- and the result of their negotiations have been assessed from an interest-group organisational perspective, looking at whether the output of the highly influenced political decisions always leads to an optimal outcome or if efficient interest groups have the potential to distort the legislative output.

Lastly, the overall findings of the research have been compared to a comprehensive model of institutional access as established by Pieter Bouwen. It was observed how the direct selling industry's advocacy techniques relate to the overall framework of political and litigation strategies, and to what extent the industry lobby is in compliance with the theory of access and how the advocacy activities of the lobbying actors interrelate.

\subsection{Theoretical Framework}

\subsubsection{The Public Choice Theory and Lobbyism}

Lobbying, or lobbyism, is a conscious strategy of interest groups, as rational actors, to attempt to exert influence upon legislators and to respond to particular legislative contexts and, as such, is best fitted within the public choice discipline's theoretical framework. In a nutshell, the public choice theory sketches 'politics without romance', as Buchanan put it, with all individual actors seeking to maximise their utilities.

The public choice school emerged in the two decades following the Second World War, as a result of dramatic changes in the world's political environment and a major shift towards the abolishment of dictatorships and the establishment of democratic systems, 'a state that public choice is uniquely qualified to analyse'. ${ }^{611}$ A relatively new paradigm in social sciences, public choice is 'an avenue through which an illusory set of notions about the functioning of governments and the behaviour of persons who govern is replaced by a set of notions that embody more scepticism about what governments can do and what governments will do, notions that are surely more consistent with the political reality ${ }^{3}$

\footnotetext{
${ }^{611}$ Rowley, C. K. and Schneider, F. (Eds.), The Encyclopedia of Public Choice (Kluwer Academic Publishers, Dordrecht, 2004), xiv.

${ }^{612}$ Buchanan, J. M., The Collected Works of James M. Buchanan in 20 vls. (Liberty Fund Inc., US, 1999) Volume I., p. 46.
} 
Seminal contributions of the theory include Anthony Downs's The Economic Theory of Political Action in a Democracy (1957); James Buchanan and Gordon Tullock's coauthored The Calculus of Consent: Logical Foundations of Constitutional Democracy (1962), a defining work of the public choice school which is essentially a positiveeconomic analysis of the development of a constitutional democracy in the context of consent; and, thirdly, Mancur Olson's contributions (e.g. The Logic of Collective Action: Public Goods and the Theory of Groups, 1965) have extensively dealt with lobbying groups and their role in shaping policy outcome.

An interdisciplinary approach, the public choice theory refers to 'the use of economic tools to deal with traditional problems of political science ${ }^{\prime 613}$ and is, in other words, 'the economic approach to politics' ${ }^{\prime 14}$. This theory is a somewhat conservative approach to politics ${ }^{615}$ and represents methodological individualism in its mode of analysis. In contrast to holistic approaches, the basic units of analysis are the individual actors who are pursuing their utility maximisation subject to the institutional and budgetary constraints that confront them. ${ }^{616}$ Hence, the discipline of public choice assumes that individual actors have fixed, transitive and exogenously driven preferences. Public choice states that individual actors calculate the expected utility of alternative courses of action and, based on a rational choice, select the action that is likely to maximise their individual profit - in stark contrast to theories that suggest that individuals follow social norms and/or engage in truth-seeking deliberation and eventually accept the power of the "better argument" ${ }^{617}$

Applying the economic theory to non-market political decision making, Downs set up the so-called "self-interest axiom", that is, the view that political behaviour is 'directed primarily toward selfish ends'. Furthermore, and in line with this theoretical foundation, also politicians '....act solely in order to attain the income, prestige, and power which come from being in office... [They] never seek office as a means of carrying out particular policies; their only goal is to reap the rewards of holding office per se. They treat policies purely as a means to the attainment of their private ends.' ${ }^{618}$

\footnotetext{
${ }^{613}$ Tullock, G., 'Public Choice' in Durlauf, S. N. and Blume, L. E. (Eds.), The New Palgrave Dictionary of Economics, Second Edition, (Palgrave Macmillan, Basingstoke, Hampshire New York, 2008) Abstract

${ }^{614}$ See Green, D. and Shapiro, I., Pathologies of Rational Choice Theory: A Critique of Applications in Political Science, (Yale University Press, New Hampshire, 1994), p. xi)

${ }^{615}$ Weschler, L. F., 'Public Choice: Methodological Individualism in Politics', 42 Public Administration Review, No. 3 (May- June 1982), p. 288-294 , p. 288.

${ }^{616}$ Hill, J. P., 'Public Choice - A Review', 34 Faith \& Economics (1999) p. 1-10., p. 1.

${ }^{617}$ Pollack, M. A., 'Rational Choice and EU Politics' in Jorgensen, K., Pollack, M. and Rosamond B. (eds.) Handbook of European Union Politics (p. 31-57) (Sage Publications Ltd., London, 2006) p. 32.

${ }^{618}$ Downs, A., An Economic Theory of Democracy (Harper, New York, 1957), p. 28.
} 
Lobbyism is anchored in the scientific discipline of public choice ${ }^{619}$ and can be defined as an attempt of advocacy groups to influence governments and political decisions directly or indirectly to implement policies that would benefit them. ${ }^{620}$ Where an advocacy group will deem action necessary: '... they may seek to change the nature of the decisions that are taken so that they reflect or at least fail to challenge their own interests.' ${ }^{621}$ To that end, and in an effort to maximise their profit in the political arena, interest groups will hire professional lobbyists to negotiate with regulators and policymakers on their behalf. ${ }^{622}$

The concept of rent-seeking, 'the use of resources in lobbying and other activities directed at securing protective legislation' ${ }^{623}$ was introduced by Tullock. ${ }^{624}$ Government restrictions may create rents for which actors compete, for example through lobbying European institutions. ${ }^{625}$ The thus emerging distortions in policy outcomes result in three types of costs, according to Buchanan and Tullock. ${ }^{626}$ Besides the dead-weight loss that occurs when resources are shifted into or out of an affected policy, costs may also occur from lobbying efforts aimed at blocking or engaging policies and/or, from direct engagement in politics to access decision-making power.

Accordingly, placed into the comprehensive framework of political decision making as defined by the three-dimensional theory of Lukes on power, ${ }^{627}$ it was found that lobbyists will attempt to impact all aspects of power. ${ }^{628}$ The first face of power involves a focus on behaviour in the making of decisions on issues over which there is an observa-

\footnotetext{
619 Svendsen, T. G., 'Lobbyism and Social Capital in the EU', 23 April 2007, ResearchGate, www.researchgate.net, p. 2. (last visited: 20 April 2015)

${ }^{620}$ See Svendsen, G. T., 21 Environmental Policy and Governance, Issue 2 (2011), p. 131-142, p. 136 as well as Wikipedia's definition of Public Choice at http://en.wikipedia.org/wiki/Public_choice (last visited: 20 April 2015)

${ }^{621}$ Gouldson, A. and Murphy, J., Regulatory Realities: The Implementation and Impact of Industrial Environmental Regulation (Earthscan Publications, London, UK, 1998) p. 9.

${ }^{622}$ See Svendsen, G. T., 'Evaluating and Regulating the Impacts of Lobbying in the EU? The Case Study of Green Industries', 21 Environmental Policy and Governance, Issue 2 (2011), p. 131-142., p. 132.

${ }^{623}$ McKenzie, R. and Tullock, G., The New World of Economics: Explorations into the Human Experience (R.D. Irwin, Homewood, Illinois, 1981); McChesney, F. S., 'Rent Seeking and Rent Extraction', in William,W. F. Shughart II and Razzolini, L. (eds.), The Elgar Companion to Public Choice (Edward Elgar, Cheltenham, UK, and Northampton, Massachusetts, USA, 2001), 379-395. as cited by Nielsen, J. F. and Svendsen, G. T., 'EU Lobbying and Anti-Dumping Policy', 46 Journal of World Trade, No. 1 (2012), p. 187-212.

${ }^{624}$ Tullock, G., 'The Welfare Costs of Tariffs, Monopolies, and Theft', 5 Western Economic Journal (1967), p. 224-232.

${ }^{625}$ Nielsen, J. F. and Svendsen, G. T., 'EU Lobbying and Anti-Dumping Policy', 46 Journal of World Trade, No. 1 (2012), p. 187-212., p. 190-191

${ }^{626}$ Buchanan J. M. and Tullock G., The Calculus of Consent (Ann Arbor: University of Michigan Press, 1962)

${ }^{627}$ Lukes, S., Power: A Radical View (Macmillan Publishing, Basingstoke, 1974)

${ }^{628}$ See Svendsen, G. T., 'Evaluating and Regulating the Impacts of Lobbying in the EU? The Case Study of Green Industries', 21 Environmental Policy and Governance, Issue 2 (2011), p. 131-142.
} 
ble conflict of (subjective) interests, seen as expressing policy preferences, revealed by political participation'. ${ }^{629}$ The second dimension concerns actions and inactions which shape the agenda-setting process, whereas the third face of power takes the process of non-decision a step further and points out the potential power of actors, in particular the State, to shape people's perceptions and interests through the operation of an ideological hegemony. ${ }^{630}$ In other words, lobbyists will try to a) participate in decision making, b) set the political agenda and c) will shape policymakers perception to influence the legislative- and policy output to maximise their beneficiaries' profit ${ }^{631}$ and do not try to enhance "the public good" through deliberation as other political theories would perhaps suggest. Resources are directed from production to rent-seeking, and thus the state is seen to be pushed and pulled by lobby groups that are more interested in redistribution and the advancement of their own interests than in the overall economic growth in society. ${ }^{632}$ As a result of advocacy groups' aspirations to shape political decisions and/or define the political agenda, it is unlikely that the decisions taken will lead to the optimal outcome. Thus, lobbying holds the potential to distort macroeconomic decisions. ${ }^{633}$

Developed by Gary Becker, ${ }^{634}$ the model of political competition among pressure groups was inspired by the "economic approach" to politics as represented by Bentley, ${ }^{635}$ Stigler, ${ }^{636}$ Peltzman ${ }^{637}$ and Posner ${ }^{638}$ as well as the subsequent literature on pluralistic society by Truman, ${ }^{639}$ for example. According to Becker, it is the competition among pressure groups for political influence that determines the equilibrium structure of taxes, subsidies and other political favours whereby politicians and political decision makers act as mere agents. The government budget equation implies that change in the influence of a pressure group impacting its subsidies and taxes will inevitably affect

\footnotetext{
${ }^{629}$ Lukes, S., Power: A Radical View (Macmillan Publishing, Basingstoke, 1974), p. 15, Italics in original

${ }^{630}$ Lukes, S., Power: A Radical View (Macmillan Publishing, Basingstoke, 1974), p. 18-20.

${ }^{631}$ Svendsen, G. T., 'Evaluating and Regulating the Impacts of Lobbying in the EU? The Case Study of Green Industries', p. 132.

${ }^{632}$ Nielsen, J. F. and Svendsen, G. T., 'EU Lobbying and Anti-Dumping Policy', 46 Journal of World Trade, no. 1 (2012), p. 187-212, p. 191.

${ }^{633}$ Svendsen, G. T., 21 Environmental Policy and Governance, Issue 2 (2011), p. 131-142., p. 132.

${ }^{634}$ Becker, G., 'Competition Among Pressure Groups', Vol. XCVIII The Quarterly Journal of Economics, No. 3 (1983), p. 371- 400.

${ }^{635}$ Bentley, A. F., The Process of Government (University of Chicago Press, Chicago, IL, 1908)

${ }^{636}$ Stigler, G. J., The Citizen and the State (University of Chicago Press, Chicago, Il., 1975)

${ }^{637}$ Peltzman, S., 'Toward a More General Theory of Regulation' 19 Journal of Law and Economics, No. 2 (1976), p. 211-240.

${ }^{638}$ Posner, R. A., 'Theories of Economic Regulation', 5 Bell Journal of Economics and Management Science, No. 2 (1974), p. 335-358.

${ }^{639}$ Truman, D. B., The Governmental Process, $2^{\text {nd }}$ edition (Knopf, New York, NY, 1971)
} 
other groups' taxes and subsidies and thus the influence thereof as well. Becker therefore concludes that groups do not entirely win or lose the competition for political influence, in contrast to the "all-or-nothing" approach of formal models of political behaviour assuming that the "majority" clearly wins over the "minority". ${ }^{640}$

In this model, groups compete for the increase of welfare with the use of taxes, subsidies, regulations and other political instruments within the framework of rules (such as political constitutions) that translate expenditures on political pressure into political influence and access to political favours. ${ }^{641}$ Influence groups within any political system, be it a democracy or dictatorship, will attempt to maximise their welfare and exert pressure on policymakers to decrease their taxes or increase subsidies, although the influence of particular pressure groups may be sensitive to the political system's idiosyncrasies. ${ }^{642}$

Competition amongst the pressure groups is a zero-sum political game whereby the efficiency of an influence group is relative to the efficiency of another group. ${ }^{643}$ The political equilibrium depends on the efficiency of each group in producing pressure, the effect of additional pressure, the number of group members and the deadweight costs of taxes and subsidies. ${ }^{644}$

Looking at deadweight costs and redistribution, Becker found that an increase in deadweight cost reduces the equilibrium subsidy. Because deadweight costs stimulate pressure by taxpayers but demotivate pressure by recipients, taxpayers have an "intrinsic" advantage in influencing political outcomes. ${ }^{645}$ Secondly, this also implies the "tyranny of the status quo" meaning that the political sector would tend to not interfere with the private distribution of income even if the groups that are gaining from interference are better organised politically than those losing out. ${ }^{646}$ (This is however not the same as laissez faire because the political sector would protect against shocks in the private sector.)

Political protection against changes in the private sector will likely be incomplete and temporary - incomplete because with the degree of protection the marginal deadweight cost rises and temporary because supply (and demand) becomes more elastic as some specific investments depreciate over time. Conclusively, a possible explana-

\footnotetext{
${ }^{640}$ Becker, G., 'Competition Among Pressure Groups', p. 372-373.

${ }^{641}$ Ibid. p. 373-374.

${ }^{642}$ Ibid. p. 375.

${ }^{643}$ Ibid. p. 380.

${ }^{644}$ Ibid. p. 395.

${ }^{645}$ Ibid. p. 382.

${ }^{646}$ Ibid. p. 382.
} 
tion of periodic efforts at deregulation is that deadweight costs rise as the duration of regulation increases. ${ }^{647}$

Criticism of the public choice theory is multifold. Utilitarianism -the complete ignorance of community values, social norms and team spirit in the course of political activity- was one of the main points of reproof brought forward in connection with this theory by Kelman. He argued that the aforementioned scientific approach is not applicable to the political arena as individuals do not necessarily act as they would in the market. Furthermore, argued Kelman, it may not be the best and most realistic way to perceive individuals as isolated units. ${ }^{648}$

Nobel-prize winning Amartya Sen -who himself has also contributed to the public choice literature- has also heavily criticised the absurdity of the approach and in particular the idea that all human behaviour is fundamentally based on rational choice. ${ }^{649}$

Another dimension of critique is related to the methodology of rational choice. In their book, Pathologies of Rational Choice, Green and Shapiro question the substantiality of the theory's contributions and claim that 'rational choice scholarship has yet to get off the ground as a rigorous empirical enterprise ${ }^{650}$ and the reasons why it has not done so are systematic: applications are "theory driven" rather than "problem driven."

\subsubsection{Group Size Theory and Collective Action}

Organisations and groups are implicitly assumed to exist because of the common interest of their members - and in this frame of reference the theory of collective action focuses on organisations that are expected to further the common interests of their members. ${ }^{61}$ While individual interests can be best pursued individually, rational lobby groups are oriented towards the representation of common interests and the redistribution of the collective wealth or "collective good" generated by society to the members of the respective group. Pressure groups will not strive to promote interests of society as a whole but will rather attempt to maximise their share of the income pie.

\footnotetext{
${ }^{647}$ Ibid. p. 383.

${ }^{648}$ Kelman, S., 'Public Choice’ and Public Spirit.' 87 The Public Interest (1987), p. 80-94. As cited by Svendsen, G. T.: Evaluating and Regulating the Impacts of Lobbying in the EU? The Case Study of Green Industries, p. 132.

649 Sen, A., 'Rational Fools, a critique of the behavioural foundations of economic theory', 6 Philosophy and Public Affairs, No.4(1977),p.317-344.

${ }^{650}$ Green, D. P. and Shapiro, I., Pathologies of Rational Choice Theory: A Critique of Applications in Political Science (Yale University Press, New Haven, 1994), p. 7.

${ }^{651}$ Olson, M., The Logic of Collective Action: Public Goods and the Theory of Groups (Harvard University Press, Cambridge, MA, 1965) p. 6-7.
} 
Challenging the traditional view that groups are voluntary organisations furthering their common interests, Olson found that it may be easier for small groups with concentrated interests to carry out successful lobbying than for a more sizeable group with dispersed interests. Olson contradicts the idea that groups will act in their self-interest [which] follows logically from the premise of rational and self-interested behaviour.' ${ }^{652}$ This means that based on the foundations of rational and self-interested behaviour, members will only act in the shared objectives of the group if there is sufficient motivation for the individual to do so. Unless individual members are sufficiently motivated, they will not work towards the shared objectives of the group.

The lack of selective incentive, says Olson, will create the "free rider" problem - the emergence of individual actors who do not contribute to the shared objectives of the group, but who nevertheless enjoy the results of collective action. The theory implies that the larger the group's size, the more free riders appear, mostly because of the misalignment of interests among the group members and the share of average benefit to the members in a large group. It follows from the above that an efficient and successful interest group will be smaller in size with more concentrated interests, securing a positive gain for its members which allows for the creation of an average level of benefits that exceed the costs of group action.

The five basic conditions for the formulation and success of an interest group, according to Olson, are the following:

1. Positive gains from lobbying

2. Existence of selective incentives

3. Exclusive goods (i.e. perfect market information on the specific good) that create negative and/or positive externalities

4. Homogeneity of the group members/ alignment of interests

5. Existence of a property rights regime or the low cost of bargaining for collective action. ${ }^{653}$

In summary, the small group of a limited number of actors is paradoxically the more successful political actor, due to the fact that the smaller group with more concentrated interests offers more individual advantage to its members and thus encourages individual participation more than groups larger in size. This Olsonian finding also challenges

\footnotetext{
${ }^{652}$ Olson, M., The Logic of Collective Action: Public Goods and the Theory of Groups (Harvard University Press, Cambridge, MA, 1965) p. 1.

${ }^{653}$ Olson, M., The Rise and Fall of Nations (Yale University Press, 1982) as cited by Babacan, M., 'The Nature of Lobbying and Regulation in Turkey', 1 Afro Eurasian Studies, Issue 1 (2012), p. 173-194., p. 179.
} 
the classic pluralistic theory that interest groups have an equal chance to participate in the political pressure system, thus also questioning whether the free competition of interest groups prevents undue influence of certain advocacy groups.

In a society that is stable over a longer period of time, the development and accumulation of interest groups slows down economic growth, argued Olson in a later book entitled The Rise and Decline of Nations (1982). Studying the patterns of growth of industrialised democracies, and in particular the stagnation of the United Kingdom in contrast to the significant economic growth of post-World War II Germany and Japan (amongst others), Olson has found that the key to understanding these phenomena lies in the power of special interest groups. Olson namely explained the economic miracle in post-war Germany and Japan with the lack of interest groups - when the traditional societal fabric is destroyed by a totalitarian government, a revolution or a defeat in war and a stable legal order is put in place, that society will grow if there is no substantial redistribution to prevent optimal investments. On the other hand, in a society that enjoys long-standing stability more and more interest groups form that attempt to secure themselves power and command over resources through favourable regulation, restrictions of trade and tariffs or subsidies which, however, slow down the growth of society. Economic sclerosis or decline is thus linked to the growth of interest groups and thus the complexity and size of the political sphere and a paralyzing decision-making process that is incapable of rapid response, adjustment and growth. ${ }^{654}$

\subsubsection{The Access Theory}

Economic studies of interest groups focus on two key aspects: utility maximisation and methodological individualism. The Chicago version of the modern development of public choice theory, the Chicago Political Economy (CPE), analyses government from the perspective of price theory and positive economics. According to this theory, 'the State is a mechanism that is used by rational agents to redistribute wealth. Wealth transfers are the essence of regulatory and governmental behaviour in this approach.' ${ }^{655}$

The Chicago Political Economy literature was what inspired one of the most prevalent scientific approaches to European interest groups, the theory of exchange. The exchange model is based on the simple theory of the exchange of resources between actors and thus conceptualises advocacy actions as the provision of goods (mainly in-

\footnotetext{
${ }^{654}$ Behrman, J. R., 'The Rise and Fall of Nations: Economic Growth, Stagflation and Social Rigidities by Mancur Olson', 9 Population and Development Review, No. 2 (June 1983), p. 377-379., p. 377.

${ }^{655}$ Rowley, C. K. and Schneider, F. (Eds.), The Encyclopedia of Public Choice (Kluwer Academic Publishers, Dordrecht, 2004), Vol. 2., p. 74.
} 
formation) in turn for access to political institutions and decision makers. According to this model, 'shifts in positions are assumed to be the result of binding bilateral deals between pairs of actors over pairs of issues.' ${ }^{656}$ Said deals produce gains for the parties directly involved, and may produce gains or losses for those actors who do not have direct involvement in the bargains. ${ }^{657}$

Exchange theories ${ }^{658}$ suggest that European interest mediation can be described as a series of inter-organisational exchanges between public authorities and business interests. ${ }^{69}$ Developing the exchange theory a step further, Aldrich and Pfeffer ${ }^{660}$ observed that, as organisations are not internally self-sufficient, they require resources from their environment and therefore have to interact with other organisations in order to obtain the resources they need. ${ }^{661}$

Based on these foundations, it was Pieter Bouwen who set up a comprehensive system modelling the interdependence where business interests and public actors rely on each other in the access of resources ${ }^{662}$ and proposed a theoretical framework to explain the access of different organisational forms of business interest representation (companies, associations and consultants) to the European Commission, the European Parliament and the Council. The degree of access to these key European institutions is explained in terms of theory of supply and demand of access goods. ${ }^{663}$

From the perspective of the private actors, a key to access and influence European Union decision making processes is information and expertise, ${ }^{664}{ }^{665}$ that is the provision of "access goods". Access goods, according to Bouwen, are necessary for the functioning of the European institutions. There are three types of access goods identified by

\footnotetext{
${ }^{656}$ Arregui, J., Stokman, F., and Thomson, R., 'Bargaining in the European Union and Shifts in Actors' Policy Positions', 5 European Union Politic, Issue 1 (2004), p. 47-72., p. 49.

${ }^{657} \mathrm{Ibid}$.

${ }^{658}$ Greenwood, J., Grote J.R., Ronit K. (eds.), Organised interests and the European Community (Sage Communications, London, 1992); Buholzer, R., Legislatives Lobbying in der Europäischen Union, Ein Konzept für Interessengruppen, (Verlag Paul Haupt, Bern-Stuttgart-Wien, 1998); Pappi, F. U., and C. H. C. A. Henning, 'The organization of influence on the EC's common agricultural policy: A network approach', 36 European Journal of Political Research (1999), p. 257-281.

${ }^{659}$ The theory of inter-organisational relationships itself has been developed in the 1960s.

${ }^{660}$ Aldrich H.E. and Pfeffer J., 'Environments of Organisations', 2 Annual Review of Sociology, (Volume publication date August 1976), p. 79-105., p. 83.

${ }^{661}$ Pfeffer J. and Salancik G. R., The External Control of Organisations, A Resource Dependence Perspective, (Harper and Row, New York,1978), p. 258.

${ }^{662}$ Bouwen P., 'Corporate lobbying in the European Union: towards a theory of access', 9 Journal of European Public Policy, Issue 3 (2002), p. 365-390.

${ }^{663}$ Bouwen P., A Comparative Study of Business Lobbying in the European Parliament, the European Commission and the Council of Ministers, MPIfG Discussion Paper 02/7, ISSN 0944-2073, November 2002, p. 2. ${ }^{664}$ Ibid., p. 2.

${ }^{665}$ Gueguen, European Lobbying (Europolitics, Brussels, 2007), p. 70.
} 
this theory with one characteristic in common: information. "Encompassing European Interest" concerns the needs and interests of the sector - controlled by the European trade associations; "Expert Knowledge" can be defined as technical expertise provided by private actors, such as businesses, needed in order to understand the market; and, finally, information on the "Encompassing National Interest" relates to the aggregated needs and interests of a sector in a domestic market and is usually provided by the national trade associations. ${ }^{666}$ The "encompassingness" of interest groups and their representativeness are positively correlated. ${ }^{667}$

Access goods also play a key role in the legitimacy of the European governance, ${ }^{668}$ says Bouwen. ${ }^{669}$ Access goods influence the overall legitimacy of the European Union: Encompassing access goods enhance the input legitimacy of the EU institutions, because they give information about encompassing and representative interests and thereby provide for a more democratic decision-making process allowing the participation of citizens and interest groups. Expert Knowledge on the other hand concerns output legitimacy - the EU's general efficiency and effectiveness in dealing with problems. ${ }^{670}$

The supply of access goods is crucial for private actors in establishing an exchange relation with the targeted European institution. However, various private interests have various capacities to provide access goods and the organisational form of business interest representation is a crucial variable for determining the kind of access goods that can be provided. ${ }^{671}$ The three main organisational forms are individual firms (at the national or EU level); associations (at the national or EU level) and consultants (at the national or EU level).

Individual firms differ in their size, and, consequently, in their capacities to provide access goods. Due to the fact that large firms are directly active in the market and have a hierarchical decision-making structure, they are capable of providing Expert Knowledge to European institutions in an efficient manner. Large firms' strategies can be European,

\footnotetext{
${ }^{666}$ Bouwen P., A Comparative Study of Business Lobbying in the European Parliament, the European Commission and the Council of Ministers, MPIfG Discussion Paper 02/7, ISSN 0944-2073, November 2002, p. 8.

${ }^{667}$ Salisbury, R., 'Why No Corporatism in America?' in Trends Towards Corporatist Intermediation, Schmitter, P., C., and Lehmbruch, G., (eds.), (Sage Publishing, London, 1979) p. 213-230., p. 222.

${ }^{668}$ Bouwen follows Scharpf's two-dimensional concept of the European legitimacy and makes a distinction between input-oriented and output-oriented legitimacy. On the input side democratic legitimacy needs mechanisms and procedures that connect political decisions to preferences of citizens and interest groups, whereas output legitimacy produces effective outcomes without which democracy would only be an "empty ritual”. Scharpf, F., Governing in Europe: effective and democratic? (Oxford University Press, Oxford, 1999), p. 268. ${ }^{669}$ Ibid., p. 371.

${ }^{670}$ Ibid., p. 371.

${ }^{671}$ Bouwen P., A Comparative Study of Business Lobbying in the European Parliament, the European Commission and the Council of Ministers, MPIfG Discussion Paper 02/7, ISSN 0944-2073, November 2002, p. 10.
} 
regional or national. Those with a focus on national strategies can be "national champions" and are in a position to provide information on the Domestic Encompassing Interest - although the "encompassingness" of the information will necessarily be limited. Firms with European strategies will have only limited capacities to supply policy makers with information on the Encompassing European Interest, given that individual firms are motivated to articulate their individual interests. ${ }^{672}$

Associations -be it at national or EU level- are specialised in building the consensus positions of their members. European associations that aggregate the interests of their national association members (that encompass the positions of their member companies) can provide good quality information about the European Encompassing Interest. However, the complex process of the associations' consultative mechanisms has a negative impact on the efficiency of the provision of access goods. Similarly, national associations are in a position to provide good quality information on the Domestic Encompassing Interest, but less effectively. ${ }^{673}$

On the other hand, associations are not as good as individual companies in providing Expert Knowledge because they have less resources and deal with a wider range of issues ${ }^{674}$ Furthermore, it is a common belief that trade association officials in Brussels are "industrial civil servants" who lack the expertise needed to inform policy formulation, say Greenwood and Webster. ${ }^{675}$

Consultants (at the national or EU level) have a very limited capacity to provide access goods, asserts Bouwen. Due to the fact that consultants do not represent their own interests, they cannot provide the two encompassing access goods and can only provide Expert Knowledge in the event that the consultancy is specialised, which, however, is only rarely the case in Brussels.

The third main aspect of European business lobbying of Bouwen's theory would be the analysis of demand for access goods. Each European institution demands a different type of access good, depending on the respective institution's role in the legislative process and the timing of their intervention. ${ }^{676}$

The European Parliament has both supranational and intergovernmental features: while political groups are supranational, nationality remains an important cleavage

\footnotetext{
${ }^{672}$ Ibid., p. 11.

${ }^{673}$ Ibid., p. 12.

${ }^{674}$ Ibid., p. 11.

${ }^{675}$ Greenwood, J. and Webster, R., 'Are EU Business Associations Governable?', 4 European Integration Online Papers, Number 3 (2000), p. 5.

${ }^{676}$ Bouwen, P., A Comparative Study of Business Lobbying in the European Parliament, the European Commission and the Council of Ministers, MPIfG Discussion Paper 02/7, ISSN 0944-2073, November 2002, p. 13.
} 
within the assembly. ${ }^{677}$ The European Parliament's role in the legislative procedure has increased significantly and has obtained important powers, alongside with the Council, in the co-decision procedure. It is the European Parliament that reviews the Commission's legislative proposals and needs information that allows for the assessment of the proposals from a European perspective. Therefore, some basic Expert Knowledge is indispensable, but it is far less needed for the Parliament's decision making as is information on the European Encompassing Interest, which is also the critical resource of this institution. Thirdly, because MEPs are still elected nationally, they need information on their electorate at home in order to be re-elected; for which reason MEPs need information about the Domestic Encompassing Interest. ${ }^{678}$

The most supranational institution, the European Commission, requires information on the European Encompassing Interest in order to be able to identify common European interests. Furthermore, the Commission has the sole right to initiate legislation in the EU and is thus responsible for drafting legislative proposals. Drafting legislation requires significant expertise wherefore the Commission demands Expert Knowledge from private actors. In the agenda-setting and policy developmental phase, the Commission is not interested in information on the Domestic Encompassing Interest also because the Commission is geared towards promoting European interest without identifying national interests. It may, however, be interested in the Domestic Encompassing Interest on an ad hoc basis, when, for instance, a legislative proposal needs to be amended to achieve a compromise in the Council and the Parliament. ${ }^{679}$

In contrast to the European Commission, the Council is the most intergovernmental organisation in the EU legislative procedure. The Council is the forum for reconciling the distinctive purposes and powers of the Member States. Because the national interests still prevail in the Council, this institution and the Member States require information about the Domestic Encompassing Interests, which is thus the Council's critical access good. Although the Council is predominantly intergovernmental, its Secretariat and Presidency embody a sense of collective purpose, which explains why the Council has an interest in information about the Encompassing European Interest. Thirdly, as the Council shares increasing legislative power with the European Parliament and can influence the final shape of the legislative proposal -when it has already reached a very high level of technicality and further expert knowledge may not be needed- information that

\footnotetext{
${ }^{677}$ Kreppel, A. and Tsebelis, G., 'Coalition Formation in the European Parliament', 32 Comparative Political Studies (1999), p. 936-966.

${ }^{678}$ Bouwen P., A Comparative Study of Business Lobbying in the European Parliament, the European Commission and the Council of Ministers, MPIfG Discussion Paper 02/7, ISSN 0944-2073, November 2002, p. 13-14. ${ }^{679}$ Ibid., p. 15.
} 
can facilitate the bargaining process among Member States can be highly useful for the Council. ${ }^{680}$

Table 1: Demand for Access Goods by Bouwen ${ }^{681}$

Critical Resource Ranking of Dependencies

\begin{tabular}{ll}
\hline European Parliament & IEEI $>$ IDEI $>$ EK \\
European Commission & EK $>$ IEEI $>$ IDEI \\
Council of Ministers & IDEI $>$ IEEI $>$ EK
\end{tabular}

$\mathrm{EK}=$ Expert Knowledge;

IDEI=Information about the Domestic Encompassing Interests;

IEEI=Information about the European Encompassing Interests.

Table 2: Overview of Generated Hypotheses by Bouwen ${ }^{682}$

\begin{tabular}{ll}
\hline 1. Access to the European Parliament & EA $>N A>I F$ \\
2. Access to the European Commission & IF $>$ EA $>N A$ \\
3. Access to the Council of Ministers & $\mathrm{NA}^{*}>\mathrm{EA}>\mathrm{IF}$
\end{tabular}

${ }^{*}$ National Associations and National Champions

EA=European Associations

NA=National Associations

IF=Large Individual Firms

The empirical testing and comparative institutional analysis has suggested that national associations have proven to have a proportionally higher degree of access to the Council (43\%) than to the Parliament (37\%) and the Commission (21\%). It is unsurprising that the Council is the institution to which national associations have the highest degree of access, as it is these associations that provide information on the Domestic Encompassing Interest to the intergovernmental institution.

European associations have a higher degree of access to the European Parliament (38\%) and the European Commission (43\%) than to the Council of Ministers (11\%). The European associations' high degree of access to the European Commission suggests that the Commission is in high demand of information on the Encompassing European Interests in addition to Expert Knowledge. ${ }^{683}$

\footnotetext{
${ }^{680}$ Ibid., p. $15-16$

${ }^{681}$ Bouwen, P., 'Exchanging access goods for access: A comparative study of business lobbying in the European Union institutions', 43 European Journal of Political Research, Issue 3, (2004), p, 337-369., p. 345.

${ }^{682}$ Ibid., p. 348.

${ }^{683}$ Bouwen, P., A Comparative Study of Business Lobbying in the European Parliament, the European Commission and the Council of Ministers, MPIfG Discussion Paper 02/7, ISSN 0944-2073, November 2002, p. 29.
} 
Individual firms have a higher degree of access to the European Commission (34\%) and the Council (37\%) than to the European Parliament (20\%). It is mostly the nonnational firms that have access to the Commission - as they are the ones providing Expert Knowledge to the Commission - and the "national champions" that frequently interact with the Council, supplying them with information on the aggregated national interest. ${ }^{684}$

In the course of the empirical research, it has been proven that Consultants have a relatively low degree of access (Parliament $=5 \%$, Commission $=2 \%$, Council $=9 \%$ ). ${ }^{685}$

\section{Bouwen's Relative Access Model EP, EC, CM Compared}

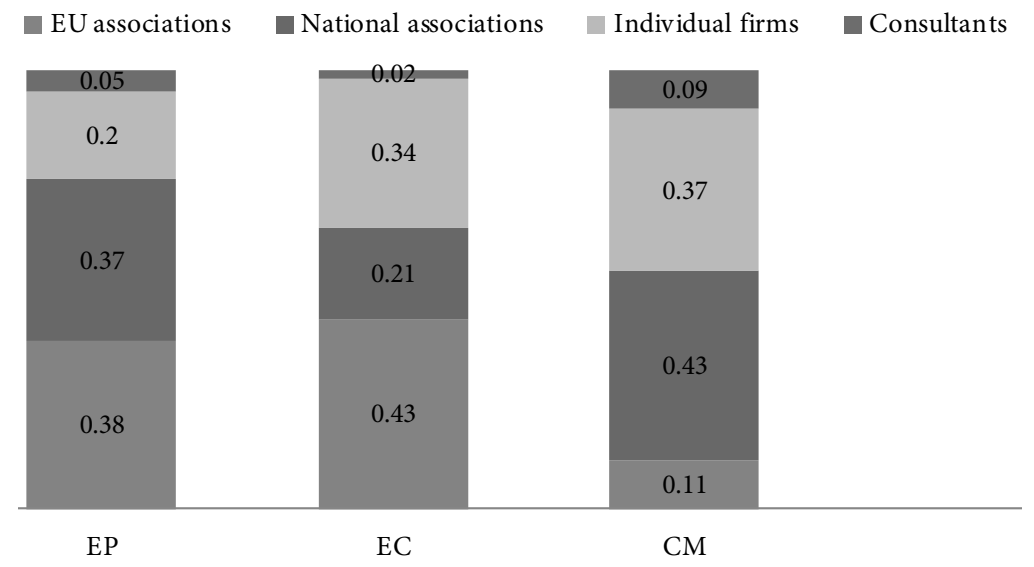

A complementary means to political strategies to influence public policy and to shape regulation is strategic litigation. Unlike traditional lobbying where the successful output requires the persuasion of the majority of the legislature, litigation may be an appealing option for minority interests to challenge rules. The Court of Justice of the European Union is the venue in the EU that has institutionalised profound changes in European law and has therefore become a target of interest groups seeking policy changes. ${ }^{686}$

\footnotetext{
${ }^{684}$ Ibid., p. 29.

${ }^{685}$ Ibid., p. 30.

${ }^{686}$ McCown, M., 'Interest Groups and the European Court of Justice', in: Coen, D. and Richardson, J. (eds.) Lobbying the European Union: Institutions, Actors, and Issues, chapter 5, (Oxford University Press, Oxford, 2009)
} 
Indeed, institutionalised as precedents, rulings of the CJEU have served as basis of changes of EU law, including the "constitutionalisation" of the Treaties, ${ }^{687}$ trade liberalisation, ${ }^{688}$ evolution of the separation of powers rules ${ }^{689}$ and the creation of new policy areas. $^{690}$

In addition to the interpretation of EU law to ensure it is applied in the same way in all EU Member States, or the settlement of legal disputes between EU governments and EU institutions, the Court of Justice also deals with cases brought by individuals, companies or organisations. It was the declaration in Van Gend en Loos (ECJ 26/62) that EU law applies to individuals as well as Member States that opened the door to private interest litigation. ${ }^{691}$

The incentive of private actors to litigate depends on both the institutional environment as well as the available resources and organisational form of private interests.

The institutional environment in which choosing to go to court is a viable option occurs when actors are faced with a relatively high number of oppositional Member States, i.e. in the event that an organisational actor (e.g. a Member State government or a part thereof) is very opposed to an EU rule or there is a lack of consensus among Member States to change a particular measure. Secondly, in times of a legislative deadlock, litigation may be an effective means of shaping public policy. ${ }^{692}$ The rise of far-right political

\footnotetext{
${ }^{687}$ Weiler, J., H., The Constitution of Europe: "Do the new clothes have an emperor?" and Other Essays on European Integration (Cambridge University Press, Cambridge, 1999) as cited by Bouwen and McCowm, 'Lobbying versus Litigation: Political and Legal Strategies of Interest Representation in the European Union, Empirical Studies of Interest Representation in the European Union', Special Issue of the Journal of European Public Policy, Working Paper 22, School of Public Policy, University College London, 20 January 2006, p. 8.

${ }^{688}$ Stone Sweet, A. and Brunell, T., 'Constructing a Supranational Constitution: Dispute Resolution and Governance in the European Community', 92 American Political Science Review (1999), p. 63-81, 1999 and

Stone Sweet, A. and McCown, M., 'Free Movement of Goods in the European Union', In Alec Stone Sweet, ed.: The Judicial Construction of Europe (Oxford University Press, Oxford, 2004) as cited by Bouwen and McCowm, 'Lobbying versus Litigation: Political and Legal Strategies of Interest Representation in the European Union, Empirical Studies of Interest Representation in the European Union', Special Issue of the Journal of European Public Policy, Working Paper 22, School of Public Policy, University College London, 20 January 2006, p.8.

${ }^{689}$ McCown, M., 'The European Parliament Before the Bench: ECJ Precedent and EP Litigation Strategies' 10 Journal of European Public Policy (2003) p. 974-995 as cited by Bouwen and McCowm, 'Lobbying versus Litigation: Political and Legal Strategies of Interest Representation in the European Union, Empirical Studies of Interest Representation in the European Union', Special Issue of the Journal of European Public Policy, Working Paper 22, School of Public Policy, University College London, 20 January 2006, p. 8.

${ }^{690}$ Bouwen, P. and McCown, M., 'Lobbying versus Litigation: Political and Legal Strategies of Interest Representation in the European Union, Empirical Studies of Interest Representation in the European Union', Special Issue of the Journal of European Public Policy, Working Paper 22, School of Public Policy, University College London, 20 January 2006, p. 8.

${ }^{691}$ Ibid., p. 9 .

${ }^{692}$ Ibid., p. 10.
} 
movements and parties throughout Europe and, thus in the European Parliament, may increase the legislative deadlock which could entail consequences for advocacy groups' influence and the choice of interest representational strategies.

Besides the environment in which interest groups operate, characteristics intrinsic to interest groups shape their recourse to litigation strategies, similar to their choice of access strategies. ${ }^{693}$

As for the organisational structure, Alter and Vargas found that the broader or more encompassing the interest group's mandate or constituency is, the less likely it will choose a litigation strategy. ${ }^{694}$ The bigger the interest group's constituency, the harder it is for them to achieve members' consensus, and the more likely that one of the members' interests will be violated by a general ruling. It follows from this line of reasoning that individual corporations and national associations are expected to litigate more than European trade associations, for instance.

\subsection{Empirical Data of Direct Selling Advocacy Methods in the EU}

\subsubsection{Trade Associations}

\subsubsection{European Direct Selling Trade Associations ${ }^{695}$}

Direct selling is an industry that has split into two advocacy groups in Europe, each represented by a trade association, Direct Selling Europe (DSE) and Seldia, the European Direct Selling Association - both of which will be described in detail in the present sub-chapter.

The original trade association, Seldia, the European Direct Selling Association (which used to be called the Federation of Direct Selling Associations, FEDSA, before 2011) represents 28 Member Direct Selling Associations (DSAs) of which 23 are in EU Member States and the other 5 in Norway, Kazakhstan, Russia, Ukraine and Turkey, as well as 16 corporate members (companies). Seldia is a member of the World Federation of Direct Selling Associations.

\footnotetext{
${ }^{693}$ Ibid., p. 10.

${ }^{694}$ Alter, K. and Vargas, J., 'Explaining Variation in the Use of European Litigation Strategies', 33 Comparative Political Studies, Number 4 (2000), p. 452-482., p. 473.

${ }^{695}$ The section is partly based on the interviews conducted with DSE Managing Director Mr. Oscar Cano Arias on 29 May 2013 in Brussels, Seldia Executive Director Mr. Maurits Bruggink on 2 December 2013 in Brussels and Seldia Internal Affairs Director Mrs. Marie Lacroix on 20 May 2013 in Brussels. Quotes in the section will not be referenced further.
} 
Direct Selling Europe, the other European trade association, consists of 'member companies and national direct selling associations [that] together represent about half of the direct selling industry in the European Union in terms of turnover. Besides the significant operations that DSE members have established in Europe, they support European integration and economic growth by operating the majority of their production facilities in the European Union area.' ${ }^{696}$ Direct Selling Europe represents 5 member DSAs (4 of which are in EU Member States, the fifth is the Swiss DSA) and 11 corporate members (companies). DSE is not a member of the World Federation of Direct Selling Associations.

Due to the fact that there is no representative statistical research on the direct selling industry, the trade associations' exact share of the European market cannot be sized. What is available, however, is the global ranking of direct selling companies indicating the 100 largest firms' annual net sales which is perhaps worth a glimpse.

According to the 2015 global ranking of direct selling companies based on their annual net sales, ${ }^{697}$ the first ranking was Amway/Alticor (USD10.8BN), the $3^{\text {rd }}$ Herbalife (USD5BN), the $4^{\text {th }}$ Mary Kay (USD4BN), the $9^{\text {th }}$ NU SKIN (USD2.57BN), the $11^{\text {th }}$ Oriflame (USD1.68BN), the $22^{\text {nd }}$ ACN (USD827M), the $48^{\text {th }}$ Party Lite (USD347M), the $57^{\text {th }}$ LR Health and Beauty Systems (USD303M), the $53^{\text {th }}$ PM International (USD313M), belong to the Seldia group - the other corporate members (Captain Tortue, Energetix, Nikken, NL International, Morinda and Kyani) did not make it to the top 100 direct selling firms based on their annual net sales in 2014. Globally, Seldia's 9 largest corporations (that have made it to the global top 100) have generated USD25.8BN net sales in 2014 globally.

Assessment of the global top 100 direct selling firms show that the $3^{\text {rd }}$ largest firm, AVON (USD8.9BN), the $5^{\text {th }}$ Vorwerk (USD3.9BN), and the $8^{\text {th }}$ Tupperware (USD2.6BN) belong to Direct Selling Europe, whereas Just, Nutrimetics, Deesee, Jafra, AMC and Victoria Benelux did not make it to the global top 100. Globally, DSE's largest corporations (that have made it to the global top 100) have generated USD15.4BN net sales in 2012 globally.

Subsequent to this brief distraction, we now return to the original topic and, in the sections to follow, will attempt to explore the reasons why the industry has split, how the original European federation has evolved, what events led up to the industry split, what the causes of the chasm may or may not have been and what the aftermath of the split

\footnotetext{
${ }^{696}$ DSE website, “About Direct Selling Europe”, http://www.directsellingeurope.eu/basic-page/about-directselling-europe-dse (last visited 17 September 2014)

697 The ranking was published by Direct Selling News on 8 April 2015; http://directsellingnews.com/index. php/view/2015_dsn_global_100_list\#.VWwpTM9Viko (last visited 1 June 2015)
} 
was in terms of the division of the original association's membership. Then, the operation and institutional characteristics of the two trade associations will be assessed. Thereafter, the internal organisational structure and the distribution of powers between the two federations' members will be compared and analysed. Lastly, DSE's and Seldia's advocacy techniques both in the stricter as well as in the wider sense will be scrutinised - to the extent that confidentiality obligations of the parties involved allow.

\subsubsection{The Industry Split}

Direct Selling in Europe is a small industry represented by two trade associations. In search for the answer as to why the industry advocacy has split, the current section describes the history of the industry's interest representation in Europe and the events leading up to the chasm. Subsequently, the daunting challenge to analyse the reasons behind the industry split will be faced and three possible explanations for the current controversy will be offered.

The first national direct selling associations (DSAs) were created in the UK, Germany, France, Belgium and Italy. It was in 1968 that these national trade associations founded a Federation called "Fédéeration de la Vente et du Service à Domicile" (FEVSD), an umbrella organisation that represented the interests of the direct selling industry. In 1992, the name of the federation -which already had 15 member DSAs at the time- was changed to "Federation of Direct Selling Associations" (FEDSA). ${ }^{698}$

Following over a decade of functioning as a European interest group, FEDSA underwent major changes and eventually split in the years 2006 and 2007 due to disagreements between its members concerning the voting system, as the "official explanation" suggests. The Federation of Direct Selling Associations at the time used to have a weighted voting system which was somewhat imbalanced in that it favoured associations of countries with smaller population sizes (e.g. Luxembourg), whereas associations of countries with larger population sizes were slightly underrepresented (e.g. Germany). As the result of the unresolved conflicts over the voting system, the Austrian, Belgian, French, German, Italian, Luxembourger and Swiss associations left FEDSA.

Direct Selling Europe (DSE) -the competing European direct selling trade association- was founded in 2007 by the Austrian, Belgian, German and Swiss associations. In the meantime, the direct member companies that had left FEDSA by 2006 -

698 Seldia website, "History of Seldia" http://www.seldia.eu/index.php?option=com_content\&view=article \&id=11\&Itemid=143 (last visited 17 September 2014) 
Tupperware, Vorwerk, AMC, Lux and Pierre Lang- joined DSE (the latter is no longer a member). ${ }^{699}$

Other associations that had left FEDSA -the French, Italian and Luxembourger associations- did not join DSE. The French DSA returned to FEDSA in 2009, which was followed by the reorganisation of the entire European trade association.

As a result of the restructuring of FEDSA, the voting system has become more balanced within the general assembly. Secondly, organisational changes have been put in place allowing a fair and proportionate division of power between the national associations and corporate members within the trade association. Thirdly, a new managing director (a professional lobbyist with an established political network) was recruited to spearhead Seldia's lobbying actions. To mark the complete change in the trade association, the association's name was changed from FEDSA (Federation of Direct Selling Associations) to Seldia, the European Direct Selling Association in 2011.

Since the realisation of the reforms, one of the Italian associations, Avedisco, and the Luxembourger DSAs have also returned to Seldia, and new companies -Kyani, Morinda (former Tahitian Noni), LR Health and Beauty, Captain Tortue, Energetic and ACNbecame corporate members of Seldia. In addition, the DSA of Kazakhstan and PMInternational joined Seldia in early 2014. However, due to disagreements concerning the industry's Codes, AVON left Seldia and joined DSE in 2015.

Corporate members of Seldia are predominantly American MLM firms, but there are also European companies like Oriflame (Swedish) or LR World (German). Two of the three largest direct selling corporations - Amway and Herbalife - as well as the fourth biggest company, Mary Kay are members of Seldia, whereas the second, the fifth and eighth largest, AVON, Vorwerk and Tupperware are DSE's members.

Seldia has 28 national trade associations, covering practically the entire European Union with the exception of the Germanic countries: Austria, Germany, Switzerland, and an Italian trade association, Univendita (the industry in Italy is split as well: DSE's Italian member is "Univendita", while Seldia's is called "Avedisco").

Like Seldia, Direct Selling Europe maintains its permanent headquarters in Brussels which is led by the Managing Director and operates under the supervision of a Board of Directors. Founded in January 2007 by four national member associations (Austrian, Belgian, German and Swiss) and 11 corporate members, the membership of DSE also has undergone some changes since its foundation. Eismann Tiefkuhl Heimservice GmBH, InMediaONE and Pierre Lang stepped out, but Nutrimetics, Victoria Benelux, Jafra Cos-

${ }^{699}$ DSE's website , "History of DSE”, http://www.directsellingeurope.eu/basic-page/about-us/history (last visited 17 September 2014) 
metics have joined, alongside with another Italian direct selling association, Univendita. AVON joined in 2015 after it had left Seldia. DSE's corporate members are predominantly European (Vorwerk and VIW International are German; Deesse, Just and Lux are Swiss; and "Benelux Victoria" is obviously European as well) and have a mixture of MLM (e.g. AVON, AMC or Jafra) and single-level marketing (e.g. Vorwerk) companies.

In an interview conducted with DSE Managing Director Oscar Cano Arias, it was asserted that the way to differentiate DSE from Seldia was that 'DSE represents only companies and associations that can prove a strong record of ethical behaviour and customer-oriented philosophy. None of our [DSE's] members have been condemned or have been brought to justice against their business model. This is particularly welcomed by the consumers' representatives, either at EU or national level, with whom DSE has good working relationship.' The implications here are that DSE distances itself from companies that have been tried for operating pyramid schemes, like Amway or Herbalife. It is true that both companies have had to stand trials because of their business models in the past: Amway was under an FTC investigation in the US in 1979 but was cleared of pyramid scheme allegations and was subsequently cleared of the same allegations by a Belgian court in 1997, and a United Kingdom court in 2008. ${ }^{700}$ Similarly, in December 2013, Herbalife won a Belgian appeals court ruling rejecting claims that the company is a pyramid scheme. The FTC then opened an official enquiry into Herbalife based on pyramid scheme allegations in March $2014^{701}$ but a year later the company was ruled to be a legitimate business.

In response to DSE's claim to be representing only companies that have a 'strong record of ethical behaviour', Seldia Executive Director Maurits Bruggink said that, 'the division is a result of one side of the industry wanting to position the split sector alongside the dichotomy of "good" and "bad" groupings of companies. However, this distinction cannot be justified by pointing to court cases in which companies have been involved. Firms that have had court cases have been operating for years, have produced sustainable economic growth and are today the most successful companies. Hence, the distinction between "legal" and "illegal" company groupings is purely hypothetical, an agenda imposed upon Seldia. Seldia intends to pursue its own, positive agenda and not define itself through distinguishing itself from DSE in any way.' Mr. Bruggink continued by asserting that 'splits have occurred in other industries or advocacy groups too - di-

\footnotetext{
700 Davidson, N., ExplosiveMLM.com, 'The Amway Law Suits Explained', 4 November 2010, http://explosivemlm.com/amway/amway-lawsuits-explained/ (last visited 17 September 2014)

${ }^{701}$ Stevenson, A. and Eavis, P., The New York Times, 'FTC inquiry into Herbalife Prompts Big Share Selloff, 12 March 2014, http://dealbook.nytimes.com/2014/03/12/herbalife-discloses-f-t-c-inquiry/?_php=true\&_type $=$ blogs \&_php=true\&_type=blogs\&_php=true\&_type=blogs\&_r=2\& (last visited 17 September 2014)
} 
rect selling is thus not alone with this issue. What is important, however -just like in European politics- is to find commonalities and move along these lines instead of looking for differences.'

A third explanation for the industry split was given in the course of an interview conducted with a leading direct selling executive who has requested to remain anonymous: the interviewee said that while the split is a huge loss for the entire industry and it is an unforgivable mistake for the two sides to speak negatively about one another in public, conflict as such is an inherent characteristic of the majority of people working in the direct selling sector. Direct selling companies are highly competitive and tend to hire achievement-oriented but also very competitive people who simply will not cooperate. It is very likely, contended the interviewee, that the confrontational nature of direct selling professionals played a decisive role in the split.

In summary, the representatives of the two competing trade associations have claimed that the split occurred either along the lines of the legality of member corporations' business models (as claimed by Mr. Arias) or, in essence, the confrontational behaviour of an industry grouping, DSE (as explained by Mr. Bruggink). For purposes of academic objectivity, it must be noted that these opinions may, at least to some degree, be biased on behalf of the beneficiaries of the two lobbying groups.

\subsubsection{Mission and Objectives of the European Associations}

Following the assessment of possible reasons why the industry has split, resulting in the establishment of a second direct selling trade association, the current section will look at what the main objectives and mission of DSE and Seldia are.

First and foremost, both DSE and Seldia are trade associations aggregating and representing the interests of their members towards European policymakers with regards to legislative developments that concern the direct selling business model.

Secondly, both organisations serve as self-regulatory bodies - as was described in chapter V, both associations use Codes of Conduct, regulating fair trading standards within the direct selling industry segments they represent. While the actual Codes were found to contain similar rules, private execution measures appeared to differ significantly. While Seldia has an institutionalised system of national Code Administrators and a pan-European, sector-specific ADR body for cross-border consumer disputes, DSE prefers to refer unresolved consumer complaints to the responsible ADR bodies. In B2B complaints, DSE's Board of Directors is the competent instance, whereas under Seldia's auspices, complaints of this nature are handled by an independent person or body as Code Administrator appointed by the DSA or an independent arbitrator. 
Seldia has a third objective, the collection of statistics for the direct selling industry. Data collection is of paramount importance for the whole of the sector as in a number of countries direct selling as a commercial activity does not have its own statistical number, ${ }^{702}$ hence government authorities in the respective countries cannot estimate the size of the industry. ${ }^{703}$ Given that Seldia and WFDSA can only ensure that DSAs provide information of their members, but not of the companies outside the DSAs, despite considerable efforts to search and aggregate data globally the resulting statistics are not representative. The other European trade association, DSE, 'disagrees substantially with Seldia/WFDSA on the methodology of their statistics, which we [DSE] consider as completely exaggerated' said DSE Managing Director Oscar Cano Arias.

Nevertheless, the statistics produced may be seen as indicators of major trends and a basis of estimations which -given the lack of other aggregated data and research- is invaluable, despite the fact that it is not representative.

\subsubsection{Advocacy}

The main mission of the two trade associations, DSE and Seldia, is to represent and advocate for the interests of the direct selling industry at the European level. The present section will look at advocacy both in a stricter sense, the "political strategies" covering legislative lobbying and direct access to European institutions, as well as advocacy in a broader sense, including "voice strategies", namely public relations and the organisation of lobbying events.

When asked whether it was more difficult to lobby for the direct selling industry due to its negative reputation, Maurits Bruggink explained he has lobbied for the interests of a number of other industries that may be deemed controversial or perhaps less popular, such as for spirits producers or the gambling industry. Mr. Bruggink however claims to have experienced

'a surprising degree of hostility against the direct selling industry in comparison to other sectors - direct selling is perceived much more negatively than the alcohol industry for instance. Alcohol, although potentially detrimental for human health, is a popular product people like to consume and therefore this industry is generally not perceived so adversely. Similarly, in gambling, the gaming aspect is always positive which gains supporters for the industry.

\footnotetext{
${ }^{702}$ There are only a very few exceptions, like Poland, where direct selling as a commercial activity does have a statistical number.

${ }^{703}$ Interview conducted with Seldia Internal Affairs Director Mrs. Marie Lacroix.
} 
Direct selling, on the other, hand has significantly less supporters. People are either not familiar with the sales channel itself or are vehemently against it, but very few would actually support it. Those who are pro-direct selling are usually involved in the industry themselves.'

As a basis for the formulation of European collective actors' positions, both DSE and Seldia monitor legislation, gather intelligence and disseminate information to their members. Obtaining and distributing information on the European legislative developments to members (particularly to those that do not lobby in Brussels directly) in a timely manner is a key function of European associations and both organisations have claimed to have an established network through which information and intelligence is collected. Besides gathering information on European institutions' positions regarding relevant legislative proposals, both associations need to try to obtain information on the other actor's intents, position and lobbying tactic in order to fend off any detrimental move their competitors may make to gain advantage.

The European associations' positions are taken based on the acquired information and the aggregation of members' interests.

With respect to interest representation towards European institutions, Seldia Executive Director Maurits Bruggink explained that in theory, Seldia -as a representative of aggregated European interests- should lobby solely the European Commission as the one institution that represents non-national interests, whereas the Council and the European Parliament should be lobbied by the DSAs. Seldia's role is to orchestrate, to collect and distribute information, and to provide DSAs with position papers and guidance on lobbying their national governments and their national MEPs. In practice, Seldia lobbies all three European institutions, given that DSAs are often either understaffed or do not have the professional expertise to advocate interests at high political levels.' Having said that, Mr. Bruggink believes Seldia's lobbying activities to be the most successful at the Commission's level.

Similarly, Direct Selling Europe lobbies all three European institutions: the Commission, the European Parliament and the Council. In the process of liaising with EU institutions, when asked whether national affiliation plays a role for the predominantly Germanic DSE, the Managing Director's response was that 'it might seem logical but it is not always the case. Furthermore, national affiliation varies depending on the target institution, e.g. it is more relevant in the EU Parliament and at Commissioner or Director General in the Commission.' [sic] Furthermore, political affiliation for DSE is 'definitely a playing factor when dealing with the EU Parliament, Council and the senior members of the Commission.' 
The trade association representatives have claimed to adjust their messages to the nature of the institution they are approaching: the Commission is addressed with a higher level of technicality, whereas communication with the European Parliament or the Council is more focused on the interests of the respective constituencies or Member States. A good example of targeted messaging was provided by Seldia in the course of the lobbying activities concerning the Consumer Rights Directive. Position papers of very high technicality were submitted to the Commission, while the position papers used in the Parliamentary phase used considerably less technical terms and legal phrases and were much easier to understand for the general public.

As indicated in the chapter on direct selling advocacy concerning the pyramid scheme definition under European law (chapter IV), Seldia (at the time FEDSA) also used commissioned studies as a frame of reference for lobbying purposes. With the support of Amway Corporation, Seldia commissioned a law firm, Oppenheimer Wolff and Donnelly LLP to carry out a comparative analysis of Member State laws concerning new marketing practices in the field of direct selling in 1999. The credibility of the study was enhanced by the fact that it was conducted by a renowned law firm and provided a strong basis of the industry position.

There were no public records of the two European trade associations being engaged in strategic litigation for the purposes of interest representation.

Application of "voice strategies" - public relations and the organisation of lobbying events- appears to be a very strong point of Seldia. The association's director Mr. Bruggink said:

'It was actually the negative industry image and its detrimental impact on the industry advocacy that triggered changes in the lobbying strategy of Seldia: in March 2012, with the approval of Seldia's CEO Council, it was decided that more focus will be laid on highlighting positive aspects of direct selling and thereby gaining more supporters for the industry.'

Promotion of the direct selling industry through entrepreneurship events -and especially women entrepreneurship- in the European Parliament has been among Seldia's most successful PR endeavours yet. As established in the chapter on the promotion of entrepreneurship, positioning direct selling as an industry rooted in entrepreneurial values has contributed to a more positive redefinition of the industry and helped establish contacts with both senior policy makers as well as civil society. With the broad support and participation of the latter, mainly women entrepreneurs' NGOs and advocacy groups, Seldia has also established its first front group, the Women Entrepreneurship Platform. 
Both event management as well as the establishment of the front group are novel and positive elements in the European direct selling industry's lobbying activities.

DSE on the other hand is more focused on legislative lobbying or advocacy in the strict sense, although DSE's Managing Director said their trade association does organise lobbying events 'when needed and if there is a real added value' (the last event was the 'Conference on Direct Selling \& Consumer Protection in the EU' held in the Solvay Library on 22 September 2011).

Lastly, the question whether national governments and national issues are to be lobbied by the European trade associations arose recently, posing a challenge to the conventional structure and division of labour between European associations and their national member associations. DSE's Managing Director said that 'The remit of action is clear between DSE and its members: DSE focuses its campaigns at EU level in Brussels; members are active at national level. DSE of course provides its expertise and support when relevant and needed.'

Similarly, Seldia's Mr. Bruggink asserted that 'Seldia has begun to lobby at national levels only very recently; national lobbying was originally not meant to be Seldia's task, yet legislative proposals in certain Member States, often combined with the lack of staff or professional lobbyists at the national direct selling associations, has prompted the need for Seldia to intervene.'

\subsubsection{National Direct Selling Trade Associations}

Direct Selling Association (DSA) is the name of trade associations that represent the interests of direct selling companies, primarily those that operate on the basis of multilevel marketing compensation plans. Direct Selling Associations engage in lobbying efforts and interest representation actions of the multi-level marketing industry vis a vis national and European policy makers, and engage in public relations on behalf of the corporate membership.

National direct selling associations, as local lobbying groups, aggregate domestic interests of their membership and articulate the aggregated national interests towards the national governments. Moreover, national associations have an important role to play at European level through representing the interests of their respective national- and European industry segment towards policymakers.

Given that the focus of the current enquiry is the direct selling industry's lobbying at European level, the empirical research of DSAs has focused on their political activities in the Brussels political arena. In order to map interest representation activities of national direct selling associations at European level, a standardised questionnaire was composed 
and sent to all national direct selling associations in EU Member States. The questionnaire sent to national direct selling associations can be found in Annex II.

The aim of this part of the empirical research was two-fold.: The first goal was to explore the extent to which national associations complement the European trade associations' lobbying activities in Brussels by communicating national and European interests to the European institutions. To that end, DSAs have been asked whether they articulate aggregated national interests and/or aggregated European interests towards the European Commission, the European Parliament and the Council of Ministers. Furthermore, the question whether the DSAs attempt to instigate national governments to intervene in court cases of the Court of European Justice was also posed to the national associations.

The questions asked in relation to DSAs' European lobbying activities were as follows:

- Does your Association articulate national industry interests towards the European Commission? (Q5)

- Does your Association articulate European industry interests towards the European Commission? If yes, please provide an example! (Q6)

- Does your Association articulate national industry interests towards the European Parliament (your national Members of the European Parliament)? If yes, please provide an example! (Q7)

- Does your Association articulate European industry interests towards the European Parliament (your national Members of the European Parliament)? If yes, please provide an example! (Q8)

- Does your Association articulate national industry interests towards the Council of Ministers (your national representatives of the Council)? If yes, please provide an example! (Q9)

- Does your Association articulate European industry interests towards the Council of Ministers (your national Members of the Council)? If yes, please provide an example! (Q10)

- Has your Association ever tried to persuade its national government to intervene in a case of the Court of Justice of the European Union? If yes, please provide an example! (Q11) 
The second main purpose of the questionnaire was to enquire into the need for European associations to lobby at national level, as the traditional division of labour between national associations and European associations has been challenged recently and European trade associations were required to lobby at national level. The fourth question of the questionnaire attempted to look into this issue:

- In your opinion, would it be useful if DSE/Seldia provided more assistance in national lobbying activities or is lobbying national governments the sole responsibility of DSAs? (Q4)

Lastly, all national direct selling associations have been asked about the number of staff they employ and whether the DSAs have trained lobbyists in order to examine whether the size and/or employment of professional lobbyists is in correlation with the national associations' advocacy.

- What size is your Association? (number of full time staff) (Q2)

- Does your Association employ public affairs experts/trained lobbyists? (Q3)

National direct selling associations of all EU Member States have been contacted with a request to participate in the research.

Eleven direct selling associations (all of which are EU Member State representatives) responded to the questionnaire voluntarily, but, given the strictly confidential nature of the information, it will not be revealed which national associations participated in the research and, for this reason, a country-related analysis of DSAs cannot be provided either.

Seldia has 28 member associations: 23 DSAs that represent EU Member States (Bulgaria, Croatia, Czech Republic, Denmark, Estonia, Finland, France, Greece, Hungary, Ireland, Italy, Latvia, Lithuania, Luxembourg, Netherlands, Poland, Portugal, Romania, Slovenia, Slovakia, Spain, Sweden and the United Kingdom) and 5 DSAs that represent non-EU members (Norway, Kazakhstan, Russia, Turkey and Ukraine). Direct Selling Europe has 5 member associations, four of which represent EU Member States (Austria, Belgium, Germany and Italy) whereas their fifth DSA member represents Switzerland. Altogether, 26 Member States have DSA representatives (there are two Italian DSAs) Cyprus and Malta do not have DSAs.

The fact that 11 out of 27 DSAs (26 Member States, there is a case of duplication in Italy) representatives responded to the questionnaire means that a little over $40 \%$ of EU member DSAs participated in the empirical research.

Participation in the research, as indicated, was voluntary and therefore the sample is a convenience sample. For purposes of the research concerning direct selling associa- 
tions' individual institutional access, it will be assumed that the population consists of homogenous members. While the lobbying power of DSAs is clearly unequal (DSAs of bigger Member States are more resourceful and thus have a greater degree of influence potential) and from this perspective, DSAs could not be deemed homogenous, the emphasis here is not on the weight of opinion or the potential to determine the legislative output but on the national direct selling association's advocacy activity and patterns, i.e. whether the DSAs as single units of advocacy only lobby their governments or if they also attempt to access individual European institutions to articulate national- and/or European interests.

The diagram below indicates the pattern of accuracy growth when sample size increases - the accuracy is $100 \%$ when the entire population is examined, but the pattern of growth of accuracy is not linear.

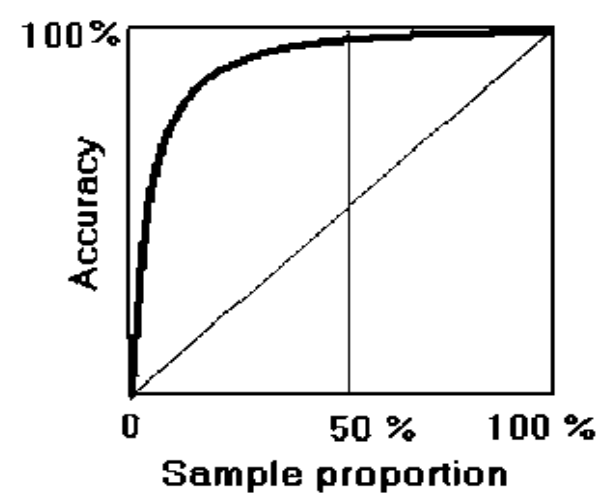

Accuracy as a Function of Sample Size

Source: FAO Corporate Document Repository, http://www.fao.org ${ }^{704}$

Thus, pre-supposing that the population is homogenous (consisting of lobby groups representing the sectorial interests of the direct selling industry), it may be argued that the $40 \%$ respondent rate is sufficient to at least assume the existence of certain patterns of interest representation towards European institutions, bearing in mind that the generalisations may not be fully accurate and as such could be subject to debate.

Responses of the direct selling associations have been summarised in the chart below.

704 FAO Corporate Document Repository, General Sampling Considerations http://www.fao.org/ docrep/004/y2790e/y2790e05.htm 


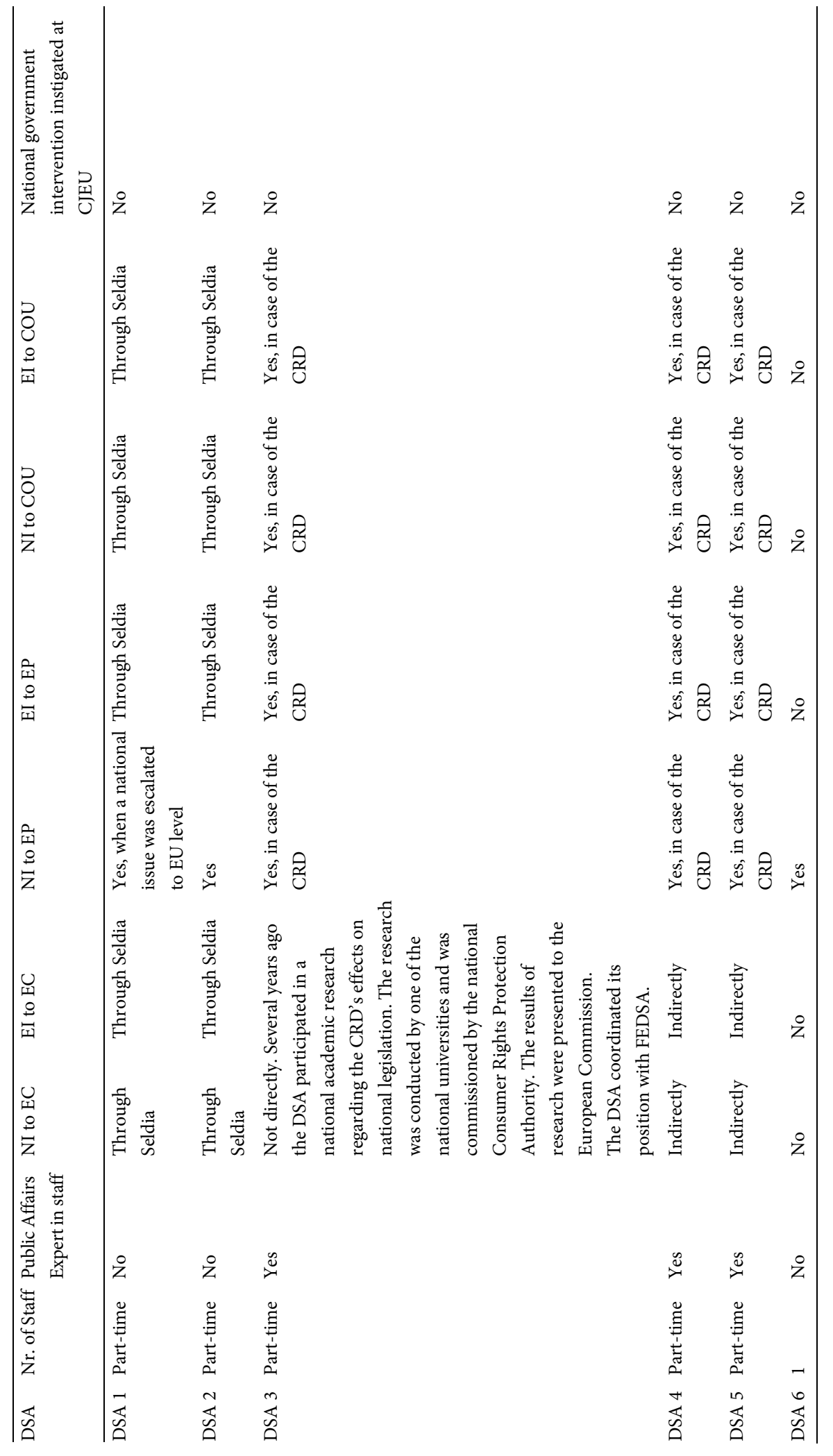




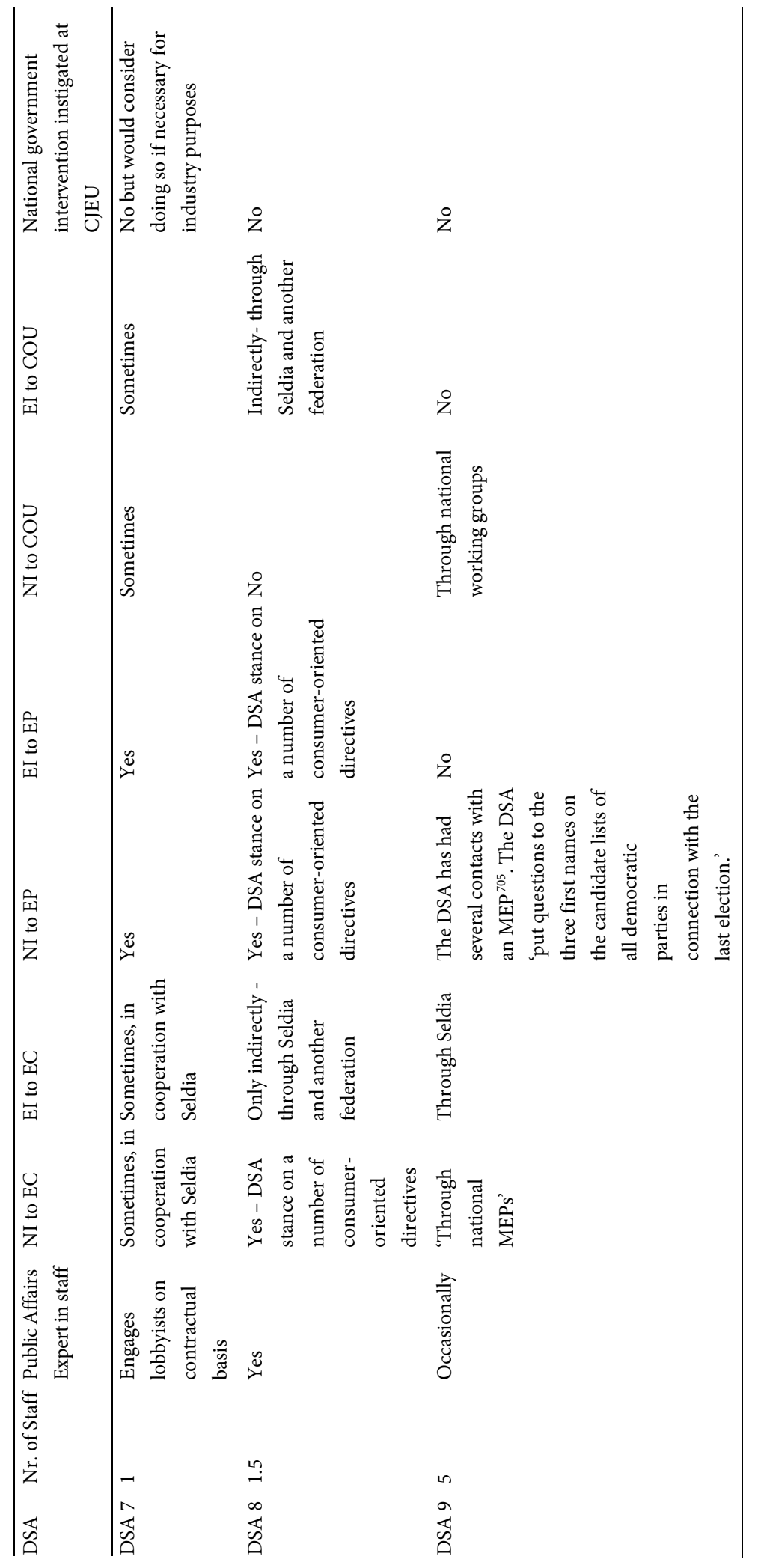




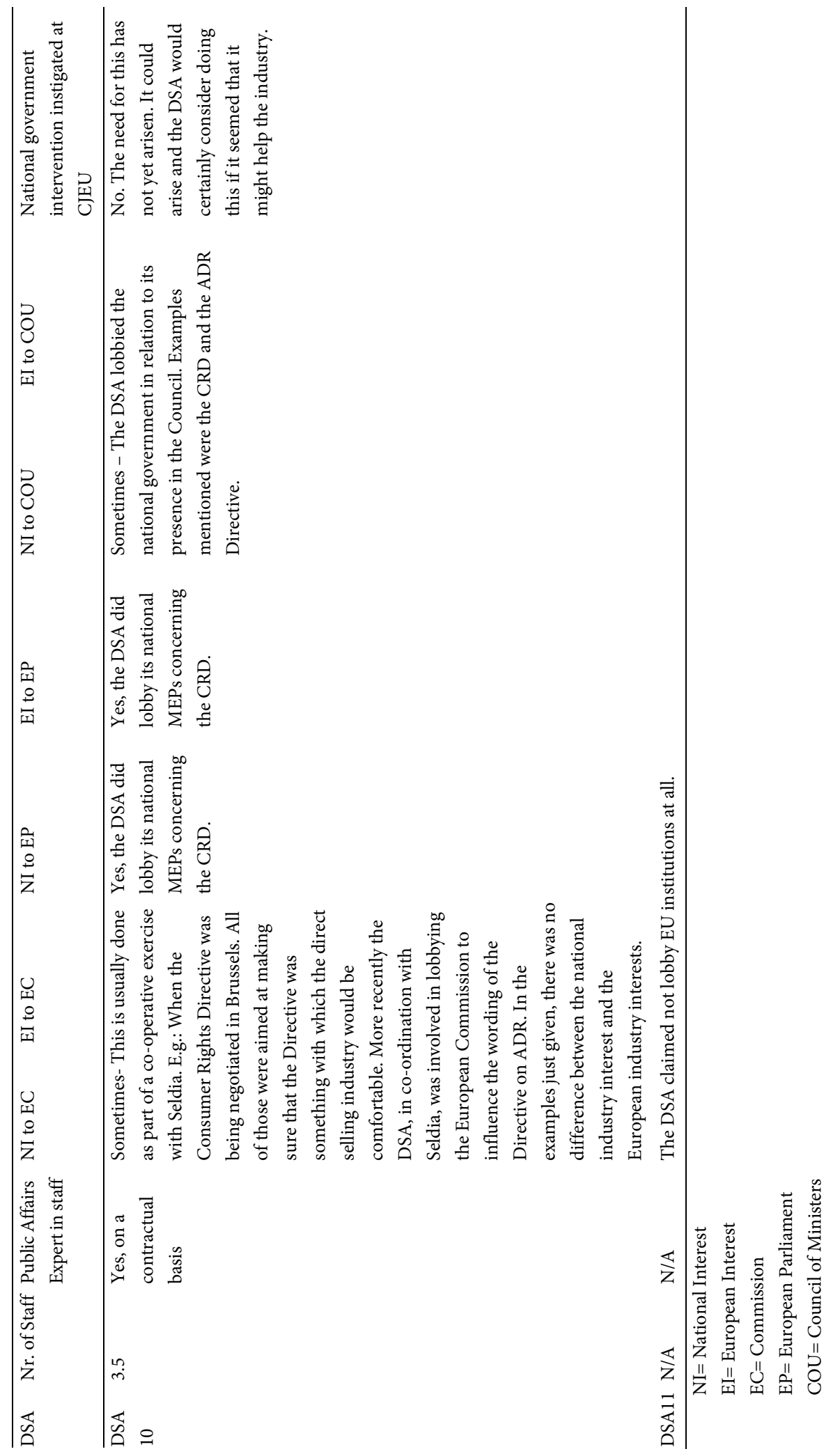


Empirical research has revealed a number of different findings concerning institutional access and DSAs' (lack of) involvement in strategic litigation.

As expected, European institutions are not lobbied equally by the national associations. The European institution that is lobbied directly least by national associations is the Commission ( 3 out of 11 respondents claimed to articulate national interests, while only 2 respondents reported to have articulated European interests towards the Commission). All other national associations reported to articulate both national- as well as European interests towards the Commission indirectly, mainly through European advocacy groups (e.g. Seldia, but other federations were also mentioned), one DSA also claimed to have taken part in academic research. The main example brought forward by DSAs was the relatively recent dossier of the Consumer Rights Directive, but advocacy concerning the ADR Directive's wording was also mentioned.

Curiously, none of the DSAs used the example of filing complaints with the European Commission concerning national trading bans when asked whether they articulate national interests towards the Commission directly.

Overall, responses indicate that the European trade associations aggregate national interests and play a leading role in lobbying the European Commission.

It has been found that the European Parliament is the European institution lobbied directly by DSAs most frequently (10 out of 11 DSAs said to have lobbied their national MEPs directly concerning national matters, while 6 out of 11 DSAs have advocated European interests towards MEPs directly). The overwhelming majority of DSAs that did lobby the EP directly did so in the course of the negotiations connected to the Consumer Rights Directive whereby no real distinction was made between national and European interests of the industry. MEPs have reportedly been contacted in a national matter that escalated to European level.

Only one DSA reported to have posed parliamentary questions to their national MEPs in the European Parliament.

It was established that the Council is the institution that is lobbied by the national direct selling associations the second most frequently: 6 out of 11 DSAs reported to articulate national interests to their respective representatives in the Council of Ministers; while European interests have been signalled to the Council by 5 DSAs again, mainly in the course of the deliberations about the proposed Consumer Rights Directive, when the European industry position was communicated to the DSAs' respective national representations in the Council. One DSA has claimed to have lobbied the Council through its national government regarding the wording of the ADR Directive.

None of the national direct selling associations have lobbied their national governments in order to instigate an intervention in any of the cases of the Court of Justice of 
the European Union. A number of DSAs claimed that the need to get national governments to intervene at the Court proceedings has never arisen but that the DSAs would certainly consider lobbying national governments, if it seemed that intervention might help the industry.

The intensity of direct selling associations' advocacy in Brussels has thus proven to be very divergent - the general tendency appeared to be that those DSAs tend to lobby European institutions directly that employ or contract trained lobbyists and a higher number of full-time staff. One DSA claimed not to lobby in Brussels at all, while there were three other DSAs that reported to have indicated national interests directly to MEPs only. No other direct lobbying was performed in Brussels.

As regards the second pillar of research concerning national direct selling associations' national advocacy and the question whether Seldia should lobby (more) at national level, the unanimous response was that national governments are to be lobbied in principle by the national associations, as that it is the responsibility of national associations to articulate the industry's interests towards national policymakers. Moreover, by having a single agent of communication (the DSA) messages get across much more effectively than duplicating the voice of the industry by involving Seldia. Five DSAs have indicated that Seldia assistance would at times be welcome on an as-needed basis, given that Seldia's support can increase the credibility of the industry position by providing a European perspective and best practices from other Member States. 


\subsubsection{Corporate Lobbying}

Individually and collectively lobbying direct selling companies are the third group of actors to be assessed in the course of the current enquiry.

In general, according to Seldia's website, direct selling companies range from those with less than 1 million euros in annual turnover to medium-size and large firms with turnover above 1 billion euros. Some companies operate in just a few countries, some others on a worldwide basis, but many more are national or often locally based. The majority of direct selling companies manufacture and control the production of their goods. Direct selling is suited to the sale and distribution of almost any category of consumer goods, but the strongest sectors are cosmetic and personal care products, household items and wellness goods. Other product categories include food and beverages, nutritional products, jewellery and clothes, books, toys and games, home improvement products, etc. Direct selling is also a cost-effective means of retail for services such as telecoms, gas and electricity supplies.

Direct selling corporations invest heavily in research, training and marketing but are also socially responsible firms involved in community programs at both local and international levels. ${ }^{706}$

The aim of this section is to observe and establish patterns of corporate lobbying in the direct selling industry. To do so, five case-studies will be presented, which will form the basis of a comparative analysis of the findings in order to establish patterns of direct selling corporate lobbying behaviours in section 7.5.2.

\subsubsection{Research Method and Company Introductions}

In an effort to provide an overview of the industry advocacy's third main group of actors, individual companies, qualitative research was carried out involving five leading multinational direct selling firms in Brussels. Direct Selling Europe has 11 corporate members, one of which has a Brussels representation, whereas Seldia has 15 corporate members with 4 corporations lobbying in Brussels individually (one of which is represented by a consultancy). The interviews were conducted on a voluntary basis wherefore the findings may not necessarily reflect the entire population of direct selling corporations.

In-depth interviews based on a standardised questionnaire have been conducted with public affairs managers and top executives who are in charge of the examined cor-

\footnotetext{
${ }^{706}$ Source: Seldia's website, “Direct Selling Companies and Products" http://www.seldia.eu/index.php?option= com_content\&view=article\&id=6\&Itemid=138 (last visited 17 September 2014)
} 
porations' interest representation. The questionnaire prepared for said interviews was composed the way that allows for the detailed exploration of the main aspects and fields of corporate lobbying. The first group of questions concern the firms' public affairs management structure, whereas the subsequent seven groups of questions represent the seven interactive pillars of European lobbying, resembling ${ }^{707}$ Daniel Gueguen's concept $^{708}$ of European public affairs. ${ }^{709}$ Four groups of questions concern the tools for lobbying: networks, communications, ${ }^{710}$ legislative monitoring and business intelligence activities of the firms, whereas the three subsequent groups of questions regard lobbying strategies: intervention, strategy and coalitions. The standardised questionnaire can be found in Annex III.

The firms were chosen in a way that they would not only reflect the various sizes of direct selling firms and the products ${ }^{711}$ most often offered through the direct selling channel but also introduce various lobbying strategies applied by the individual corporations.

As will be seen in the descriptions to follow, three of the five firms' public affairs managers requested confidentiality and the non-disclosure of certain data such as their and the firms' names or revenues. Therefore, three corporations have been given madeup names and the identity of their public affairs managers will not be revealed. Interviewed were representatives of "SweetScent", "SuperFit", "Pinkify", ACN Europe and Kyani.

SweetScent Cosmetics ${ }^{712}$ is one of the world's five leading direct selling businesses. The corporation markets mainly cosmetics and has several million active distributors globally. SweetScent had been a long-time direct member of Seldia, the European Direct Selling Association at the time it was interviewed in 2012. ${ }^{713}$ SweetScent Cosmetics em-

\footnotetext{
707 The word "resemblance" is used deliberately: while Gueguen's model entails the pillars of Legislative monitoring, Business intelligence, Strategy, Networks, Coalitions, Lobbying and Institutional communication, this contribution looks at a slightly modified version of lobbying strategies.

${ }^{708}$ Gueguen D., European Lobbying, (2 ${ }^{\text {nd }}$ edition, published by Europolitics, Brussels, 2007), p. 98.

${ }^{709}$ Gueguen claims his model follows the Anglo-Saxon lobbying structure, which, in this case, is perhaps particularly convenient to apply as all of the analyzed corporations are American.

${ }^{710}$ Communication as part of lobbying - not PR and Communication of the firms in general.

711 According to the fact sheet issued by Seldia in 2011, the most popular product groups are cosmetics and personal care $(36 \%)$, household goods and home care $(22 \%)$, wellness products (14\%), home improvement (12\%), clothing and accessories (5\%), books, toys and stationery (4\%), foodstuff and beverages (4\%), utilities (3\%), others (1\%). The information can be found in Seldia's Annual Report of 2010-2011, p.22. http://www.seldia.eu/images/pdf/SELDIA\%20Annual\%20Report\%202011-2012.pdf (last visited 17 September 2014)

${ }^{712}$ Made-up name to protect the anonymity of the firm.

${ }^{713}$ Remark: Through its local branches, SweetScent is also a member of Seldia's member organizations, the Direct Selling Associations.
} 
ploys two public affairs managers ${ }^{714}$ in order to lobby the European Union's institutions directly, aiming to enhance its influence on policymakers.

SuperFit ${ }^{715}$ is mainly a nutrition company with annual net retail sales in excess of 3 billion USD and employs three public affairs staff. ${ }^{716}$

Pinkify Inc. ${ }^{717}$ is among the ten largest direct selling companies in the world and sells personal care products to consumers directly. The firm is present in over 30 markets worldwide as well as in several EU Member States. Pinkify's global independent sales force exceeds 3 million. Started as a small private business, Pinkify bases itself on traditional values and the importance of entrepreneurship to this day. Pinkify is represented through a consultancy.

The fourth corporation, ACN Europe, is the world's largest telecommunications service provider and is one of the leading direct sellers among all industries. Founded in 1993 by four entrepreneurs in the United States, the firm is rapidly growing to this day. Data related to the firm's revenue is confidential. It is a known fact however that ACN is present in 23 countries and four continents. Public affairs management of ACN Europe falls under the responsibilities of the general counsel, Paul Gagnier, who represents the corporation in trade associations like Seldia, of which ACN Europe is also a corporate member.

Kyani, the fifth company assessed, is a young direct selling company launched in 2007 in Idaho Falls, Idaho, USA. The company offers four nutritional products, one of them made out of an Alaskan blueberry, "ky-ani". The company is now present in 44 countries and has 13 offices around the world.

\subsubsection{Lobbying Strategies of Individual Firms}

The following chapter will explore the strategic political management of the five direct selling corporations: SweetScent, SuperFit, Pinkify, ACN Europe and Kyani. Subsequent to the introduction of each firm's organisational structure relating to public affairs management, the tools for lobbying (networks, communication, legislative monitoring and business intelligence) will be assessed, whereas the three following titles concern lobbying strategies (intervention, strategy and coalitions). Individual case studies will be followed by the comparative analysis of corporations' lobbying behaviour.

\footnotetext{
714 The government affairs manager requested anonymity.

${ }^{715}$ Made-up name to protect the identity of the firm.

716 The interviewee requested anonymity.

${ }^{717}$ Made-up name to protect the identity of the firm.
} 


\subsection{Case Study 1: Corporate Lobbying Activities of SweetScent ${ }^{718}$}

\subsection{The Firm's Public Affairs Management}

The public affairs staff of SweetScent Cosmetics has a wide range of responsibilities: monitoring European legislation and studying the risks for the company relating to the new proposals, as well as advocating the firm's interests towards the European political institutions. The public affairs staff also assists lawyers of the firm's local branches and articulates local issues towards European lawmakers, if deemed necessary. Furthermore, the public affairs staff coordinates the representation of the firm in trade associations such as the American Chamber of Commerce to the EU (hereafter AmCham EU) or Seldia.

While the public affairs manager is responsible for managing the dossiers, decisions regarding lobbying strategies are being made jointly by the public affairs manager and the director of public affairs.

The public affairs staff has a direct link to the legal department and are accountable to the head of legal affairs. The head of the legal department is the intermediary between the public affairs staff and the higher management of the firm.

\subsection{Network}

SweetScent has an established network with political institutions, which are contacted on an ad hoc basis, when a certain issue or dossier requires negotiations. The firm does not have specific informants within the institutions. Information regarding the EU institutions or developments in policymaking comes from 'here and there', by receiving newsletters and agendas or attending various meetings. Political affiliation does not play a role when networking with political institutions.

A member of Seldia, AmCham EU and Cosmetics Europe, ${ }^{719}$ the firm builds networks with other direct selling companies and American firms through trade associations. Seldia provides an opportunity to liaise with representatives of other direct selling firms and discuss policy issues and improvements in the sector without forming cartels. On the other hand, however, the corporations tend to cooperate only to a certain extent as, in the end, they are all competitors.

The firm does not contact or cooperate with NGOs or think tanks, and only networks with local law firms in order to settle legal issues. The government affairs manager does not have any contact with the press either.

\footnotetext{
718 The case study is based on the interview conducted with the public affairs manager of "SweetScent Cosmetics" on 27 June 2012.

719 The trade association representing the interests of the cosmetic, toiletry and perfumery industry.
} 


\subsection{Communications}

SweetScent regularly submits position papers to policymakers to articulate its position on dossiers. Maintaining media relations as such is left to the Communications and PR department. The public affairs staff does not issue press releases and neither do they conduct media- or lobbying campaigns. Rather, the corporation sponsors or supports Seldia's events, such as conferences or roundtable discussions, but does not organise lobbying-related public events itself.

\subsection{Monitoring Legislation and Business Intelligence}

Given the firm's profile, a rather wide range of regulatory issues are monitored on a daily basis. First and foremost, as SweetScent sells cosmetics, legislation relating to cosmetics, chemicals and raw materials is followed. Legislative action relating to direct selling, consumer law, consumer redress (alternative dispute resolution and collective redress), unfair commercial practices, and contract law are also under close scrutiny. Further areas of monitoring include labour law and the field of customs and taxes.

Monitoring legislation is achieved through multiple channels in which websites and newsletters of the European institutions - particularly those of the European Parliament and the Commission - play a very important role. Communications, papers, consumer agendas and timelines of the Commission are followed closely in order to obtain and analyse information on relevant dossiers.

It is the task of the public affairs managers to monitor legislation as well as to analyse information. Reports are circulated to the management, main pieces of news are communicated on a trimestral basis to the management, whereas specific information is forwarded to the technical experts working on a specific issue or dossier.

Following the communication and analysis of the information, the public affairs manager proposes a lobbying strategy and discusses it with his supervisor, who then gives his permission to apply the proposed strategy and to take action.

\subsection{Intervention}

When targeting European policymakers, the main focus is on the European Parliament and the Commission, where the public affairs manager knows certain officials. Although the Council of Ministers is approached by the firm occasionally, it is mostly Seldia's task to lobby this institution.

With regards to the European Parliament, rapporteurs and shadow rapporteurs are always targeted, as well as MEPs and the Legal Services that put amendments in place and carry out procedures. 
In the Commission, the main targets are the responsible desk officers and heads of unit. Similarly, when lobbying the Council of Ministers, there is no specific body or officer the firm approaches on a regular basis - it depends on the dossier whom the firm tries to contact in order to advocate its interests.

SweetScent attempts to intervene from the very early phases of the legislative process: the Commission is usually targeted before the general approach is published, but sometimes also after the publication thereof, depending on the content of the proposal. The firm contacts the rapporteurs and shadow-rapporteurs of dossiers in the European Parliament at the preparatory phase of a legislative act and it tries to intervene at the parliamentary phase of the decision making process, especially when amendments are being made to the legislative acts.

The firm usually approaches higher-level officers when lobbying, but it must be noted that much depends on the dossier involved in this respect. In principle, the firm prefers upstream lobbying techniques by contacting the highest-level officer available. Nevertheless, when dealing with technical issues, desk officers are approached as they have specific knowledge and expertise in their own fields.

\subsection{Lobbying Strategies}

The lobbying strategy of the firm is clearly proactive: the public affairs manager always tries to be as proactive as possible and strives to be the first to meet key officials, hoping that in this way SweetScent's pleas will be better heard and remembered. Meetings and networking tasks are usually divided between Seldia and the corporation. In an attempt to avoid dual meetings or overlaps, there is very close cooperation and coordination between the corporation and Seldia in scheduling talks and negotiations.

\subsection{Coalitions}

SweetScent is a member of three trade associations: AmCham EU, Seldia, and Cosmetics Europe. The firm is also a corporate (direct) member of Seldia and its local branches are members in the local direct selling associations (DSAs).

According to the public affairs manager, the membership of the corporation in the trade associations greatly enhances its lobbying powers. AmCham EU being one of the most powerful trade associations in Brussels, it can make its voice easily heard. However, it cannot focus on specific interests as Seldia can. In its size and influence, Seldia is considerably smaller and less visible than AmCham EU but it advocates the interests of the direct selling sector in particular. The corporation's lobbying activity is complemented by that of Seldia as the cooperation and coordination is very close between this firm and the direct selling trade association in that there is a clear division of tasks and 
negotiations. It is always ensured that there are no duplications of meetings or overlap of tasks. Meetings with key decision makers are only organised once; either a delegation of both the firm and Seldia attends or only either of the two. With AmCham EU, says the corporate representative, it is more difficult to coordinate regarding meetings. All trade associations provide the opportunity for networking and exchanging information.

\subsection{Case Study 2: Corporate lobbying strategies of SuperFit ${ }^{720}$}

\subsection{The Firm's Public Affairs Management}

In the EMEA region, the firm's public affairs work is led by a small group of public affairs professionals. This group cooperates closely and forms a report chain. The development of strategy on a particular issue is a collaborative effort with the final decision resting with the head of the department. The EU affairs managers have a certain degree of discretion when it comes to the day-to-day execution of strategy.

Public affairs professionals are responsible for monitoring legislation and reporting on (Commission) proposals that might affect the company. They contribute to the management of trade associations and directly lobby European institutions in particularly sensitive issues or regarding dossiers the trade associations do not deal with or have less influence on. Thus, direct lobbying of SuperFit with the EU institutions depends on the work done by the trade associations, the dossier concerned and the products of the company. For example, as the Consumer Rights Directive affected all direct selling businesses, it was mostly Seldia that lobbied, and SuperFit did not take as much direct action as it did in other areas.

\subsection{Network}

SuperFit has an established network with the political institutions, mostly with the European Commission. In the event that a law is being discussed, representatives of SuperFit hold bilateral meetings with specific Commission officials. According to the lobbyist's experience, it is easier to set up meetings with MEPs if the assistants are known by the public affairs managers personally. Due to the high volume of requests received by MEPs for meetings, this is the reality of engagement with the Parliament and maintaining a network of contacts is consequently of crucial importance.

SuperFit is a member of a number of trade associations which help the corporation to reach out to other companies as well as to NGOs such as BEUC, the European Con-

\footnotetext{
${ }^{720}$ The case study is based on the interview conducted with the public affairs manager of "SuperFit" on 6 July 2012 .
} 
sumer Organisation. Such contacts are predominately, but not solely, channelled through trade associations.

The company cooperates with both law firms and think tanks when confronted with highly technical dossiers, such as those on data protection. ${ }^{721}$ The data protection reform that was proposed by the Commission in 2012 was of high importance for SuperFit and it was important to both fully understand the proposed reforms as well as to take its own position on it. Thus, a law firm was contacted in order to obtain insight into this dossier.

All in all, SuperFit appears to have an established network with political institutions and certain actors of civil society. When establishing contacts, the general preference of the firm is for downstream networks, seeking contact with a wider range of partners and alliances and officers at a lower level ${ }^{722}$ - however, the targeted level does escalate depending on the importance of the dossier and on the business impact involved.

\subsection{Communication Tools}

Position papers are the main tools of communication for SuperFit. Position papers are usually twopages long, sharp and address all matters at stake. Once approved by the overall head of regulatory affairs, position papers are not modified according to the political institutions they are submitted to.

SuperFit articulates its interests and pleas through trade associations, and Seldia plays a particularly important role in this respect. The public affairs managers are not authorised to speak with the press.

\subsection{Monitoring Legislation and Business Intelligence}

SuperFit monitors a number of legislative areas, mainly consumer law, dispute resolution and contract law. Due to the nature of SuperFit's products, food safety regulations, food labelling, and the laws on food supplements and claims are closely followed.

A great deal of monitoring succeeds through the internet: websites such as the Legislative Observatory of the European Parliament, that of the European Council, European Voice, The Midday Expressand The EU Observer are followed on a daily basis. For more specific, food-supplement related matters the EU Food Policy website is visited frequently. Information is also obtained through personal contacts with assistants of MEPs, permanent representatives and officers of the Commission.

\footnotetext{
${ }^{721}$ The European Commission proposed a comprehensive reform of the EU's 1995 data protection rules to strengthen online privacy rights and boost Europe's digital economy on January 25, 2012.

${ }^{722}$ Gueguen, D., European Lobbying, p. 83-84.
} 
The public affairs managers prepare a weekly report on legislative proposals. Analysis of the obtained information is carried out collectively, as the public affairs professionals of the firm have weekly discussions on how to proceed with the relevant issues.

\subsection{Intervention}

When lobbying the political institutions, the two main institutions that are approached are the European Parliament and the Commission. As regards the EP, rapporteurs, shadow rapporteurs, MEPs, coordinators of political groups, certain particularly active parliament officials and group advisors are contacted. within the case of the European Commission, it is mostly the unit level which is targeted by the European Affairs Managers. Neither the Council of Ministers, nor the Economic and Social Committee are approached extensively by the firm - lobbying these institutions is predominately left to the trade associations.

When approaching officials, SuperFit tends to follow a bottom-up approach. In the initial phase, the Commission's unit level is targeted, whereas in later stages the Commission's cabinets may be contacted as well.

The Council of Ministers is generally not the main focus of lobbying, as this institution is not as open to lobbying as other institutions. The same applies for lobbying Expert Groups of the Council and Comitology Groups: these institutions are approached mostly by trade associations rather than by the company itself.

When attempting to influence the key institutions and policymakers, SuperFit always strives to provide high-quality technical input to underline and enhance its own credibility.

SuperFit intervenes mainly during the proposal phase and provides technical information to both the rapporteur and the shadow rapporteur. At all times, the corporation is especially careful to maintain a constructive dialogue with policymakers.

Another important phase within the legislative process where interventions occur is Comitology. For example, during the adoption of the approved list of health claims through Comitology, SuperFit lobbied actively during the EP's scrutiny of the proposed instrument. Regulation (EC) No 1924/2006 on nutrition and health claims made on foods required the adoption of an approved list of health claims and food labelling. The said list of 222 permitted health claims approved by the Commission was eventually adopted on May 12, 2012. ${ }^{723}$

${ }^{723}$ European Commission Press Release, European Commission adopts landmark list of permitted health claims, Reference: IP/12/479, 16 May 2012 


\subsection{Lobbying Strategies}

Lobbying strategies of SuperFit can be categorised as either reactive or proactive, depending on the issue at stake.

A more reactive lobbying strategy was applied following the adoption of the Regulation on nutrition and health claims made on foods by the Council and Parliament. The manner in which the Regulation ${ }^{724}$ was implemented was not what was expected by the industry and therefore the corporation took reactive steps. Besides the parliamentary questioning of the stringent measures, SuperFit also encouraged a number of MEPs and academics to debate the issue of the rejection of health claims with both the European Commission and EFSA.

SuperFit usually prefers proactive lobbying, however. A proactive lobbying strategy was taken on by the industry regarding the recently adopted consumer rights directive. Led by Seldia, the industry had been advocating the interests of the direct selling sector from the earliest possible stage and was delighted with the initial Commission proposal. Despite the ongoing lobbying and continuous efforts, however, the eventually adopted directive was highly disappointing for the sector.

\subsection{Coalitions}

SuperFit is a member of a number of trade associations which include Seldia as well as various nutrition associations and other EU representative groups.

Membership in trade associations does enhance the lobbying powers of SuperFit. While Seldia tends to be more political and advocates for the interests of the direct selling sector towards political institutions, nutrition trade associations provide more technical rather than political input in comparison to the direct selling trade association. There are also trade associations -such as AmCham EU- whose main strength lies in providing networking opportunities with EU officials rather than direct lobbying.

Ad hoc industry platforms are formed for specific issues, mostly when dealing with food law. These task forces usually have a considerably more hands-on approach and are swift in organising how to access the political institutions (mostly the European Parliament), compiling a position paper and sending delegations to Strasbourg.

\footnotetext{
${ }^{724}$ The aim of this Regulation is to ensure that any claim made on foods' labelling, presentation or marketing in the European Union is clear, accurate and based on evidence accepted by the whole scientific community.
} 


\subsection{Case Study 3: Pinkify - Lobbying Through a Third Party ${ }^{725}$}

\subsection{The Firm's Public Affairs Management}

Pinkify has assigned a consultancy to carry out lobbying tasks in Brussels. The consultancy focuses on the delivery of expert strategic communication and public affairs services to a variety of clients in the private and public sectors.

Although the company only has a small public affairs staff of three throughout the world, Pinkify's constant business expansion in Europe has called for the need to commission a consultancy to handle the firm's government affairs in the capital of the EU.

The consultancy provides intelligence, facilitates bilateral meetings with key European institutions, represents Pinkify in trade associations and executes targeted lobbying campaigns for the corporation. Based on policy tracking, the consultancy makes recommendations to Pinkify's higher government affairs management and cooperates in building an advocacy strategy for the firm.

In principle, Pinkify advocates its interests in Brussels mainly through trade associations, and lobbies directly only when the dossier concerned is of crucial importance.

\subsection{Network}

Building relationships in Europe is a must for Pinkify. For one, there is a significant potential of growth in several European Member States for the company.On the other hand, however, there is a relatively low level of awareness of both Pinkify as well as the direct selling channel. Thus, in order to be better able to get its individual point across to European policymakers, Pinkify is becoming more active in networking with key stakeholders in the Brussels political arena.

The main focus of relationship building, besides the obvious European political institutions, is key permanent representations and missions, interest groups such as the direct selling industry representation, product-related trade associations and national trade associations, as well as BEUC, the European Consumers' Organisation.

\subsection{Communication Tools}

Position papers are issued only very occasionally by Pinkify, as it is rather the trade associations' position papers that are actively contributed to and commented on as a main rule. Own events for the purposes of lobbying are not organised. Public relations work is also predominantly done through trade associations.

\footnotetext{
${ }^{725}$ The case study is based on the interview conducted with the Consultant of Pinkify on 17 December 2013 in Brussels.
} 


\subsection{Monitoring Legislation and Business Intelligence}

Legislative monitoring and intelligence is one of the main services the Brussels consultancy provides Pinkify with. The consultancy monitors and tracks policy developments and makes recommendations as to what the next steps should be to Pinkify's higher management. The watch list is reviewed every 6 months which is when the list of issues to be monitored is (re)defined.

At present, the consultancy monitors three tracks of policy: product-, distributionand mostly trade related issues. Currently the main focus is on product-related issues to ensure compliance, as well as to aid departments of product development and research. The consultancy frequently alerts Pinkify of product-related matters.

In the course of legislative monitoring concerning the distribution channel, consumer rights legislation (e.g. the Consumer Rights Directive) and competition law (e.g. the Unfair Commercial Practices Directive) are held under close scrutiny.

The third category of tracking entails other, mostly trade-related issues such as free trade agreements, trade relations between the EU and third countries like the Ukraine and customs issues. Intelligence is also gathered through various trade associations.

\subsection{Intervention and Lobbying Strategy}

Where possible, Pinkify prefers to provide input into the policy-making process indirectly through trade associations, as mentioned earlier. However, concerning certain dossiers that are of primary importance for the corporation about which Pinkify wants to express an individual position and/or it has a position different from that of its trade associations, Pinkify, together with its consultancy, takes a more proactive approach.

In the course of direct action, the European Parliament, the Commission and the Council - through the Permanent Representations - are all approached. Members of the European Parliament who either present an important market connection (to key markets such as Poland or Germany) and/or are active on the respective issue are targeted in the first place. Meetings with assistants of Members of the European Parliament are also held often, should the MEP in question not be available.

When approaching the Commission, it is mainly the heads of unit and policy officers who are targeted. More technical issues are discussed with technical policy officers.

Permanent Representations are contacted in Brussels, should a local matter escalate to the European level; furthermore, representations of key markets are also met with regularly. This is however not a two-way approach, as there are not many meetings in national capitals. Pinkify does not tend to have local public affairs staff throughout the EU, rather policymakers at national levels are mostly lobbied through the permanent representations. When Pinkify does intervene, it also approaches other stakeholders 
such as BEUC, the European Consumers' Organisation, or Pinkify's national representations.

In terms of strategy, Pinkify prefers to be as proactive as possible. Yet, depending on the issue at stake, the strategy may be reactive as well. In the event that an issue comes up in the course of the monitoring or a key legislative proposal is made, the consultancy makes recommendations for immediate and direct action. The exact strategy is worked out and decided upon jointly with the company's higher government affairs management. The strategy is then executed jointly on the ground.

\subsection{Coalitions}

Trade associations play an integral role in Pinkify's interest representation. Besides the intelligence provided by trade associations, the majority of lobbying is done through various interest groups.

Pinkify is no longer a member of the main European product-related trade association but is a member of national trade associations both on the product side and on the direct selling side.

The trade associations representing Pinkify's national interests have varying degrees of efficacy, while the US-based product-related trade association which Pinkify is a member of is considered to be a very useful source of information and influence.

The perception of Seldia, the European Direct Selling Association, is slightly more ambivalent. On the one hand, Seldia does advocate the direct selling industry's interests and is adept at organising public events, but on the other hand Pinkify has detected certain deficiencies in the flow of information. Perhaps because Pinkify is represented by a consultancy, Seldia has at times proven reluctant to provide the consultancy with all of the information other corporate members receive.

All in all, as a main rule, Pinkify lobbies through its trade associations and takes direct action only when the importance of the dossier demands individual lobbying and/or in the event that Pinkify intends to distinguish itself from other actors within the industry. 


\subsection{Case Study 4: Corporate Lobbying Strategies of $A C N^{726}$}

\subsection{The Firm's Public Affairs Management}

The management of the firm's public affairs in Europe falls under the responsibilities of Paul Gagnier, ACN Europe's General Counsel. The General Counsel monitors legislation and serves as the lead contact for European public affairs issues. He is the person representing the corporation in all trade associations be it a Brussels or a local trade association. As most lobbying activities are conducted through trade associations, ACN Europe does not tend to engage in direct lobbying actions. For the purpose of public affairs management, the general counsel reports to the Executive Vice President (EVP) of Global Development. Policy decisions are made jointly by Paul Gagnier and the EVP of Global Development.

\subsection{Network}

A self-confessed "small player" in the political arena, ACN Europe does not lobby directly and, therefore, it does not approach government agencies. However, as ACN Europe's headquarters are located in Amsterdam, the corporation maintains contacts with Dutch government officials despite the fact that the Netherlands market is a small one.

Trade associations are one of the most important contacts of the corporation. ACN Europe is a corporate member of Seldia and aims to become a member of all of Seldia's national trade associations where the company is present. The other major trade association in which ACN holds membership is AmCham EU, which provides networking opportunities as well as an important source of business intelligence. ACN Europe was a member of the European Competitive Telecommunications Association, but since this trade association did not meet the firm's needs on a pan-European level, the firm stepped out.

The corporation also cooperates with law firms that supply regulatory updates and policy evaluations.

Think tanks, NGOs and the press are not contacted and are thus not members of the firm's network for the purpose of lobbying and managing public affairs.

\footnotetext{
726 The case study is based on the interview conducted with ACN General Counsel Paul Gagnier on 23 August 2012 .
} 


\subsection{Communications}

The firm submits position papers to political institutions only very rarely. However, ACN is very active and provides input when Seldia and AmCham compile position papers. Press releases are not published in order to support lobbying activities, nor are lobbying campaigns conducted. ACN only communicates with the media to improve its public relations, hence the press is not an integral factor in managing public affairs.

\subsection{Monitoring Legislation and Business Intelligence}

Given that the firm offers telecommunication services, all legislation related to this sector is closely monitored. Additional areas of monitoring include direct selling, consumer protection, consumer redress, unfair commercial practices and contract law.

Legislative issues are followed through a number of channels. Aside from relevant legislative observatory websites, trade associations and law firms provide valuable information and analysis on public affairs. The website of BEUC, the European Consumer Organisation, is followed on a regular basis in order to get updates on relevant policy issues.

The audience of the reports depends on the subject matter. Policy level issues are being addressed to both the EVP of Global Development and the local management. If the issue has a business impact, but the decision required is more of an operational nature, the matter is consulted with the appropriate business unit.

\subsection{A collective Lobbying Strategy}

As indicated above, ACN does not lobby directly at the EU level. Instead, it relies on trade associations when representing its interests. Allegedly, ACN Europe does more lobbying at national levels and especially in the field of telecommunications services and not so much on direct selling.

Furthermore, as the bigger telecoms providers tend to advocate for the interests of the telecommunications sector rather effectively, ACN Europe does enjoy the benefits of the industry's lobbying without directly contributing to it.

\subsection{Coalitions}

ACN Europe is a member of Seldia, Seldia's national associations and AmCham EU. Membership in these trade associations is crucial for the company for a number of reasons. Seldia being the smaller advocacy group, it can really focus on its members' interests and lobby for the direct selling sector at the EU level. On the other hand, because it represents a smaller segment of the consumer economy, Seldia has to speak loudly in 
order to be heard. Nevertheless, the recent positive changes in the association -such as the joining of the French and Italian national associations and more efficient lobbying in Brussels- have strengthened Seldia's position and lobbying powers. On the other hand, because every other direct selling company sells cosmetics, food supplements or household products, ACN Europe only benefits from Seldia's work regarding direct selling matters and consumer issues.

AmCham EU is very effective in promoting its agenda and provides its members with high level analyses on relevant dossiers. Nevertheless, as AmCham's membership is considerably wider than that of Seldia, the division of its members is also bigger. As a result, AmCham has to represent a wider range of opinion and hence more focus is laid on general issues such as consumer affairs. ACN is a member of both AmCham EU's Information- and Technical Affairs Committee as well as the Consumer Affairs Committee.

ACN Europe has not yet had the opportunity to participate in ad hoc industry platforms, but would do so, if the opportunity arose.

\subsection{Case Study 5: Corporate Lobbying Strategies of Kyani ${ }^{727}$}

\subsection{The Firm's Public Affairs Management}

Due to the fact that Kyani is currently too young of a firm, there is no designated staff to handle external affairs - public affairs are mainly dealt with by Janne Heimonen, Managing Director for Europe, who is responsible for meeting with various local lawyers, national direct selling associations and Seldia. In terms of reporting, the European managing director reports to the global CEO in general.

\subsection{Network}

As a young and developing new company, Kyani does not engage in individual lobbying activities, and it has yet to build its own network with EU institutions and national governments.

At this point, trade associations are the most important agents of interest representation for the firm both nationally as well as at the EU level. Kyani became a corporate member of Seldia in 2013 and has joined a number of national direct selling associations and American Chambers of Commerce.

\footnotetext{
727 The case study is based on the interview conducted with Kyani Managing Director for Europe, Janne Heimonen on 31 October 2013.
} 
The corporation also cooperates with law firms occasionally, should legal disputes arise. On one occasion, Kyani did rely on a law firm to lobby in a national product safety-related matter individually. The case concerned an Estonian measure regulating vitamin contents in food supplements against which the company raised a complaint with EFSA, the European Food Safety Authority.

Think tanks, NGOs and the press are not contacted and therefore do not constitute the firm's network for the purpose of lobbying and managing public affairs.

\subsection{Communications}

Communications are not used as an advocacy tool by Kyani, nor are position papers submitted individually by the firm. The press and PR firms are only contacted to conduct product-related communications.

\subsection{Monitoring Legislation and Business Intelligence}

Kyani monitors legislation to ensure compliance, first and foremost. To that end, consumer law, fair trading law (pyramid scheme regulations and marketing law), product related legislation and regulations concerning micro-and small businesses (in particular, tax laws) are monitored closely.

\subsection{A collective Lobbying Strategy}

As regards interest representation at the European level, Kyani relies on Seldia exclusively. As the company is still small and does not have designated public affairs staff, its contributions to Seldia's daily work (i.e. defining positions or producing position papers) are limited.

Kyani on the whole sees its Seldia membership as an asset and is generally satisfied with the output of Seldia's efforts. The enthusiasm demonstrated by Seldia is praiseworthy and the trade association is delivering good results, especially in light of the size and the questionable reputation of the industry, although the domination of the large international companies may at times result in the formulation of imbalanced views within both Seldia and the national trade associations.

Self-regulation through Seldia's Codes of Ethics provides a useful input on the field. The company's compliance department uses them as guidelines of conduct and utilises them in the training of distributors as well. In fact, it is of crucial importance that distributors are aware of the Codes and they have also shown a tremendous interest towards them. Furthermore, in countries where direct selling associations are strong, such as in Sweden, demonstrable adherence to the Codes has changed the perception of the 
direct selling industry and has contributed to building positive relations with the media and NGOs.

On the other hand, it would be beneficial if Seldia lobbied more on national issues as its activities currently seem incomplete in this respect. Moreover, Seldia needs to get more involved in legislative lobbying. The romotion of entrepreneurship is an effective advocacy aim which opens many doors, yet women entrepreneurship may be too easy of a target and it creates a risk of not discussing more substantial issues related to starting up or operating micro- and small businesses. With respect to entrepreneurship in particular, Seldia could work on national issues such as the taxation of SMEs or red tape in various Member States in an effort to tackle the problem of tax inequality.

Lastly, the split is seen as a huge loss for the industry. It means a loss of credibility, power and resources but restoration of cooperation is not likely in the near future.

\subsection{Discussion of Empirical Findings}

\subsubsection{Direct Selling Advocacy as a Rational Choice}

The analysis of the direct selling industry's strategic interests in relation to four lobbying dossiers -the Consumer Rights Directive, the pyramid scheme regulation, selfregulation and entrepreneurship promotion- and the results of the empirical research through the public choice theory offer relevant findings from a political sciences perspective. The current section attempts to combine findings of the legal and empirical research into the direct selling industry and interpret these revelations by placing them into the frame of reference of the previously discussed (see section 7.3.) public choice theory, the theory of collective action and the theory of access.

According to the pubic choice school, players in the political arena act as rationally as they would act in the marketplace and strive to maximise their profits and promote their own interests. In an effort to influence policy outcome, the political agenda or policymakers' perception in a way that maximises utility, interest groups organise themselves and engage in lobbying activities. Although criticised for not taking social norms and community values into account sufficiently, the public choice theory appears to provide the most plausible explanation for the assessed direct selling industry advocacy actions.

The overall evaluation of the industry's and other stakeholders' position papers, press releases and other advocacy materials appears to reflect the core finding that lobbyists are in fact after the interests of their beneficiaries and not those of the general 
public. Moreover, the public consultation and institutional mechanisms of European Union policymaking are also designed to include a variety of interests into the public discourse and legislative procedure - the European Commission even subsidises certain public interest groups such as the European Consumer Organisation, BEUC, securing a pluralistic system of interest representation.

What must also be highlighted at this instance is that the assessment of the two direct selling industry groupings' positions after the industry split have not indicated any substantial differences in the strategic interests of the parties. Rather, the empirical findings have pointed towards the fact that the split was due to the disproportionality of the original FEDSA voting system and members' opinions, wherefore the two pressure groups' positions will be collectively referenced as the "direct selling industry interests" in the present section.

The assessment of two concrete political deliberations preceding the adoption of two pieces of legislations (the Consumer Rights Directive and the pyramid scheme definition in the UCPD) has revealed that the procedure was more of a bargaining procedure than a collective effort to find the "common good" through extensive political discourse. Similarly, aspirations to set the political agenda and to shape policymakers' perceptions were meant to serve the interests of the direct selling industry through the promotion of entrepreneurship and self-regulation.

The case study on the industry advocacy concerning the Consumer Rights Directive has revealed that a strategic interest advocated by the industry (in unison with the business community) was trade liberalisation through the full harmonisation of European consumer law. Contributions of the industry advocacy from as early as 2001 called for the abolishment of trade barriers and the harmonisation of the regulatory framework in order to promote the interests of both pan-European direct selling corporations as well as the small- and medium enterprises the industry very much relies upon. By doing so, the industry -alongside with the European Commission- was practically challenging a delicate political equilibrium struck in the eighties by Member States as an expression of their will to establish a common European consumer policy, but not necessarily the internal market.

The direct selling industry was clearly interested in the liberalisation of trade to both increase profits through extended trading opportunities as well as to cut the deadweight costs of protectionist regulations blocking trade in various Member States. Deadweight costs relating to protectionist Member State measures were in particular those relating to the administrative costs of having to comply with 27 legal regimes as well as those stemming from the direct selling trade barriers which provided an additional incentive for the industry to apply pressure to change. 
The industry's pleas for market integration and full harmonisation of a wider terrain of consumer law have chimed with the European Commission's intentions; as the promoter of overall European societal interests, the European Commission was in favour of the achievement of economic growth through a greater degree of market integration. An additional drive in the revision of the consumer acquis and a good example of Down's model of rational politicians at the time was the Consumer Protection Commissioner, Maglena Kuneva, who was once described as 'an economic liberal, who was determined to reconcile Europeans with competition and free markets through the promotion of consumer rights and, through the wise choice of overall targets, has managed to achieve a high profile as an EU policymaker'. ${ }^{728}$ Kuneva's activism and personal ambition has undoubtedly contributed to the initiation and the adoption of the new Directive and the revision of the respective aspects of consumer law.

Conclusively, the industry's contributions in the course of the agenda-setting stage and the drafting phase were welcomed and were reflected in the initial Commission proposal.

The reduction of protectionist measures and the introduction of full harmonisation were, however, strongly opposed by the majority of Member States and consumer movements as a result of which strong competition between various interests and pressure groups for the redistribution of regulatory power emerged. Member States were namely neither interested in giving up more of their sovereignty and legislative power, nor were they keen on introducing politically unpopular measures that were to cut back on consumers' rights. Consumer groups, on the other hand, did not want to see a reduction of consumer rights in Member States that had secured a high level of protection and were thus promoting mixed or targeted harmonisation.

The result was a difficult compromise that meant the relocation of the regulatory power, albeit in a considerably narrower field than originally planned by the European Commission. In line with the Becker's theory, as a result of the compromise, there were neither clear winners nor clear losers of the bargaining procedure - it was a modus vivendi or a new political equilibrium acceptable to both sides whereby both sides had to make concessions. A uniform set of rules was introduced for direct selling and distance selling consumer contracts only, instead of the intended full harmonisation of the consumer acquis (or contract law for that matter), but even that conceded certain derogations to satisfy Member States. Protectionist national measures that do not fall under the scope of the permitted minimum harmonisation clauses are expected to be lifted, how-

728 The Economist, A Commission Report Card, 24 September 2009, http://www.economist.com/node/ 14505501 (last visited 17 June 2015) 
ever, providing further evidence to Becker's concept as regards the temporary and incomplete nature of protective measures. The direct selling industry is likely to lobby for the abrogation of these barriers to trade and the European Commission is likely to be receptive to these pleas as the executor of European law and the promoter of integration.

The second dossier on the regulation of pyramid schemes serves as an example of how a small and well organised advocacy group with concentrated interests has the capability to achieve legislation that favours the sectorial interest group. As discussed earlier in detail, the pyramid scheme and MLM regulation is a very specific aspect of unfair competition law, the shaping of which was vital for the direct selling industry. As found in chapter IV, the direct selling industry was aiming to get a generic pyramid scheme definition alongside the deregulation of MLMs in order to allow for the legitimate functioning of a wide array of compensation schemes and multi-level marketing business structures.

Although the VIEW report written by academia upon the request of the European Commission suggested a more stringent and very specific regulation of pyramid schemes, and as such would have served the interest of the "general public" (but most certainly, the interests of micro- and small enterprises that have recently switched from a consumer status to a direct seller status) to a greater degree than that put forward by the direct selling industry, the concentrated lobbying efforts of the industry advocacy bore fruit. Given the lack of any real opposing interest group, there was no bargaining procedure that had to take place - the pyramid scheme definition and the deregulation of MLMs, as suggested by the industry, were adopted by policymakers thus rendering the direct selling industry the winner of the zero-sum political game. This case study also serves as an example of the distorting effects of lobbying and how a particular interest group has managed to influence a macroeconomic decision fully to its advantage, irrespective of the interests of small- and microbusinesses, thereby contradicting the critiques of the public choice theory for ignoring community spirit and values.

Since the adoption of the Unfair Commercial Practices Directive, the industry advocacy has been successfully influencing the Commission's political agenda in defence of the status quo or, in other words, the revision of the pyramid scheme regulation in spite of the emergence of competing interests in this terrain. The "tyranny of the status quo", as Becker put it, ${ }^{729}$ has thus far prevailed and the revision of the UCPD or the pyramid scheme definition has been avoided, despite recently emerging opposition by BEUC and partly also from within the direct selling industry itself. While, as presented in chapter

\footnotetext{
${ }^{729}$ Becker, G., 'Competition Among Pressure Groups', Vol. XCVIII The Quarterly Journal of Economics, No. 3 (1983), p. 371-400., p. 381.
} 
IV, BEUC and a direct selling company have called for the extension of the pyramid scheme regulation, the direct selling industry advocacy (both Seldia and DSE) stand united in claiming that there is no need to revise the definition as it is adequate and that the industry's engagement in self-regulation offers ample protection.

Self-regulation, the third analysed lobbying dossier, is perhaps the most interesting to assess in light of the public choice theory. While it was found that globalisation does catalyse standardisation and market integration, there were a variety of potential motivations behind self-regulation described, ranging from moral commitment to pure deception. In the previously assessed case of direct selling self-regulation (chapter V), it was found that the market abuses and the resulting public condemnation of the industry was what necessitated the introduction of private regulation in the first place. Although the reason for the introduction of the Codes of Conduct towards consumers, and then later towards direct sellers, was clearly self-interest under external pressure, it was found to have regulated the industry to some extent by ensuring an increased level of legal compliance. The overlap of the industry's self-interest with public interest in terms of legal compliance and adherence to fair trading standards has secured credibility for the self-regulatory endeavour. In this respect, the European regulation of industry codes of conduct and their legally binding nature considerably increase the value added by industry codes.

Driven by self-interest, self-regulation is a tool serving the purpose of influencing the perception of the direct selling industry in the eyes of the general public and policymakers. Membership in self-regulatory bodies is a quasi-trust mark indicating the trustworthiness of its members towards consumers, which enhances commercial interests. However,, as was indicated, it is also a frequently used lobbying tool. Self-regulation is generally amongst the main arguments the industry will bring forward against the introduction of stricter rules, as was the case in the course of the consultation mechanism in preparation for the compilation of the Commission's Report on the Application of Directive 2005/29/EC on Unfair Commercial Practices. In its response to the Commission consultation, Seldia explicitly stated that it is a strong supporter of the UCPD's pyramid scheme definition, as it deems it an adequate method of distinction between fraudulent schemes and legitimate businesses. Moreover, because the industry is engaged in selfregulation and the national direct selling associations are required to abide by the Codes which explicitly prohibit the operation of pyramid schemes, the industry was opposed to the revision of the pyramid scheme definition. ${ }^{730}$

\footnotetext{
${ }^{730}$ Seldia's responses to Report on the application of Directive 2005/29/EC on Unfair Commercial Practices (UCPD) Questionnaire for Stakeholders, p. 5 http://www.seldia.eu/images/pdf/Seldia_response_UCPD_Questionnaire.pdf (last visited 17 September 2014)
} 
The promotion of entrepreneurship as a lobbying dossier was found to be aimed at profit maximisation both literally, through the direct promotion of the business structure in order to attract more small businesses as direct sellers, as well as indirectly, by way of adjusting the industry image and narrative to the prevalent economic policies. The assessment of the entrepreneurship lobbying dossier was an example of the way lobbyists shape policymakers' perception of the direct selling industry as a whole, attempting to bring it in line with popular policy objectives that promote entrepreneurship as a means to combat the crisis. What makes the entrepreneurship lobbying dossier successful and appreciated by policymakers is that the lobbyists have found an overlap of the industry's and policymakers' interests. By presenting a positive narrative of the direct selling industry tailored to the contemporary entrepreneurship policy, industry lobbyists can better promote the industry image but can, at the same time, also provide policymakers with a concrete and tried means to increase entrepreneurship to offer their constituencies. This can also be seen as a clear exchange between the industry lobbyists and politicians: industry lobbyists provide a political solution, information and a platform for politicians to promote themselves and their political convictions individually in exchange for increased institutional access and popularity.

The two main themes of the dossier, as described earlier, are the promotion of women entrepreneurship -a safe and uncontroversial issue that not only strikes cords but is also fully in line with the Commission's policies and has gained significant political support by Members of the European Parliament as well- and academic research on entrepreneurship. While the female entrepreneurship campaign is orchestrated by Seldia, the entrepreneurship research program is funded by Amway only, allowing the rest of the industry to "freeride", i.e. benefit from the advocacy of this one company.

\subsubsection{Collective Action, Group Size Theory and Individual Lobbying of Direct Selling Advocates}

Rational and self-interested actors of the political scene engage in individual and/or collective action in order to further their interests. Bouwen has found that there are three variables that determine firms' organisational forms of lobbying activities: the size, the economic strategy and the domestic institutional environment of the firm. ${ }^{731}$

The size of the corporations is decisive in terms of the resources a firm has to invest in lobbying activities as only the largest firms are in a position to establish a permanent representation in Brussels. Less resourceful companies participate in collective action,

\footnotetext{
${ }^{731}$ Bouwen P., 9 Journal of European Public Policy, Issue 3 (2002), p. 365-390., p. 373-375.
} 
through European trade associations or industry platforms, while an intermediary solution is the involvement of a third party such as a consultancy that allows direct political representation tailored to the needs of the firm but without having to establish a costly permanent Brussels representation. ${ }^{732}$

Economic strategies of firms are the second variable that influences firms' choices of political strategies. Large multinational corporations have strategies that concern the entirety of the European market and are therefore interested in influencing the EU's legislative and political framework. Conclusively, these firms have Brussels offices that allow company representatives to have direct contact with policymakers on a permanent basis. National niche players, on the other hand, are more focused on domestic markets. Yet, with the increased importance of EU legislation in Member States' market regulation, there is also a distinctive need for these firms to follow Brussels politics and policymaking, mostly through membership in European trade associations. ${ }^{733}$

The third aspect to be assessed is the domestic institutional environment of the firm. For one, the corporation and the extent to which the state administration controls the economy and, secondly, the strength of national trade associations and national lobbying culture.

Strong state control reduces incentives for political action at EU level, whereas private actors' close cooperation with state administration is likely to give them a higher degree of access to EU policymakers. ${ }^{734}$

In the absence of strong and effective national trade associations, firms might be compelled to lobby national governments as well as to escalate matters to European level. If lobbying is perceived positively by the respective Member State's society, the company is more encouraged to advocate its interests both at national as well as European level. ${ }^{735}$

Corporations that intend to be active in the European political arena have to weigh the three variables in order to establish their political strategies. As a result, smaller firms often choose a solely collective course of action, as we have seen in the case of ACN Europe and Kyani, whereas larger firms have the possibility to choose a number of lobbying forms, allowing the companies to establish a multi-channel lobbying strategy.

\footnotetext{
${ }^{732}$ Ibid., p. 373-375.

${ }^{733} \mathrm{Ibid}$., p. 373-375.

${ }^{734} \mathrm{Ibid}$., p. 373-375.

${ }^{735}$ Ibid., p. 373-375.
} 


\subsubsection{Collective Action}

Case studies and interviews with direct selling corporate representatives have revealed that companies typically engage in two main types of collective action. Firstly, companies are members of various trade associations and, secondly, they have a tendency to participate in ad hoc industry platforms.

Trade associations of which direct selling corporations are typically members are organised based on national affiliation (the American Chamber of Commerce), sectorial interests (Direct Selling Europe and Seldia) or are product-related (Cosmetics Europe or nutrition trade associations).

The comparison of AmCham EU and the direct selling trade association(s) from an advocacy perspective is particularly interesting.

The American Chamber of Commerce is a considerably bigger organisation representing a much wider array of interests than the sectorial direct selling associations. Conclusively, it can make its voice heard more easily in the Brussels political arena, but it is less capable of representing specific interests and is therefore the trade association that members tend to predominantly use to influence the political agenda rather than to advocate distinct direct selling industry-related issues.

Looking at the direct selling pressure group(s), the assessment of two legislative lobbying dossiers: the consumer rights advocacy and, especially, the pyramid scheme definition, has underlined the validity of Mancur Olson's theory concerning the increased efficacy of small interest groups' representation of concentrated interests (for a more detailed discussion of the Olsonian theory see sub-section 7.3.2.). In both instances, the interests of the group were very clearly defined which allowed the industry lobbyists to focus on these narrow fields exclusively.

A particularly fitting example of the Olsonian theory is the case of the pyramid scheme definition/MLM deregulation lobby, whereby the collective goal of the industry was very clearly outlined and a highly concentrated effort eventually led to a favourable outcome for the direct selling industry. It was previously described in chapter IV how precisely the industry's preferred legislative outcome had been determined and subsequently, how intensive and coordinated the industry advocacy's efforts were to achieve the desired goal. The legal definition of the pyramid scheme regulation and the deregulation of MLMs were of key importance for the entire direct selling industry wherefore FEDSA's lobbying was aided by the World Federation's advocacy as well as Amway's additional support. The well-orchestrated campaign that brought together the introduction of the American federal- and state regulations and case law (as an existing best practice), the FEDSA advocacy and a reputable law firm's comparative analysis of the 
European legal regimes (as sponsored by Amway) has proven successful for the industry but has also led to distortions from a societal perspective. While the industry was pleased with the outcome as the current regulation is not restrictive of multi-level marketing practices, it was found to be incomplete and lacking of private law protection to small- and micro-businesses.

From an organisational perspective, there are a number of selective incentives (rewards for collective action) that encourage participation of members in the direct selling pressure group(s).

Firstly, members receive information and business intelligence from the trade associations, which is especially valuable for those corporations that do not have a permanent representation in Brussels. Information and business intelligence is paramount in Brussels advocacy - obtainment of information at the earliest possible stage not only allows lobbyists time to prepare a strategy but it also secures a greater potential for intervention. That is, the sooner the lobbyist learns of a planned proposal, the more chances he or she has to exert influence upon it. Timely information is power. Interestingly, in the course of the interview process, the advocator of Pinkify, the Brussels-based consultancy representing the interests of the company, did claim that Seldia did not always share all information with them, which underlines the importance and the selective nature of this type of incentive. For reasons of competition, the direct selling trade association appears ungenerous with the information distributed to a consultancy, despite the fact that it actually represents a direct selling member corporation.

Secondly, the neutralisation of political messaging is a very important incentive for direct selling corporations to engage in collective action - firms' lobbyists do not talk to the press at all. While corporations in general do not issue individual press releases as a lobbying tool, direct selling corporations are especially cautious with communications due to the industry's controversial reputation. Instead, they articulate their interests and pleas through trade associations, which have a particularly important role in this respect. To put it differently, trade associations are the shields direct selling firms use in an attempt to both protect themselves and to get their messages across to policymakers.

Thirdly, as both direct selling pressure groups act as self-regulatory bodies as well, members of the associations are signatories to legally binding codes of conduct which increases their credibility towards policymakers and the general public.

Fourthly, pressure groups are also platforms where competing companies have an opportunity to form a business community, sharing information and best practices with each other. Trade associations have also been claimed to be the instances through which contacts towards civil society (such as to consumer movements) are predominantly (but not exclusively) channelled through. 
Fifthly, and perhaps most importantly, members define and enjoy the benefits of direct selling advocacy - both in the strict sense of legislative lobbying as well as the reputational benefits of Seldia's extensive PR campaigns on entrepreneurship. Members of Direct Selling Europe are clearly the free riders of Seldia's and Amway's entrepreneurship promotion campaigns. By focusing solely on legislative lobbying, Direct Selling Europe and its members do not organise events or promote the industry through grandiose PR actions, yet they benefit from their competitors' actions. In terms of legislative lobbying, direct selling corporations (even those that also tend to engage in individual actions from time to time) have all claimed to have entrusted Seldia with the task of advocating the industry's position concerning the Consumer Rights Directive. Similarly, public records have been found from Direct Selling Europe's lobbying activities in connection with the same dossier and only the largest DSE member company, Vorwerk, appears to have lobbied individually, based on the publicly available position papers (which does not exclude the possibility that other companies took individual actions, albeit perhaps not publicly).

The main reason for the industry split, as brought forward by Seldia, was connected to selective incentives. Given the disproportionate distribution of voting power and, thus, the weight of opinion in the determination of direction and issues within the original pressure group, FEDSA, certain (predominantly sizeable) members left the organisation. Those that left have either pursued individual action or have contributed to the establishment of an alternative advocacy group, Direct Selling Europe, which secured them a greater degree of influence upon the common issues both in terms of lobbying as well as in the self-regulatory aspect. As a result, there are two separate direct selling pressure groups in Brussels that have a homogenous membership with aligned interests. Nothing in the substantial assessment of the lobbying dossiers has suggested the existence of major differences in the industry groupings' strategic interests, nor have the interviews with the industry representatives revealed disagreements over preferred policy outcomes or advocacy objectives. Although actions of the "heretic members" appear to be very much in line with the axioms of the public choice theory, providing a further example of rational players acting purely as their self-interest dictates and not according to the interests of the business community as a whole or other altruistic values, the split has landed the direct selling industry advocacy in Europe in a classic prisoners' dilemma-type situation. The common interest of the community as a whole and both lobbying groups would be to cooperate, however pursuit of individual rewards logically leads to betrayal. Interestingly, what observably happens in the case of the direct selling industry pressure groups is that they do cooperate in policy issues as their strategic interests dictate so. Both groups supported the full harmonisation of European consumer law 
and the abrogation of trade barriers and protectionist national measures, both opposed the revision of the pyramid scheme definition or the regulation of MLMs, both have very similar self-regulatory mechanisms in place and DSE “freerides" Seldia's PR campaigns promoting entrepreneurship. And yet, they also try to betray each other on a reputational level. For instance, Direct Selling Europe admittedly does not condone Seldia and its members' conduct and publicly refers to their reputational shortcomings and business models that have been brought to justice multiple times. The reason why the status quo and the otherwise condemned industry split could and can be maintained is precisely because the two pressure groups do cooperate in the representation of their members' interests which are largely homogenous and thus, in a certain sense, manage to solve the prisoners' dilemma in the way that is most efficient from the perspective of strategic interest representation and game theory.

The establishment of ad hoc industry platforms is the second main mode of collective action. Besides permanent collective action through trade association membership, ad hoc industry platforms are formed in specific issues, especially when confronted with heavy lobbying dossiers. These task forces are issue-based, have a considerably more hands-on approach and are expeditious in organising how to approach the political institutions (mostly the European Parliament), composing position papers and sending delegations to Strasbourg. A closer look at ad hoc industry platforms again validates Olson's theory on small group action. That is, a collective organised around a very specific issue can represent its case more efficiently and rapidly than the bigger organisations in which the aggregation of members' interests may take longer and is therefore less effective or practical.

\subsubsection{Individual Action}

Empirical research has revealed that corporations tend to engage in individual action in two instances: either when the importance of the dossier calls for increased advocacy action and/or in the event that the corporation does not agree with the mainstream opinion (as represented by the trade associations).

The assessment of four key lobbying dossiers has offered examples for both types of individual action. Vorwerk, a corporate member of Direct Selling Europe (with a direct representation in Brussels) has lobbied individually in the course of the deliberations concerning the Consumer Rights Directive. A close assessment of the direct selling industry's priorities in relation to the revision of the consumer acquis has revealed that, while Vorwerk agreed with and lobbied for the main strategic interests of the direct selling industry - the introduction of full harmonisation as a regulatory approach, trade 
liberalisation and the abrogation of trade barriers, a 10-day withdrawal period and the establishment of a longstop-period of the withdrawal right in the case of trader default , there were certain issues concerning which Vorwerk advocated a different individual position. Contrary to FEDSA's and DSE's positions, Vorwerk claimed that no distinction should be made between solicited and unsolicited transactions in the new directive (i.e. solicited transactions should not be exempted), timeshare contracts are to be exempted (FEDSA lobbied for inclusion) and lastly, it opposed the exemption of repeat transactions from the scope of application. It was this last element, the inclusion of repeat transactions in the CRD's scope, that was perhaps the most detrimental for Vorwerk's competitors. As Vorwerk's flagship products are vacuum cleaners that are durable items, repeat transactions are not typical for the Vorwerk businessmodel. However, competitors (such as Amway or Herbalife) that sell non-durable items (such as cosmetics or food supplements) would have been interested in the exemption of repeat transactions.

A second example of individual lobbying was noted in the European Commission's First Report on the application of Directive 2005/29/EC concerning unfair business-toconsumer commercial practices ('Unfair Commercial Practices Directive') Brussels, 14 March 2013, $\operatorname{COM(2013)~} 139$ final, which states that the two directs selling trade associations, DSE and Seldia, were both of the opinion that the revision of Item 14 of Annex I was unneccessary as the pyramid scheme definition is adequate; "a company active in direct selling", suggested that there should not be any distinction between consumers and professionals; and that Member States should be encouraged to apply the national laws transposing Annex I (Item 14) of the UCPD mutatis mutandis to businessto-business pyramid promotional schemes. ${ }^{736}$ While it is uncertain whether the corporation that made the suggestion was a member of either of the direct selling lobby groups, it was very clearly going against the common interest of multi-level marketing corporations and the mainstream opinion voiced by the two advocacy groups, thus suggesting that the individually lobbying direct selling corporation perhaps has a single-level marketing scheme and is perhaps intending to gain a competitive advantage over MLMs through individual lobbying.

The third example of individual lobbying was provided by Amway in the field of entrepreneurship promotion. As described earlier, in chapter VI, Amway funds academic

\footnotetext{
${ }^{736}$ European Commission, First Report on the application of Directive 2005/29/EC of the European Parliament and of the Council of 11 May 2005 concerning unfair business-to-consumer commercial practices in the internal market and amending Council Directive 84/450/EEC, Directives 97/7/EC, 98/27/EC and 2002/65/EC of the European Parliament and of the Council and Regulation (EC) No 2006/2004 of the European Parliament and of the Council ('Unfair Commercial Practices Directive') Brussels, 14 March 2013, $\operatorname{COM}(2013) 139$ final, p. 19-20.
} 
research on entrepreneurship annually and presents it to policymakers in the framework of European Parliament events. Pioneering entrepreneurship promotion, Amway is acting fully in line with the common interests of the direct selling pressure groups and corporations, but is also securing itself a separate platform to increase its visibility and to liaise with politicians.

Fourthly, it was also found that individual firms also lobby separately in relation to domestic issues - national advocacy dossiers of particular weight and importance are lobbied not only at national level but also through European political institutions and even by smaller players of the direct selling industry - as exemplified by Kyani or Pinkify. As Kyani's Managing Director accounted, the company has lobbied a national product safety-related matter individually, given its key importance for the company. This case of individual lobbying concerned an Estonian measure regulating vitamin contents in food supplements against which the company raised a complaint with EFSA, the European Food Safety Authority. Pinkify, on the other hand, has claimed that it approaches Permanent Representations in Brussels, in the event that a national issue escalates to European level, but key markets' representatives are met regularly too.

To sum up, individual action of individual corporations is always taken in pursuit of individual interests, be it in compliance with the common industry interests or not. While it is not difficult to understand how minority interests are best promoted through individual action, individual advocacy that is in line with the common interests are not altruistic gestures either as they always serve additional self-interests such as the reinforcement of the common position (and thus self-interest), the enhancement of individual visibility or individual networking opportunities.

Technically, individual lobbying succeeds through the accomplishment of a wide array of tasks ranging from legislative monitoring to actual intervention. Depending on the variables - resources, economic strategy and domestic context - determining the political strategy of the firms, government affairs functions are assigned to designated staff in more resourceful firms. In line with the growing weight of Brussels policymaking, the interviews have revealed that government affairs functions are drawing the increased attention of the corporations. ${ }^{737}$ SweetScent and SuperFit employ public affairs managers, Pinkify works with a consultancy in Brussels, ACN Europe has assigned the responsibility of public affairs to its Legal Counsel, while Kyani has assigned the task to the European Managing Director who oversees the operation of the entire firm. The

\footnotetext{
${ }^{737}$ In consistency with Fleisher C., Brenner S., Burke L., Dodd-McCue D. and Rogers K., 'Managing the EU public policy environment: The role of North-American MNC's corporate public and government affairs function', 844 Viessmann discussion paper series on Europe, Waterloo, Ontario: European Research Group, Wilfred Laurier University (1993), p. 1-34.
} 
fact that Kyani's European Managing Director directly deals with public affairs management indicates the strategic importance of this field. Public affairs managers representing somewhat larger companies reported to have a certain degree of discretion in managing the dossiers. A triple-layer organisational structure of public affairs management is applied by all firms except Kyani. The government affairs manager (or, in Pinkify's case, the consultant) has a supervisor to report to who in turn is responsible to the general management of the firm. It is the supervisor whose approval and permission is needed to execute the suggested actions. The corporations' lobbying strategies are thus usually the result of the joint efforts of government affairs managers and their supervisors. This organisational structure allows for relatively swift action which enhances the effectiveness of interest representation and reflects the importance of political strategy within a firm.

The establishment of contacts with officials and civil society is one of the first steps in building a lobbying strategy, especially in terms of gathering business intelligence and getting a message across. Trade associations are of crucial importance for the corporations in this respect too, especially for ACN Europe and Kyani, as the firms that do not tend to conduct individual lobbying activities in Brussels. Nevertheless, the other corporations also heavily rely on trade associations when it comes to dossiers concerning the entire industry and/or a specific product.

All corporations cooperate with law firms that supply regulatory updates and policy evaluations. When confronted with highly technical dossiers, the public affairs managers consult law firms in order to fully understand the dossier as well as to be able to develop the corporation's position on a particular issue. Hence, individual companies have external sources of technical input that can later be an important part of the expertise provided to European institutions directly or indirectly, through trade associations.

In terms of networking with political institutions, Hillmann and $\mathrm{Hitt}^{738}$ suggest that the corporation is to decide whether to formulate political strategy in response to specific, salient issues ${ }^{739}$ and to thereby adopt a so-called transactional approach ${ }^{740}$, or to use a relational approach ${ }^{741}$ and build relations across specific issues and over time in order to have ready institutional contacts to rely on, if and when a certain policy issue arises.

\footnotetext{
${ }^{738}$ Hillmann, A. J., Hitt, M., 'Corporate political strategy formulation: a model of approach, participation and strategy decisions', 24 Academy of Management Review, Number 4 (1999), p. 825-842., p. 828.

${ }^{739}$ In consistency with Buchholz, R.A., Public policy issues for management (Prentice Hall, Englewood Cliffs, N.J., 1992) and Yoffie D., 'Corporate strategies for Political Action' in Marcus, A.A., Kaufman A.,M., and Beam. D.R. (Eds.), Business strategy and public policy: Perspectives from business and academia (Quorum Books, New York, 1987), p. 43-60.

${ }^{740}$ Hillmann A.,.J., Hitt M., 24 Academy of Management Review, Number 4 (1999), p. 825-842, p. 829. ff.

${ }^{741}$ Ibid., p. 829. ff.
} 
Research has indicated that SweetScent's relations with government institutions can perhaps be characterised as transactional. Their contacts are established on a more ad hoc basis, while SuperFit shows a tendency to relate to EU institutions on a more longterm, relational basis. SuperFit has an established network with the political institutions, mostly with the European Commission. In the event that a law is being discussed, representatives of SuperFit hold bilateral meetings with specific Commission officials with which they have established contacts. It was thus found that SuperFit -in line with the general tendency of multinational companies ${ }^{742}$ - clearly favours the relational approach. The reason why SuperFit is better able to facilitate a continued and long term approach is possibly because it has a narrower product line and hence a narrower focus on policy domains ${ }^{743}$ than SweetScent. This explains why SuperFit can concentrate more on building the political capital and specialised political knowledge needed to form relationships with key policymakers ${ }^{744}$ and is therefore a perfect example of the Hillmann-Hitt institutional relationship model.

By managing information and conducting business intelligence, corporations monitor legislation, analyse risks and anticipate policy outcomes in order to be able to define the optimal lobbying strategy. ${ }^{745}$ Generally, the scope of monitoring has three main tracks: legislation relating to distribution channel-, products- and international trade are followed. Monitoring channels are also multiple. Aside from relevant legislative observatory websites, trade associations and law firms provide valuable information and analysis on public affairs.

Business intelligence, 'the capacity to obtain non-public information and analyse it so as to offer a strategic advantage in terms of anticipation, organisation, establishment, action and influence ${ }^{746}$ plays a crucial role when trying to accelerate influence on European policymakers. As mentioned above, an important segment of direct selling corporations' business intelligence is linked to trade associations -mostly AmCham EU and Seldia- but insider information is also obtained through personal contacts with assistants of MEPs, permanent representatives and officers of the Commission.

Analysis of the gathered information is achieved through multiple channels and steps. First of all, the public affairs managers attempt to assess the risk a certain legislative proposal entails for the company. In the event that the dossier or the issue at stake is of a highly technical nature, then both the firms' technical experts as well as outside

\footnotetext{
${ }^{742}$ Walker, J., Mobilizing interest groups in America (Ann Arbor: University of Michigan Press, 1991), p. 105.

${ }^{743}$ Hoskinson, R. and Hitt, M., 'Antecedents and performance outcomes of diversification: A review and critique of theoretical perspectives', 16 Journal of Management, p. 461-509.

${ }^{744}$ Hillmann, A.,.J., Hitt M., 24 Academy of Management Review, Number 4 (1999),p. 825-842, p. 830.

${ }^{745}$ Gueguen, D., European Lobbying, p. 75-79.

${ }^{746}$ Gueguen, D., European Lobbying, p. 75.
} 
experts are involved in the analysis. Trade associations and law firms play important roles not only in providing corporations with regulatory updates but also by evaluating the information and policies therein.

Lobbying strategies are defined based on the results of risk assessment and the proposal of the public affairs managers, who -if the corporation lobbies individually- are granted permission by senior officials and management to execute the proposed strategy. The relative discretion of public affairs managers or responsible actors to handle dossiers within the firms allows rather swift and effective decision-making and action.

The "preparatory" stage of obtaining information, the analysis of the attained data and the prioritisation of the firms' interests are followed by the actual intervention in the law making procedure. Individually lobbying firms apply a political lobbying strategy only, and no public records have been found of any actors deploying litigation as an advocacy vehicle.

Should the issue or business interest at stake be important enough that the firm deems it necessary to act, the corporation has to decide how to take action, whether to apply a negative, ${ }^{747}$ defensive, ${ }^{748}$ reactive, ${ }^{749}$ or pro-active ${ }^{750}$ strategy. ${ }^{751}$ The choice of strategy depends on the dossier itself, the lobbyists' room to manoeuvre and certain constraints relating to the lobbyists' agenda, budget or credibility. ${ }^{752}$

In general, individually lobbying firms prefer to be proactive in theory, in that the lobbyists attempt to anticipate the policy outcomes and act accordingly, offering an acceptable (alternative) solution to legislators. It appeared, however, that in reality the firms' strategies are often more reactive or even defensive, depending on the dossier and the business interest at stake. A reactive strategy can perhaps be defined as a more static approach, based primarily on waiting and taking no (initiative) action, ${ }^{753}$ whereas a defensive strategy is more about 'defending an advantage that had already been gained, and/or opposing any evolution in the legislation'. ${ }^{754}$

An example of a more reactive lobbying strategy was given by SuperFit: the firm applied a clearly reactive strategy following the adoption of the regulation on nutrition and

\footnotetext{
747 'A strategy of opposing, blocking and refusing, but without proposing any credible alternatives.' - Gueguen, D., European Lobbying, p. 119.

748 'Defending an advantage that you have gained, and opposing any evolution in the legislation.' Gueguen, D., European Lobbying, p. 120.

749 'Based on waiting, taking no action, and having no strategy.' Gueguen, D., European Lobbying, p. 123.

750 'Ideally [these strategies] are anticipatory (...), dedicated (...), based on the pursuit of an acceptable solution.' Gueguen, D., European Lobbying, p. 123-124.

${ }^{751}$ Ibid., p. 119.

${ }^{752}$ Ibid., p. 117-118.

${ }^{753}$ Ibid., p. 123.

${ }^{754}$ Ibid., p. 120.
} 
health claims made on foods by the Council and Parliament. The manner in which the Regulation ${ }^{755}$ was implemented was not what was expected by the industry, therefore it had to apply a strategy that was clearly responsive to the unanticipated action. As a result, besides the parliamentary questioning of the stringent measures, SuperFit also encouraged a number of MEPs and academics to debate the issue of the rejection of health claims with both the European Commission and EFSA.

An interesting mixture of the aforementioned two lobbying strategies could be detected in relation to the Consumer Rights Directive. A proactive lobbying strategy was initially taken on by the industry. Spearheaded by Seldia (at the time FEDSA), the industry had been advocating the interests of the direct selling sector from the earliest stage possible and was delighted with the original Commission proposal. However, the Commission's intention to cover almost the entire distribution sector proved too ambitious and thus the general provisions were eventually voted out by the European Parliament and the Member States. ${ }^{756}$ Consequently, Seldia and its members had no choice but to change strategy and become defensive - to fiercely oppose amendments in the proposal and the opinion the European Parliament's Committee on Internal Market and Consumer Affairs adopted on the proposed directive, albeit with limited success.

The conclusion is that while the general preference of direct selling corporations is the proactive strategy, the choice depends on a number of factors. Although budgetary constraints do not appear to be a problem for the firms, it is the dossier itself and the room to manoeuvre that are decisive when adopting a strategy. Moreover, as was illustrated with the example of the recently adopted Consumer Rights Directive, the amendments of legislative proposals or changes in the political context can at times necessitate a considerably more defensive course of action.

\subsubsection{The Direct Selling Industry's Access to Political Institutions}

The current section aims to discuss and compare the findings of the empirical research conducted about the direct selling industry lobby with the theory of access discussed in section 7.3.3., while at the same time bearing in mind that the research and surveys conducted are not fully representative.

Overall, it appeared that the labour division between the lobbying actors within the direct selling industry differs from the theoretical model suggested by Bouwen. Empiri-

\footnotetext{
755 The aim of this Regulation is to ensure that any claim made on foods' labelling, presentation or marketing in the European Union is clear, accurate and based on evidence accepted by the whole scientific community.

${ }^{756}$ Seldia Press Release, 'European Parliament slams door in the face of millions of direct sellers', 2 February 2011, http://www.seldia.eu/images/pdf/pr_5_02_02_2011.pdf (last visited 17 September 2014)
} 
cal research has found that national trade associations mainly tend to concentrate on national lobbying, whereas lobbying European institutions appears to fall under the remit of European trade associations. Due to lack of comprehensive statistical data, an exact breakdown of the industry's institutional access is impossible to provide. Nevertheless, based on the assessment of the lobbying dossiers as well as the research conducted on the actors' lobbying dossiers, certain lobbying trends and findings can be detected.

Access to the European Commission -the supranational institution requiring information on aggregated European interests and expert knowledge- appeared substantial. Gaining access to the European Commission, the sole initiator of legislative proposals, is key. As the curve of legislative influence indicates, it is during the proposal phase when the possibility to influence the legislative procedure is at its peak, and therefore anticipation and the ability to contact the Commission -and ideally the draftsperson- is crucial. ${ }^{757}$ The level of influence dramatically decreases with the proposal climbing up the ladder of the Commission's hierarchy. However, new margins of influence open with the first reading in the European Parliament. ${ }^{758}$ As can be seen on the chart below, the margin of influence during the first reading is already smaller than in the initial phase, although it decreases even further and becomes practically non-existent at the Conciliation phase.

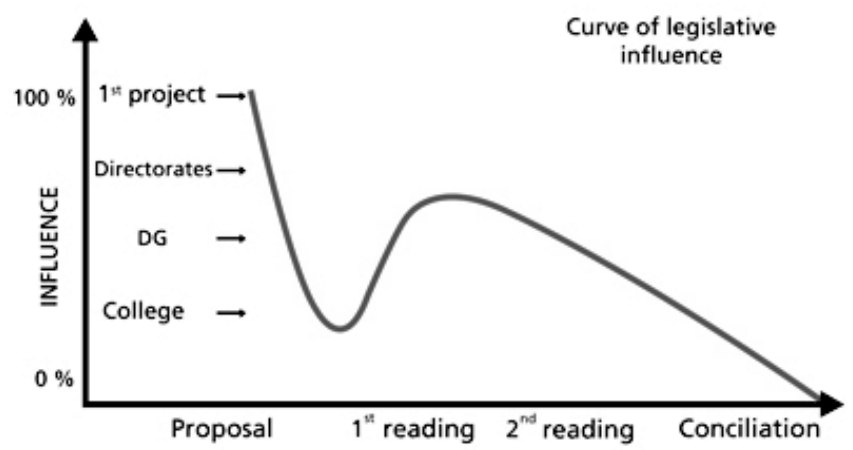

Source: www.unitetheunion.org

From the perspective of substantial legal enquiry into the lobbying dossiers, it was shown how the industry has managed to achieve rather favourable draft proposals at the Commission stage in case of both the Consumer Rights Directive as well as pyramid scheme regulation/MLM deregulation in the Unfair Commercial Practices Directive. While the industry's latter proposal got adopted, it was shown that, in the case of the

${ }^{757}$ Gueguen, D., European lobbying, p. 99.

${ }^{758}$ Ibid., p. 99. 
CRD, the industry failed to convince Member State representatives in the Council and the Parliament to retain the advantageous text as proposed by the European Commission.

Looking at the aspect of lobbying techniques, the interview with Seldia director Maurits Bruggink has confirmed that the trade association -the representative of aggregated European interests- is indeed the most successful in lobbying the Commission. Besides the ability to indicate overarching European interests, a close look at Seldia's/FEDSA's position papers, press releases and other public communication materials throughout the deliberations prior to the adoption of the Consumer Rights Directive and the Unfair Commercial Practices Directive also reflected a high level of technicality in the pre-Commission phase which is also an "access good" that the Commission is open to and welcoming of.

As for the national trade associations, responses to the questionnaire and the publicly available documents have both suggested a low level of direct advocacy activity at the Commission level which, however, is in line with Bouwen's theory concerning the limited access of national associations to this particular institution.

The analysis of legislative lobbying dossiers and the publicly available documentation revealed that only the French, Italian (Avedisco) and UK direct selling federations participated in the public consultation concerning the revision of the Doorstep Selling Directive $^{759}$, although this alone does not exclude the possibility of other, less public, interaction of DSAs with the Commission.

Responses to the questionnaire indicated that DSAs mainly lobbied the Commission to aid the industry's overall European lobby concerning the Consumer Rights Directive (3 out of the 11 respondent DSAs have claimed to lobby the Commission directly in national matters, while 2 have claimed to advocate European industry interests directly at the Commission level).

None of the respondents have claimed to have filed complaints against national measures restricting or banning direct selling with the European Commission. National associations that represent the interests of Member States where there are barriers to direct selling trade unjustifiable by way of reference to the public policy doctrine could in fact file complaints at the European Commission to ensure proper implementation of European law and thereby promote the industry's domestic interests.

\footnotetext{
${ }^{759}$ Based on the Working Document of the Commission: Responses to the consultation on the Council Directive 85/577/EEC of 20 December 1985 to protect the consumer in respect of contracts negotiated away from business premises - Summary of Responses between October 2007 and January 2008, http://ec.europa.eu/consumers/archive/rights/docs/finalsummary30052008.pdf (last visited 17 September 2014)
} 
Individually lobbying corporations' access to the Commission and activity at this level was apparent from the previously analysed lobbying dossiers. Vorwerk's publicly available position paper submitted in the course of deliberations relating to the CRD was introduced in detail and so were the publicly visible lobbying efforts of Amway, the company that co-sponsored the comparative study on pyramid scheme regulations.

Direct selling corporate lobbyists of Sweetscent and SuperFit also claimed they aim to influence legislation at the earliest possible stage and they try to intervene as early as at the preparatory phase. The Commission -usually the responsible desk officers and the unit level- is targeted by the corporations before the general approach is published, but sometimes even thereafter as well, depending on the content of the proposal.

The input provided by the individually lobbying corporations is highly technical, thanks to in-house technical experts (as mentioned by SweetScent) as well as external consultants, think tanks and specialised law-firms.

Similarly, the consultancy lobbying on behalf of Pinkify has claimed that the input provided to the European Commission is usually highly technical.

The European Parliament, the second institution to be scrutinised in terms of institutional access, is mostly in demand of information on aggregated European interests but, given its partially intergovernmental features and the way MEPs are elected, it is also in demand of information on domestic aggregated interests.

Interviews with the two European trade association representatives, Seldia and DSE, revealed relatively little. Seldia claimed to lobby the EP, noting however that the European lobbying group is merely stepping in, performing tasks that should, in theory, be carried out by national lobbying groups. The dossier on entrepreneurship promotion (chapter VI) has described how vocal Seldia and Amway were in the European Parliament, particularly in campaigning for women entrepreneurship. However, since this type of advocacy is more geared towards public relations than to legislative lobbying, it is to be regarded as more of a voice- than an access strategy in its nature.

DSE, the mainly Germanic trade association, has revealed that national affiliation does play a role and is more relevant in the EU Parliament.

National associations are most active in lobbying the European Parliament, as it turned out from the survey. Six out of eleven DSA respondents claimed to have lobbied their national Members of the European Parliament concerning European industry interests, for example in the course of the debate concerning the Consumer Rights Directive, although, seemingly controversially, it was the Parliament's IMCO Committee that ended up introducing certain minimum harmonisation measures to favour some Member States despite the repeated pleas of the direct selling industry. Ten out of eleven DSAs also claimed to address national matters with their national MEPs, although na- 
tional industry interests tend to overlap with European interests, as was the case with the revision of European consumer law.

Individually lobbying firms also appeared to be actively lobbying Members of the European Parliament, given that the level of influence picks up when reaching the parliamentary phase. Interviewees recounted that, in the parliamentary phase, the rapporteurs and shadow rapporteurs of dossiers are approached, and both companies try to provide technical information to the officials. ${ }^{760}$ SweetScent claimed to attempt intervention when amendments are being made to the legislative acts, whereas SuperFit also tries to influence the European Parliament through contacting MEPs, coordinators of political groups, certain particularly active parliament officials and group advisors.

The consultancy representing a direct selling corporation in Brussels mainly approaches Members of the European Parliament for two reasons. MEPs who serve as an important market connection to key markets and/or are active on the respective issue are targeted in the first place.

When it comes to lobbying the Council, the two European lobbying groups claimed to be active, yet, as Seldia director Maurits Bruggink asserted, this institution (just as the EP) should be lobbied by DSAs rather than Seldia. Due to DSAs' lack of resources and expertise in advocacy at high political levels, European trade associations usually step in and attempt to exert influence on the Council, the inter-governmental institution most open to information on domestic interests.

The survey conducted also revealed that a relatively modest number of DSAs lobby the Council. While approximately half of the national associations claimed to have lobbied their national representatives in regards to the Consumer Rights Directive and the ADR Directive, articulating both national- as well as European industry interests, it was also apparent that DSAs' activity and access to the Council is not carried out to its full potential.

The Council of Ministers is generally not the main focus of lobbying for either of the individually lobbying firms. The same applies for lobbying Comitology Groups and Expert Groups of the Council - these institutions are approached predominately by trade associations rather than by the companies themselves. Individually lobbying direct selling corporations' public affairs managers claimed not to lobby the Council, the reason being that on the one hand, it is a rather complicated process to try to inflict influence on this particular institution by companies and, on the other hand, it was asserted that as part of the labour division it is Seldia's task to lobby the Council.

\footnotetext{
${ }^{760}$ This is mainly the stage when expert knowledge is being provided to the European Parliament by the corporations.
} 
The consultancy of Pinkify was the only individually lobbying corporate representative that claimed to lobby the Council through Member States' Permanent Representations. It is the Permanent Representations of the key markets that are approached by the Consultancy on a regular basis; furthermore, in the event that a local matter has escalated to the European level, the respective Permanent Representation is approached by the Consultancy.

To sum up, placing the findings in the framework of the theoretical model of institutional access as established by Pieter Bouwen, based on the assessment of legislative lobbying dossiers and the empirical research conducted, there are certain patterns that can be observed concerning the direct selling industry's advocacy.

Perhaps one of the most important findings is that, while the direct selling industry appears to be active and efficient at the European Commission, its performance weakens significantly at the parliamentary- and the Council phase. Recalling the two legislative dossiers analysed in previous chapters, it is clear that the direct selling lobby did manage to achieve highly favourable legislative initiatives at the Commission, thanks to its European trade association(s) for both the pyramid scheme wording as well as in case of the Consumer Rights Directive. The former wording - as proposed by the Commissionwas adopted by the Parliament and the Council, also because there were no significant opposing interest groups, whereas the Consumer Rights Directive went through major debates and changes after the Commission stage (both the Council and the Parliament have amended the texts) to the detriment of the industry. From a substantial perspective, it was found that the political weight and constitutional nature of the matter was not something the direct selling industry could match up to and that consumer interests are often preferred because they score higher politically than those of the direct selling industry. Results of the empirical enquiry into the industry advocacy suggest shortcomings of the industry lobby when it comes to lobbying Member State representatives, especially in the Council.

Accordingly, assessment of the lobbying dossiers as well as the empirical research suggest that the labour division does not follow Bouwen's model of institutional access whereby each European institution is ideally lobbied by the actors that have the greatest degree of institutional access and supply of access good(s) that the particular institution requires, but is rather divided along the dichotomy of European issues and national issues. In concreto, while the two European trade associations are expected to lobby all European institutions, national direct selling associations focus more on national issues and much less on European lobbying. This advocacy structure may very well be the residue of the pre-Lisbon era, when the Parliament and the Council had a much smaller 
role in the legislative procedure and the direct advocacy of national players was not as important as after Lisbon.

It is precisely this set-up that renders the industry advocacy to be significantly less efficient than it could be - while the European trade associations are expected by other direct selling lobbying actors to lobby all three EU institutions effectively, the new institutional reality and legislative procedure calls for a considerably advanced approach and, in particular, the greater involvement of national federations.

The current state of play is that while the industry lobby appears very successful at the Commission level, the degree of access to the Council appears to be the lowest due to the fact that the two types of actors - national federations and individual corporations- that would have the capability to access this particular institution through their ability to provide information on domestic interests appear to be underperforming in this respect and leave the task to European trade associations that have very limited access to this particular institution. While only approximately half of the voluntary respondents of the survey concerning the activity of national direct selling associations claimed to lobby the Council, representatives of the two individually lobbying corporations claimed not to lobby the Council at all.

National federations thus seem to hold considerable untapped potential for the direct selling industry advocacy. Due to the fact that national interests still prevail in the Council and are important in the EP as well, information is in demand in these institutions about the aggregated national interests. Furthermore, as the Council shares increasing legislative power (together with the European Parliament) and can influence the final shape of the legislative proposal -when it has already reached a very high level of technicality and further expert knowledge may not be needed-information that can facilitate the bargaining process among Member States can be highly useful for the Council. ${ }^{761}$

Furthermore, a virtual right of veto has been granted to national parliaments by Protocol No. $1^{762}$ and Protocol No. $2^{763}$ of the Lisbon Treaty that could also potentially be a tool in the hands of national lobbyists. Established to underscore the principle of subsidiarity, the "yellow card system" allows one third ${ }^{764}$ or more of national Parliaments to block draft legislative proposals of the European Commission. Under this system, where reasoned opinions on a draft legislative act's non-compliance with the principle of sub-

\footnotetext{
${ }^{761}$ Bouwen P., A Comparative Study of Business Lobbying in the European Parliament, the European Commission and the Council of Ministers , MPIfG Discussion Paper 02/7, ISSN 0944-2073, November 2002, p.1516.

${ }^{762}$ TFEU Protocol (No. 1) on the Role of National Parliaments in the European Union

${ }^{763}$ TFEU Protocol (No. 2) on the Application of the Principles of Subsidiarity and Proportionality

${ }^{764}$ In the pillar of Justice- and Home Affairs, the threshold is one quarter.
} 
sidiarity represent 'at least one third of all votes allocated to the national Parliaments [...] the draft must be reviewed. [...] After such review, the Commission [...] may decide to maintain, amend or withdraw the draft. Reasons must be given for this decision.' ${ }^{765}$ Article 7(3) of Protocol No. 2 also defines an "orange card" system which stipulates that if 'a majority of $55 \%$ of the members of the Council ... is of the opinion that the proposal is not compatible with the principle of subsidiarity, the legislative proposal shall not be given further consideration.'

On the other hand, although it is not entirely the main focus of the present study, problems relating to national lobbying were also included in the research, given the relevance of the question from the perspective of labour division. European trade associations and a direct selling corporation have namely indicated that there has recently been an increasing need for European lobby groups to get involved in national advocacy due to the lack of resources and professional lobbyists at some DSAs. While Seldia and DSE may have the expertise in advocacy techniques, it is doubtful whether they can efficiently lobby national governments without having a network of senior government officials or in-depth knowledge of local political affairs and understanding of the legal system and local language.

\subsubsection{Litigation Strategies}

A complementary means to political strategies to influence public policy and to shape regulation is litigation, a method of influence as yet unexplored by the direct selling advocacy. Unlike traditional lobbying, where the successful output requires the persuasion of the majority of the legislature, litigation may be an appealing option for minority interests to challenge rules. The Court of Justice of the European Union is the EU venue that has institutionalised profound changes in European law and has therefore become a target for interest groups seeking policy changes. ${ }^{766}$

Indeed, institutionalised as precedents, rulings of the CJEU have served as basis of changes of EU law, including the "constitutionalisation" of the Treaties, ${ }^{767}$ trade liberali-

\footnotetext{
${ }^{765}$ Article 7(2) Protocol No. 2 of the Lisbon Treaty

${ }^{766}$ McCown, M., 'Interest Groups and the European Court of Justice', in: Coen, D. and Richardson, J. (eds.) Lobbying the European Union: Institutions, Actors, and Issues, chapter 5, (Oxford University Press, Oxford, 2009)

${ }^{767}$ Weiler, J., H., The Constitution of Europe: "Do the new clothes have an emperor?" and Other Essays on European Integration (Cambridge University Press, Cambridge, 1999) as cited by Bouwen and McCowm, 'Lobbying versus Litigation: Political and Legal Strategies of Interest Representation in the European Union, Empirical Studies of Interest Representation in the European Union', Special Issue of the Journal of European Public Policy, Working Paper 22, School of Public Policy, University College London, 20 January 2006, p. 8.
} 
sation, ${ }^{768}$ evolution of the separation of powers rules ${ }^{769}$ and the creation of new policy areas. $^{770}$

Precisely because the direct selling interest group tends to represent a minority interest, it could potentially supplement its current interest representation techniques with strategic litigation in the field of direct selling trade barriers, for example, so as to annul national protectionist measures that impose non-tariff barriers to trade. Attacking these restrictive Member State regulations in front of the Court of Justice -as a last resort, should the efforts made towards the proper implementation of the Consumer Rights Directive fail- would allow the CJEU to take a step towards the establishment of the common market through negative integration.

In addition to interpreting EU law to ensure it is applied in the same way in all EU Member States, or the settlement of legal disputes between EU governments and EU institutions, the Court of Justice also deals with cases brought by individuals, companies or organisations. It was the declaration in Van Gend en Loos (ECJ 26/62) that EU law applies to individuals as well as to Member States that opened the door to private interest litigation. ${ }^{771}$

The incentive of private actors to litigate depends on both the institutional environment as well as the available resources and organisational form of private interests.

The institutional environment in which choosing to go to court is a viable option occurs when actors are faced with a relatively high number of oppositional Member States, i.e. in the event that an organisational actor (e.g. a Member State government or a part thereof) is very opposed to an EU rule or there is a lack of consensus among Member States to change a particular measure. Secondly, in times of legislative deadlock, litiga-

\footnotetext{
${ }^{768}$ Stone Sweet, A. and Brunell, T., 'Constructing a Supranational Constitution: Dispute Resolution and Governance in the European Community', 92 American Political Science Review (1999), p. 63-81, 1999 and

Stone Sweet, A. and McCown, M., 'Free Movement of Goods in the European Union', In Alec Stone Sweet, ed.: The Judicial Construction of Europe (Oxford University Press, Oxford, 2004) as cited by Bouwen and McCowm, 'Lobbying versus Litigation: Political and Legal Strategies of Interest Representation in the European Union, Empirical Studies of Interest Representation in the European Union', Special Issue of the Journal of European Public Policy, Working Paper 22, School of Public Policy, University College London, 20 January 2006, p.8.

${ }^{769}$ McCown, M., 'The European Parliament Before the Bench: ECJ Precedent and EP Litigation Strategies' 10 Journal of European Public Policy (2003) p. 974-995 as cited by Bouwen and McCowm, 'Lobbying versus Litigation: Political and Legal Strategies of Interest Representation in the European Union, Empirical Studies of Interest Representation in the European Union', Special Issue of the Journal of European Public Policy, Working Paper 22, School of Public Policy, University College London, 20 January 2006, p. 8.

${ }^{770}$ Bouwen, P. and McCown, M., 'Lobbying versus Litigation: Political and Legal Strategies of Interest Representation in the European Union, Empirical Studies of Interest Representation in the European Union', Special Issue of the Journal of European Public Policy, Working Paper 22, School of Public Policy, University College London, 20 January 2006, p. 8.

${ }^{771}$ Ibid., p. 9.
} 
tion may be an effective means of shaping public policy. ${ }^{772}$ The rise of far-right political movements and parties throughout Europe, and thus potentially in the European Parliament, may increase the legislative deadlock which could entail consequences for advocacy groups' influence and choice of interest representation strategies.

Besides the environment in which interest groups operate, characteristics intrinsic to interest groups shape their recourse to litigation strategies, similar to their choice of access strategies. ${ }^{773}$

As for the organisational structure, Alter and Vargas found that the broader or more encompassing the interest group's mandate or constituency is, the less likely it will choose a litigation strategy. ${ }^{774}$ The bigger the interest group's constituency, the harder it is for them to reach a consensus among the members, and the more likely that one of the members' interests will be violated by a general ruling. It follows from this line of reasoning that individual corporations and national associations are expected to litigate more than European trade associations.

Research concerning actors of the direct selling industry's advocacy revealed that none of the actors were engaged in strategic litigation. Possible litigants, individual companies and national associations have demonstrated a low level of litigation incentive. Large companies that may have the resources necessary to litigate, such as Amway or Herbalife, may have a more defensive approach given the multiple lawsuits that have been brought against them in the past and therefore are less inclined to go to court on their own initiative.

National associations appeared to be less active at European level in general, but especially when it comes to litigation. In the course of the empirical research none of the direct selling national associations claimed to have encouraged their respective national governments to intervene in cases before the CJEU, even though the Court has in fact dealt with legal problems of crucial importance for the industry, such as the very recent request for a preliminary ruling on the interpretation of the UCPD's pyramid clause in the 4 finance case (C-515/12).

Interest groups are more restricted concerning intervention in cases before the CJEU. Unlike in the United States, the submission of amicus curiae briefs (information or advice in respect to some matter of law that directly affects the case in question offered by a third party [such as a professional person or organisation] that is not party to

\footnotetext{
${ }^{772}$ Ibid., p. 10.

${ }^{773}$ Ibid., p. 10.

${ }^{774}$ Alter, K. and Vargas, J., 'Explaining Variation in the Use of European Litigation Strategies', 33 Comparative Political Studies, Number 4 (2000), p. 452-482., p. 473.
} 
a particular litigation) is not permitted under EU law. ${ }^{775}$ According to the Statute of the Court of Justice of the European Union, only 'Member States and institutions of the Union may intervene in cases before the Court of Justice' ${ }^{776}$ leaving trade associations room to intervene through national and European institutions - typically, for national associations through their national governments and for European trade associations through the European Commission.

On the other hand, non-tariff barriers to direct selling trade could best be attacked by private actors at national level (if all else fails), by bringing the case before the Court of Justice through a request for a preliminary ruling. National direct selling associations hold the potential to refine their interest representational activities through both lobbying for Member State intervention in Court cases of high relevance and/or through recourse to litigation against restrictive national measures.

The literature suggests that the successful pursuit of litigation strategies -particularly that of repeat litigation - is resource intensive and requires a concentrated and sophisticated strategy. Rapid repeat litigation is essentially a strategy where litigants, once they have won a case, rapidly bring a subsequent suit before the court to reinforce the earlier, favourable ruling by having it applied as a precedent in later decisions. Private actors have found repeat litigation to be particularly effective in EU judicial politics. ${ }^{777}$

For a long time, the classic venue to attack protectionist national measures- and particularly in the era of the Luxembourg Compromise - was the Court of Justice. It was namely in this period of legislative deadlock, when the legislative output was extremely limited, that the CJEU delivered its Dassonville and Cassis decisions, substantially weakening Member States' powers to impose restrictions to trade and discriminating against imports. ${ }^{778}$

\footnotetext{
${ }^{775}$ McCown, M., 'Interest Groups and the European Court of Justice', in: Coen, D. and Richardson, J. (eds.) Lobbying the European Union: Institutions, Actors, and Issues, p. 89-104 (Nova Science Publishers, New York, NY, 2009), p. 90-93.

${ }^{776}$ Article 40 on Protocol No. 3 of the Lisbon Treaty on the Statutes of the Court of Justice of the European Union

${ }^{777}$ McCown, M., 'Rewriting the Treaties with Precedent: Intellectual Property Rights and EU Law'. Paper read at the European Union Studies Association Annual Conference. Nashville, TN. April 2003, as cited by Bouwen, P., and McCown, M., 'Lobbying versus litigation: political and legal strategies of interest representation in the European Union', 14 Journal of European Public Policy, Number 3 (2007), p. 422-443, p. 427.

${ }^{778}$ Bouwen, P. and McCown, M., 'Lobbying versus Litigation: Political and Legal Strategies of Interest Representation in the European Union, Empirical Studies of Interest Representation in the European Union', Special Issue of the Journal of European Public Policy, Working Paper 22, School of Public Policy, University College London, 20 January 2006, p. 24.
} 


\subsection{Conclusion}

The aim of the present chapter was to enquire into the direct selling industry advocacy from a political sciences perspective.

In an effort to map the industry's lobbying techniques, overarching empirical research was conducted with the involvement of both European trade associations, 11 direct selling trade associations and 5 direct selling corporations' representatives. Due to the highly sensitive and confidential nature of the subject matter, participation in the empirical research was voluntary and thus, the resulting samples were accidental. Results of the empirical research are therefore not representative of the entire population. However, the trends observed in the course of the empirical research have shown considerable overlaps with the conclusions drawn from the legal analysis of the lobbying dossiers, thereby increasing the validity and credibility of the empirical research results.

Findings of the research were interpreted within the framework of the public choice theory whereby the direct selling industry advocacy was deemed to be an economically rational group attempting to maximise the common interest of its members. Based on the three-dimensional theory of Lukes on power, ${ }^{779}$ it was discovered that direct selling lobbyists will attempt to influence all aspects of political power: ${ }^{780}$ political decision making, the political agenda and the shaping of policymakers' and the publics' perceptions.

Looking at the first dimension of power, political decision-making, the direct selling industry was analysed within the framework of the Beckerian model of competing interest groups. It was shown how the free competition of interest groups amounted to a zero-sum political game whereby the performance of a lobby group is relative to that of others and is primarily aimed at utility maximisation. The theory was exemplified by the Consumer Rights Directive- and MLM deregulation-related lobby of the direct selling industry and it was shown how competing interests (or the lack thereof) contributed to the legislative output in each case.

While agenda setting appeared to be a successful venture when opposing the revision of the Unfair Commercial Practices Directive, and in particular Item 14 of Annex I, the third dimension of power, influence of the political culture, was found to be targeted through self-regulation and the promotion of entrepreneurship.

Subsequently, the direct selling industry advocacy was observed in light of Mancur Olson's theoretical principles of interest representation. The Olsonian paradox, that a

\footnotetext{
${ }^{779}$ Lukes, S., Power: A Radical View (Macmillan Publishing, Basingstoke, 1974)

${ }^{780}$ See Svendsen, G. T., 'Evaluating and Regulating the Impacts of Lobbying in the EU? The Case Study of Green Industries', 21 Environmental Policy and Governance, Issue 2 (2011), p. 131-142.
} 
small group representing concentrated interests has a greater capability to carry out successful lobbying than a larger group with dispersed interests, appeared to explain the industry's success in influencing European unfair competition law in particular, thereby challenging the classic pluralistic assumption that interest groups have an equal chance to participate in the political pressure system, and thus also questioning whether the free competition of interest groups prevents undue influence of certain advocacy groups.

Geared towards the advancement of the industry's common interests, collective action of direct selling corporations succeeds through participation in trade associations and ad hoc industry platforms, while individual action is taken in the event that the company represents an individual interest (when the importance of the lobbying issue is such that it calls for reinforcement, or in relation to significant domestic issues which require that the matter be escalated to European level).

In terms of the industry split, lobbying dossiers' analysis has shown that the strategic interests of the Seldia and DSE groups are largely identical, whereas interviews with trade association representatives have revealed that the industry split occurred because of FEDSA members' unequal selective incentives to engage in collective action. The result is a long-standing prisoner's dilemma-type situation of the two European trade associations which, however, at the advocacy level appears to be resolved (and sustained) by way of the two players' cooperation in advocacy in the strictest sense. Nevertheless, cooperation does not necessarily extend to all fields of operation.

The last dimension of the present enquiry related to the theoretical foundations of Pieter Bouwen's access theory, which has offered insight into the institutional access of the direct selling industry lobby. Empirical research has discovered that the industry advocacy tends to have the largest influence on the European Commission, mainly thanks to the lobbying efforts of the European trade associations and individually lobbying corporations that are in the best position to provide this supranational institution with information on the aggregated European interests of the industry. Access to the European Parliament and especially the Council appeared to be considerably smaller, due to the fact that the present labour division within the direct selling industry advocacy renders it incapable of fulfilling its full potential.

Finally, strategic litigation is not a course of action that is pursued by the direct selling industry. Although this strategy could be used in the promotion of minority interests and as such has proven to be an important tool for achieving trade liberalisation, the industry appeared not to utilise this mode of interest representation at all. 
Summary of Findings 



\subsection{Introduction}

The overall aim of the present study was to map the direct selling industry's advocacy in the European Union and to thereby increase lobbying transparency and the openness of the European decision-making process. Aiming to provide a comprehensive understanding of the industry advocacy, the research was based on a legal and an empirical enquiry into the direct selling sector's advocacy in an effort to examine the subject from both a substantive as well as a technical perspective.

While general theoretical literature on the subject of private interest representation in the European Union is constantly expanding, the systematic examination of the direct selling industry's advocacy in the Brussels political arena is a novel contribution to existing theories. The legal enquiry into this particular business lobby group's targeted actions, the comparative analysis of the strategic aims of the sector and the eventual legislative output entails novel revelations concerning the shaping of European consumerand commercial law through a private interest group, whereas the individual assessment of the actors' lobbying techniques and the aggregation thereof has provided an opportunity to reflect upon private interest representation as a system of coordinated action striving to influence the European institutions and the European legislative procedure.

The study has sought to answer the following research questions:

1. Which legal instruments currently exist in the EU that regulate key aspects of the direct selling industry and serve as a basis for the present legal enquiry into the industry lobby?

2. What are the strategic legislative lobbying goals of the direct selling industry's interest representation in Brussels?

3. To what extent did the industry advocacy manage to influence European law and shape it according to its needs?

4. What are the non-legislative strategic lobbying goals of the direct selling industry's interest representation in Brussels?

5. What are the main organisational forms of direct selling interest representation?

6. Does the direct selling advocacy comply with the theses of the public choice theory?

7. What is the reason why a small and sectorial interest group such as the direct selling industry advocacy could have had a relatively considerable impact on certain aspects of European private law overall? 
8. Is the performance of the industry lobby even and equally strong throughout the legislative procedure?

9. In what ways does the fourth, non-legislative dossier influence political decision-making?

10. What type of advocacy strategies does each lobbying actor adopt?

11. How do various actors' lobbying techniques interrelate and to what extent are they complementary?

The structure of this last chapter summarising the study's findings is designed as follows. The following section (8.2.) will make some preliminary remarks such as background information necessary to understand the idiosyncrasies of the direct selling industry, and will subsequently present the answer to the first, preliminary research question as regards the Directives that served as the basis for the legal enquiry into the direct selling industry lobby. Thereafter, section 8.3. on the industry's strategic interests sets out to provide answers to the research questions concerning the strategic interests of the sector, assessing the extent to which the industry was efficient in realising the set goals and, lastly, evaluating the legislative output (Research questions (2), (3), (4) and (5)). The last part (section 8.4.) will look into the more technical aspects of direct selling advocacy through the examination of the main organisational forms of interest representation (Question (6)), the type of advocacy strategies actors tends to adopt (Question (7)) and the interrelation of the industry lobby's actors and their behaviour (Question (8)).

\subsection{Preliminary Remarks and the Legal Background}

Defined as one of the three main distribution channels alongside in-store retail and distance selling, direct selling was conceptualised as the obtainment of orders and the supply of consumer products (goods and services) to private individuals away from normal retail premises, usually in their homes or places of work, in transactions initiated and/or concluded by a salesperson. ${ }^{781}$

With an estimated production of EUR18.768 million (excl. VAT) in 2013 in retail sales attained by over 5.18 million direct sellers in the EU, the direct selling distribution

\footnotetext{
${ }^{781}$ The definition was conceptualised by Richard Berry in 1997 and was later adapted by Brodie et al. in 2004 in Public Perceptions of Direct Selling: An International Perspective, Westminster Business School Research Report 2004 (Westminster University Press, Westminster, 2004), p. 3.
} 
method offers significant advantages to consumers and entrepreneurs alike. ${ }^{782}$ Consumers who are underserved by other retail channels (home-bound seniors or inhabitants of rural areas) are facilitated access to goods that they would otherwise not be able to acquire. Furthermore, the flexible work schedule, low entry barriers and a simplified business model combined with skills training offers others an alternative to employment, and/or the possibility of (re-)integrating into the job market, which may be particularly beneficial for under-represented demographic groups in business life such as seniors, migrants, women or even those with a low level of education.

On the other hand, direct selling is subject to frequent criticisms due to a high number of consumer- and direct seller grievances that disturb the advantages of the direct selling channel. In terms of consumer complaints, the application of pressure sales techniques, the invasion of consumers' privacy and overpriced products appear to be the greatest problems, while (potential) distributors at times have to face issues concerning unethical recruitment techniques or the exploitation of social networks, not to mention the insecurity of earnings and the high level of rejection direct sellers have to face.

Notwithstanding the aforementioned problems inherent to the sales method, the greatest problem by far is related to pyramid schemes. Pyramid promotional schemes frequently disguise themselves as legitimate multi-level marketing companies, namely offering a mere token product to conceal the money transfer schemes that defraud participants and cause multi-million dollar damages. The scams have cast an overly negative light on network marketers especially, but also on the entire direct selling industry by associating it with fraudulent practices and marketplace abuses.

The idiosyncrasies of the industry and abuses of the sales channel form the basis of legislation governing the area of off-premises transactions, which in turn establish the foundations of the industry lobby. Accordingly, in response to the first, preliminary, research question regarding the European legal instruments that underlie the enquiry into the direct selling industry's Brussels advocacy, four directives have been described briefly in an effort to help understand the case-studies to follow.

In the area of consumer contract law, a measure of minimum harmonisation, Directive 85/577/EEC ("Doorstep Selling Directive"), and a maximum harmonisation instrument, Directive 2011/83/EU ("Consumer Rights Directive") have been introduced, with special emphasis laid on the two main features of protection granted to consumers: the provision of pre-contractual information and the mandatory right of withdrawal.

782 Seldia website, “Statistics 2013”, http://www.seldia.eu/images/pdf/2013_stat_general_presentation 31072014.pdf (last visited 17 September 2014) 
Particularly important in terms of the assessment of European consumer law was the paradigmatic transition from minimum to maximum harmonisation with a view to create a coherent system of consumer acquis and to establish a level playing field for consumers and traders alike. Along with the fact that national laws may no longer exceed the terms of Directive 2011/83/EU, the most important conclusions of the shift in the European regulatory approach were the harmonisation of the essential contractual elements of off-premises transactions on the one hand and, on the other hand, the fact that Member States no longer have the freedom to maintain or introduce a total or partial prohibition on the conclusion of contracts away from business premises, inasmuch as they consider this to be in the interest of consumers (expect for the already existing payment bans).

European unfair competition law in both business-to-consumer and business-tobusiness dimensions has been described through Directives 2005/29/EC ("Unfair Commercial Practices Directive", UCPD) and 2006/114/EC ("Misleading and Comparative Advertising Directive", MCAD) respectively. Highlighted were, besides the general rules of fair trading, the main issues of concern in terms of unfair commercial practices in off-premises transactions. Namely, the prohibition of aggressive practices to pressure consumers to purchase products, the disallowance of unfair commercial practices covering unfair sales techniques, misleading and exaggerated earnings claims to lure recruits into the business and the ban of pyramid promotional schemes. Rules on industry selfregulation and codes of conduct, in the framework of Directives 2005/29/EC, have been elaborated.

The study did not assess Directive 93/13/EEC on unfair terms in consumer contracts, which is a highly important measure governing off-premises consumer contracts but is not necessarily the target of direct selling industry lobbying and Directive $86 / 653 /$ EEC on the coordination of the laws of the Member States relating to selfemployed commercial agents, concerning which the direct selling industry could not come up with a comprehensive lobbying dossier at European level (yet).

\subsection{Strategic Industry Interests and Industry Advocacy}

The strategic interests and lobbying goals of the direct selling industry advocacy have been identified through the exploratory analysis of four lobbying dossiers comprising case studies concerning Directive 2011/83/EU on consumer rights, the pyramid promotional scheme definition as enshrined in Item 14, Annex I of Directive 2005/29/EC, industry self-regulation and, lastly, entrepreneurship promotion. 
The method applied to the substantial enquiry into the industry advocacy was that of legal-doctrinal analysis. Following the identification of legal problems and relevant matters for the direct selling industry, the allocated issues were analysed in detail primarily from the perspective of this particular interest group (and its various actors), focusing on the legislative outcome the industry lobby strived to achieve, by studying the publicly available documents and position papers submitted to the EU institutions. The efficiency of the industry lobby and the quality of the legislative output was examined through the comparison of the industry's proposals and the adopted norms.

The structural complexity of the legal research was exacerbated by the fact that the European direct selling industry's lobby group had split in 2006, wherefore positions of multiple actors had to be held under scrutiny. The original European trade association, the Federation of Direct Selling Associations, FEDSA, was founded in 1968 and, after almost half a century of activity was abandoned by a number of member companies and direct selling associations in order to found another trade association, Direct Selling Europe (DSE) in 2007. As a result of the rift, the original association has undergone major organisational restructuring and was renamed Seldia.

Seldia today has 28 national Direct Selling Associations (23 of which represents EU Member States) and 15 corporate members (including the direct selling giants, Amway, Herbalife, Mary Kay or Oriflame) whereas the competing trade association, Direct Selling Europe, has 5 national Direct Selling Associations (4 of which represent EU Member States) and 11 corporate members (such as Tupperware, AVON and Vorwerk).

General conclusions and lessons emerging from the detailed enquiry appeared to be concentrated around two interdependent, elementary findings. Number one, the industry's constant battle against its own morality deficit and, number two, its general preference for a fully harmonised body of law.

The industry has been suffering from a morality deficit since the emergence of fraudulent schemes and new network marketing techniques within this channel of retail. The issue at hand is concentrated around the fact that, with the evolution of direct selling and multi-level marketing techniques, new and sophisticated scams have also evolved. Throughout the study it was restated over and over how fraudulent pyramid schemes tend to disguise themselves as legitimate MLM companies, wherefore it is very important to have a very clear, strict and tight set of rules that lays down the criteria by which pyramids can be separated from legitimate MLMs. The ambiguity of rules governing multi-level marketing and pyramid schemes increases the grey area that separates scams and MLMs, creates legal uncertainty for legitimate traders and allows scams to proliferate, thereby increasing the risk of government intervention and regulatory action. In an uncertain regulatory environment that surrounds network marketers, it is 
very difficult to tell a legitimate MLM from a fraudulent pyramid scheme, wherefore the public trust in multi-level marketing companies tends to be low. A further result of this situation is an internal conflict within the industry: while MLMs are striving to be accepted as serious businesses, direct selling companies that apply other types of marketing techniques -such as single-level marketing or party plans- may not want to be associated with MLMs and may want to distance themselves from network marketing.

Naturally, this issue determines the entire industry, including its advocacy. The present study has assessed the way the industry has built up three lobbying strategies to counterbalance the resulting morality deficit. The first course of action has been to shape statutory law, i.e. to influence the European pyramid scheme definition, the second strategy to moralise the industry and to fend off government intervention through the engagement in private regulation and, the third strategy has been devoted to the promotion of the industry's social values in order to improve the industry's image.

The second key determinant, the industry's general preference for the convergence of laws, has been observed through the assessment of the dossier on the Consumer Rights Directive and the adoption of the sector-specific standardised system of private norms.

Research has found that the industry's support of the establishment of the internal market without internal frontiers in which the free movement of goods and services are ensured is motivated by the lower costs of compliance and the greater degree of legal certainty that stem from a unified regime. This is because direct selling corporations tend to be multinational companies that operate in all or in a significant number of Member States and are therefore interested in the establishment of a simplified and coherent regime. Lastly, trade liberalisation within the EU and the abolishment of barriers to the free movement of goods, such as bans or restrictions on the direct selling sales channel (e.g. the ban on doorstep selling in Denmark or the ban on the collection of payments during the withdrawal period in France and Belgium), or the ban on sales of non-hazardous products through direct selling (e.g. the ban on sales of jewellery and cosmetics through direct selling in Austria, the ban on sales of food supplements through direct selling in Hungary), is a paramount issue for the industry as it is deemed an undue interference in the competitive conditions of the direct selling industry.

The establishment of a uniform system of private standards does not contradict the industry's preference for full harmonisation, as one may think at first glance, but rather underlines its need to operate in a harmonised regime. The industry's Codes of Ethics in its entirety, covering conduct towards consumers as well as towards distributors and other direct selling companies, was adopted in Europe as early as 1995, a decade before the adoption of the first full harmonisation measure in the consumer protection area, 
the Unfair Commercial Practices Directive. Conversely, the status of direct sellers or independent commercial agents has not been harmonised by European law to this day.

Examination of the specific strategic interests of the direct selling industry lobby, as well as the industry's efficiency in the realisation of said strategic interests and, finally, evaluation of the resulting norms was achieved through the analysis of the individual dossiers.

Dossier 1 on the industry lobby concerning the Consumer Rights Directive has set out to examine the industry advocacy actors' position in the decade-long path leading up to the adoption of the Directive and to then to reflect on the efficiency and contributions of the industry lobby in light of the adopted legal act.

The broader political context of the Directive's preparation and adoption was demonstrated through the description of the Commission's ambitious intent to revise, systematise and codify the European consumer acquis by making a paradigmatic shift from minimum to maximum harmonisation. The shift in the regulatory approach has raised issues of a constitutional nature and provoked Member States' resistance concerning the implied relocation of regulatory power. Member States' and consumers' heavy opposition eventually led to a political compromise whereby the maximum harmonisation nature of the Directive remained, but major concessions had to be made by the Commission in return. Not only was the scope of Consumer Rights Directive trimmed down from eight directives to two, but there were further compromises made through the insertion of minimum harmonisation clauses.

Against this background, the direct selling industry underlined the need for a stateof-the-art law complying with $21^{\text {st }}$ century needs, bringing direct selling in line with the objectives of the Lisbon agenda, implementing the policy objective of creating a European retail market and a level playing field between the various sectors of B2C retail trade in the Community. The plea to bring Directive 85/577 up-to-date with the economic reality thus meant the full harmonisation of the respective body of law at an "acceptable level" of consumer protection (for the industry), and was a goal supported by both major lobbying groups within the sector.

Modernisation at the political level, i.e. the industry's quest for maximum harmonisation, was in line with the Commission's intentions to decrease legal fragmentation and to create a coherent system of European private -or at least consumer- law to reduce business costs. The eventual outcome, the maximum harmonisation nature of the Directive, despite the derogations, is a clear benefit for the direct selling sector, although it was not so much the achievement of the industry lobby, but rather the result of an overarching political compromise. 
An important implication of maximum harmonisation for the industry is expected to be the abrogation of direct selling trade barriers that are currently amongst the most pertinent problems of direct selling in the EU. Assessment of the CJEU's so-called "Buet-line of case law" examining the direct selling trade barriers' compatibility with the free movement of goods principle, prior to the adoption of the Consumer Rights Directive, revealed that direct selling trade barriers were areas which appeared to have been reserved for national regulators where the CJEU was reluctant to interfere, even if these national laws had the potential to hinder intra-Community trade. Although the industry could not achieve a wording that expressly prohibits Member States from adopting restrictive national measures, national provisions that are more protective than the level prescribed by the CRD to safeguard consumers -aside from the already existing payment bans- are expected to be cleansed from Member States' legal regimes thereby giving way to full harmonisation of $\mathrm{B} 2 \mathrm{C}$ transactions concluded off premises. ${ }^{783}$

By and large, full harmonisation of consumer contract law for the direct selling sector is clearly a positive development for the industry, while the introduction of certain minimum harmonisation clauses has been considered the greatest defeat of the industry advocacy. While there is no evidence to justify the maintenance of payment bans (Art.9(3)) from a consumer perspective, which on the other hand is an unreasonable interference in the competitive conditions of the direct selling business, ${ }^{784}$ and it is doubtful whether consumers will benefit from Member States' entitlement to prescribe additional information requirements (Article 6(8)) to the already extensive disclosure obligations, the permission granted by Recital 13 to extend the scope of the Directive to SMEs and the minimum harmonisation of the exemption of low value transactions (Art.3(4)) may be seen as positive developments for stakeholders other than the direct selling industry. From this perspective, it can be argued that the minimum harmonisation provisions loosen the rigidity of the fully harmonised framework, allowing various jurisdictions to come up with divergent solutions and preferences in terms of the level of consumer protection, at least in some areas.

While the added value of full harmonisation has been subject to intense debate, even those highly critical of maximum harmonisation agree that the length and the exercise of the withdrawal period becoming uniform is a positive development from the perspective of European consumer law. In this respect, the industry lobby, and particularly FEDSA have made highly constructive contributions to European law through the pro-

\footnotetext{
${ }^{783}$ Weatherill, S., 49 Common Market Law Review, p. 1279-1318. (2012), , p. 1311.

${ }^{784}$ Response of the Direct Selling Association (of the UK) to the Discussion Paper on the Review of Directive 85/577/EEC of 9 October 2007, p.10., http://ec.europa.eu/consumers/rights/docs/ds_resp_ukdsa.pdf, (last visited 17 September 2014)
} 
posal of a standard withdrawal form or the delimitation of the withdrawal period in case of trader default. Although the latter suggestion does not increase the level of consumer protection (unlike the former), it does increase legal certainty and as such is a positive development.

A failure for the industry (both FEDSA and DSE), on the other hand, was the fact that solicited transactions and repeat sales based on catalogues have been brought under the scope of the Directive, as well as the fact that the length of the withdrawal period was set at 14 days (FEDSA had proposed 7 days) commencing on the day of delivery, instead of the day of the signature of the withdrawal form. These measures are again clearly reflective of the consumer movements' success in the battle against the industry in the revision of the acquis.

Looking at the overall lobbying strategy, it was found that the industry was very proactive in the pre-Commission phase as a result of which the initial Commission proposal was highly advantageous for the direct selling sector. It was in the postCommission phase when things took a turn for the worse for the direct selling industry and political battles called for a considerably more defensive strategy. In this respect, it was examined whether this specific case complied with the general trend, as observed by Levitt, ${ }^{785}$ of the industry lobby being more successful in the highly technical preCommission phase and subsequently declining in the political post-Commission phase due to the industry's refusal to politicise its messaging. Assessment of the direct selling industry's position papers, press releases and communication has revealed that the direct selling industry lobby did not make the classic mistake Levitt referred to in the course of its advocacy concerning the Consumer Rights Directive. Pre-Commission submissions were all highly technical, complete with complex legal argumentation, whereas the lobbying documents in the post-Commission phase were considerably simplified and at times even attempted to strike a chord with MEPs.

Rather, the questionable outcome was the result of a complexity of reasons. Firstly, the paradigmatic shift from minimum to maximum harmonisation provoked a political battle between the Commission and the Member States that went way beyond the significance of a technical legislative revision, raising issues of a constitutional nature upon which the direct selling industry had no, or only very little, influence.

Secondly, since the European legislator takes a variety of interests into consideration, the direct selling industry also had to compete with consumer organisations, the interests of which often tend to score higher politically than those of the slightly controversial direct selling industry.

${ }^{785}$ Interview with Mr. Simon Levitt on 22 October 2013 in Brussels. 
Thirdly, it was found that the lack of discipline within the sector and the fact that certain actors were lobbying against each other on some issues such as the exemption of repeat transactions was detrimental for the industry.

Lastly, the low level of national direct selling associations' participation in the industry's lobbying efforts was striking, as direct lobbying efforts were found only in three national federations' public records. The dossier thus served as evidence for the revelation that DSAs in general tend to be less active in Brussels and especially in their interaction with the Council, where these associations could, in theory, have the highest degree of influence.

All in all, the direct selling industry advocacy was found to have achieved only very modest success in terms of the revision of the consumer acquis. The industry appeared to have a limited ability to exert influence on Member States, whereby the structure and labour division between the European trade association(s) and the national federations may need to be re-thought in order to increase the efficiency of the industry advocacy in the Brussels political arena.

The second field of enquiry regarding the industry's strategic interests concerned the European pyramid scheme regulation. The distinction in unfair competition law between legitimate direct selling companies and pyramid schemes tends to be somewhat of a grey area and, as such, is a critical field for the direct selling industry. Dossier 2 on the European pyramid scheme regulation was thus devoted to the assessment of the industry's interests in influencing this piece of European private law, as well as the extent to which this endeavour proved successful.

Research indicated that the current pyramid scheme definition, as enshrined in the Unfair Commercial Practices Directive, represents the greatest success of the direct selling industry lobby in Europe, from the industry's perspective.

Based on considerable technical expertise and the demonstrated models of US federal- and state law, the industry advocacy was efficient in persuading the European legislator to follow the trend of US states, which was to move away from regulating legitimate MLMs. On the other hand, it succeeded in getting its proposed pyramid scheme definition adopted, almost verbatim. The definition of a pyramid promotional scheme that was put forward by the industry was as follows:

'Any plan or operation which a participant pays or promises to pay for the opportunity to receive compensation, which is derived mainly primarily from the person's introduction of other persons into a plan or operation, rather than from the sale of goods, ser- 
vices or intangible property, by the participant or other persons introduced into the plan or operation. ${ }^{786}$

From the perspective of the applied lobbying strategy, the participation of the World Federation of Direct Selling Associations (WFDSA), FEDSA and Amway added significant weight to the industry's position, providing European policymakers with a comparative legal analysis and a global overview and insight into doing business in the direct selling industry.

The industry lobby was extremely intensive and highly proactive throughout the pre-Commission phase; the pyramid scheme definition in the text originally proposed by the Commission (as influenced by the industry) was favourable to the sector and got adopted without any changes in the course of the legislative procedure:

'Establishing, operating or promoting a pyramid promotional scheme where a consumer gives consideration for the opportunity to receive compensation that is derived primarily from the introduction of other consumers into the scheme rather than from the sale or consumption of products.'

Looking at the substance of the legislative output, it is perhaps safe to say that while opting for the deregulation of MLMs did not cause considerable issues, the partial transplantation of the proposed pyramid scheme definition from US law to EU law did. The fact that the pyramid scheme definition's scope was narrowed down to B2C transactions and that it had been taken out of its natural context of US case law has rendered the current European pyramid regulation incomplete.

The scope of the pyramid scheme definition was narrowed down by the European legislator to B2C transactions only, through the replacement of the proposed term "participant" with the word "consumer", most probably to customise the definition to the scope of application of the UCPD. The consequence is that the European legislator has left schemes that masquerade as MLMs that rely on B2B transactions without civil law protection. For this reason, and because the CJEU interprets the notion of "consumer" strictly, ${ }^{787}$ schemes that operate on the basis of B2B transactions (such as pyramids that

\footnotetext{
${ }^{786}$ Study prepared on behalf of the Federation of European Direct Selling Associations by Oppenheimer Wolff and Donnelly LLP with the support of Amway Corporation, Brussels, March16, 1999, p.31.

${ }^{787}$ See relevant case law in Case C-150/77 Societe Bertrand v. Paul Ott KG [1978] ECR 1431; Case C-269/95 Francesco Benincasa v Dentalkit Srl. [1997] ECR I-3767; Case C-464/01 Johann Gruberv Bay Way AG [2005] ECR I-439; Case C-361/89 - Criminal proceedings v Patrice Di Pinto [1991] ECR I-01189 as well as the first paragraph of Article 13 and the first paragraph of Article 14 of the Convention [Article 15(1), point 1], and Article 16(1) of the Brussels I Regulation

${ }^{787}$ Case C-515/12 4finance UAB v Valstybine vartotoju teisiu apsaugos tarnyba and another [2014] WLR (D) 156
} 
try to pass themselves off as legitimate multi-level marketing companies) will never be caught by the current European pyramid scheme definition as enshrined in Item 14 Annex I of the UCPD. ${ }^{788}$

Secondly, the fact that the pyramid scheme definition (formulated on the basis of US federal law) was taken out of its original context of US case law, and was thus deprived of the safeguards developed by the American judiciary, ${ }^{789}$ only added insult to injury. The absence of entry- and exit requirements, the lacking safeguards against inventory loading (the guarantee of a buy-back policy), the failure to expressly prohibit earnings misrepresentations, the lack of a required retail sales rule (e.g. the famous Amway Safeguards Rule requiring direct sellers to sell a minimum of $70 \%$ of previously purchased products to end-consumers before placing a new order so as to limit distributors' personal consumption) and the missing regulation of internal consumption or referral sales only weaken the measure further.

By and large, it was concluded that, although the industry is content with the current wording, the inappropriateness of the present pyramid scheme definition simply begs for revision from a societal perspective. It is an ambiguous provision that fails to offer ample legal protection to potential victims of pyramid schemes, and by the nature of its obscurity and lack of clear guidelines to help distinguish MLMs from pyramids it leaves significant room for questionable marketing practices to flourish and fraudsters to operate.

The third dossier dealt with industry self-regulation and its role in shaping EU law. The direct selling industry is one of the few sectors that has established a world-wide voluntary normative framework governing its members' commercial conduct. Direct selling industry self-regulation has been examined in two areas. Firstly, as part of a global trend that raises industry standards through market integration, giving a comprehensive response to a general morality deficit and thereby attempting to pre-empt government intervention as a response to discrepancies, and, secondly, as an agent of European harmonisation, preceding and complementing statutory law.

Initially enacted by the US Direct Selling Association in response to two waves of marketplace abuses in the 1970s and in the early 1990s and the resulting reputational loss, as well as the fear of stringent legislative responses, the direct selling Codes of Ethics were adopted in Europe in 1995 by FEDSA (later Seldia) and, following the industry split, by Direct Selling Europe. The voluntary schemes serve as an umbrella of protec-

\footnotetext{
${ }^{788}$ The statement is in agreement with Dobson, P., 'Does the ban on pyramid promotional schemes challenge the business model of a typical direct selling company?', 2 Journal of Business Law, 2011, p. 194-207.

${ }^{789}$ See In re Koscot Interplanetary, Inc., 86 F.T.C. 1106 (1975) (FTC decision), In the Matter of Amway (93 F.T.C. 618) (1979), Webster v. Omnitrition International, 79 F.3d 776 (1996)
} 
tion in the form of a quasi-trust mark, since companies that undertake compliance with the voluntary Codes may be seen as trustworthy and honest traders. Hence, the industry's engagement in private regulation is motivated by self-interest, namely the need to improve its reputation, increase public trust and fend off significant external pressures the political threat of government intervention, market forces or the fear of hostile consumer NGOs- that may all point towards the adoption of more restrictive legislation and/or regulatory action. In this particular case, marketplace abuses and the conclusive fear of legislators' and law enforcement's reactions necessitated adherence to higher standards than before, wherefore the industry's engagement in self-regulation also serves the interests of consumers and direct sellers.

The second field of enquiry was devoted to the examination of direct selling selfregulation as an agent of harmonisation. The European Codes having been adopted as early as 1995, the mere existence of the direct selling sector's system of private norms can be viewed as testimony to the industry's desire of full harmonisation in Europe, preceding the actual full harmonisation directives the European legislator has put in place since 1995.

From an institutional perspective, the direct selling industry's sector-specific Codes have been found to both complement and substitute European law.

While the complimentary function of the direct selling industry's Codes of Conduct towards consumers was significantly more relevant before the entry into force of the Consumer Rights Directive, the Codes of Conduct towards direct sellers and companies, in line with the general trend, play a more significant role in supplementing targeted fields of European trade law. The Codes' prohibition of misleading earnings claims substantiates, whereas bans on inventory loading and referral sales as well as the prescription of a mandatory buy-back policy complement European unfair competition law and, more specifically, the pyramid scheme definition.

Lastly, in terms of complementing European law enforcement, Seldia's panEuropean ADR body, the European Code Administrator, established to handle complaints of consumers and traders falling under different jurisdictions, was highlighted as a unique initiative, creating a new forum of European cross-border consumer redress.

The fourth dossier concerned the direct selling industry's actions in terms of entrepreneurship promotion. Entrepreneurship advocacy is not a legislative lobbying dossier for the industry, yet it has nevertheless been included in the enquiry as a comprehensive PR venture. The second, equally important reason for the assessment of this nonlegislative lobbying dossier was its greatest shortcoming, the missed opportunity to incorporate legislative issues concerning the business environment and regulatory burdens of SMEs into the lobbying agenda. 
Entrepreneurship has received escalated attention from policymakers and economists during the global recession as one of the main ways to resolve the crisis. Having recognised entrepreneurship as an important source of innovation, growth and employment, boosting the establishment of start-ups and businesses has become a primary goal for government policies. However, while entrepreneurship has had a positive influence on the slack labour market in the United States, Europeans have proven to be less entrepreneurial, largely due to the fact that Europeans' level of risk tolerance is considerably lower than that of Americans. Further obstacles in the EU are caused by the fact that the business environment is not necessarily ideal for entrepreneurs in all Member States (due to red tape, strict bankruptcy laws or difficulties in access to finance), and that the existing legal fragmentation also poses issues of double taxation or other taxation mismatches.

The Seldia and Amway lobby in this field appears to deal with the former problem only, and solely from a PR perspective. Europeans' lower level of entrepreneurial spirit and risk-tolerance provided the industry lobby with an opportunity to redefine the image of direct selling, emphasising its entrepreneurial values and presenting direct selling companies as quasi-incubators that foster the establishment and operation of microand small businesses in a low-risk, but highly supportive environment.

Addressing the compromised reputation of the direct selling industry and reinventing its narrative tailored to the contemporaneous policy objectives and phraseology is perhaps the main aim of the industry advocacy, besides the establishment of relations with high-profile politicians and government officials by providing them support and a platform to reinforce political messages regarding the issue.

Looking at the specific advocacy tools, Amway, one of the largest direct selling companies, was found to be the pioneer of the industry's entrepreneurship promotion through the establishment of an annual academic research project on the economic value of entrepreneurship in Europe. It was the Amway research initiative that first started exploiting the possibilities which existed in this policy agenda, initiating political discourse with policymakers on various aspects of entrepreneurship while indirectly promoting direct selling.

The second field of examination was the women entrepreneurship advocacy campaign organised by Seldia, based around the fact that only one third of the self-employed in Europe are women and only around $30 \%$ of start-ups are run by women, ${ }^{790}$ whereas,

${ }^{790}$ Eurostat, 'Statistics in focus: the entrepreneurial gap between men and women' (30/2007) 
the vast majority (79\%) of direct sellers are female in the EU. ${ }^{791}$ In addition to the public events organised to promote women entrepreneurship and direct selling, a novel element of the industry lobby, the establishment of Seldia's first front group, the Women Entrepreneurship Platform (WEP), was described. The Platform was set up with a view to influence public policy and public opinion through this seemingly spontaneous grassroots organisation. The wide NGO support that the WEP enjoys adds to its credibility and influence, although it remains to be seen whether the WEP will be a purely public relations tool or if it will also be utilised for legislative lobbying purposes.

Seldia's entrepreneurship advocacy can be seen as a highly successful endeavour from a PR perspective on which DSE gets to freeride, but is more problematic from a societal perspective. The critique of the dossier was multi-fold. On the one hand, at the level of thematic choices, it is doubtful whether the dossier serves any other interests than that of the direct selling industry. It also ignores the highly relevant correlations between network marketing and low-skilled immigrants, and, on the other hand, it fails to address legislative lobbying issues, namely those concerning taxation of SMEs, in the portfolio. It has been highlighted that legal fragmentation and the lack of a level playing field means that there are not only significant differences in the regulatory burden SMEs have to face in various Member States, but also that cross-border transactions are hindered by double taxation as well as other taxation mismatches. From the perspective of SMEs, the promotion of these issues may be beneficial in fostering cross-border trade in the EU.

\subsection{Lobbying Techniques}

Following the legal enquiry into the direct selling industry's lobbying activity in the EU and based on the findings of the substantive assessment of the lobbying dossiers, the industry advocacy techniques were examined from the perspective of political sciences. To that effect, a comprehensive empirical research was conducted with the participation of various direct selling industry lobbyists. With a view to map the industry lobbying techniques in Brussels, semi-standardised qualitative interviews were conducted with three representatives of the two European direct selling lobby groups (two executives from Seldia and one from DSE), standardised interviews were conducted with corporate actors and a survey was carried out to map national direct selling associations' advocacy

\footnotetext{
791 The figure has been drawn from Seldia's statistical report from 2012. The statistics is not representative. Available on Seldia's website at: http://www.seldia.eu/sites/default/files/pdf-ocuments/2012\%20stat\%20general \%20presentation27062013\%20xls.pdf (last visited 17 September 2014)
} 
activity in the EU so as to complement the findings of the legal research into the industry's lobbying dossiers.

Lobbying is a hidden and non-observable political activity that affects political outcomes. ${ }^{792}$ Although certain measures (such as the publication of position papers or the establishment of the non-mandatory EU Transparency Register) have already been taken to shed more light on these hidden processes of Brussels advocacy democracy, substantial aspects of lobbying remain hidden behind closed doors, thus rendering it difficult for any researcher to fully explore this dimension of policymaking. Accordingly, due to the highly sensitive and confidential nature of the information the current inquiry sought to obtain, participation in the empirical research conducted between 2012 and the summer of 2014 was voluntary. Thus, the resulting samples were not entirely representative. Although both European trade associations participated in the project and were as forthcoming as they could possibly be under their confidentiality obligations, only a little over $40 \%$ of national associations returned the questionnaires; 3 out of the $6(50 \%)$ individually lobbying direct selling corporations in Brussels (one of which was represented by a consultancy) and two more of Seldia's remaining, exclusively collectively lobbying corporate members participated in the research. Results of the empirical research are therefore not representative of the entire population. Nevertheless, the trends indicated by the empirical research have shown considerable overlaps with the conclusions drawn based on the assessment of lobbying dossiers, thereby increasing the validity and credibility of the empirical research results.

In line with the public choice theory, the direct selling industry advocacy -like any other actor- was found to be an economically rational interest group looking to maximise its utilities. Lobbying is aimed at the advancement of self-interest wherefore if the interest group is capable of achieving advantages through advocacy it will do so, thus potentially distorting macroeconomic decisions.

Based on the three-dimensional theory of Lukes on power, ${ }^{793}$ it was discovered that direct selling lobbyists will attempt to impact all aspects of political power ${ }^{794}$ and policymaking. The first face of power involves political decision making per se, the second concerns the setting of political agenda (whether there should or should not be a decision on a certain subject), whereas the third dimension includes the shaping of policymakers' and the publics' perception - the political culture.

\footnotetext{
792 Originally stated by Lukes in Lukes, S., Power: A Radical View (Macmillan Publishing, Basingstoke, 1974) as cited by Svendsen, G. T., 'Evaluating and Regulating the Impacts of Lobbying in the EU? The Case Study of Green Industries', 21 Environmental Policy and Governance, Issue 2 (2011), p. 131-142, p. 139.

${ }^{793}$ Lukes, S., Power: A Radical View (Macmillan Publishing, Basingstoke, 1974)

${ }^{794}$ See Svendsen, G. T., 'Evaluating and Regulating the Impacts of Lobbying in the EU? The Case Study of Green Industries', 21 Environmental Policy and Governance, Issue 2 (2011), p. 131-142.
} 
Looking at the first dimension of power, political decision-making, the direct selling industry was analysed within the framework of the Beckerian model of competing lobby groups. It was shown how the free competition of interest groups amounted to a zerosum political game whereby the performance of a lobby group is relative to that of others and is primarily aimed at utility maximisation. Against this background, it was revealed that the outcome of deliberations concerning the Consumer Rights Directive was not a clear win for any of the parties involved, but was rather a new political compromise between the Commission and the industry interests of trade liberalisation on the one hand, and, on the other hand, consumer movements and Member States' that were fighting to retain both their competences and protectionist national measures. Analysis of this particular dossier also largely validated Becker's conclusion that political protection against changes in the private sector will likely be incomplete and temporary due to the fact that the increase of deadweight costs during the time of protectionist regulation will trigger periodic efforts at deregulation. ${ }^{795}$

Further, the comprehensive industry lobby for the deregulation of MLMs and the favourable wording of the pyramid scheme definition -whereby the industry did not face any significant opposition of competing lobby groups- has made the dossier the most successful lobbying venture for the direct selling industry yet. Moreover, the direct selling industry has subsequently managed to defend and sustain the present regulatory framework by efficiently influencing the European Commission's agenda setting and ensuring that a revision of the MLM/pyramid scheme regulation does not take place.

It was found that the two other scrutinised lobbying dossiers, self-regulation and the promotion of entrepreneurship, were both motivated by the direct selling industry's interest to improve its reputation and as such were aimed at shaping policymakers' and the general public's perception - the third dimension of power.

Ensuing stages of scrutiny have focused on the direct selling industry lobby's analysis from the perspective of Mancur Olson's group size theory. In particular, the industry advocacy proved to be an example for the Olsonian paradox in that a small group representing concentrated interests has a greater capability to carry out successful lobbying than a larger group with dispersed interests. This conclusion challenges the classic pluralistic theory that interest groups have an equal chance to participate in the political pressure system, thus also questioning whether the free competition of interest groups prevents the undue influence of certain advocacy groups. While this theory was used to explain the direct selling industry's successful influence on unfair competition law in particular, the study has revealed that an additional reason for interest groups' unequal

${ }^{795}$ Becker, G., 'Competition Among Pressure Groups', p. 372-383. 
chances of participation is also caused by the diverse political marketability of the interest or issue for which they advocate.

Direct selling corporations' participation in collective action is geared towards the advancement of the industry's common interests and typically succeeds through participation in trade associations and $a d$ hoc industry platforms. On the other hand, individual action is taken in the event that the company represents an individual interest, when the importance of the lobbying issue is such that it calls for reinforcement or in relation to domestic issues, the significance of which requires that the matter be escalated to European level.

In terms of the industry split, assessment of the lobbying dossiers has shown that strategic interests of the Seldia and DSE groups are largely identical and interviews with trade association representatives have revealed that the industry split indeed concerned original FEDSA members' selective incentives and the disproportionate capability of larger members to define common matters. The resulting prisoner's dilemma-type situation of the two European trade associations thus appears to be resolved (and sustained) by way of the two players' cooperation in advocacy in the strictest sense - both associations represent the same interests in key legislative lobbying issues such as the full harmonisation of consumer law, trade liberalisation or the pyramid scheme definition and MLM deregulation And yet, this cooperation does not exclude uncooperative conduct in other fields, such as the attempt to gain competitive advantage through the criticism of other companies' business models.

Interviews with corporate actors have revealed that engagement in various types of collective action serves various purposes in influencing political power. Membership in large trade associations, such as AmCham EU, is aimed at political agenda setting whereas small trade associations like Seldia, DSE or even ad hoc industry platforms have an increased potential to efficiently promote small, sectorial interests and thereby either influence policymakers' perception of the industry and/or to effectively influence political decisions.

Analysis of the results of legal research into the lobbying dossiers as well as empirical research into the lobbying techniques in light of Pieter Bouwen's access theory offered insight into the institutional access of the direct selling industry lobby. Bouwen established a comprehensive system modelling the interdependence that arises in cases where business interests and public actors rely on each other for the access of resources, ${ }^{796}$ and proposed a theoretical framework to explain the access of different organisational forms

\footnotetext{
${ }^{796}$ Bouwen P., 'Corporate lobbying in the European Union: towards a theory of access', 9 Journal of European Public Policy, Issue 3 (2002), p. 365-390.
} 
of business interest representation (companies, associations and consultants) to the European Commission, the European Parliament and the Council. The degree of access to these key European institutions is explained in terms of theory of supply and demand of access goods.

In a nutshell, Bouwen's theoretical model suggests that access to the supranational European Commission is greatest for European associations (43\%) as providers of aggregated European interests and for individual firms (34\%) that can provide technical expertise necessary for drafting legislation. Access to the European Parliament -an institution that is partly supranational with some intergovernmental features- is the highest for European associations (38\%) and national associations (37\%), the former providing information on European interests whereas the latter deliver knowledge about national interests. Lastly, the Council provides the greatest degree of access to national associations (43\%) and individual companies (37\%) due to their ability to provide information on national interests.

Empirical research has discovered that the industry advocacy tends to have the greatest influence on the European Commission, mainly thanks to the lobbying efforts of the European trade associations and individually lobbying corporations that are in the best position to provide this supranational institution with information on the aggregated European interests of the industry. There appeared to be less access to the European Parliament and especially to the Council, due to the fact that the present labour division within the direct selling industry advocacy renders it incapable of fulfilling its full potential. While the EP appeared to be lobbied by the European trade associations but only by half of the responding DSAs, the Council turned out to be lobbied mostly by the European trade associations. Actors that would have the greatest degree of access appeared to be slightly underperforming: while only half of the responding DSAs claimed to lobby the Council, none of the interviewed corporations said to do so.

Conclusions of the empirical research were found to be fully in line with the case studies of legislative lobbying in that while the industry advocacy does well at the preCommission stage, its performance at the post-Commission stages weakens significantly. This trend can be attributed to various factors. Firstly, from a substantial perspective, the Commission in general tends to be more receptive to industry interests, very often because this supranational institution promotes the establishment of the internal market and trade liberalisation, which is also the vital interest of the industry On the other hand, the European Parliament and Council are more politicised and thus less open to industry pleas. Secondly, it was found that in the post-Commission stages, but especially when lobbying the Council, the industry lobby does not fulfil its potential. 
Finally, strategic litigation is not a strategy that is pursued by the direct selling industry. While this type of interest representation strategy may be successfully used in promoting minority interests, and as such has proven to be an important tool of achieving trade liberalisation, the industry appeared to shy away from it, possibly due both to lack of coordination at the European level as well as to the defensiveness of the industry as a whole. 
Summary 
This dissertation is made up of legal and empirical research into the direct selling industry's advocacy in the European Union. In the context of the European pluralistic democracy or, somewhat pejoratively, the Brussels "lobbyocracy", the thesis intends to increase lobbying transparency by mapping how a particular interest group strives to influence European law in an effort to maximise its benefits. The research entails relevant findings at a macro level, from the perspective of democratic representation, as well as at a micro level, offering policy recommendations in each assessed policy field and thereby hoping to contribute to better regulation.

The first part of the analysis is a legal enquiry, looking at the substantial aspects and concrete areas of European law and policy that the direct selling industry aims to influence. Secondly, the research looks at the advocacy techniques from a political sciences perspective, mainly in the framework of the rational choice theory, assessing what aspects of political power the industry lobby targets and the degree of institutional access achieved through various advocacy actions.

The legal enquiry into the direct selling industry lobby focuses on key aspects of direct selling industry interests vs. other societal interests. It introduces the four main lobbying dossiers for the direct selling industry: the harmonisation of consumer law governing off-premises consumer contracts and trade liberalisation; the field of unfair competition law that draws the distinction between legal multi-level marketing (MLM) and illegal pyramid schemes; the role of industry self-regulation; and, lastly, the promotion of entrepreneurship. Each of these chapters describes the interests behind the respective advocacy strategies, assesses the extent to which lobbying has shaped or is trying to shape European legislation, reflects thereupon from a societal perspective and, consequently, entails policy recommendations.

Negotiations leading up to the adoption of the Consumer Rights Directive were an opportunity for the direct selling industry to advocate trade liberalisation and the abrogation of protective national measures through maximum harmonisation and the modernisation of consumer contract law governing direct selling in the EU. Testing the constitutional waters of the EU, intense political battles surrounding the adoption of the Directive clearly indicated the struggle between the industry-backed Commission ambitiously striving to codify the European consumer acquis on the one hand and, on the other hand, the Member States and consumer movements that were opposed to the dramatic redistribution of regulatory power and the reduction of consumer rights in more generous jurisdictions. The conclusion was a political compromise that permitted full harmonisation on a more reduced terrain than originally intended, bringing only electronic commerce and off-premises contracts under its scope. For the direct selling industry this meant an increased -but not the hoped-for full- liberalisation of trade and 
a more up-to-date legal framework. All in all, the industry lobby's success concerning this dossier was rather moderate, partly because of the constitutional issues the initiative raised that went far beyond the scope of direct selling advocacy; also because of the political compromises that had to be struck between consumer movements and the industry; and, lastly, because of the strategic malfunctions within the industry lobby that the research has shed light upon, such as the lack of discipline amongst the industry's lobbyists or the strikingly low level of national direct selling trade associations' participation in the overall advocacy strategy.

While aspirations to influence the Consumer Rights Directive resulted in moderate achievements for the industry, direct selling advocacy was found to have been most successful in achieving industry interests in a very specific terrain: multi-level marketing de-regulation and the European pyramid scheme definition. Drawing the distinction between legitimate MLMs and illegal pyramid schemes, this area of unfair competition law is of pivotal importance for the direct selling industry. In general, the clearer and tighter the rules governing pyramid schemes are, the easier it is to distinguish legitimate businesses from frauds. The wording of the current European pyramid scheme definition -as enshrined in the Unfair Commercial Practices Directive- was proposed and advocated for by the concentrated and well-organised industry lobby in a political arena where opposing interests were not very vocal at the time. Although, naturally, the industry is content with the current wording and leaves no stone unturned to oppose the revision thereof, it was concluded that the inappropriateness of the present pyramid scheme definition simply begs for improvement from a societal perspective. Namely, the present European pyramid scheme definition is an ambiguous provision that fails to offer ample legal protection to potential victims, such as small businesses, who join these schemes (which are usually disguised as legitimate MLMs and as such are based on B2B contractual relations), since its scope of application is restricted to B2C relations. Sadly, only the most amateur scammers base their schemes on B2C relations, however, which means that victims of sophisticated frauds are left without civil law protection. The conclusion is that, due to its limited scope, obscurity and lack of clear guidelines, the current European pyramid scheme regulation leaves significant room for questionable marketing practices to flourish and fraudsters to proliferate.

The third dossier dealt with industry self-regulation and its role in shaping European law. The direct selling industry is one of the few sectors that established a world-wide voluntary normative framework governing its members' commercial conduct. Two areas of the industry's self-regulation have been examined. Firstly, as part of a global trend that raises industry standards through market integration, giving a comprehensive response to a general morality deficit and thereby attempting to pre-empt government 
intervention as a response to discrepancies. And, secondly, as an agent of European harmonisation, complementing statutory law. It was found that, with the evolution of European law, the role self-regulation plays in complementing statutory law has decreased. However, it still offers some, but not necessarily sufficient, complements to the European pyramid definition.

Although not a legislative lobbying dossier, the promotion of entrepreneurship is dear to the direct selling industry as a sector that aims to provide opportunities for small businesses to sell products of the parent company for extra profit. Entrepreneurship promotion is crucial for the industry in addressing the compromised industry reputation and building alliances with European policymakers who see entrepreneurship as the tool to combat the global economic crisis. The industry's entrepreneurship advocacy is undoubtedly a successful PR endeavour but was criticised from a societal perspective for a multitude of reasons. Firstly, at the level of thematic choices, it is doubtful whether the cleverly planned and executed lobbying actions serve any other interests than those of the direct selling industry. Secondly, the strategy largely ignores the highly relevant correlations between network marketing and low-skilled immigrants, an issue that is high on the current political agenda. Furthermore, the dossier fails to address legislative issues, namely those concerning the establishment of a more harmonised economic environment for SMEs.

Based on the case-studies of the lobbying dossiers as well as on overarching -but not fully representative- empirical research conducted with the participation of various actors of direct selling lobbying, the second main part of the dissertation examines the advocacy techniques of various industry actors (European and national trade associations, corporate- and third party lobbying) from a political sciences perspective. In terms of institutional access, it was discovered that the industry advocacy tends to have the largest influence on the European Commission, mainly thanks to the lobbying efforts of the European trade associations and individually lobbying multinational corporations that are in the best position to provide this supranational institution with information on the aggregated European interests of the industry. There appeared to be less access to the European Parliament and especially to the Council, due to the fact that the present labour division within the direct selling industry advocacy cannot rely on its national trade associations' efficient lobbying, and thus renders it incapable of fulfilling its full potential.

All in all, the research may be viewed as offering insight into the substantial and technical aspects of strategic interest representation in the European Union through the mapping of an important, albeit deeply controversial, advocacy group's political strategy and organisational structure. 


\section{Valorisation Addendum}




\section{Social Relevance of the Research}

A study looking into the legal and empirical aspects of how an organised interest group influences the European legislature -the originator of approximately $80 \%$ of laws within the European Union- has societal relevance in two main respects.

From a democratic perspective, the research helps to increase lobbying transparency by providing insight into this cross-section of the European political system. In this sense, the enquiry reveals how a particular advocacy group strives to maximise its benefits against competing interest groups and the extent to which it manages to realise its interests. In other words, the study elucidates the way lobbying manifests itself in European legislation governing a certain industry sector, raising questions of democratic representation, social justice and morality. While lobbying usually has a negative connotation, in case the representation of interest groups is balanced it may actually result in legislative output that is more widely accepted. The example brought forward in this study for such balanced representation of interests from a consumer- and industry perspective is the Consumer Rights Directive, an act that represents a number of political compromises and concessions but is nonetheless acceptable for both consumers and the industry. On the other hand, imbalance of lobbying entails the risk of distortion, resulting in legislation that favours only one interest group and disadvantages other, less vocal or organised interests, as was the case with the largely industry-proposed European pyramid scheme definition.

From a policy perspective, the dissertation offers recommendations in each area it assesses.

While the Consumer Rights Directive was found to strike a good balance between consumer- and industry interests in general, it may be questionable whether it will manage to liberalise trade between Member States at the intended level. Save where otherwise provided by the Directive, the maximum harmonisation nature of this piece of legislation should provide the legal basis for the abrogation of national protectionist measures restricting direct selling and electronic trade, yet considerable changes have not been observed in the national regimes in this respect since the entry into force of the Directive.

In terms of MLM de-regulation and the European pyramid scheme definition, the area of unfair competition law that has been somewhat distorted by the direct selling industry lobbying, several recommendations have been made. While the industry's present position is that the pyramid scheme regulation is appropriate and does not need revision, this study suggests that the current norm is incomplete; not only is it very generic and ambiguous, its scope has also been narrowed down to $\mathrm{B} 2 \mathrm{C}$ transactions. As a 
result, it is incapable of catching the vast majority of pyramid promotional schemes that are masqueraded as legitimate MLMs, which are per definition B2B structures wherefore it does not offer protection to small businesses that may be defrauded by scammers. In conclusion, it is recommended that tighter rules and specific safeguards be put in place to reduce the grey area between legitimate MLMs and fraudulent schemes in which pyramids and questionable market practices can proliferate. To that end, the scope of the pyramid definition should be extended to B2B schemes and a clear set of rules should be introduced instead of the current ambiguous and generic pyramid scheme regulation. In concreto, high entry fees and inventory loading should be prohibited, outrageous and unsubstantiated earnings claims should be expressly outlawed, a buy-back policy and requirements of customer sales (to ensure that sales are predominantly outside the scheme) need to be put in place.

Direct selling industry self-regulation in Europe is part of a global trend that raises industry standards through market integration, but it is also a comprehensive response given to a general morality deficit, placed in the context of an increasingly harmonised economic and legal environment. As an agent of European harmonisation, the direct selling industry's Codes of Conduct have been found to have played a key role, especially before the entry into force of the Unfair Commercial Practices Directive and the Consumer Rights Directive, in complementing European consumer law. While there are no longer considerable gaps to fill in terms of the consumer acquis, the body of law governing transactions between businesses (between direct selling companies and between direct selling companies and direct sellers) is in need of supplementation. The ambiguous anti-pyramid statute of EU law is -to some extent-complemented in its scope by direct selling private regulation, as the industry Codes provide direct sellers protection through the provision of specific safeguards that EU law falls short of, particularly in the field of unfair competition law. In this respect, it is suggested that the industry Codes be viewed as a pool of sector-specific knowledge that the European legislators could avail themselves of as a basis for the revision of the pyramid scheme regulation.

From a societal perspective, the entrepreneurship campaign of the industry raises policymakers' and the general public's awareness of the field as well as of direct selling as an opportunity to make extra income. On the other hand, however, the campaign is geared towards serving the industry's interests in both advertising the industry as well as in creating an opportunity for the industry to build bridges with politicians. In that respect, the industry lobby was criticised for not addressing two key areas: the opportunities network marketing offers for immigrants and the promotion of better regulation for SMEs. It is therefore recommended that the economic potential that network marketing holds for the sharply rising number of immigrants, even those less skilled, be 
explored. Studies suggest that the underlying reasons for immigrants becoming engaged in network marketing is a positive environment, self-efficiency and the desire for opportunities, which, accelerated by human capital, is positively related to financial performance outcomes. ${ }^{797}$ Furthermore, lower qualified migrants, even those who do not speak the host country's language and are disadvantaged on the employment market, can start their direct selling businesses and operate within their own cultural enclaves in the host country successfully.

Secondly, as revealed by empirical research into direct selling corporate interest representation, the promotion of entrepreneurship should call for concrete action in the field of the consolidation of tax rules, i.e. the Commission proposal (COM (2001) 582) regarding the establishment of a common consolidated corporate tax base (CCCTB) to improve the legislative environment of small businesses (direct sellers) especially.

\section{Audience Besides Academic Community}

An audience that could be particularly interested in the results of this research is that of European policymakers. The enquiry into a particular interest group's advocacy actions may help increase politicians' understanding of the potential as well as the risks of lobbying from the perspective of democratic representation. Furthermore, the analysis of the extent to which the normative framework governing the direct selling industry was influenced by various interest groups can contribute to a more informed evaluation thereof and, potentially, the revision and/or more efficient enforcement of certain norms.

Naturally, the direct selling industry and, in particular, its lawyers and lobbyists can benefit from the findings of the thesis. The analysis contained in the legislative enquiry can serve as a compass in a multitude of strategic issues such as the problem of trade liberalisation, the pyramid scheme regulation or the entrepreneurship dossier. The criticism directed at the industry is hoped to be constructive in that it might not serve the industry's short-term interests at all, but may well contribute to improving the industry's advocacy from a substantial perspective and, more importantly, the critique is meant to encourage the quest for the right response to the inherent morality deficit that the network marketing industry has constantly battled with. On the other hand, the empirical research of the industry's lobbying techniques reveals both the successful aspects as well as the systematic flaws of the sector's Brussels advocacy, which may thus

${ }^{797}$ Fu Dai, A Model of Network Marketing Business Entrepreneurial Performance, 2012, p. 24. 
be the basis for the implementation of corrective measures aimed at the increase of lobbying efficacy.

Lastly, lawyers, public affairs professionals of other sectors, as well as the general public may also take an interest in the dissertation. By referring to the results of this thesis, the audience can acquire general knowledge about the interests that have shaped particulars field of European law, how interest groups aim to influence policymakers and what advocacy techniques are used to that end.

\section{Publication of the Research Results}

Firstly, the present research is published as a book by Maastricht University's printer Datawyse in preparation for the public defence of the thesis.

Furthermore, drafts of some parts of this thesis have been published in the last few years on the Social Sciences Research Network (Maastricht European Private Law Institute Research Paper Series) in order to elicit comments.

The section on the bans on payment and the bans on sales has been published in the article entitled 'The (In)compatibility of Direct Selling Trade Barriers with EU Law' which discussed the conflict of interest between the liberalisation of trade as regards the direct selling industry and Member States' freedom to impose stringent regulations in order to favour consumers' economic interests. The paper assesses direct selling trade barriers' compatibility with European law, and in particular, the fundamental freedoms of the internal market and the relevant secondary law regulating consumer protection, fair trading law and the provision of services.

It is envisaged to publish further parts of the thesis as articles after the defence has taken place.

\section{Innovativeness of the Research}

While an increasing number of research projects are aimed at studying lobbying in the European Union, the present work is the only one (to the author's knowledge) that provides a comprehensive overview of the direct selling industry's advocacy towards Brussels policymakers.

In this respect, the study's innovative nature is twofold. Firstly, from the perspective of legal research, the novel element is the detailed analysis of the specific interests, posi- 
tions and legislative proposals that have been put forward by the direct selling industry in the course of its advocacy activities within the context of competing interests and the assessment of the extent to which these interests have materialised in legislative output, thereby shaping the norms of European private law and policy.

The second innovation concerns the systematic exploration of the direct selling industry's lobbying methods in the Brussels political arena from a political sciences perspective. It is the first overarching (albeit not representative) empirical research that has been carried out to examine and analyse the -at times hidden, or at least less visiblemeans through which the industry's various forms and organisations of interest representation attempt to influence policymakers.

In summary, this $\mathrm{PhD}$ maps both the substantial as well as the technical aspects of the direct selling advocacy in Brussels, contributing to the current literature and aiming at increasing the openness of the European decision making process.

\section{How will this/these valorisation plan(s) be shaped}

The research results may be offered to European policymakers and, in particular, to the European Commission, in order for legislators to be able to gain a better understanding of the actual impact of lobbying on overall legislative- and policy outcomes, as well as the implications for the democratic representation thereof. The paper could contribute to the mapping of areas where European law could be revised or better implemented.

Findings of the study can be made available to lawyers, lobbyists and public affairs consultants both within as well as outside the direct selling community. The paper provides a unique and valuable overview of the state of affairs of the direct selling industry's government affairs professionals, reflecting on both the positive aspects as well as on areas where there is room for improvement. On the other hand, advocacy experts outside the direct selling industry may also take away important findings from the research in terms of the efficient division of labour between lobbying actors and the role national trade associations could and should play in European interest representation.

The analysis may provide the basis of future research into how the distorting effects of lobbying may be reduced on a systematic level and what new types of checks and balances could be put in place to increase the transparency and democraticness of the "Brussels lobbyocracy". 


\section{European Direct Selling Trade Association Representatives' Interview Questions}

1. Can you please describe the trade association that you represent?

2. Do you have any general observations about lobbying for the direct selling industry?

3. In your opinion, what was the reason for the industry advocacy's (FEDSA) split?

4. How would you distinguish Direct Selling Europe from Seldia?

5. Does the association you represent serve as a self-regulatory body?

6. How would you summarise the aim and the main points of the association's Code of Conduct?

7. How does the trade association ensure compliance with its Code of Conduct?

8. How would you evaluate the Consumer Rights Directive?

9. How would you evaluate your trade association's advocacy concerning the Consumer Rights Directive?

10. What is your association's position on the full harmonisation nature of the CRD and minimum harmonisation clauses like Recital 13?

11. What is the association's position on trade barriers?

12. What is the association's position on the UCPD and the MCAD and the revision thereof?

13. What is the association's position on the CESL?

14. What is the association's position on the TTIP?

15. How would you characterize the association's lobbying strategies? (Negative [a strategy of opposing, blocking and refusing, but without proposing any credible alternatives] --- Defensive (the strategy is about defending an advantage that the firm has gained and opposing any evolution in the legislation) --- Reactive (based on waiting, taking no action and having no strategy) --- Pro-active (usually anticipatory, dedicated [with strong convictions, involvement, partnership], based on the pursuit of an acceptable solution)?

16. Does the association have an established network with the European institutions?

17. Does the association tend to target higher- or lower level officials when lobbying?

18. Does national affiliation play a role in networking with political institutions?

19. Does political affiliation play a role in networking with political institutions?

20. Do the association's national associations and/or corporate members lobby in Brussels?

21. Does the association lobby at national level?

22. Does the association organise lobbying events?

23. Are there any constraints to the association's advocacy (be it budgetary or the image of the industry)? If yes, to what extent do the constraints influence lobbying strategies?

24. Does the association build coalitions and/or ad hoc industry platforms? 


\section{Annex II}

\section{Questionnaire for Direct Selling Associations on Direct Selling Industry Lobbying in the European Union}

1. Which Direct Selling Association do you represent?

2. What size is your Association? (Number of full time staff)

3. Does your Association employ public affairs experts/trained lobbyists?

4. In your opinion, would it be useful if DSE/Seldia provided more assistance in national lobbying activities or is lobbying national governments the sole responsibility of DSAs?

5. Does your Association articulate national industry interests towards the European Commission? If yes, please provide an example.

6. Does your Association articulate European industry interests towards the European Commission? If yes, please provide an example.

7. Does your Association articulate national industry interests towards the European Parliament (your national Members of the European Parliament)? If yes, please provide an example.

8. Does your Association articulate European industry interests towards the European Parliament (your national Members of the European Parliament)? If yes, please provide an example.

9. Does your Association articulate national industry interests towards the Council of Ministers (your national representatives in the Council)? If yes, please provide an example.

10. Does your Association articulate European industry interests towards the Council of Ministers (your national representatives in the Council)? If yes, please provide an example.

11. Has your Association ever tried to persuade its national government to intervene in a case before the Court of Justice of the European Union? If yes, please provide an example. 


\section{Annex III}

\section{Corporate Lobbying Strategies of Multinational Companies in the Field of Direct Selling Questionnaire}

1. The firm's public affairs management

- How many European Public Affairs Managers does the firm employ? (Does the firm work with law/lobbying firms or think tanks to that end?)

- What are the responsibilities of the Public Affairs Managers'?

- Who do the Public Affairs Managers report to?

2. Network

- Does the firm have an established network with European political institutions?

- Is it the higher- or lower level officials that are being targeted?

- Does political affiliation play a role in networking with political institutions?

- Does the firm have contacts with other companies?

- Does the firm have contacts with NGOs?

- Does the firm have contacts with think tanks?

- Does the firm have contacts with law firms?

- Does the firm have contacts with the media/accredited press?

- Does the firm have contact with trade associations?

- In terms of networks, does the firm favour upstream or downstream networks?

3. Monitoring legislation and business intelligence

- Which dossiers/fields are being monitored?

- In which ways does monitoring succeed? (website, personal contacts with the actors concerned, technical experts, business intelligence)

- Are reports/newsflashes written, and if yes, how often?

- What is the audience of the reports?

- How does the analysis of the obtained information succeed?

4. Communication tools

- How important do you consider the role of position papers in lobbying?

- Are position papers adapted to the institution lobbied and the phase of the lobbying procedure or is it a more static document?

- Does the firm issue press releases on a regular basis? 
- Does the firm organise media campaigns?

- Does the firm organise lobbying campaigns?

- Does the firm organise public events to enhance its visibility?

5. Intervention and Lobbying strategies

- Which are the issues of particular importance in which the firm deems it necessary to act?

- Are actions and strategy firm or rather flexible?

6. Is the lobbying strategy: - Negative (a strategy of opposing, blocking and refusing, but without proposing any credible alternatives?) - Defensive (the strategy is about defending an advantage that the firm has gained and opposing any evolution in the legislation)? - Reactive (based on waiting, taking no action and having no strategy)? - Pro-active (usually anticipatory, dedicated [with strong convictions, involvement, partnership], based on the pursuit of an acceptable solution)?

\section{Liaison with political institutions}

- Does the firm approach the European Parliament (rapporteur/shadow rapporteur, MEPs [with a particular interest in the dossier], the coordinators of political groups, certain particularly active parliament officials, several permanent administrators of the Committees concerned?)

- Does the firm approach the Commission (the Unit or DG responsible, or both)?

- Does the firm approach the Council of Ministers (Does the firm ever lobby the latter? Membership in any expert groups, direct involvement in the work of the Council of Ministers?)

- Does the firm approach the Economic and Social Committee? (Lobbyists here are an integral part of deliberation, involved at the start of the first reading - can have a leveraging effect on the Parliament and the Council)

- Does the firm tend to intervene during the proposal phase by locating the rapporteur?

- Does the firm intervene at the first or second reading or the Conciliation phase?

- Is there any intervention at the execution phase (Comitology)?

\section{Constraints}

- To what extent do certain constraints influence lobbying strategies?

- Is the mandated lobbyist the master of the dossier?

- Are there budgetary constraints? If yes, is that an insurmountable obstacle or can the firm still win the dossier?

9. Coalitions - Trade associations:

- In which trade associations is the firm a member?

- Is the firm a member in both national and Brussels trade associations?

- Is the firm also a direct member in Brussels trade associations?

- Does the membership in trade associations enhance lobbying powers?

- Is there a division of tasks between the trade association and the individual firms?

- If relevant: has AmCham promoted the firm's interests better than the other Brussels trade associations?

- Does the firm tend to form ad hoc industry platforms when confronted by heavy lobbying dossiers? 


\section{Bibliography}

\section{EU Materials}

\section{Treaties}

Lisbon Treaty (TFEU)

TFEU Protocol (No. 1) on the Role of National Parliaments in the European Union

TFEU Protocol (No. 2) on the Application of the Principles of Subsidiarity and Proportionality

\section{Directives, Regulations, Decisions}

Brussels I Regulation - Council Regulation (EC) No 44/2001 of 22 December 2000 on jurisdiction and the recognition and enforcement of judgments in civil and commercial matters

Brussels Convention on Jurisdiction and the Enforcement of Judgments in Civil and Commercial Matters 1968

Council Directive 85/577/EEC of 20 December 1985 to protect the consumer in respect of contracts negotiated away from business premises [1985] OJ L 372

Council Directive 86/653/EEC of 18 December 1986 on the coordination of the laws of the Member States relating to self-employed commercial agents [1986] OJ L 382

Council Directive 93/13/EEC of 5 April 1993 on unfair terms in consumer contracts [1993] OJ L 95

Directive 2005/29/EC of the European Parliament and of the Council of 11 May 2005 concerning unfair business-to-consumer commercial practices in the internal market and amending Council Directive 84/450/EEC, Directives 97/7/EC, 98/27/EC and 2002/65/EC of the European Parliament and of the Council and Regulation (EC) No 2006/2004 of the European Parliament and of the Council ("Unfair Commercial Practices Directive") (Text with EEA relevance) [2005] OJ L 149

Directive 2006/114/EC of the European Parliament and of the Council of 12 December 2006 concerning misleading and comparative advertising (codified version) (Text with EEA relevance) [2006] OJ L 376

Directive 2006/123/EC of the European Parliament and of the Council of 12 December 2006 on services in the internal market [2006] OJ L 376

Directive 2011/83/EU of the European Parliament and of the Council of 25 October 2011 on consumer rights, amending Council Directive 93/13/EEC and Directive 1999/44/EC of the European Parliament and of the Council and repealing Council Directive 85/577/EEC and Directive 97/7/EC of the European Parliament and of the Council Text with EEA relevance, [2011] OJ L 304

Regulation (EC) No 593/2008 of the European Parliament and of the Council of 17 June 2008 on the law applicable to contractual obligations (Rome I) OJ L 177, 4.7.2008 


\section{Legislative Proposals}

Proposal for a Directive Of The European Parliament And Of The Council on consumer rights $\{$ SEC(2008) $2544\}\{$ SEC(2008) 2545\}\{SEC(2008) 2547\} COM(2008) 614 final, 2008/0196 (COD), Brussels 8.10.2008.

European Commission, The Proposal For A Directive On Consumer Rights: Impact on Level of National Consumer Protection Comparative Table (Draft), Brussels 9 October 2009

\section{Other EU Materials}

Commission Recommendation of 7 April 1992 on Codes of practice for the protection of consumers in respect of contracts negotiated at a distance (distance selling) OJ L 156/21

Council of the European Union: Council agrees on general approach for consumer rights, Brussels, 24 January 2011, 5426/11, PRESSE 7

European Commission, DG Health and Consumer Protection: Hearing: Door to door selling-Pyramid schemes-Multi-Level Marketing, Analysis of the written submissions prior to the Commission's hearing and the statements made during the Commission's hearing 15-16 March 2000, Brussels, http://www.scribd.com/doc/38555103/European-Commission-on-Multi-level-marketing-and-Pyramidschemes (last visited 7 September 2014)

European Commission, Follow-up Communication to the Green Paper on EU Consumer Protection, Brussels 11 June 2002, COM (2002) final 289

Commission of the European Communities, Communication From The Commission To The Council, The European Parliament, The European Economic And Social Committee And The Committee Of The Regions Action Plan: The European agenda for Entrepreneurship European Commission, The Action Plan: The European Agenda for Entrepreneurship, Brussels, 11 February 2004, COM (2004) 70 final

European Commission, Consumer Policy Programme 2002-2006, COM (2002)208, OJ 2002, C137/2

Discussion Paper On The Review Of Directive 85/577/EEC to protect the consumer in respect of contracts negotiated away from business premises (Doorstep Selling Directive) http://ec.europa.eu/consumers/ cons_int/safe_shop/door_sell/doorstepselling_discussionpaper.pdf (last visited 17 September 2014)

European Commission, Report on the Models To Reduce The Disproportionate Regulatory Burden On SMEs, May 2007, Brussels, http://ec.europa.eu/enterprise/policies/sme/files/support_measures/regmod/reg mod_en.pdf (last visited 17 September 2014)

Commission Staff Working Document Accompanying document to the Proposal for a Directive Of The European Parliament And Of The Council on the protection of consumers in respect of certain aspects of timeshare, long-term holiday products, resale and exchange IMPACT ASSESSMENT \{COM(2007) 303 final\} \{SEC(2007) 744\} Brussels, 7 June 2007.

Working Document of the Commission: Responses to the consultation on the Council Directive 85/577/EEC of 20 December 1985 to protect the consumer in respect of contracts negotiated away from business premises - Summary of Responses between October 2007 and January 2008, http://ec.europa.eu/con sumers/archive/rights/docs/finalsummary30052008.pdf (last visited 17 September 2014)

Commission of the European Communities, Communication From The Commission To The Council, The European Parliament, The European Economic And Social Committee And The Committee Of The Regions “Think Small First” A “Small Business Act” for Europe \{SEC(2008) 2101\} \{SEC(2008) 2102\}, Brussels, 25 June 2008, COM(2008) 394 final 
Communication From The Commission To The European Parliament, The Council, The European Economic And Social Committee And The Committee Of The Regions Think Small First A Small Business Act for Europe Impact Assessment \{COM(2008) 394\} \{SEC(2008) 2102\}SEC(2008) Brussels, SEC(2008) 2101

European Commission - DG Enterprise and Industry, Evaluation on Policy: Promotion of Women Innovators and Entrepreneurs, submitted by the E E C (GHK, Technopolis) within the framework of ENTR/04/093FC-Lot 1 July 2008

Commission of the European Communities, Commission Staff Working Document accompanying the European Commission, Commission Staff Working Document, Guidance on the implementation/application of the Directive 2005/29/EC on unfair commercial practices, SEC (2009) 1666, Brussels, 3 December 2009

European Commission Press Release, European Commission adopts landmark list of permitted health claims, Reference: IP/12/479, 16 May 2012

Council of the European Union, Council agrees on general approach for consumer rights, Brussels, 24 January 2011, 5426/11, PRESSE 7

European Economic and Social Committee: INT/654 Direct sellers, Working Document of the Section for the Single Market, Production and Consumption on Direct sellers: the specific case of economically independent self-employed workers, 10 October 2012

European Commission, 'A Recovery on Horizon?', Annual Report on European SMEs 2012/2013

European Commission, Communication From The Commission To The European Parliament, The Council, The European Economic And Social Committee And The Committee Of The Regions: Entrepreneurship 2020 ACTION PLAN - Reigniting the entrepreneurial spirit in Europe European Commission, Entrepreneurship 2020 Action Plan, Brussels, 9 January 2013, COM(2012) 795 final

European Commission, First Report on the application of Directive 2005/29/EC of the European Parliament and of the Council of 11 May 2005 concerning unfair business-to-consumer commercial practices in the internal market and amending Council Directive 84/450/EEC, Directives 97/7/EC, 98/27/EC and 2002/65/EC of the European Parliament and of the Council and Regulation (EC) No 2006/2004 of the European Parliament and of the Council ('Unfair Commercial Practices Directive') Brussels, 14 March 2013, $\operatorname{COM}(2013) 139$ final

The Internal Market after 1992: Meeting the Challenge. Report presented to the Commission by the High Level Group on the Functioning of the Internal Market, presided by Peter Sutherland - October 28, 1992

\section{Cases of the Court of Justice of the European Union}

\section{Case 8/74 Procureur du Roi v Dassonville [1974] ECR 837}

Case 150/77 Societe Bertrand v. Paul Ott KG [1978] ECR 1431

Case 120/78 Rewe Zentrale v Bundesmonopolverwaltung fur Branntwein ("Cassis de Dijon“) [1979] ECR 649

Case C-382/87 R. Buet and Educational Business Services (EBS) v Ministère public [1989] ECR1235

Case C-152/84 Marshall v Southampton and South West Area Health Authority [1986] ECR I-4367

Case C-76/90 Saeger v Dennemeyer \& Co. Ltd. [1991] ECR I-4221

Opinion Advocate General: Opinion of Advocate General Jacob in Case C-76/90 Saeger v Dennemeyer \& Co. Ltd. [1991] ECR I-4221

Case C- 373/90 Criminal Proceedings against Nissan [1992] ECR I-131

Case C-126/91 Schutzverband gegen Unwesen in der Wirtschaft v Yves Rocher [1993] ECR I-2361

Joined cases C-267/91 and C-268/91. Criminal proceedings against Bernard Keck and Daniel Mithouard. [1993] ECR I-6097

Case C-210/96 Gut Springenheide v Oberkreisdirektor Steinfurt [1998] ECR I-1923 


\section{A Legal and Empirical Investigation Into the Direct Selling Industry’s Advocacy in the EU}

Case C-91/92 Faccini Dori v. Recreb [1994] ECR I-3325

Case C-412/93 Leclerc-Siplec v TFI Publicite [1995] ECR I-179

Opinion Advocate General: Opinion of Advocate General Jacob in Case C-412/93 Leclerc-Siplec v TFI Publicite [1995] ECR I-179

Case C-470-93 Verein gegen Unwesen in Handel und Gewerbe Köln eV v. Mars [1995] ECR I-1923

Case C-423/97 Travel Vac v. Manuel Jose Antelm Sanchis [1999] ECR I-2195

Case C-303/97 Verbraucherschutzverein v Sektkellerei Kessler [1999] ECR I-513

Case C-220/98 Lifting - Creme [2000] ECR I-117

Case C-254/98 Schutzverband gegen unlauteren Wettbewerb v TK-Heimdienst Sass GmbH. [2000] ECR I-151

Case C-376/98 Tobacco Advertising I [2000] ECR I-8419

Case C-324/99 DaimlerChrysler [2001] ECR I-9897

Case C-481/99 Georg Heininger and Helga Heininger v. Bayerische Hypo- und Vereinsbank AG [2001] ECR I9945

Case C-112/99 Toshiba Europe v Katun Germany [2001] ECR I-7945

Case C-322/01 Deutscher Apothekerverband eV v 0800 DocMorris NV [2003] ECR I-14887

Case C-44/01 Pippig Augenoptikv Hartlauer [2003] ECR I-3095

Case C-112/00 Schmidberger, Internationale Transporte und Planzuge v Republic of Austria [2003] ECR I-5659

Opinion Advocate General: Opinion of Advocate General Jacob in Case C-112/00 Schmidberger, Internationale Transporte und Planzuge $v$ Republic of Austria [2003] ECR I-5659

Case C-20/03 Criminal proceedings against Marcel Burmanjer and Others [2005] ECR I-4133

Case C-350/03 Elisabeth Schulte, Wolfgang Schulte v Deutsche Bausparkasse Badenia AG [2005] ECR I-09215

Case C-464/01 Johann Gruber v Bay Way AG [2005] ECR I-439

Case C-441/04 A-Punkt Schmuckhandels GmbH v Claudia Schmidt [2006] ECR I-2093

Case C-470/03 A.G.M.-COS.MET Srl versus Suomen valtio and Tarmo Lehtinen [2007] ECR I-2749

Case C-381/05 De Landtsheer Emmanuel SA v CPVC and Veuve Clicquot Ponsardin SA [2007] ECR I-3115

Case C-412/06 Annelore Hamilton v. VolksbankFilder [2008] ECR-I-2383

Case C-533/06 O2 Holdings Ltd v Hutchison 3G UK Ltd [2008] ECR I-4231

Case C-487/07 L'Oréal v Bellure [2009] ECR I-05185

Opinion Advocate General: Opinion of Advocate General Mengozzi at para. 84 in CJEU, Judgment from 18th June 2009 - Case C-487/07 L'Oréal/Bellure

Case C-261/07 and C-299/07 VTB-VAB NV v Total Belgium NV and Galatea BVBA v Sanoma Magazines Belgium NV [2009] ECR-2949

Case C-540/08 Mediaprint Zeitungs- und Zeitschriftenverlag v. Osterreich Zeitschriftenverlag [2010] ECR I0000

Case C-58/08 Vodafone, O2 et al v. Secretary of State [2010] ECR I-4999

Case C-421/12 Commission versus Belgium [2014] EUECJ

Case C-515/12 4finance UAB v Valstybine vartotoju teisiu apsaugos tarnyba and another [2014] WLR (D) 156 


\section{International Material}

\section{United States Case Law}

In the Matter of Amway Corporation, Inc., et al. 93 F.T.C. 618 (1979)

FTC Complaint in the Matter of Amway Corporation, Inc. et al. 93 F.T.C. 618 (1979)

93 F.T.C. 618: Opinion,

93 F.T.C. 618: Final Order

Koscot Interplanetary Inc., 86 F.T.C. 11106 (1975)

Webster v. Omnitrition International, 79 F.3d 776 (1996) 79 F.3d 776

FTC v. BurnLounge, U.S. Court of Appeals, Ninth Circuit (2014)

Federal Register, Revised Proposed Business Opportunity Rule, 16 C.F.R. 437 (proposed March 18, 2008)

\section{Member State Material}

Austria: Gewerbeordnung 1994 - GewO 1994; StF: BGBl. Nr. 194/1994 (WV)

Belgium: Belgian Code on Economic Law

Denmark: Act on Certain Consumer Contracts - Act No. 451 of 9 June 2004

France:

- Law No 72-1137 of 22 December 1972 on the protection of consumers regarding canvassing and door-todoor selling (Official Gazette of the French Republic of 23 December 1972)

- French Consumer Code

- $\quad$ Law No. 2014-344

Hungary:

- Government decree No 370/2004. (XII. 26.) on contracts negotiated away from business premises and on certain conditions of trading away from business premises

- Government decree nr. NGM/10342/4/2013 to amend the government decree 210/2009. (IX. 29.) on the conditions of conducting commercial activities

Slovakia:

Act of 29 October 2013, amending and supplementing Act no. 108/2000 Z. z. on Consumer Protection in Doorstep Selling and Mail Order Selling, as amended by later regulations, and supplementing Act no. 128/2002 Z. z. on State Supervision of Internal Market in Matters of Consumer Protection and amending and supplementing some acts, as amended by later regulations

United Kingdom:

House of Lords, European Union Committee, $18^{\text {th }}$ Report of Session 2008-09: Consumer Rights Directive: getting it right, Volume I: Report (Published by the Authority of the House of Lords, The Stationary Office Limited, London, 15 July 2009)

\section{Position Papers and Lobbying Material}

AVON Press Release, 'AVON withdraws from the US DSA', 12 September 2014, http://media.avoncompany. com/index.php?s=10922 (last visited 17 September 2014)

BEUC, The European Consumer Organization: Consumer Rights Directive adopted (1 October 2011) p. 1-2. http://www.beuc.org/publications/2011-09818-01-e.pdf (last visited 20 April 2015) 
BEUC, The European Consumer Organization: The Consumer Rights Directive - How to Get It Right Decision Makers' Guide (2010), p. 1-2. http://www.beuc.org/publications/2010-00534-01-e.pdf (last visited 20 April 2015)

BEUC, Unfair Commercial Practices - European Commission's questionnaire on the application of Directive 2005/29/EC - BEUC’s response; Ref.: X/2011/109 - 26 October 2011, http://www.beuc.org/publications/ 2011-09895-01-e.pdf (last visited 17 September 2014)

Direct Selling Europe (DSE), 'Proposal for a Directive on consumer rights (COM(2008)614 final)' 10 February 2011, http://www.directsellingeurope.eu/sites/default/files/DSE_issue_7.pdf (last visited 17 September 2014)

FEDSA: Commission Green Paper on policy options for progress towards European contract law for consumers and businesses (31 January 2011) p. 1-2. http://ec.europa.eu/justice/news/consulting_public/ 0052/contributions/143_en.pdf (last visited 20 April 2015)

FEDSA Response to the Green Paper on EU Consumer Protection COM (2001)531, 15 January 2002, final, http://ec.europa.eu/consumers/cons_int/safe_shop/fair_bus_pract/green_pap_comm/responses/business _europe/fedsa.pdf (last visited 17 September 2014)

FEDSA Position Paper on the revision of direct selling legislation in Europe, 16 May 2006, http://www.docstoc.com/docs/24461580/FEDSA-Position-Paper-on-the-revision-of-direct-sellinglegislation (last visited 17 September 2014)

FEDSA Press Release, 'Industry leaders call on MEPs to support 4 million Direct Sellers', 24 March 2011, http://www.seldia.eu/images/pdf/pr_6_23_03_2011.pdf (last visited on 17 September 2014)

FEDSA Response to the Discussion Paper on the Review on the Directive 85/577/EEC, 29 November 2007, http://ec.europa.eu/consumers/rights/docs/ds_resp_FEDSA.pdf (last visited 17 September 2014)

Recommendations by Direct Selling Sector on the proposed Consumer Rights Directive, September 2010, http://www.seldia.eu/sites/default/files/pdf-documents/pp-4-23-09-2010.pdf (last visited 17 September 2014)

Report on the application of Directive 2005/29/EC on Unfair Commercial Practices (UCPD) Questionnaire for Stakeholders, p. 5 http://www.seldia.eu/images/pdf/Seldia_response_UCPD_Questionnaire.pdf (last visited 17 September 2014)

Response of Direct Selling Europe (DSE) on the Discussion Paper on the Review of Directive 85/577/EEC to protect the consumer in respect of contracts negotiated away from business premises (Doorstep Selling Directive) of 3 December 2007, http://ec.europa.eu/consumers/archive/rights/docs/ds_resp_dse.pdf (last visited on 17 September 2014)

Response of the Italian Direct Selling Association, Avedisco to the Discussion Paper on the Review of Directive 85/577/EEC of 9 October 2007, http://ec.europa.eu/consumers/rights/docs/ds_resp_avedisco.pdf (last visited 17 September 2014)

Response of the Direct Selling Association (of the UK) to the Discussion Paper on the Review of Directive 85/577/EEC of 9 October 2007, http://ec.europa.eu/consumers/rights/docs/ds_resp_ukdsa.pdf (last visited 17 September 2014)

Seldia Press Release, 'European Parliament slams door in the face of millions of direct sellers', 2 February 2011, http://www.seldia.eu/images/pdf/pr_5_02_02_2011.pdf (last visited 17 September 2014)

Seldia: Response to the Consultation on the Implementation of the Unfair Commercial Practices Directive, 20 October 2011, http://www.seldia.eu/images/pdf/Seldia_response_UCPD_Questionnaire.pdf (last visited 17 September 2014)

Study prepared on behalf of the Federation of European Direct Selling Associations by Oppenheimer Wolff and Donnelly LLP with the support of Amway Corporation, Brussels, 16 March 1999 
Vorwerk's Response to the Discussion Paper on the Review of Directive 85/577/EEC, December 2007, http://ec.europa.eu/consumers/rights/docs/ds_resp_Vorwerk.pdf (last visited 17 September 2014)

World Federation Of Direct Selling Associations (WFDSA) Submission To Directorate A - Consumer Policy Health And Consumer Protection Directorate - General European Commission; Subject: Door to Door Selling - Pyramid Selling - Multilevel Marketing; Hearing 15 and 16 March 2000, http://www.wfdsa.org/ library/index.cfm?fa=pyramidselling (last visited 17 September 2014)

\section{Codes of Conduct}

Seldia’s Code of Conduct, http://www.seldia.eu/sites/default/files/uploads/content-pdf/seldia_codeofconduct.pdf (last visited 17 September 2014)

DSE's Code of Conduct, http://www.directsellingeurope.eu/sites/default/files/DSE_Code_of_Ethics.pdf (last visited 17 September 2014)

The World Code of Ethics can be found at the WFDSA website at http://www.wfdsa.org/files/worldcodes/code-book.pdf (last visited 17 September 2014)

Overview of the WFDSA Code of Ethics, available at http://www.wfdsa.org/world_codes/about-the-code/ (last visited 17 September 2014)

\section{Academic Literature}

Aldrich H.E. and Pfeffer J., 'Environments of Organisations', 2 Annual Review of Sociology, p. 79-105 (Volume publication date August 1976), p. 79-105.

Alter, K. and Vargas, J., 'Explaining Variation in the Use of European Litigation Strategies', 33 Comparative Political Studies, Number 4 (2000), p. 452-482.

Arregui, J., Stokman, F., and Thomson, R., 'Bargaining in the European Union and Shifts in Actors' Policy Positions', 5 European Union Politic, Issue 1 (2004), p. 47-72.

Babacan, M., 'The Nature of Lobbying and Regulation in Turkey', 1 Afro Eurasian Studies, Issue 1 (2012), p. 173-194.

Barnard C., The Substantive Law of The EU: The Four Freedoms ( $2^{\text {nd }}$ edition, Oxford University Press, Oxford, 2007)

Barnard, C., The Substantive Law of the EU: The Four Freedoms ( $4^{\text {th }}$ edition, Oxford University Press, Oxford, 2013)

Becker, G., 'Competition Among Pressure Groups', Vol. XCVIII The Quarterly Journal of Economics, No. 3 (1983), p. 371- 400.

Behrman, J. R., 'The Rise and Fall of Nations: Economic Growth, Stagflation and Social Rigidities by Mancur Olson', 9 Population and Development Review, No. 2 (June 1983), p. 377-379.

Ben-Shahar, O. and Posner, E. A., 'The Right to Withdraw in Contract Law', 40 Journal of Legal Studies, Issue 1, Article 4 (January 2011) p. 115-148.

Bentley, A. F., The Process of Government (University of Chicago Press, Chicago, IL, 1908)

Black, J. 'Decentring Regulation: Understanding the Role of Regulation and Self-Regulation in a 'PostRegulatory' World', 54 Current legal problems, Issue 1 (2001), p.103-146.

Bloch, B., 'Multilevel marketing: what's the catch?', 13 Journal of Consumer Marketing, Issue 4 (2006)

Bouwen P., 'Corporate lobbying in the European Union: towards a theory of access', 9 Journal of European Public Policy, Issue 3 (2002) p. 365-390.

Bouwen P., A Comparative Study of Business Lobbying in the European Parliament, the European Commission and the Council of Ministers, MPIfG Discussion Paper 02/7, ISSN 0944-2073, November 2002 
Bouwen, P., 'Exchanging access goods for access: A comparative study of business lobbying in the European Union institutions', 43 European Journal of Political Research, Issue 3, (2004), p, 337-369.

Bouwen, P. and McCown, M., 'Lobbying versus Litigation: Political and Legal Strategies of Interest Representation in the European Union, Empirical Studies of Interest Representation in the European Union', Special Issue of the Journal of European Public Policy, Working Paper 22, School of Public Policy, University College London, 20 January 2006

Bouwen, P. and McCown, M., 'Lobbying versus Litigation: Political and Legal Strategies of Interest Representation in the European Union, Empirical Studies of Interest Representation in the European Union', 14 Journal of European Public Policy, Issue 3 (2007), p. 422-443.

Braithwaite, J. 'Responsive Regulation in Australia', in Regulation and Australia's Future, edited by Grabosky, P. and Braithwaite, J., (Australian Institute of Criminology, Canberra, 1993)

Brodie et al., Public Perceptions of Direct Selling: An International Perspective, Westminster Business School Research Report 2004 (Westminster University Press, Westminster, 2004)

Buchanan, J. M., The Collected Works of James M. Buchanan in 20 vls. (Liberty Fund Inc., US, 1999)

Buchanan J. M. and Tullock G., The Calculus of Consent (Ann Arbor: University of Michigan Press, 1962)

Buchholz, R.A., Public policy issues for management (Prentice Hall, Englewood Cliffs, N.J., 1992)

Buholzer, R., Legislatives Lobbying in der Europäischen Union, Ein Konzept für Interessengruppen (Verlag Paul Haupt, Bern-Stuttgart-Wien, 1998)

Cafaggi, F., 'Self-regulation in European Contract Law', EUI Working Paper LAW No. 2006/43, Printed in Italy European University Institute, Badia Fiesolana (2006)

Cafaggi, F., 'Self-regulation in European Contract Law', 1 European Journal of Legal Studies, Issue 1, (2007)

Cauffman, C., 'The Consumer Rights Directive - Adopted', 19 Maastricht Journal of European and Comparative Law, 19(1), (2012), p. 212-218.

Collins, H., 'Harmonisation by Example: European Laws against Unfair Commercial Practices', 73 Modern Law Review Nr. 1, (2010), p. 89-118.

Cseres, K., Competition Law and Consumer Protection (Kluwer, The Hague, 2005)

Dobson, P., 'Does the ban on pyramid promotional schemes challenge the business model of a typical direct selling company?' 2 Journal of Business Law 2011, p. 194-207.

Downs, A., An Economic Theory of Democracy (Harper, New York, 1957)

Eidenmuller, H., 'Why Withdrawal Rights?', 7 European Review of Contract Law, Issue 1 (January 2011) p. 1-24.

Eisenberg, M.A., 'The bargain principle and its limits', 95 Harvard Law Review (1982)

Fairlie, R. W., 'Entrepreneurship, Economic Conditions, and the Great Recession', 22 Journal of Economics \& Management Strategy, Issue 2 (2013), p. 207-231.

Faure, M., 'Towards a maximum harmonisation of consumer contract law?', 4 Maastricht Journal of European and Comparative Law (2008)

Fleisher C., Brenner S., Burke L., Dodd-McCue D. and Rogers K., 'Managing the EU public policy environment: The role of North-American MNC's corporate public and government affairs function', 844 Viessmann discussion paper series on Europe, Waterloo, Ontario: European Research Group, Wilfred Laurier University (1993)

Fu Dai in 'A Model of Network Marketing Business Entrepreneurial Performance' Submitted to School of Management The University of Technology, Sydney in partial fulfilment of the requirements for the degree of Doctor of Philosophy, 2012, p.16., http://epress.lib.uts.edu.au/research/bitstream/handle/ 10453/20411/02Whole.pdf?sequence $=2$ (last visited 17 September 2014)

Gondor, M., 'A Common Corporate Tax Base In Order To Improve the European SMEs' Business Environment', 14 Juridical Current; Issue 1 (2011), p. 151-158. 
Gordon, K., 'Rules for the Global Economy: Synergies Between Voluntary and Binding Approaches', OECD Working Papers on International Investment, 1999/03, OECD Publishing, (1999), p. 6. http://dx.doi.org/10.1787/044824660786 (last visited 17 September 2014)

Goldring, J., Maher, L., McKeough, J., Pearson, G., Consumer Protection Law (5 ${ }^{\text {th }}$ edition, The Federation Press, Leichhardt, NSW., Australia, 1998)

Gouldson, A. and Murphy, J., Regulatory Realities: The Implementation and Impact of Industrial Environmental Regulation (Earthscan Publications, London, UK, 1998)

Green, D. and Shapiro, I., Pathologies of Rational Choice Theory: A Critique of Applications in Political Science, (Yale University Press, New Hampshire, 1994)

Greenwood, J. and Webster, R., 'Are EU Business Associations Governable?', 4 European Integration Online Papers, Number 3 (2000)

Greenwood, J., Grote J.R., Ronit K. (eds.), Organised interests and the European Community (Sage Communications, London, 1992)

Grilo, I. and Thurik, A. R., 'Entrepreneurship in the Old and New Europe', in Entrepreneurship, Growth, and Innovation: the Dynamics of Firms and Industries: International Studies in Entrepreneurship, Enrico Santarelli (ed.), (Springer Science, Berlin, 2006)

Gueguen; European Lobbying ( $2^{\text {nd }}$ edition, Europolitics, Brussels, 2007)

Gunningham, N. and Rees, J., 'Industry Self-Regulation - An Institutional Perspective', 19 Law \& Policy, Issue 4, October 1997, p. 363-414.

Haufler, V., A Public Role for the Private Sector: Industry Self-Regulation in a Global Economy (Carnegie Endowement for International Peace, Washington D.C., 2001)

Hesselink, M. W., 'Towards a Sharp Distinction between B2B and B2C? On Consumer, Commercial and General Contract Law after the Consumer Rights Directive', 18 European Review of Private Law, No. 18 (2010), p. 57-102.

Hill, J. P., 'Public Choice - A Review', 34 Faith \& Economics (1999) p. 1-10.

Hillmann, A. J., Hitt, M., 'Corporate political strategy formulation: a model of approach, participation and strategy decisions', 24 Academy of Management Review, Number 4 (1999), p. 825-842.

Hoeppner, S., 'The Unintended Consequence of Doorstep Consumer Protection: Surprise, Reciprocation, and Consistency', SSRN, SSRN-ID: 2057605, May 2012, http://papers.ssrn.com/sol3/papers.cfm?abstract_ id=2057605 (last visited 17 September 2014)

Hoskinson, R. and Hitt, M., 'Antescedents and performance outcomes of diversification: A review and critique of theoretical perspectives', 16 Journal of Management, p. 461-509.

Howells, G. 'The Scope of European Consumer Law', 3 European Review of Contract Law (2005)

Howells G., Micklitz H-W., Wilhelmsson T., European Fair Trading Law: The Unfair Commercial Practices Directive (Ashgate Publishing Ltd., Aldershot, England, 2006)

Johnson, M. A., Consumer Attitudes Toward Direct-to-Home Marketing Systems (Dunellen Publishing Company, New York, 1970)

Jolson, M. A., 'Direct Selling: Consumer vs. Salesman - Is Conflict Inevitable?', 15 Business Horizon, Issue 5 (October 1972)

Kelman, S., 'Public Choice’ and Public Spirit.', 87 The Public Interest (1987), p. 80-94.

Kerns, P., Fake It 'Til You Make It: What your soap distributor may not have told you (Victory Press, Carlton, Or.,1982)

Kingisepp, M., Värv, A., 'The Notion of Consumer in EU Consumer Acquis and the Consumer Rights Directive-a Significant Change of Paradigm?', 18 Juridica International (2011), p.44-53.

Kohler-Lettl, 'Das geltende europaische Lauterkeitsrecht, der Vorschlag fuer eine EG-Richtlinie ueber unlautere Geschaeftpraktiken und die UWG-Reform 2003' Wettbewerb in Recht und Praxis (2003) 
Kreppel, A. and Tsebelis, G., 'Coalition Formation in the European Parliament', 32 Comparative Political Studies (1999), p. 936-966.

Kuntze, R.J., The Dark Side of Multilevel Marketing Appeals to the Symbolically Incomplete, 2001, unpublished $\mathrm{PhD}$ dissertation, Arizona State University, Arizona as quoted by Fu Dai in 'A Model of Network Marketing Business Entrepreneurial Performance' Submitted to School of Management The University of Technology, Sydney in partial fulfilment of the requirements for the degree of Doctor of Philosophy, 2012, p.16., http://epress.lib.uts.edu.au/research/bitstream/handle/10453/20411/02Whole.pdf?sequence=2 (last visited 17 September 2014)

Lele M. M., Monopoly rules: How to Find, Capture, and Control the World's Most Lucrative Markets in any Business ((Paperback ed.), Kogan Page., London, 2007)

Letto-Vanamo, P; Smits, J.(eds.): Coherence and Fragmentation in European Private Law (Sellier European Law Publishers, Munchen, 2012)

Loos, M. B. M., 'Full harmonisation as a regulatory concept and its consequences for the national legal orders. The example of the Consumer rights directive', Centre for the Study of European Contract Law Working Paper Series No. 2010/03, available at http://papers.ssrn.com/sol3/papers.cfm?abstract_id=1639436 (last visited: 17 June 2015)

Lukes, S., Power: A Radical View (Macmillan Publishing, Basingstoke, 1974)

Mariano, J. and Brossi, M., 'Multilevel Marketing: A Legal Primer' (2nd Edition, Publisher: Direct Selling Association (US), Washington, 1997)

McChesney, F. S., 'Rent Seeking and Rent Extraction', in William,W. F. Shughart II and Razzolini, L. (eds.), The Elgar Companion to Public Choice (Edward Elgar, Cheltenham, UK, and Northampton, Massachusetts, USA, 2001), 379-395.

McCown, M., 'The European Parliament Before the Bench: ECJ Precedent and EP Litigation Strategies' 10 Journal of European Public Policy (2003) p. 974-995.

McCown, M., 'Rewriting the Treaties With Precedent: Intellectual Property Rights and EU Law'. Paper read at the European Union Studies Association Annual Conference. Nashville, TN. April 2003, as cited by Bouwen, P., and McCown, M., 'Lobbying versus litigation: political and legal strategies of interest representation in the European Union', 14 Journal of European Public Policy, Number 3 (2007), p. 422 - 443.

McCown, M., 'Interest Groups and the European Court of Justice', in: Coen, D. and Richardson, J. (eds.) Lobbying the European Union: Institutions, Actors, and Issues, chapter 5, (Oxford University Press, Oxford, 2009)

McKenzie, R. and Tullock, G., The New World of Economics: Explorations into the Human Experience (R.D. Irwin, Homewood, Illinois, 1981)

Micklitz, H-W., 'Aggressive Werbung' in Heermann, P. W. and Hirsch, G. (eds.), Munchener Kommentar zum Lauterkeitsrecht (C.H. Beck, Munchen, 2006), p. 904-984.

Micklitz, H-W., 'Do Consumer and Businesses Need a New Architecture of Consumer Law? A Thought Provoking Impulse', EUI Working Papers, Law 2012/23, Department of Law, available at http://papers.ssrn.com/sol3/papers.cfm?abstract_id=2169226 (last visited 17 June 2015)

Micklitz, H-W., Reich, N., Rott,P., Understanding EU Consumer Law (Intersentia, Antwerp - Oxford - Portland, 2009)

Micklitz, H. W., Reich, N., 'Crónica de una muerte anunciada: the Commission proposal for a "directive on consumer rights"', Common Market Law Review 2009, p. 474-475.

Micklitz H.-W., Stuyck J., and Terryn E., Cases, Materials and Text on Consumer Law (Hart Publishing, Oxford, 2010)

Nielsen, J. F. and Svendsen, G. T., 'EU Lobbying and Anti-Dumping Policy', 46 Journal of World Trade, No. 1 (2012) 
OECD, Open for Business; Migrant Entrepreneurship in OECD Countries, OECD Publishing, 2010, http://dx.doi.org/10.1787/9789264095830-en (last visited 17 September 2014)

Oksanen-Ylikoski, E., Businesswomen, Dabblers, Revivalists or Conmen? - Representation of Direct Selling and Salespeople within Academic, Network Marketing Practitioner and Media Discourses (Helsinki School of Economics A-269, HSE Print, Helsinki, 2006)

Olson, M., The Logic of Collective Action: Public Goods and the Theory of Groups (Harvard University Press, Cambridge, MA, 1965)

Olson, M., The Rise and Fall of Nations (Yale University Press, 1982)

Osuji, O. K., 'Business-to-consumer Harassment, Unfair Commercial Practices Directive and the UK - A Distorted Picture of Uniform Harmonisation?' 34 Journal of Consumer Policy, Number 4, Springer Publications (2011), p. 437-453.

Pappi, F. U., and C. H. C. A. Henning: 'The organisation of influence on the EC's common agricultural policy: A network approach', 36 European Journal of Political Research (1999), p. 257-281.

Pavillon, C.M.D.S., 'The Interplay between the Unfair Commercial Practices Directive and Codes of Conduct', 5 Erasmus Law Review, Issue 4 (2012), p. 267-288.

Peltzman, S., 'Toward a More General Theory of Regulation' 19 Journal of Law and Economics, No. 2 (1976), p. 211-240.

Pfeffer J. and Salancik G. R., The External Control of Organisations, A Resource Dependence Perspective (Harper and Row, New York,1978)

Piperopolous, P. G., Entrepreneurship, Innovation and Business Clusters (Gower Publishing Limited, Surrey, England, 2012)

Pollack, M. A., 'Rational Choice and EU Politics' in Jorgensen, K., Pollack, M. and Rosamond B. (eds.) Handbook of European Union Politics (p. 31-57.) (Sage Publications Ltd., London, 2006)

Posner, R. A., 'Theories of Economic Regulation', 5 Bell Journal of Economics and Management Science, No. 2 (1974), p. 335-358.

Reich, N., 'The Social, Political and Cultural Dimension of EU Private Law' in Schulze, R. and Schulte-Nolke, H. (Eds.), European Private Law - Current Status and Perspectives (Sellier European Law Publishers GmbH Munich, 2011) p. 57-89.

Research Group on the Existing EC Private Law, Contract II-Principles of the Existing EC Contract Law (Sellier, European Law Publishers, Munich, 2009)

Rott, P., 'Renationalisation of direct selling - the impact of the new Consumer Rights Directive on financial services', 13 ERA Forum (2012), p. 35-44.

Rott, P., Terryn, E., 'The proposal for a Directive on consumer rights: no single set of rules', 1 Zeitschrift für Europäisches Privatrecht (2009)

Rowley, C. K. and Schneider, F. (Eds.), The Encyclopedia of Public Choice (Kluwer Academic Publishers, Dordrecht, 2004)

Salisbury, R., 'Why No Corporatism in America?' in Schmitter, P.C., and Lehmbruch, G. (eds.), Trends Towards Corporatist Intermediation (Sage Publishing, London, 1979) p. 213-230.

Scharpf, F., Governing in Europe: effective and democratic? (Oxford University Press, Oxford, 1999)

Sen, A., 'Rational Fools, a critique of the behavioural foundations of economic theory', 6 Philosophy and Public Affairs, No. 4 (1977), p. 317-344.

Sinclair, D., 'Self-Regulation Versus Command and Control? Beyond False Dichotomies', 19 Law \& Policy, Issue 4 (1997) p. 529-559.

Smits, J. M., 'Full Harmonisation of Consumer Law? A Critique of the Draft Directive on Consumer Rights', 18 European Review of Private Law (2010), p. 5-14. 
Smits, J. M., 'Mixed Jurisdictions: Lesson for European Harmonisation?', 12 Electronic Journal of Comparative Law, Nr. 1 (2008)

Smits, J. M., 'Rethinking the Usefulness of Mandatory Rights of Withdrawal in Consumer Contract Law: The Right to Change Your Mind', 29 Penn St. Int'l L. Rev. 671 (2010-2011), p. 672-683.

Steennot, R., 'Are rules prohibiting the doorstep selling of certain goods and prohibiting the itinerant selling of goods and services without prior authorization compatible with the EU-Treaty and the Unfair Commercial Practices Directive?' - Universiteit Gent, Financial Law Institute, Working paper Series, WP 2013-04, August 2013, http://www.law.ugent.be/fli/wps/pdf/WP2013-04.pdf (last visited 17 September 2014)

Sternberg, R., 'Interregional Disparities, Entrepreneurship and EU Regional Policy', in The Dynamics of Entrepreneurship, Maria Minniti (ed.) (Oxford University Press, Oxford, 2011), p.153-181.

Stigler, G. J., The Citizen and the State (University of Chicago Press, Chicago, Il., 1975)

Strambeanu, G., Popovici, N., Moraru, C., 'Entrepreneurship: a Source of Economic Growth in EU', 6 EIRP Proceedings (2011), p. 698-705.

Stone Sweet, A. and Caparaso, J., 'From Free Trade to Supranational Polity; The European Court and European Integration' In Sandholz, Wayne and Alec Stone Sweet (ed.s) European Integration and Supranational Governance. (Oxford UP., Oxford, 1998)

Stone Sweet, A. and Brunell, T., 'Constructing a Supranational Constitution: Dispute Resolution and Governance in the European Community', 92 American Political Science Review (1999), p. 63-81.

Stone Sweet, A. and McCown, M., 'Free Movement of Goods in the European Union', In Alec Stone Sweet, ed., The Judicial Construction of Europe (Oxford University Press, Oxford, 2004)

Svendsen, G. T., 'Evaluating and Regulating the Impacts of Lobbying in the EU? The Case Study of Green Industries', 21 Environmental Policy and Governance, Issue 2 (2011), p. 131-142.

Svendsen, T. G., 'Lobbyism and Social Capital in the EU', 23 April 2007, ResearchGate, www.researchgate.net, p. 2. (last visited: 20 April 2015)

Tonner, K. and Tamm, M., 'Der Vorschlag einer Richtlinie über Rechte der Verbraucher und seine Auswirkungen auf das nationale Verbraucherrecht', JuristenZeitung 2009

Truman, D. B., The Governmental Process, $2^{\text {nd }}$ edition (Knopf, New York, NY, 1971)

Tullock, G.: 'Public Choice' in Durlauf, S. N. and Blume, L. E. (Eds.), The New Palgrave Dictionary of Economics, Second Edition, (Palgrave Macmillan, Basingstoke, Hampshire New York , 2008)

Tullock, G., 'The Welfare Costs of Tariffs, Monopolies, and Theft', 5 Western Economic Journal (1967)

Twigg-Flesner, C., European Union Private Law, (Cambridge, Cambridge University Press, 2010)

Twigg-Flesner, C., ',Good-Bye Harmonisation by Directives, Hello Cross-Border only Regulation?” - A way forward for EU Consumer Contract Law', 7 European Review of Contract Law, Issue 2, p. 235-256.

Unberath, H. and Johnston, A., 'The double-headed approach of the ECJ concerning consumer protection', Common Market Law Review 2007

VIEW Final Report (Micklitz-Monazzahian-Rossler): Door To Door Selling - Pyramid Selling - Multi Level Marketing Contract No. A0/7050/98/000156 A Study Commissioned By The European Commission - Final Report Volume I: Outline Of A Possible Approach To Regulation, November 1999, http://ec.europa.eu/consumers/cons_int/safe_shop/door_sell/sur10_01.pdf (last visited 17 September 2014)

Walker, J., Mobilizing interest groups in America (Ann Arbor: University of Michigan Press, 1991)

Weatherhill, S., 'After Keck: Some Thoughts on How to Clarify the Clarification', 33 Common Market Law Review, 1996, p. 885-906.

Weatherhill, S., EU Consumer Law and Policy (Elgar European Law, Cheltenham, UK - Northampton, MA, USA, 2005) 
Weatherill, S., 'The Consumer Rights Directive: How and why a quest for coherence has (largely) failed', 49 Common Market Law Review, (2012) p. 1279-1318.

Weschler, L. F., 'Public Choice: Methodological Individualism in Politics', 42 Public Administration Review, No. 3 (May- June 1982) Published by Wiley, p. 288-294

Weiler, J., H., The Constitution of Europe: „Do the new clothes have an emperor?” and Other Essays on European Integration (Cambridge University Press, Cambridge, 1999)

Wicklund, R.A. \& Gollwitzer, P.M., 'Symbolic self-completion, attempted influence, and self-deprecation', 2 Basic and Applied Social Psychology, Number 2. (1981), p. 89-114.

Wilhelmsson, T., 'Private Law in the EU: Harmonised or Fragmented Europeanisation?' 10 European Review of Private Law 77 (2002)

Yoffie D., 'Corporate strategies for Political Action' in Marcus, A.,A., Kaufman A.,M.,and Beam. D.,R. (eds.), Business strategy and public policy: Perspectives from business and academia (Quorum Books, New York, 1987) p. 43-60.

\section{Internet Sources}

Amway Global Entrepreneurship Report 2013, http://assets1.bywebtrain.com/501483/2013_amway_global_ entrepreneurship_report_1.pdf?r=1280 (last visited 17 September 2014)

Amquix, Amquix.info, 'Amquix explains pyramid schemes' http://www.amquix.info/quixtar_pyramid_ rebuttal.html (last visited 17 September 2014)

Babener, J. A, MLMLegal.com., 'The Landmark Amway Case', 1999, http://www.mlmlegal.com/landmark.html (last visited 17 September 2014)

Babener, J.A., MLMLegal.com, 'Pyramid: Yes or No?', 2001, http://www.mlmlegal.com/pyramidyn.html (last visited 17 September 2014)

Babener, J., MLMLegal.com, 'Direct Sales - An Overview - The Legal Environment', 2010 http://www.jdsupra. com/legalnews/direct-sales-an-overview-the-legal-env-95441/ (last visited 17 September 2014)

Babener, J., JDSupra Business Advisor, 'Direct Sales - An Overview - The Legal Environment', 2010, http://www.jdsupra.com/legalnews/direct-sales-an-overview-the-legal-env-95441/ (last visited $17 \mathrm{Sep}$ tember 2014)

Babener, J. A., MLMLegal.com, 'BurnLounge Appeal Decision:

Guidance on Pyramid v. Legitimate MLM and the Role of Personal Use in Pyramid Analysis', 2014, http://mlmlegal.com/Burnlounge\%20Appeal.html (last visited 17 September 2014)

Brady, H., Centre for European Reform, 'The EU's "yellow card" comes of age: Subsidiarity unbound?', 12 November 2013, http://www.cer.org.uk/insights/eus-yellow-card-comes-age-subsidiarity-unbound (last visited 17 September 2014)

Clements, L., 'Ponzi \& Pyramid', MarketWave (2009), http://www.marketwaveinc.com/viewarticle.asp?id=72 (last visited 17 September 2014)

Davidson, N., ExplosiveMLM.com, 'The Amway Law Suits Explained', 4 November 2010, http://explosive $\mathrm{mlm} . c 0 m / a m w a y / a m w a y-l a w s u i t s-e x p l a i n e d /$ (last visited 17 September 2014)

DG Justice's website on Misleading Advertising, available at http://ec.europa.eu/justice/consumermarketing/unfair-trade/false-advertising/index_en.htm (last visited 17 September 2014)

Direct Selling Europe's website: http://www.directsellingeurope.eu/ (last visited 17 September 2014)

Direct Selling News, Global Ranking - published on 8 April 2015; available at http://directsellingnews.com/ index.php/view/2015_dsn_global_100_list\#.VWwpTM9Viko (last visited 1 June 2015) 
Direct Selling Europe Proposal for a Directive on consumer rights, 10 February 2011 http://www.directsellingeurope.eu/sites/default/files/DSE_issue_7.pdf last visited 17 September 2014)

Direct Selling News, 2013 DSN Global 100 List, on 3 April 2013; http://directsellingnews.com/index. php/view/2013_dsn_global_100_list\#.Uzl7ofmSxpA (last visited 17 September 2014)

EurActiv.com, 'Re-inventing Europe's entrepreneurial spirit', 28 May 2013, available at http://www.euractiv.com/innovation-enterprise/reinventing-europe-entrepreneuri-analysis-528098 (last visited 17 September 2014)

European Commission's website, Evaluation of the Commercial Agents Directive, http://ec.europa.eu/internal_market/qualifications/other_directives/commercial_agents/index_en.htm (last visited 17 September 2014)

European Shopping Centre Trust: Key European Retail Data - 2012 review and 2013 forecast (April 2013) http://www.deutsche-

euroshop.de/media/public/db/media/1/2011/12/199/201305_esct_key_european_retail_data.pdf (last visited 17 September 2014)

FAO Corporate Document Repository, General Sampling Considerations http://www.fao.org/ docrep/004/y2790e/y2790e05.htm (last visited 17 June 2015)

Federal Bureau of Investigation: Common Fraud Schemes, FBI website: http://www.fbi.gov/scamssafety/fraud/fraud\#pyramid (last visited 17 September 2014)

Federal Trade Commission Press Release, FTC Action Leads to Court Order Shutting Down Pyramid Scam Thousands of Consumers Burned by BurnLounge, 14 March 2012, http://www.ftc.gov/news-events/pressreleases/2012/03/ftc-action-leads-court-order-shutting-down-pyramid-scamthousands (last visited 17 September)

Franco, A., 'The entrepreneurial gap between men and women' (30/2007), 2007, http://epp.eurostat.ec.europa. eu/cache/ITY_OFFPUB/KS-SF-07-030/EN/KS-SF-07-030-EN.PDF (last visited 17 September 2014)

Greenberg, H., TheStreet, 'What to Expect from Herbalife Probe', 13 March 2014, http://www.thestreet.com/ story/12528628/1/greenberg-what-to-expect-from-herbalife-probe.html (last visited 17 September 2014)

Grimes, K., D., MLMLaw.com, 'Income and Earnings Representations 1996-2003', http://www.mlmlaw.com/ library/guides/IncomeClaims.pdf (last visited 17 September 2014)

Gullo, K., Bloomberg, 'BurnLounge Ruling in FTC Case Seen as Good for Herbalife', 3 June 2013, http://www.bloomberg.com/news/2014-06-02/burnlounge-shutdown-by-ftc-upheld-by-federal-appealscourt-1-.html (last visited 17 September 2014)

Jacobs, E., Financial Times, 'Ambitious migrants fuel rise in direct selling', 5 April 2013, http://www.ft.com/intl/cms/s/0/c0176c2e-9dfc-11e2-9ccc-00144feabdc0.html\#axzz2t34mmXAf (last visited 17 September 2014)

KPMG India: Direct Selling - A global industry empowering millions in India, 2012, available at https://www.kpmg.com/IN/en/IssuesAndInsights/ArticlesPublications/Documents/Direct-Selling.pdf (last visited on 7 July 2015)

Laggos, K., 'Matrices and illegal pyramid schemes', Network Marketing Business Journal, December 2010 Issue, http://www.nmbj.com/articles/archives/PubsPer/PP_December_2010.asp (last visited 17 September 2014)

Lawrence Graham LLP: 'Amway defeats legal challenge in the UK', 16 May 2008, http://www.docstoc. com/docs/87964902/Sales-Management-Practice-of-Amway

Network Marketing Business School, 'Is Network Marketing a Pyramid Scheme?', http://www.networkmarketing-business-school.com/pyramid-scheme.html (last visited 17 September 2014)

Ozmorali, H., The World of Direct Selling, 'Wisdom in 100 Words: Personal Consumption', 9 June 2014, http://www.worldofdirectselling.com/100-words-personal-consumption/ (last visited 17 September 2014) 
Patelou,, V., H+K's views on comitology: letter to the editor of Europolitics, 9 February 2012, http://www.hkstrategies.be/news/hk\%E2\%80\%99s-views-comitology-letter-editor-europolitics (last visited 17 September 2014)

Seldia's Annual Report of 2010-2011, http://www.seldia.eu/images/pdf/SELDIA\%20Annual\%20Report \%202011-2012.pdf (last visited 17 September 2014)

Seldia, 'Representing direct selling in Europe', Annual Report 2012-2013, http://www.seldia.eu/images/pdf/ SELDIA_AR_2013.pdf (last visited 17 September 2014)

Seldia's website: http://www.seldia.eu/ (last visited 17 September 2014)

Stevenson, A. and Eavis, P., The New York Times, FTC inquiry into Herbalife Prompts Big Share Selloff, 12 March 2014, http://dealbook.nytimes.com/2014/03/12/herbalife-discloses-f-t-c-inquiry/?_php=true\&_ type $=$ blogs\&_php=true\&_type=blogs\&_php=true\&_type=blogs\&_r=2\& (last visited 17 September 2014)

The Economist, 'A Commission Report Card', 24 September 2009, http://www.economist.com/node/ 14505501 (last visited 17 June 2015)

Thompson, K., Scribd, 'Pyramid Schemes: Saving the network marketing industry by defining the gray' (July 2009), http://www.scribd.com/doc/13639323/Pyramid-Schemes-Saving-the-network-marketing-industryby-defining-the-gray (last visited 17 September 2014)

Thompson, K., MLMHelpdesk.com, 'Legitimate MLM or Pyramid Scheme: How can you tell?' (July 2009), http://mlmhelpdesk.com/wp-content/Docs/Direct_Selling/MLM_Attorney_Kevin_Thompson_PyramidSchemes-Saving-the-network-marketing-industry-by-defining-the-gray.pdf (last visited 17 September 2014)

Thompson, K., 'Self-Deception: a cancer holding the MLM industry back', The MLMAttorney, 9 April 2012, http://thompsonburton.com/mlmattorney/2012/04/09/self-deception-a-cancer-holding-the-mlmindustry-back/ (last visited 17 September 2014)

Thompson, K., Direct Selling News Blog, 'The BurnLounge Court Decision Clears the Air on Many Issues', 5 August 2014, http://dsnblog.com/tag/pyramid-scheme/ (last visited 17 September 2014)

Thompson, K., MLMAttorney - Videoblog, 'Avon Writes Open Letter to DSA Members Regarding Its Decision to Leave', 16 September 2014, http://thompsonburton.com/mlmattorney/2014/09/16/avon-writesopen-letter-to-dsa-members-regarding-its-decision-to-leave/ (last visited 17 September 2014)

Thress, K. C., Gibbons Law P.C., 'Comparative advertising in the European Union', 18 November 2011, http://www.gibbonslaw.com/news_publications/articles.php?action=display_publication\&publication_id $=3569$ (last visited on 17 September 2014)

Weber, C., Associated Press, 'A lawsuit accusing Herbalife of being a pyramid scheme has been dismissed, 19 March 2015, http://uk.businessinsider.com/the-lawsuit-accusing-herbalife-of-being-a-pyramid-schemehas-been-dismissed-2015-3?r=US (last visited 16 June 2015)

Wikipedia, 'Direct Selling Association', http://en.wikipedia.org/wiki/Direct_Selling_Association (last visited 20 May 2015)

Wikipedia, 'Public Choice', http://en.wikipedia.org/wiki/Public_choice (last visited 20 April 2015)

WEP website, http://womenentrepreneurshipplatform.eu/about-us/supported-by-seldia/ (last visited 17 September 2014)

World Federation of Direct Selling Associations' website: http://www.wfdsa.org/ (last visited 17 September 2014) 


\section{Interviews and Questionnaires}

\section{(Interview transcripts and questionnaire responses are on file with the author)}

Interview with public affairs manager of "SweetScent Cosmetics" on 27 June 2012 (phone interview).

Interview with public affairs manager of "SuperFit" on 6 July 2012.

Interview with Mr. Paul Gagnier on 23 August 2012 (phone interview).

Interview with Mr. Oscar Cano Arias on 29 May 2013 and 28 October 2013 (the latter was a follow-up interview) in Brussels.

Interview with Mrs. Marie Lacroix on 20 May 2013 in Brussels.

Interview with Mr. Hakki Ozmorali on 30 September 2013 in Brussels.

Interview with Mr. Simon Levitt on 22 October 2013 in Brussels.

Interview with Janne Heimonen, Managing Director of Kyani Europe Inc. on 31 October 2013 in Brussels.

Interview with Mr. Maurits Bruggink on 2 December 2013 in Brussels.

Interview with consultant of "Pinkify" on 17 December 2013 in Brussels.

11 Responses to the 'Questionnaire for Direct Selling Associations on Direct Selling Industry Lobbying in The

European Union' (Questionnaire form in Annex II) 


\section{Curriculum Vitae}

Orsolya Tokaji-Nagy (1980) holds a Master's degree in Political Sciences (Eotvos Lorand University, Budapest, Hungary) and in European Law (Maastricht University, the Netherlands). Having started her career as an independent political analyst, writing articles for English-speaking publications in Hungary, Orsolya later gained years of experience in European consumer law and advocacy in the framework of the European Consumer Centre's Network as well as in the largest Hungarian consumer organisation, the National Association for Consumer Protection in Hungary. Thereafter she was invited by the direct selling industry to spearhead the sector's lobbying in Hungary as the secretary-general of the national trade association. Subsequently she worked for the largest direct selling company's Brussels office, Amway Europe, representing the industry's interests towards European legislators and other key stakeholders. Having started her $\mathrm{PhD}$ as an external researcher at the Maastricht University in early 2013, Orsolya completed her dissertation in the summer of 2015. She now lives and works in Dublin, Ireland. 
